UNIVERSIDADE DE SÃO PAULO

INSTITUTO DE GEOCIÊNCIAS

\title{
PLANÍCIES DE INUNDAÇÃO FLUVIAIS PRÉ-VEGETAÇÃO: EXEMPLOS DO SUPERGRUPO ESPINHAÇO (MESOPROTEROZOICO, BA) E DO SUPERGRUPO CAMAQUÃ (EDIACARANO - CAMBRIANO, RS)
}

\author{
André Marconato \\ Orientador: Prof. Dr. Renato Paes de Almeida \\ TESE DE DOUTORAMENTO \\ Programa de Pós-Graduação em Geoquímica e Geotectônica
}

São Paulo 


\section{PLANÍCIES DE INUNDAÇÃO FLUVIAIS PRÉ-VEGETAÇÃO: EXEMPLOS DO SUPERGRUPO ESPINHAÇO (MESOPROTEROZOICO, BA) E DO SUPERGRUPO CAMAQUÃ (EDIACARANO - CAMBRIANO, RS)}

Tese apresentada ao Instituto de Geociências da Universidade de São Paulo para obtenção de título de Doutor em Geologia.

Área de concentração: Geotectônica

Orientador: Prof. Dr. Renato Paes de Almeida

São Paulo 
MARCONATO, A. Planícies de inundação fluviais pré-vegetação: exemplos do Supergrupo Espinhaço (Mesoproterozoico, BA) e Supergrupo Camaquã (Ediacarano - Cambriano, RS) Tese [Doutorado]: Instituto de Geociências da Universidade de São Paulo. São Paulo: 2014. 114 p..

\section{Resumo}

Planícies de inundação são áreas sujeitas a fluxo episódico de água, que devido a disponibilidade de água, nutrientes e substrato estável, foram largamente afetadas desde o surgimento e subsequente evolução de plantas vasculares terrestres. Neste contexto, a escassez de exemplos documentados de planícies de inundação formadas anteriormente ao período Siluriano contrasta com décadas de debate acerca dos efeitos da evolução de plantas terrestres em estilos de canais fluviais. Dada a importância de planícies de inundação como sítios de acumulação de partículas sedimentares, intemperismo de minerais silicáticos e desenvolvimento de perfis de solo, esta falta de dados sobre planícies de inundação antigas tem importante impacto na forma como entendemos sistemas transporte de sedimento, o registro climático e ciclos geoquímicos globais do Precambriano e início do Paleozoico. Com o objetivo de aprimorar os modelos existentes de planícies de inundação pré-vegetação, desenvolvidos antes da evolução de plantas vasculares no continente, três exemplos de ambientes aluviais foram investigados com o emprego de análise de fácies e de elementos arquiteturais. Os exemplos escolhidos oferecem a oportunidade de avaliar não apenas a existência destes depósitos sedimentares, mas também de propor um modelo para a deposição deste ambiente sedimentar particular. A Formação Tombador (Supergrupo Espinhaço, BA) é parte de espessa sucessão sedimentar de idade Mesoproterozoica, que inclui depósitos aluviais e costeiros; O Grupo Santa Bárbara e o Grupo Guaritas (Supergrupo Camaquã, RS), que se estendem do fim do Neoproterozoico ao início do Cambriano, representam sucessões aluvias depositadas em rift continental. O estudo destes três exemplos permitiu a determinação de possíveis feições comuns a planícies de inundação pré-vegetação, como depósitos de granulação relativamente mais grossa em comparação a exemplos modernos, melhor preservação de estruturas sedimentares e abundância de facies arenosas representativas de condições de fluxo e sedimentação desconfinadas. Os exemplos de planícies de inundação pré-vegetação utilizadas para compor este modelo simplificado compartilham de semelhanças marcantes a depósitos de rios efêmeros, que são frequentemente citados como explicação para a formação de espessos depósitos de arenitos-em-lençól. A reavaliação de depósitos fluviais pré-vegetação, considerando a possibilidade de que planícies de inundação de granulação grossa, sugere que este ambiente deposicional tem sido bastante negligenciado, e que inferências climáticas obtidas da alternância de estilos fluviais contrastantes pode ser equivocada, uma vez que a alternância de registro de rios perenes e efêmeros podem ser parte de um mesmo sistema deposicional.

Palavras-chave: Planície de inundação, sistemas fluviais, pré-vegetação, Cambriano, Ediacarano, Mesoproterozoico. 
MARCONATO, A. Pre-vegetation fluvial floodplains: examples from the Espinhaço Supergroup (Mesoproterozoic, Northeastern Brazil) and Camaquã Supergroup (Ediacaran Cambrian, Southern Brazil) Thesis [Doctorate]: Institute of Geosciences, University of São Paulo. São Paulo: 2014. 114p..

\begin{abstract}
Floodplains are areas of unconfined and episodic water flow that, given the generalized availability of water, nutrients and stable substrate, have been extensively affected by the first appearance and subsequent evolution of land plants. In this respect, the scarcity of documented examples of pre-Silurian floodplain deposits contrasts with the continuous and decades-long debate on the effects of land plants evolution on fluvial channel styles. Given the importance of floodplains as sites of sediment storage, silicate minerals weathering and development of soil profiles, this lack of data on ancient floodplains has great implications for our understanding of the source-to-sink systems, the climate record and the global geochemical cycles of the Precambrian and the Early Paleozoic. Aiming at the improvement of the current models regarding pre-vegetation floodplains, which were developed prior to the evolution of vascular land plants, three examples of alluvial environments were investigated trough facies and architectural elements analysis. The used examples offer the opportunity to assess not only the existence of such deposits, but also to propose a model for the deposition of those particular sedimentary environments. The Mesoproterozoic Tombador Formation (Espinhaço Supergroup, Northeastern Brazil) is part of thick sedimentary deposits, which includes alluvial and coastal environments; the Neoproterozoic Santa Bárbara Group and the Cambrian Guaritas Group (Camaquã Basin, Southern Brazil) represents alluvial successions deposited in a continental rift system. The study of the three examples allowed the determination of some common features to pre-vegetation floodplain deposits, like relatively coarser grained deposits in comparison to modern examples, better preservation of sedimentary structures and abundance of sandstone facies representative of sedimentation in unconfined flow settings. The pre-vegetation floodplain deposits used to draw this simplified model share characteristics remarkably similar to ephemeral river deposits, which are frequently evoked to explain the formation of thick successions of sheet-like sandstone deposits. The re-evaluation of pre-vegetation fluvial deposits considering the possibility of coarse grained floodplains suggests that this environment have been greatly overlooked, and that climate inferred from the alternation of contrasting fluvial styles might be misleading, since alternation of deposits representing perennial and ephemeral fluvial deposits can be part of the same depositional system.
\end{abstract}

Keywords: Floodplains, Fluvial systems, pre-vegetation, Cambrian, Ediacaran, Mesoproterozoic. 


\section{Índice}

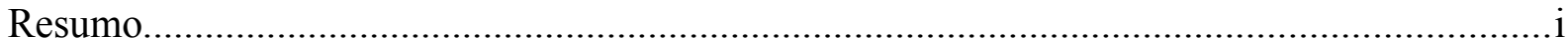

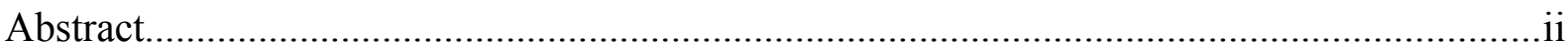

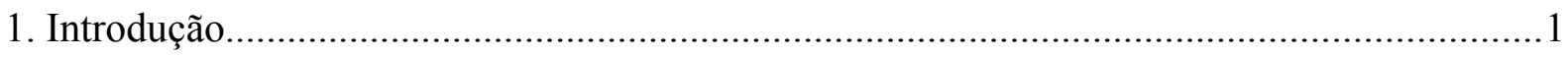

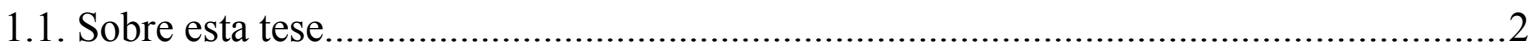

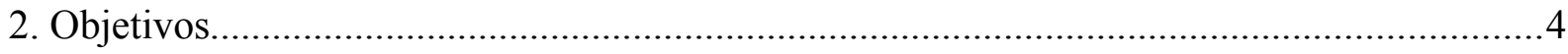

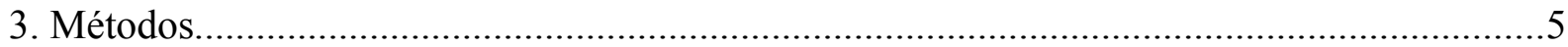

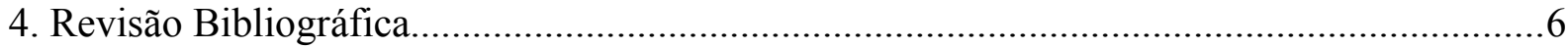

4.1. Planícies de inundação, planícies pré-vegetação e paleossolos em planícies

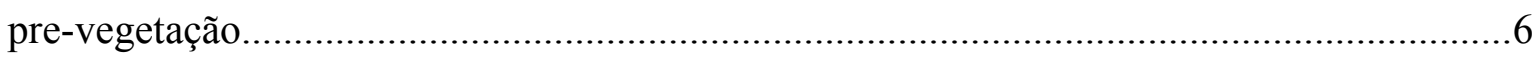

4.1.1. Geometria das planícies de inundação................................................................

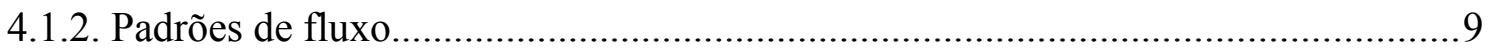

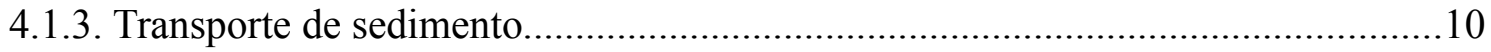

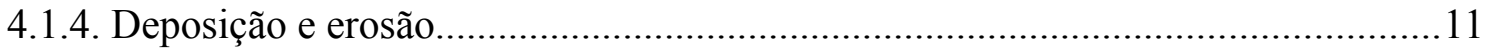

4.1.5. Depósitos sedimentares em planícies de inundação.............................................12

4.1.6. Planícies de inundação pré-vegetação................................................................. 17

4.1.7. Paleossolos no Proterozoico e início do Paleozoico..............................................21

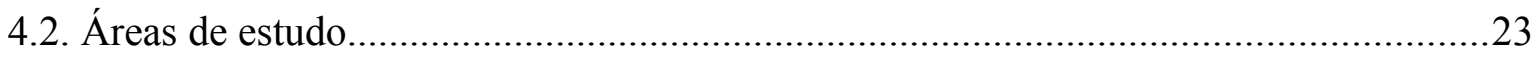

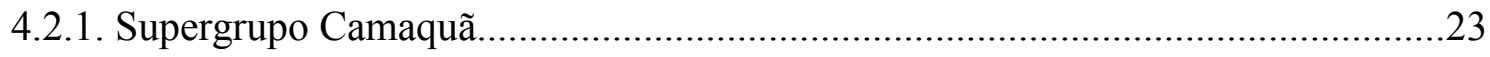

4.2.1. Supergrupo Espinhaço na Chapada Diamantina..................................................28

5. Pre-vegetation fluvial floodplains and channel-belts in the late Neoproterozoic-Cambrian

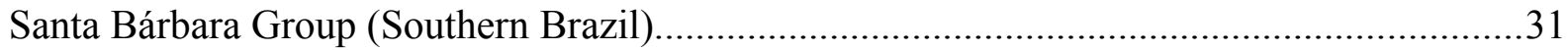

6. Floodplain record in the early Cambrian Varzinha Formation (Southern Brazil): channelized and unconfined flow in the absence of vegetation..............................................44

7. Deposition and preservation of fine grained facies in a Mesoproterozoic river system: the case of the Tombador Formation, Northeastern Brazil....................................................... 78

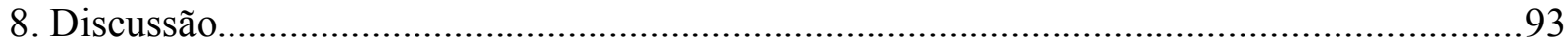

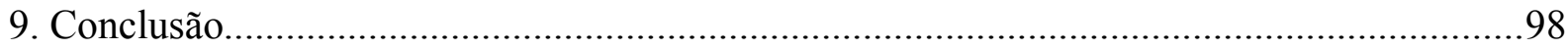

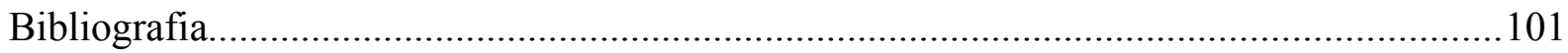


Assinatura:

Data:

Catalogação na Publicação (CIP)

Serviço de Biblioteca e Documentação

Instituto de Geociências da Universidade de São Paulo

\section{Marconato, André}

Planícies de inundação fluviais pré-vegetação: exemplos do Supergrupo Espinhaço (Mesoproterozoico, BA) e Supergrupo Camaquã (Ediacarano - Cambriano, RS)./André Marconato. São Paulo: 2014. 114p..

Tese (Doutorado): Instituto de Geociências da Universidade de São Paulo Orientador: Prof. Dr. Renato Paes de Almeida

1. Planície de inundação. 2. Sistemas fluviais. 3. pré-vegetação. 4. Cambriano. 5. Ediacarano. 6. Mesoproterozoico. I. Título. 
Nome: André Marconato

Título: Planícies de inundação fluviais pré-vegetação: exemplos do Supergrupo Espinhaço (Mesoproterozoico, BA) e Supergrupo Camaquã (Ediacarano - Cambriano, RS).

Tese apresentada ao Instituto de Geociências da Universidade de São Paulo para obtenção do título de Doutor em Geologia

Área de concentração: Geotectônica

Aprovado em:

Prof. Dr.: Instituição:

Julgamento: Assinatura:

Prof. Dr.: Instituição:

Julgamento: Assinatura:

Prof. Dr.: Instituição:

Julgamento: Assinatura:

Prof. Dr.: Instituição:

Julgamento: Assinatura:

Prof. Dr.: Instituição:

Julgamento: Assinatura: 


\section{Agradecimentos}

Uma jornada tão longa quanto um projeto de doutorado, por mais que leve em destaque o nome do candidato, não pode ser visto como construto de um indivíduo, mas sim como resultado das experiências que obteve junto à rede de colaboração em que esteve inserido ao longo de sua jornada pelo início da vida acadêmica. Infelizmente falho em enumerar todas as pessoas que colaboraram para a realização deste projeto, mas, ainda assim, saibam que sou muito grato a todos que de alguma forma me ajudaram nesta jornada.

Em particular, gostaria de começar agradecendo ao meu Orientador, Prof. Dr. Renato Paes de Almeida, por toda sua dedicação à realização deste projeto, desde a sua idealização até os últimos instantes da finalização do projeto, que de forma entusiasmada, não só incentivou, mas também garantiu todas as condições para que a realização deste projeto fosse possível. Agradeço à Profa. Dra. Liliane Janikian Paes de Almeida e ao Prof. Dr. Renato Paes de Almeida pela oportunidade de participar como colaborador de projetos de pesquisa em nome de ambos, fundamentais para a execução deste projeto, assim como agradeço a generosidade com a qual sempre receberam a mim em sua casa, quando tratávamos, entre generosas refeições, de assuntos que sempre se estendiam para além da pesquisa científica.

À Fundação de Amparo a Pesquisa do Estado de São Paulo (FAPESP) agradeço pelo apoio institucional na forma projetos de pesquisa e bolsas de estudo (09/53362-1, 11/50280-4, 13/01825-3, 10/51103-6, 13/02114-3), assim como sou grato à Coordenadoria de Aperfeiçoamento de Ensino Superior - CAPES (PROEX-558/2011) pela bolsa de estudo concedida através do Programa de Geoquímmica e Geotectônica do Igc-USP.

Sou imensamente grato a amigos do IGc, Cristiano P. Galeazzi, E. Donald Ngonge, Fernanda Quaglio, Lucas V. Warren, Vinícius T. Meira, pela camaradagem no dia-a-dia da geologia, e em agradeço especialmente a Bernardo T. Freitas, Bruno B. Turra, Felipe T. Figueiredo, Simone C. Carrera, amigos que colaboraram com sugestões, críticas, e toda a camaradagem em atividades de campo e viagem a conferências.

Sou grato aos professores Cláudio Riccomini e Ivo Karmann pelas sugestões enriquecedoras à minha qualificação, assim como agradeço os professores Lucy G. Sant'Anna e Antônio Romalino S. Fragoso-Cesar pela colaboração em atividades de campo.

Agradeço ao Prof. Gregory J. Retallack pela supervisão e todo o apoio em meu intercâmbio na University of Oregon. Sou muito grato aos estudantes de pós-graduação da UO, em especial John Jacisin, Win McLaughlin e Ryan Seward, pela hospitalidade e companheirismo.

Agradeço ao corpo de funcionários dos IGc, em especial ao pessoal da secretaria de Pós-Graduação, Magali P.F. Rizzo, Leonardo J. Capucci, Katherine K. Hummel e Tadeu, e ao pessoal da gráfica, Claudionor e Henrique.

Á meus pais, Agostinho e Regina, agradeço o apoio e incentivo ao longo de toda minha formação acadêmica. A meu irmão, Heitor, agradeço pelas conversas descontraídas. A Juvenal e Cleuza agradeço o apoio e generosidade ao longo destes anos.

Por fim, sou imensamente grato à minha esposa, Jussara, por toda ajuda, incentivo, e principalmente, pela paciência dedicada a seu eterno "estudo de caso" ao longo destes anos, sendo sempre meu porto seguro, mesmo durante as piores tempestades. 


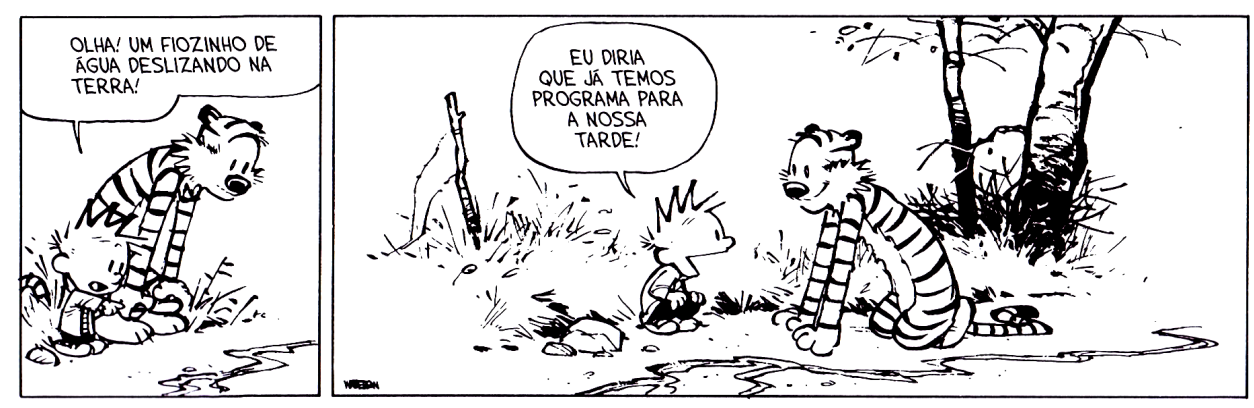




\section{Introdução}

Planícies de inundação compõem parte essencial dos sistemas aluviais, sejam eles modernos ou antigos. Sua importância se estende além da que é reconhecida na sedimentologia e na estratigrafia, constituindo sítios preferenciais para a instalação humana desde a antiguidade até os dias de hoje, tanto em atividades de lavoura como na própria instalação de moradias, visto que boa parte dos grandes centros urbanos atuais são desenvolvidos em planícies de inundação fluvial.

Apesar destes aspectos, o estudo de planícies de inundação, sejam modernas ou antigas, é relativamente pouco desenvolvido, especialmente se comparado ao volume de estudos dedicados aos depósitos desenvolvidos nos cinturões de canais. Dessa forma, a organização espacial de planícies de inundação, padrões de fluxo, processos de erosão e deposição, entre outros aspectos, são pouco compreendidos (Bridge, 2003), sendo que boa parte do conhecimento sobre processos sedimentares em planícies de inundação são derivados de modelos experimentais. Parte da justificativa para a escassez de estudos de planícies de inundação reside no fato de a maior parte dos depósitos estarem áreas de ação antrópica, em maior ou menor grau. $\mathrm{O}$ mesmo não pode ser dito dos depósitos sedimentares antigos, mas seu estudo tem sido preterido devido ao potencial econômico - considerado pouco expressivo - se comparado aos depósitos arenosos de cinturão de canais, que frequentemente funcionam como reservatórios de hidrocarbonetos, além de abrigarem concentrações minerais específicas.

Entretanto, planícies de inundação compõem importantes sítios para estudos paleoclimáticos, especialmente pelo desenvolvimento de paleossolos, que podem fornecer informações valiosas a respeito do regime pluviométrico, sazonalidade de estações, entre outras informações. Outro aspecto do estudo de planícies de inundação é a sua utilização na construção de modelos de preenchimento de bacias, sendo que sua ocorrência é frequentemente associada ao aumento da taxa de geração de espaço de acomodação de uma bacia sedimentar, ao desenvolvimento de perfis de equilíbrio pouco inclinados em sistemas aluviais, assim como ao estabelecimento de condições agradacionais durante o preenchimento de determinado intervalo estratigráfico. Este aspecto do estudo de depósitos de planícies de inundação torna crucial a melhor compreensão de seus processos sedimentares e de sua relação com outros sistemas deposicionais, pois, neste contexto, a variação lateral entre diferentes ambientes da planície aluvial e sua sobreposição por migração lateral dos sistemas pode resultar em interpretações equivocadas sobre as variações temporais nos controles sobre 
a deposição.

Outro aspecto importante do estudo de planícies de inundação trata da evolução da vida na história geológica e como isso afetou o desenvolvimento e organização destes depósitos sedimentares. Como as planícies de inundação constituem partes do sistema deposicional mais sujeitas ao povoamento por vegetação e animais, é de se esperar que a progressiva transformação destes ambientes em nichos ecológicos tenha tido impacto significativo na arquitetura dos depósitos sedimentares, da mesma maneira como sugerido para sistemas de cinturão de canais ao longo do Paleozoico (Davies \& Gibling, 2011). Além do impacto da colonização e evolução da cobertura vegetal sobre planícies de inundação, estas constituem alvos preferenciais para investigação de formas de vida primordiais no continente, devido à disponibilidade de umidade e de nutrientes minerais, assim como a relativa estabilidade do substrato. Além disso, a maior proporção de partículas finas e menor tendência a criação de superfícies erosivas permitem o registro de estruturas delicadas que podem indicar atividade biológica, como wrinkle marks, além de possíveis indicadores biogeoquímicos.

Neste cenário, questões importantes envolvendo a natureza das planícies de inundação formadas antes do surgimento de plantas vasculares em ambientes continentais ainda precisam ser respondidas, como: Qual seriam suas principais fácies sedimentares? Existem feições características ou particulares que permitam uma identificação positiva de depósitos de planície? A identificação do contexto em que depósitos de planície de inundação se encontram inseridos é importante para sua identificação? Planícies de inundação pré-vegetação são diversas, ou compõem um estilo de depósito particular?

\subsection{Sobre esta tese}

O presente estudo está organizado em uma seção de embasamento teórico sobre o estudo de planícies de inundação, na qual se enumeram os métodos utilizados e é detalhada uma revisão sobre a bibliografia existente para este tipo de ambiente deposicional. A revisão contempla tanto os processos quanto os depósitos de planícies de inundação antigas e modernas, de maneira a oferecer um embasamento teórico dos processos sedimentares mais importantes e característicos, assim como as principais características reconhecidas nos depósitos desde o Paleozoico. Com base nessa revisão, é realizada comparação com os depósitos anteriores à colonização do continente por plantas com raízes, documentados de forma escassa na literatura. Tais trabalhos, que identificam e descrevem depósitos sedimentares interpretados como planícies de inundação anteriores ao estabelecimento da 
vegetação continental, são então abordados em revisão detalhada. Por fim, são apresentadas revisões sobre a evolução do conhecimento sobre as áreas de estudo, de maneira a oferecer o contexto geológico para os depósitos estudados.

Com o intuito inicial de ampliar a base de conhecimento existente sobre planícies de inundação pré-vegetação, foram escolhidas áreas de estudo que a um só tempo permitissem o registro e detalhamento das características deste tipo de depósito, como também permitissem o registro de sua variabilidade. Com base em reconhecimento preliminar prévio ao início dos trabalhos, foram enfocadas sucessões da Bacia do Camaquã (centro-sul do estado do Rio Grande do Sul), pertencentes aos grupos Santa Bárbara e Guaritas, e sucessões do Supergrupo Espinhaço, na região da Chapada Diamantina, pertencentes à Formação Tombador, que registra depósitos aluviais desenvolvidos durante o Mesoproterozoico.

Os resultados obtidos são apresentados na seção seguinte na forma de artigos, sendo dois destes manuscritos em preparação para submissão e um já publicado no periódico Sedimentary Geology. Cada um dos artigos compõem um capítulo desta tese, representando as três unidades abordadas ao longo da execução do presente projeto doutoramento

- O primeiro artigo, de título "Pre-vegetation fluvial floodplains and channel-belts in the Late Neoproterozoic-Cambrian Santa Bárbara Group (Southern Brazil)", já publicado, versa sobre depósitos sedimentares do Supergrupo Camaquã, de idade Ediacarana a Cambriana, em sucessões siliciclásticas do Grupo Santa Bárbara. O estudo tem como motivação a construção de um modelo de sistema deposicional que explique a relação entre depósitos de planície de inundação pré-vegetação e outros ambientes sedimentares dentro da planície aluvial, como o cinturão de canais e leques aluviais.

- O segundo artigo, "Floodplain record in the Early Cambrian Varzinha Formation (Southern Brazil): channelized and unconfined flow in the absence of vegetation", em preparação, é focado em depósitos Cambrianos do Supergrupo Camaquã, com o objeto de estudo na Formação Varzinha, dentro do Grupo Guaritas. A motivação principal deste estudo foi a contextualização e interpretação de abundantes sucessões de arenitos de fluxo desconfinado associadas a depósitos de canais e depósitos ricos em fácies de decantação. 
- $\mathrm{O}$ terceiro artigo, "Deposition and preservation of fine grained facies in a Mesoproterozoic river system: the case of the Tombador Formation, Northeastern Brazil.", em preparação, versa sobre depósitos aluviais de idade Mesoproterozoica do Supergrupo Espinhaço na região da Chapada Diamantina, nos quais encontram-se espessas sucessões arenosas da Formação Tombador. Parte da sucessão sedimentar pode ser interpretada como depositada em ambientes fluviais, e se encontra intercalada a redbeds de granulação mais fina, com feições de exposição subaérea e fácies que indicam deposição em condições distintas daquelas tradicionalmente descritas em depósitos fluviais pré-cambrianos.

Desta forma, a presente tese pretende colaborar para o desenvolvimento do conhecimento acerca da variabilidade de sistemas deposicionais desenvolvidos no pré-cambriano e início do Paleozoico, assim como colaborar para a compreensão das particularidades dos sistemas deposicionais aluviais anteriores ao surgimento da vegetação continental.

\section{Objetivos}

Para responder às questões norteadoras apresentadas no item 1., um conjunto de objetivos foi determinado, de maneira a aproveitar da melhor forma possível a possibilidade de respostas que poderiam ser obtidas nas áreas de estudo escolhidas.

O primeiro objetivo envolve caracterizar os depósitos de planícies de inundação pré-vegetação, incluindo a compilação e informações de exemplos descritos na literatura, ainda que escassos, confrontados a exemplos ainda não estudados de forma a se obter um quadro mais claro das características gerais desses depósitos..

O objetivo seguinte envolve determinar semelhanças e diferenças entre planícies de inundação pré-vegetação e exemplos modernos, influenciados pela colonização por plantas vasculares. A exploração desta questão compreende a comparação de características de fácies sedimentares e geometrias de corpos sedimentares.

A relação das planícies de inundação com diferentes partes do sistema fluvial, como o cinturão de canais, figura como o terceiro objetivo da tese, pois o reconhecimento de planícies de inundação como parte integrante de ambiente deposicional aluvial implica na necessidade de compreensão de seu posicionamento relativo a outros ambientes do mesmo sistema.

Um quarto objetivo importante envolve a determinação dos modos de preservação dos 
depósitos pelíticos nos sistemas fluviais pré-vegetação, sua formas de ocorrência, e as situações em que a deposição e preservação de fácies pelíticas é desfavorecida.

\section{Métodos}

A abordagem adotada para o estudo dos depósitos sedimentares baseia-se na análise de fácies combinada à análise de elementos arquiteturais, aplicadas de maneira semelhante à descrita por Reading (1986), Walker $(1992,2006)$ e Miall (1990, 2000). Desta forma entende-se que a análise de fácies compreende o estudo e a interpretação de texturas, estruturas sedimentares, fósseis e associações litológicas de rochas sedimentares em escala de afloramentos, testemunhos de sondagem ou pequenas porções de uma bacia. A análise de fácies consiste no agrupamento de litotipos com estruturas semelhantes ou outras feições características representativas de processos particulares, para que através da classificação possa-se compreender a relação entre os vários tipos de depósitos e reconstituir as características dos ambientes deposicionais.

No presente trabalho evitou-se a aplicação direta de codificações de fácies preestabelecidas, estabelecendo-se classificações baseadas na descrição de campo e adequadas a cada caso, de forma a refletir a variabilidade real e caraterizar mais precisamente os depósitos abordados, mesmo que disso decorra menor facilidade de leitura por parte de pesquisadores familiarizados com a codificação padrão (e.g., Bridge, 1993). Da mesma forma, os elementos arquiteturais descritos não foram diretamente correlacionados aos propostos na bibliografia (e.g., Miall, 1990, 2014), evitando-se a codificação e a atribuição de escalas temporais supostas para cada hierarquia de superfícies limitantes.

Medições sistemáticas da atitude de estratos cruzados, limites de séries e superfícies de maior hierarquia foram realizadas com o objetivo de realizar reconstituições de padrões de paleofluxo e de geometria tridimensional dos corpos de sedimento e seus padrões de acréscimo em relação à paleocorrente (ver revisão em Miall, 1990, 2014).

Métodos adicionais utilizados pontualmente em estudos específicos são descritos nos artigos que compõem esta tese. 


\section{Revisão Bibliográfica}

\subsection{Planícies de inundação, planícies pré-vegetação e paleossolos em planícies pre-vegetação \\ Planícies de inundação historicamente têm recebido menos atenção no}

desenvolvimento de modelos de fácies em comparação aos depósitos de cinturões de canais fluviais, em parte devido a modelos consagrados apresentados em livros-texto que apresentam planícies como resultantes simplesmente da dinâmica de sistemas de canais (ver discussão em North \& Davidson, 2012). Entretanto, a partir da década de 90 tais ambientes passaram a receber mais atenção da comunidade científica, principalmente pelo crescente interesse no estudo de paleossolos e de dados para estudos de mudanças climáticas (Miall, 1996). Neste contexto seus depósitos são entendidos como produtos de processos sedimentares além-canal, seja acrescionados a partir do cinturão de canais, seja em acumulação dentro da própria planície (Nanson \& Croke, 1992; Aslan \& Autin, 1999).

Planícies de inundação compõem um ambiente sedimentar complexo, associado a canais fluviais, muitas vezes difícil de se delinear ou definir. Uma definição relativamente ampla e que satisfaça a pesquisadores com diferentes abordagens sobre o tema pode ser obtida a partir das propostas de Schmnudde (1968), Alexander \& Marriott (1999) e Bridge (2003). De acordo com os autores, uma planície de inundação pode ser definida como uma faixa de terreno adjacente a um canal fluvial principal, com relevo topograficamente pouco expressivo, formada por sedimento transportado pelo rio ao qual está relacionada, ou por processos autóctones (como formação de solos ou de depósitos gerados por atividade biológica), e que é inundado durante enchentes sazonais, seja pelo fluxo de água oriundo do canal principal, de chuva intensa, fluxo superficial vindo dos flancos do vale aluvial, ou uma combinação destes. Bridge (2003) afirma categoricamente que planícies de inundação são formadas independentemente do padrão de canal do sistema aluvial, seja entrelaçado ou meandrante, e que podem se desenvolver também lateralmente a leques aluviais e a deltas. Tal assertiva tem respaldo na literatura recente, visto que há descrições de planícies de inundação lamosas laterais a canais entrelaçados (Bentham et al., 1993), além de planícies de inundação de granulação grossa (Alexander \& Fielding, 2006) e planícies desenvolvidas antes do desenvolvimento da vegetação continental (Fralick \& Zaniewski, 2012), demonstrando casos que fogem aos modelos consagrados, desenvolvidos para sistemas fluviais meandrantes (e.g., Miall, 1978; Orton \& Reading, 1993; Collinson, 1996). 


\subsubsection{Geometria das planícies de inundação}

De maneira simplificada, as características principais de uma planície de inundação são mostradas na Figura 4.1. Embora a topografia seja relativamente pouco expressiva, Bridge (2003) e (Bridge \& Demicco, 2008) dividem a planície de inundação em cristas aluviais (alluvial ridges), alguns decímetros a poucos metros mais altas que a área adjacente, a bacia de inundação (floodbasin). Estas cristas aluviais podem ser tanto ativas quanto abandonadas, e compreendem tanto canais e barras ativos e inativos, diques marginais (levees), canais de

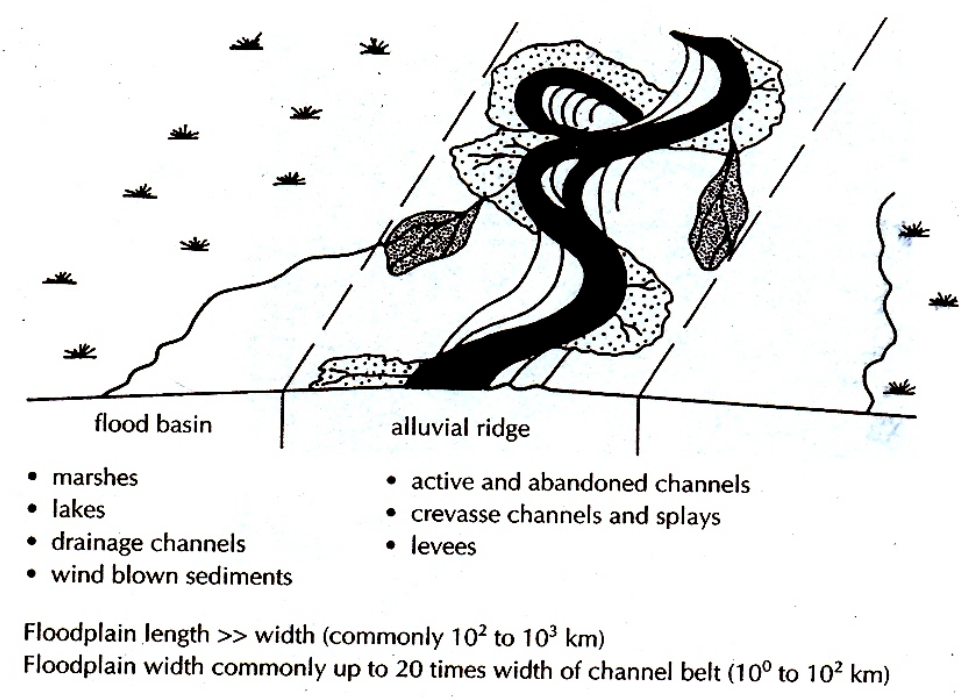

Fig. 4.1: Principais elementos de planícies de de inundação. (Bridge, 2003).

crevasse (crevasse channels) e depósitos de rompimento de diques marginais (crevasse splays) (Bridge 2003), sendo assim as áreas da planície de inundação sujeitas à influência do aporte sedimentar do canal principal. Diques marginais são seguimentos elevados e descontínuos, em forma de cunha, e que ocorrem imediatamente ao lado de canais (Brierley et al., 1997), com alguns metros de altura, e extensão até quatro vezes superior à do canal associado (Cazanacli \& Smith, 1998). Localmente podem ser atravessados por canais de rompimento de diques marginais (crevasse channels), que desembocam em lobos de rompimento de diques marginais, organizados geralmente em corpos com centenas de metros até quilômetros de largura (Smith \& Perez-Arlucea, 1994; Bristow et al., 1999). Podem terminar distalmente com gradual perda de espessura (O’Brien \& Wells, 1986), abruptamente, em ângulo de repouso (Bristow et al. 1999) ou na forma de deltas, quando atingem pequenos lagos (Miall, 1996). Canais de rompimento de diques marginais podem continuar a se desenvolver sobre os lobos, e podem desenvolver sua própria crista aluvial, com diques marginais e depósitos de rompimento menores associados (Fielding, 1986; Bridge \& 
Demicco, 2008). Estes canais são descritos por Bridge (2003) como sendo efêmeros, ativos apenas durante a enchente, embora exista a possibilidade de que tais canais possam evoluir para distributários do canal principal (Fielding, 1986).

De acordo com Bridge (2003) e Bridge \& Demicco (2008), a área mais baixa da planície de inundação, a bacia de inundação, tem forma em geral mais longa que larga, acompanhado o sentido do vale aluvial, e pode ser segmentada por cristas aluviais menores ou por depósitos de rompimento de diques marginais. Sobre essa área é comum e existência de canais de drenagem (e.g., Fielding 1986), e de acordo com o regime climático podem ser encontrados lagos perenes ou efêmeros. Embora em depósitos modernos a vegetação possa colonizar praticamente qualquer porção da planície aluvial, é nesta área que seu efeito é mais importante, e onde podem ter maior impacto sobre a sedimentação (e.g., Alexander \& Marriott, 1999), visto que podem aumentar a coesão de partículas sedimentares e oferecer obstáculos ao fluxo de água, protegendo a superfície de erosão. Outros mecanismos, entretanto, podem ser propostos para explicar o aumento de coesão de partículas sedimentares, como simples aumento da proporção de partículas finas, ou cimentação precoce devido às particularidades climáticas (e.g., Wilson et al., 2014). Em ambientes áridos ou com
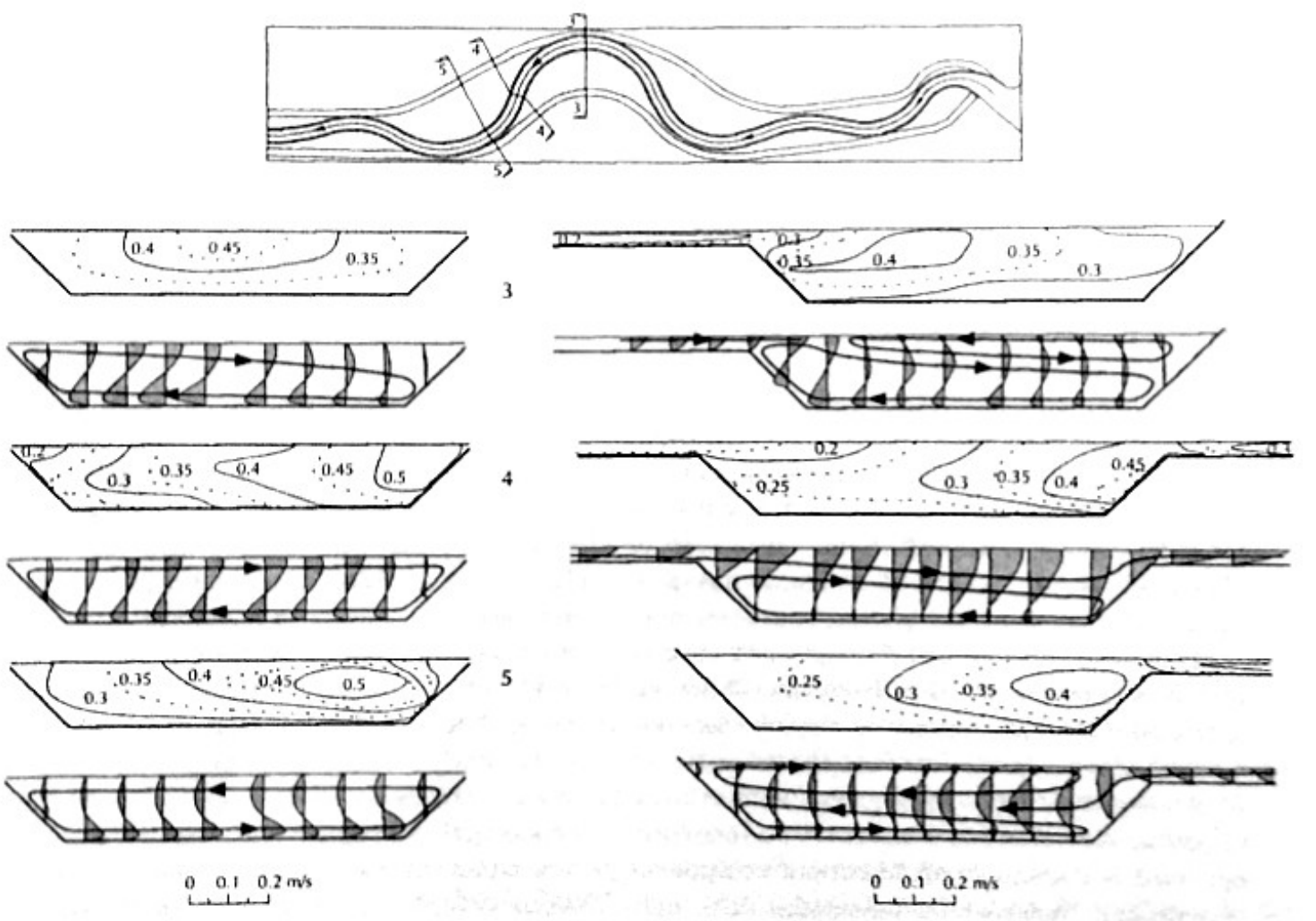

Fig. 4.2: Padrões de fluxo em diferentes fases em experimento de enchente. Notar a queda de velocidade dentro do canal quando o fluxo transborda para a área correspondente a planície de inundação, além da mudança no padrão de fluxo. Extraído de Naish \& Sellin (1996). 
ausência de cobertura vegetal pode haver retrabalhamento eólico, com formação de dunas (e.g., (Sønderholm \& Tirsgaard, 1998), assim como feições de ressecamento e de formação de solos (Bown \& Kraus, 1987).

\subsubsection{Padrões de fluxo}

A despeito da relativa baixa amplitude do relevo das planícies de inundação, a

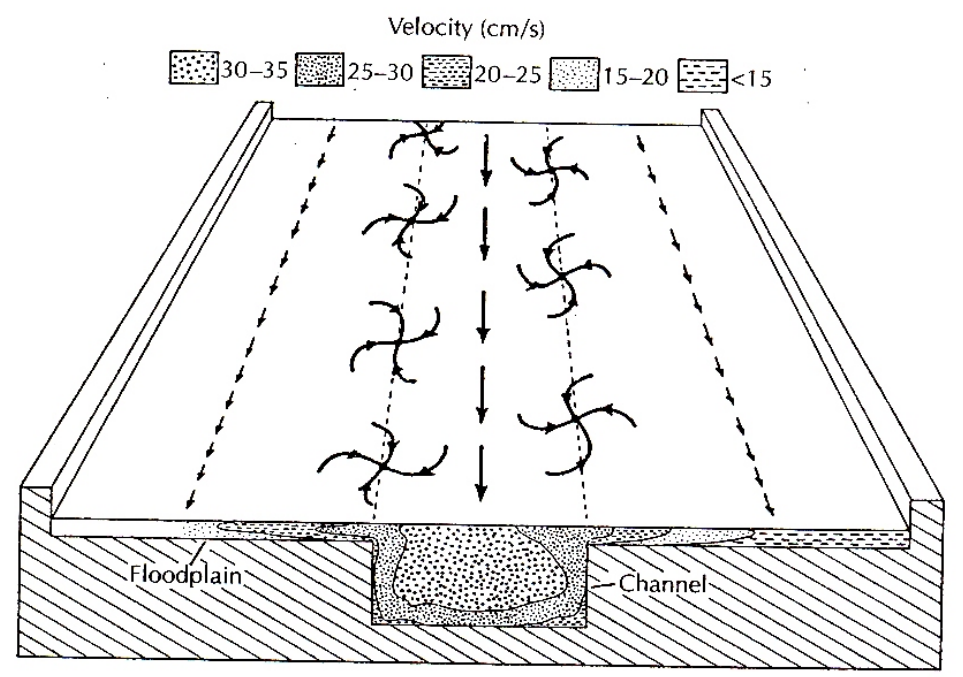

Fig. 4.3: Padrão de fluxo durante enchente em experimento em escala. Notar diminuição da velocidade para as bordas, e formação de redemoinhos na superfície para acomodar a diminuição de velocidade. Extraído de Bridge (2003).

variedade de geometrias, com a presença de cristas aluviais, canais abandonados e lobos de depósitos de rompimento de diques marginais, por exemplo, implica em um relevo que pode trazer grande complexidade à determinação de padrões de fluxo em uma planície de inundação, especialmente no que tange à sua observação e quantificação (Hughes \& Lewin, 1982; Nicholas \& Mclelland, 1999). Por esse motivo, grande parte do conhecimento de padrões de fluxo em planícies de inundação é baseado em modelos experimentais (e.g., Knight \& Brown, 2001; Myers et al., 2001; Valentine et al., 2001), que apresentam uma relação bastante simplificada entre canal e planície de inundação, sem considerar transporte de sedimento (Fig. 4.2).

Tais modelos determinam que o fluxo mais rápido em uma enchente ocorre no canal, com progressiva diminuição de velocidade das bordas do canal para a planície (Allen, 1970) (Fig. 4.3). Neste contexto o maior gradiente de velocidade (e portanto maior potencial de deposição) está na transição entre o canal e a planície de inundação, sendo que o gradiente de queda da velocidade do fluxo é maior quanto mais rasa for a coluna de água sobre a 


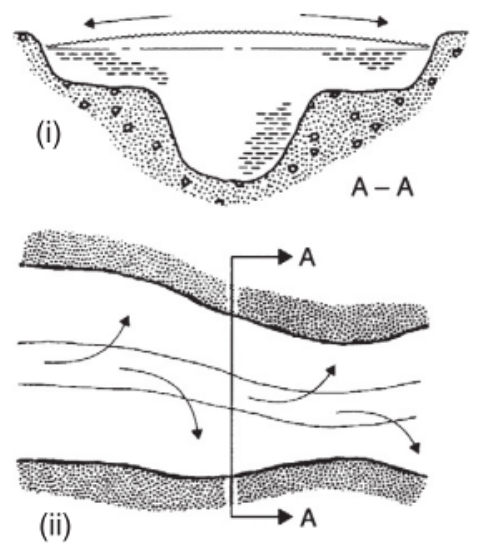

(ii)
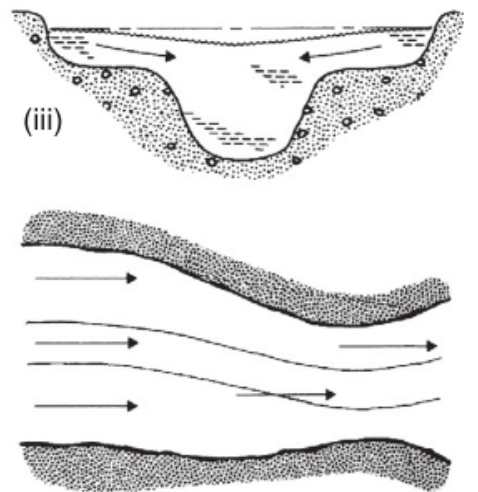

(iv)

Fig. 4.4: Mudanças de direção de fluxo durante cheia além do canal. (i) Seção e (ii) visão em planta de um canal durante o início da enchente; (iii) seção mostrando o fluxo retornando ao canal acompanhando a queda da descarga; (iv) visão em planta mostrando fluxo a jusante unidirecional, cruzando o canal submerso, durante cheia da enchente (North \& Davidson, 2012).

planície (Wormleaton, 1996). Outro aspecto importante observado em experimentos (Naish \& Sellin, 1996) é a queda da velocidade do fluxo dentro do canal quando a enchente invade a planície de inundação (overbank flow), em relação à velocidade durante a cheia do canal (bankfull flow) (Fig. 4.2), o que pode implicar em aumento da sedimentação dentro do canal forçada por queda na capacidade de transporte do fluxo.

Embora o entendimento dos padrões de fluxo em planícies de inundação seja ainda muito precário (Bridge \& Demicco, 2008), Bridge (2003) propõe um modelo simplificado e hipotético de um evento de enchente: durante o aumento do fluxo (rising flow stage) a água invade a planície através de canais de crevasse, diques marginais baixos e pelo fluxo vindo das encostas do vale aluvial, e neste momento, como o nível de água no canal cheio está mais alto que a planície, o fluxo adentra a planície de inundação acelerando, e portanto tende a ser erosivo; No pico do fluxo (peak flow) o vale todo se torna uma corrente única fluindo aproximadamente para jusante do vale aluvial, com maior velocidade de fluxo nas áreas correspondentes a canais e redemoinhos na transição para o fluxo mais lento da planície de inundação; durante a diminuição do fluxo (falling flow stage) a água flui de volta para o canal principal (Fig. 4.4), seja por sobre diques marginais menos desenvolvidos, seja por meio de canais de drenagem, e há a formação de corpos lacustres, que podem secar ou não de acordo com variantes como regime climático e nível do lençol freático.

\subsubsection{Transporte de sedimento}

Partículas sedimentares chegam à planície de inundação principalmente por canais principais e tributários, embora o aporte vindo da encosta do vale aluvial e partículas geradas 
na própria planície também ocorram. São transportados tanto carga de fundo quanto material em suspensão (Bridge 2003). Apesar do entendimento geral de que sedimentos gerados na própria planície de inundação sejam finos, existe um conjunto de partículas que pode alcançar a granulação de areia até seixo, na forma de agregados de lama (Muller et al., 2004; Wright \& Marriott, 2007), concreções pedogênicas e detritos orgânicos, como ossos, conchas e restos vegetais (e.g., (Fielding, 1986; Bown \& Kraus, 1987). A partir do canal principal, o sedimento é carregado tanto em fluxos canalizados quanto em fluxos desconfinados (Bridge, 2003; North \& Davidson, 2012), com a geração de formas de leitos, principalmente ôndulas (ripples), e leitos planos, embora dunas possam se formar em canais mais profundos e antidunas possam se formar em fluxo muito raso e rápido (Bridge \& Demicco, 2008). North \& Davidson (2012) são enfáticos em afirmar que fluxos desconfinados respondem pela maior parte do transporte e sedimentação na planície de inundação, e sugerem que a variedade de processos e produtos de fluxos desconfinados são maiores do que usualmente assumido na literatura em sedimentologia.

\subsubsection{Deposição e erosão}

Como a maior desaceleração do fluxo durante uma enchente ocorre junto às bordas dos canais (Wormleaton, 1996), é esperado que a maior taxa de sedimentação ocorra em diques marginais e depósitos de rompimento de diques marginais, contribuindo para a sobrelevação da crista aluvial em relação à bacia de inundação (Tornqvist, 1993; Gomez et al., 1995; Allison et al., 1998). Baixos topográficos, como canais abandonados e corpos lacustres, também podem provocar queda na velocidade do fluxo e consequentemente ter taxas de sedimentação relativamente mais altas, a não ser quando tais depressões canalizam o fluxo de água, o que pode provocar aceleração do fluxo e até mesmo erosão (Bridge, 2003). As menores taxas de sedimentação estarão concentradas nas bacias de inundação mais distantes dos canais ou em altos topográficos da bacia (Bridge \& Demicco, 2008), embora ocasionalmente enchentes de maior magnitude possam cobrir porções distais de bacias de inundação com uma camada de sedimento relativamente mais grosso (Bridge \& Demicco, 2008). A não ser por locais com taxa de sedimentação excepcionalmente alta, a deposição na bacia de inundação durante as maiores enchentes sazonais varia de milímetros a centímetros de espessura (Asselman \& Middelkoop, 1995; Middelkoop \& Asselman, 1998; Walling \& He, 1998; Bridge, 2003). Apesar da queda na taxa de sedimentação das bordas do canal para a bacia de inundação, especialmente da de carga de fundo, a taxa de sedimentação pode ser relativamente uniforme para toda a bacia de inundação, uma vez que é dominada por 
sedimentação de material em suspensão (Bridge \& Demicco, 2008).

Aceleração de fluxo e consequente erosão na planície de inundação ocorrem de maneira localizada em trechos canalizados ou onde há convergência de fluxo (Bridge, 2003). Outras áreas podem estar sujeitas a erosão durante uma enchente, como altos topográficos na planície ou áreas pobres em cobertura vegetal (Bridge, 2003). Outros fatores de modificação da planície são resultado de retrabalhamento eólico de trechos da planície de inundação, do crescimento de vegetação, que embora possa retardar processos erosivos, pode causar obliteração do registro de estruturas sedimentares, assim como de atividade animal (Bridge \& Demicco, 2008). Outros aspectos de modificação da planície de inundação envolvem o ressecamento de depósitos particularmente ricos em lama, assim como variados graus de pedogênese (Retallack, 1986, 2001; Kraus, 1987).

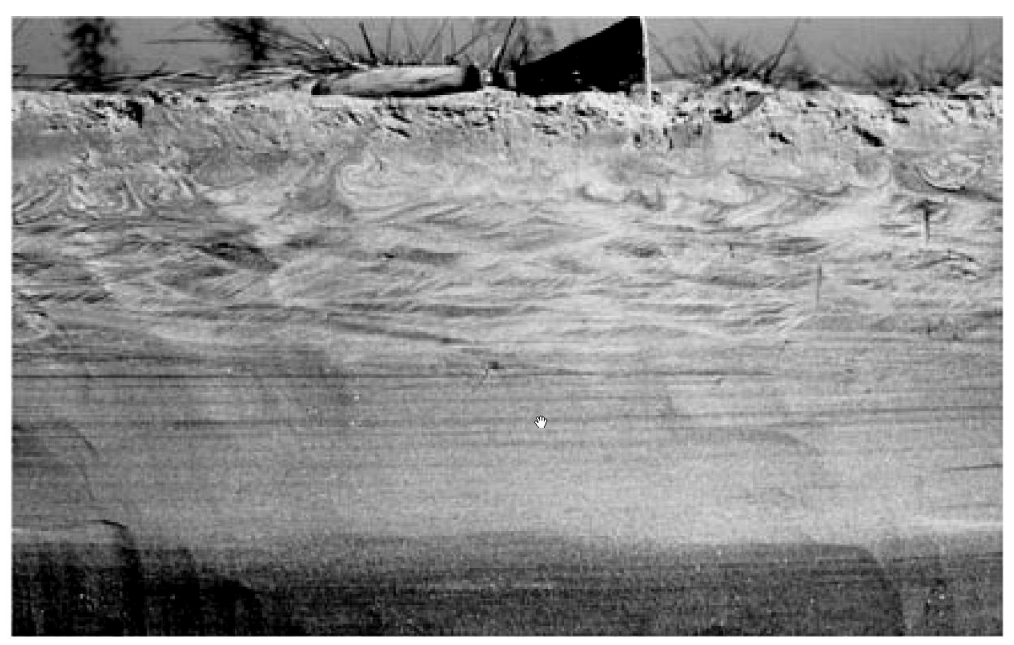

Fig. 4.5: Exemplo de sucessão de fácies encontrada em depósitos de diques marginais, que apresentam arenitos laminados que passam para arenitos com laminação cruzada cavalgante no topo. Notar estruturas de deformação de sedimento inconsolidado (Bridge \& Demicco, 2008).

\subsubsection{Depósitos sedimentares em planícies de inundação}

De maneira geral, os depósitos de planícies de inundação são divididos em quatro elementos arquiteturais (Miall, 1996), ou simplesmente depósitos (Bridge, 2003) de diques marginais (levees), canais de rompimento de diques marginais (crevasse channels), depósitos desconfinados de rompimento de diques marginais (crevasse splays) e bacia de inundação (floodplain basin), ou finos de planícies de inundação (floodplain fines). Dependendo das particularidades dos depósitos estudados ou do enfoque dos autores, descrições de elementos adicionais, como preenchimentos de canais abandonados, depósitos de carvão e depósitos de fluxos desconfinados (unconfined flow), por exemplo, podem ser encontrados com menor 


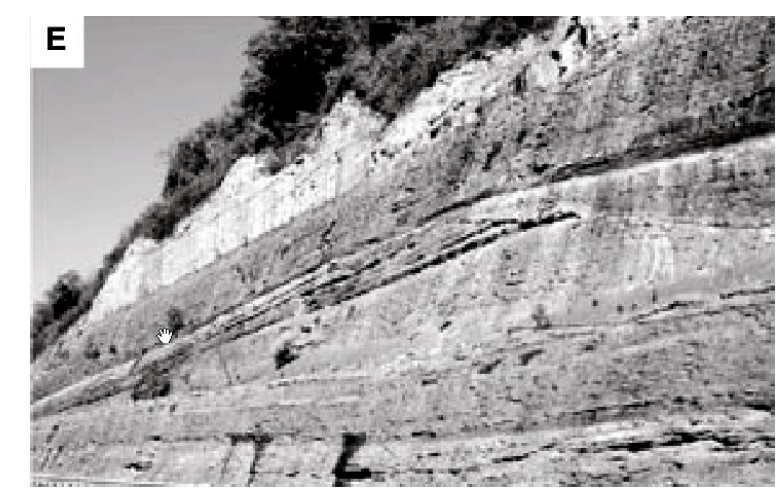

Fig. 4.6: Canal de rompimento de dique marginal (lado direito da foto) cortando lobos de rompimento de dique s marginais (Bridge \& Demicco, 2008).

frequência em artigos relacionados ao tema, assim como descrições detalhadas de paleossolos.

Os depósitos de diques marginais são compostos em geral por areia fina siltosa, com laminação cruzada relacionada a migração de pequenas formas de leito, frequentemente com alguma bioturbação (Bown \& Kraus, 1987; Smith \& Perez-Arlucea, 1994). Bridge (2003) descreve os depósitos como semelhantes aos depósitos finos de topo de barras, com arenitos com laminação plano-paralela na base, cobertos por depósitos com estratos cruzados de pequena escala, que podem ter recobrimento de lama, também descritos por Fielding (1986). Frequentemente a laminação é convoluta (Bridge, 2003). Paleocorrentes das marcas onduladas e laminação cruzada são paralelas ou oblíquas ao fluxo do canal principal (Fielding, 1986; Miall, 1996). Embora sejam prontamente relacionados a rios meandrantes, diques marginais podem ser encontrados em qualquer tipo de rio que sofra inundações, em qualquer regime climático (North \& Davidson, 2012), como rios entrelaçados (Bristow et al., 1999) e anastomosados (Tooth et al., 2008).

Depósitos de canais de rompimento de diques marginais (Fig. 4.6) podem ser dependentes da escala do rio (Miall, 1996), e podem chegar a vários metros de espessura, com algumas dezenas ou centenas de metros de largura e algumas centenas de metros de comprimento (Fielding, 1986). Em geral apresentam fácies arenosas, frequentemente com evidência de cessação periódica do fluxo, como gretas de contração em coberturas de lama, marcas de raízes, tubos e trilhas (Bridge, 2003). Os depósitos apresentam seções verticais com base côncava para o topo e topo plano, preenchidos por arenito com estraficação cruzada acanalada (Bridge, 1984; Bown \& Kraus, 1987), seguidos por arenito com laminação cruzada cavalgante, e muitas vezes estratificação cruzada de baixo ângulo (Miall, 1996, 2014). O preenchimento sedimentar pode apresentar geometrias mais complexas (Fielding, 1986), sugerindo atividade por mais de uma enchente. Escavações internas são comuns, assim como 


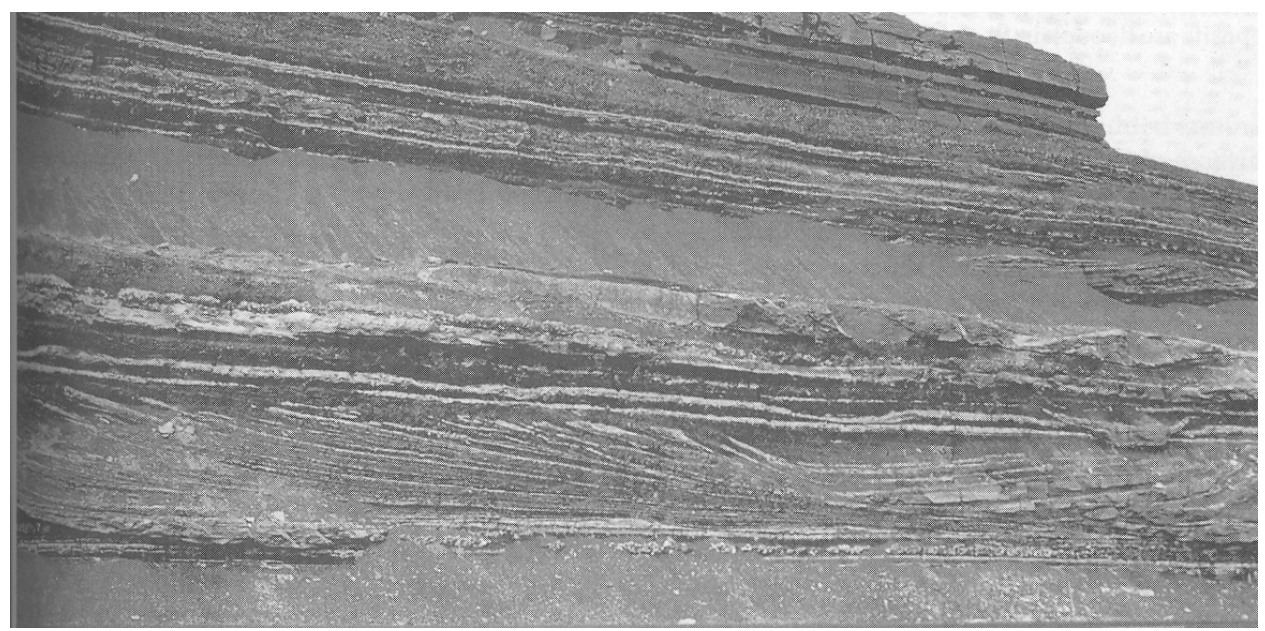

Fig. 4.7: Depósitos de finos na planície de inundação (pelitos, recuados no afloramento) intercalados a depósitos distais de rompimento de diques marginais (destacados). Notar a feições canalizada na base, que podem ser uma seção distal de um canal de crevasse (Miall, 1996).

a presença de depósitos residuais (lags) de granulação grossa, por vezes fossilíferos (Bown \& Kraus, 1987).

Lobos de rompimento de diques marginais (crevasse splays, Fig. 4.7) são descritos por Miall (1996) como semelhantes a depósitos de deltas, especialmente quado adentram pequenos corpos lacustres ou áreas inundadas. Porém, a analogia a leques aluviais proposta por North \& Davidson (2012) é provavelmente mais adequada para a maioria dos casos apresentados na literatura. Os depósitos têm forma de lobo, semelhantes a leques aluviais, a princípio simétricos e perpendiculares ao canal, mas que se elongam na direção do vale à medida que se desenvolvem (Smith \& Perez-Arlucea, 1994; Bridge, 2003; North \& Davidson, 2012), e podem alcançar comprimento de até $10 \mathrm{Km}$ e largura de $5 \mathrm{Km}$, com espessuras de 2 a $6 \mathrm{~m}$ (Miall, 1996). Apresentam geometria lenticular e têm topos cortados por pequenos canais, que podem ser a continuação do canal de rompimento de dique marginal (Miall, 1996; Bristow et al., 1999), mas com geometria em forma de cunha quando perpendicular ao canal principal (Bridge, 2003; Smith \& Perez-Arlucea, 1994). Os depósitos podem passar lateralmente de maneira gradual para depósitos de diques marginais. São compostos de areia fina a média (Miall, 1996), geralmente mais grossos que os depósitos de diques marginais (Bridge, 2003) com estratificação cruzada acanalada e laminação cruzada de pequeno porte, mas intercalações de pelitos são também comuns. Apresentam estratificação de pequena espessura, com bases erosivas de pequena escala, descontínuas, embora Gersib \& McCabe (1981) tenham descrito depósitos sem base erosiva. A granulação diminui em direção às bordas dos depósitos (Bristow et al., 1999), e podem apresentar também gradação normal em algumas camadas (Miall, 1996), com as partes mais distais de depósitos de rompimento de 


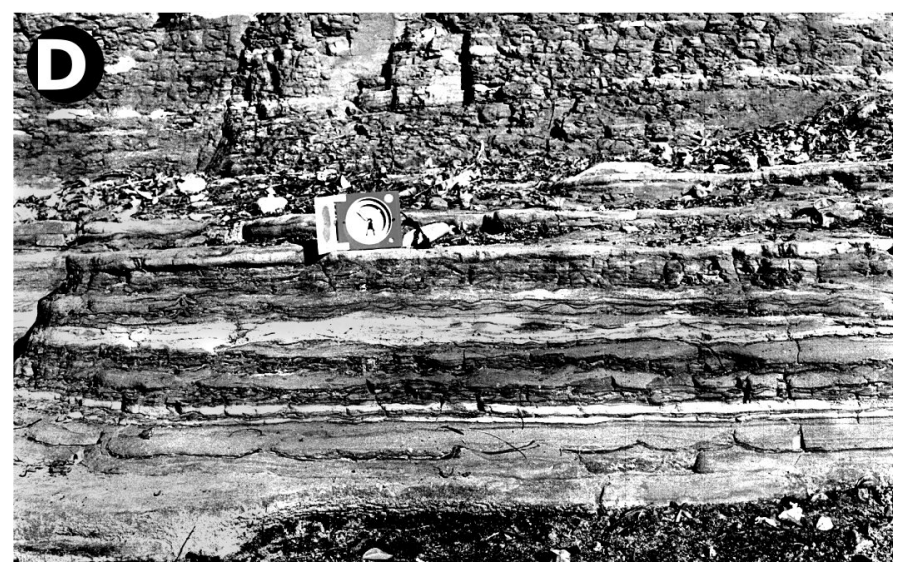

Fig. 4.8: Depósitos heterolíticos de finos de planície de inundação, intercalando níveis maciços de siltitos e níveis de arenitos com laminação cruzada (Almeida, 2005).

dique marginal assemelhando-se aos próprios depósitos de diques marginais (Bridge, 2003). Como os principais processos sedimentares se dão em um contexto de fluxo desconfinado, North \& Davidson (2012) descrevem esses depósitos como semelhantes a depósitos de leques aluviais, porém com faixa granulométrica limitada devido à capacidade de transporte típica de sistemas fluviais e sua origem na carga de suspensão presente nos canais durante as enchentes.

Os depósitos de finos de planície de inundação, ou de bacia de inundação (floodbasin, e.g., (Smith et al., 1989; Adams et al., 2004), consistem em depósitos com grande continuidade lateral e variedade litológica considerável. Estes depósitos podem apresentar evidências de deposição contínua, porém são comuns indicações de exposição durante períodos de seca, como gretas de contração em lama, ou mesmo sinais de pedogênese (Retallack, 1986; Bown \& Kraus, 1987; Miall, 1996). Os depósitos de bacias de inundação têm em geral granulação fina, com delgadas camadas de pelito ou de areia fina siltosa (Fig.

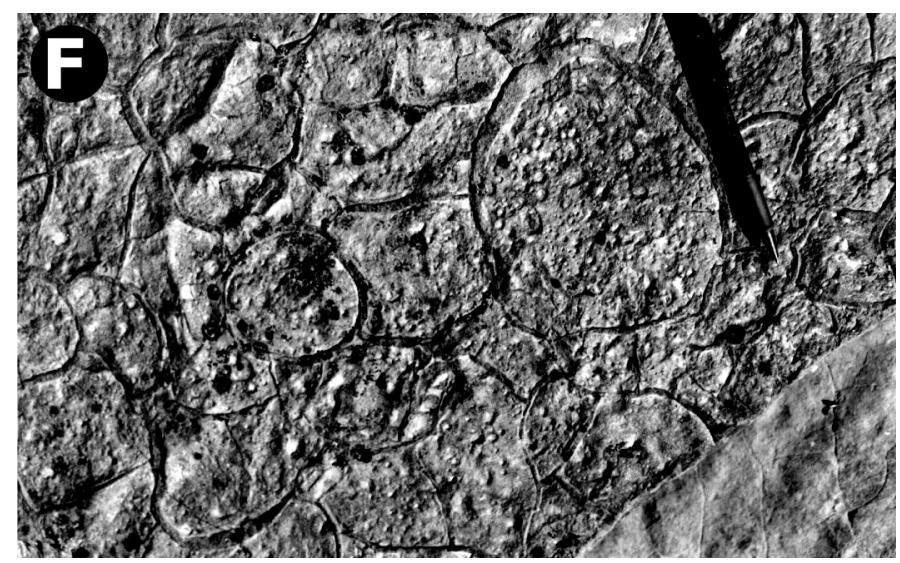

Fig. 4.9: Feições indicativas exposição subaérea e dissecação, com gretas de contração e marcas de pingos de chuva desenvolvidos sobre marcas onduladas (Almeida, 2005). 
4.8), finamente laminados (Bown \& Kraus, 1987; Fielding, 1986). Podem apresentar lâminas delgadas de arenitos e lentes com laminação cruzada. Embora transporte e deposição por suspensão de sedimentos em faixas granulométricas mais finas sejam comuns, partículas mais grossas também podem ser carregadas em suspensão com aumento da turbulência ou da carga sedimentar (Alexander et al., 1999; Fielding et al., 2011), o que pode explicar parte do aporte de areia para regiões mais distais da planície aluvial. Indicações de exposição subaérea são muito variadas, e vão desde gretas de contração em lama, até marcas de pingos de chuva (Fig. 4.9), assim como desenvolvimento de paleossolos, marcas de raízes e bioturbação (Allen \& Williams, 1982; Bown \& Kraus, 1987). Ocasionalmente, bacias de inundação de caráter efêmero, com indicações de exposição subaérea, podem dar lugar à formação de pequenos lagos perenes, especialmente se forem mal drenadas ou se o clima oferecer um regime pluvial favorável (Allen \& Williams, 1982). Nesse caso se espera encontrar características dos depósitos mais comuns a lagos, com delgadas lâminas planares contínuas com espessuras milimétricas a centimétricas. Podem apresentar também marcas onduladas por ação de onda (embora marcas onduladas na planície de inundação não sejam um aspecto exclusivo de pequenos corpos lacustres), somadas à ausência de estruturas como as gretas de contração (Bridge, 2003).

Preenchimentos de canais abandonados são formados a partir de avulsão tanto do canal principal quanto do abandono de canais em diques marginais ou de pequenos canais que drenam a planície de inundação (Bridge, 2003). Boa parte da história de preenchimento destes depósitos é semelhante à de depósitos lacustres (Miall, 1996). A estagnação de corpos de água se dá depois que as extremidades do canal abandonado são entulhadas com areia, até o ponto em que são isoladas do fluxo de água que alimentava o canal (Bridge, 2003). Os depósitos geralmente são compostos de areia com laminação cruzada (Gersib \& McCabe, 1981), que passam a depósitos de decantação de lama. Estruturas semelhantes a pequenos deltas lacustres podem formar-se na desembocadura destes canais (Bridge, 2003).

Depósitos de fluxo desconfinado podem ocorrer por toda a bacia, atingindo espessuras de até um metro em um evento episódico de inundação, em casos extremos. Bridge (2003) descreve pouca variação lateral de espessura, granulação ou estruturas sedimentares, embora em ampla revisão, North \& Davidson (2012) os considerem como mais complexos e variados do que geralmente concebido na literatura. São formados por arenitos finos a médios com estratificação cruzada, estratificação cruzada de baixo ângulo e estraficação plana, formados por deposição em regime de fluxo superior ou na transição entre regimes de fluxo inferior e superior (Bridge, 2003; Fielding et al., 2011). 
A simplicidade e pouca profundidade dos modelos de fácies resumidos acima refletem o reduzido número de publicações sobre as características dos depósitos de planícies de inundação fluviais e sobre os processos sedimentares atuantes em planícies modernas. Parte dessa simplificação, como apontado por North \& Davidson (2012), decorre da falta de integração na descrição de diferentes áreas da planície aluvial e da grande ênfase no estudo de processos e produtos internos ao cinturão de canais, resultando em visão limitada da complexidade e do papel de processos além-canal no registro de sistemas aluviais. Esse fato decorre principalmente da pouca relevância econômica desses depósitos em relação aos de canais fluviais, que constituem reservatórios de hidrocarbonetos em diversas bacias sedimentares. No contexto da reconstituição das características de sistemas fluviais pré-vegetação, entretanto, as planícies de inundação podem ter importância ainda maior que os sistemas de canais, pois apresentam características únicas, e podem ser elemento chave na compreensão da particularidade dos rios anteriores ao Siluriano.

\subsubsection{Planícies de inundação pré-vegetação}

Os modelos de depósitos sedimentares aluviais do Precambriano e do início do Paleozoico (Schumm, 1968; Cotter, 1978; Long, 1978, 2006; Eriksson et al., 2006) descritos dão pouca atenção aos depósitos de planícies de inundação, de maneira que sua descrição e interpretações são demasiadamente simplificadas, quando não ignoradas. Em casos específicos chega-se a assumir que toda a planície aluvial constitui um cinturão de canais durante picos de vazão (Cotter, 1978). Essa interpretação é de fato muito distinta da observação de inundação de todo o vale aluvial durante o pico de vazão, considerando-se que processos distintos ocorrem no cinturão de canais e na planície de inundação (e.g., Bridge, 2003; Bridge \& Demicco, 2008).

Parte dessas simplificações decorre dos modelos de sistemas fluviais construídos para sucessões mais recentes, nos quais de maneira geral se assume que planícies de inundação com sedimentação pelítica seriam características de sistemas fluviais meandrantes, enquanto que sistemas fluviais entrelaçados teriam planícies pouco desenvolvidas. A semelhança alegada entre sistemas fluviais Precambrianos e do início do Paleozoico e sistemas fluviais encontrados em ambientes áridos recentes (Schumm, 1968; Long, 2006), majoritariamente entrelaçados (Tooth, 2000), também contribuiu para a pouca relevância dada ao estudo de planícies de inundação anteriores à vegetação continental.

Entretanto, avanços recentes nos modelos de sistemas fluviais desafiam os modelos consagrados de rios entrelaçados, revelando planícies de inundação expressivas (Bentham et 
al., 1993; Sønderholm \& Tirsgaard, 1998; Bridge, 2003), além da descrição de planície de inundação de granulação grossa relacionadas a canais simples recentes (Alexander \& Fielding, 2006), sugerindo que a simplificação mencionada anteriormente pode ter condicionado erros de interpretação do registro sedimentar. Assim, pode-se supor que depósitos de planícies de inundação em sistemas fluviais pré-vegetação devem ser mais abundantes do que se acreditava. Além do aspecto que envolve a identificação de planícies de inundação de granulação mais grossa (como os descritos por Alexander \& Fielding, 2006), outro fator que dificulta a identificação de depósitos de planície de inundação pré-vegetação é a tendência de se interpretar depósitos pelíticos intercalados a arenitos como registro de sistemas costeiros (Davies \& Gibling, 2011), sob a argumentação de que a ausência de vegetação bem desenvolvida limitaria a produção de argilominerais na planície aluvial e nas encostas, e que todo o volume de lama sofreria bypass para ambientes marinhos.

Dentre os poucos trabalhos dedicados a estudos em maior detalhe da sedimentologia dos depósitos de planícies de inundação pré-vegetação, destacam-se as contribuições de Sønderholm \& Tirsgaard (1998), que descreveram depósitos aluviais neoproterozoicos na Groelândia, Hadlari et al. (2006), que descrevem depósitos continentais em um rift paleoproterozoico no norte do Canadá, e (Fralick \& Zaniewski, 2012), que estudaram depósitos de planícies de inundação mesoproterozoicos no sul do Canadá.

Sønderholm \& Tirsgaard (1998) descrevem três associações de fácies fluviais que se alternariam ao longo da história de preenchimento da área de estudo: associação de rios entrelaçados rasos, associação de planície entrelaçada lamosa e associação de enchentes em lençol efêmeras. Os depósitos identificados como planície de inundação ocorrem dentro da associação de planície entrelaçada lamosa, separada em depósitos de um sistema de canal entrelaçado e depósitos de planície de inundação, com finos de planície de inundação e depósitos de rompimento de diques marginais. Os autores não atribuem nenhum ambiente de planície de inundação aos outros sistemas fluviais.

Hadlari et al. (2006) descrevem toda a paleogeografia de um rift continental, com variedade de sistemas deposicionais, como sistemas fluviais axial e transversal, eólico, lacustre, playas e planícies de inundação, além de vulcanismo ácido associado. Na planície de inundação descrevem depósitos organizados em geometrias tabulares e cunhas de baixo ângulo, com arenitos com laminação cruzada, estratificação cruzada acanalada, marcas de onda, gretas de contração, e ocorrência de intraclastos de lama. A planície de inundação é lateral a um sistema fluvial entrelaçado, e seus depósitos são interpretados como depósitos de rompimento de diques marginais, finos de bacia de inundação depositados por decantação, e 
canais de rompimento de diques marginais sobre os depósitos pelíticos, além de depósitos de dunas eólicas desenvolvidos sobre a planície de inundação.

O trabalho mais completo sobre o tema é o de Fralick \& Zaniewski (2012), que se valeram de amostras de testemunhos para descrever em detalhe depósitos de planícies de inundação e definir um conjunto de características que os diferenciariam de depósitos pós-vegetação: melhor preservação de estruturas sedimentares de pequena escala; domínio de laminação ondulada em depósitos arenosos; geração em larga escala de clastos intraformacionais; preenchimento de gretas de contração por intraclastos ou por agregados de lama (partículas geradas na própria planície de inundação); deformação de sedimentos inconsolidados que sofreram exposição subaérea; e depósitos finamente laminados, sem deformação ou evidência de ressecamento. Além destas características, um aspecto que chama a atenção no trabalho é a ocorrência de uma facies heterolítica bastante deformada, descrita como a fácies mais comum dos depósitos estudados, e que teria sido formada por deformação de sedimento inconsolidado, combinando gretamento dos depósitos pelíticos, deposição de intraclastos de lama, e injeção de diques de arenito, indicando lençol freático próximo à superfície.

Algumas destas características enumeradas por Fralick \& Zaniewski (2012) são compartilhadas pelos exemplos anteriormente publicados, como a melhor preservação de estruturas sedimentares de pequena escala, a ocorrência generalizada de laminação cruzada em depósitos de arenitos finos e a ocorrência subordinada de fácies de arenitos com estratificação cruzada e laminação plano-paralela e depósitos de pelitos finamente laminados e não deformados (Sønderholm \& Tirsgaard, 1998; Hadlari et al., 2006), sendo que todas essas características seriam resultado direto da ausência de bioturbação por raízes (Fralick \& Zaniewski, 2012), e não diferem muito do conjunto de características esperados para sistemas fluviais pré-vegetação apontados em trabalhos anteriores (Schumm, 1968; Long, 1978, 2006; Cotter, 1978). A interpretação destas fácies não representa grande problema, pois são prontamente comparadas a exemplos de depósitos mais recentes, como depósitos de lobos e canais de rompimento de diques marginais.

A principal fonte de discrepância entre os exemplos citados reside na descrição de depósitos pelíticos e heterolíticos e suas estruturas particulares. Isso pode ser em parte resultado das descrições mais simplificadas de Sønderholm \& Tirsgaard (1998) e Hadlari et al. (2006), mas a grande variação de idade entre os exemplos citados, além dos diferentes contextos geológicos e paleoclimáticos também podem ser um fator decisivo para tais diferenças. 
A ocorrência comum de pequenos clastos intraformacionais descrita por Fralick \& Zaniewski (2012), seja na forma de agregados de lama ou de intraclastos pelíticos, não é descrita por Hadlari et al. (2006), e de pouca relevância no exemplo de Sønderholm \& Tirsgaard (1998), que só descrevem poucas gretas no sistema de rios efêmeros, sendo que os dois trabalhos mais antigos sequer mencionam a existência de agregados de lama, ou qualquer outra feição pedogênica. Outro aspecto conflitante é o grande volume de depósitos heterolíticos convolutos descritos por Fralick \& Zaniewski (2012), e sua inexistência nos outros exemplos, além da ocorrência de dunas eólicas na planície de inundação descrita por Hadlari et al. (2006), não observadas por Sønderholm \& Tirsgaard (1998) e Fralick \& Zaniewski (2012). Apesar destas diferenças, que poderiam ser decisivas para interpretações diversas do paleoclima durante a deposição, todos os autores interpretam seus sistemas deposicionais como desenvolvidos em cimas úmidos, com lençol freático próximo à superfície. Sønderholm \& Tirsgaard (1998) apontam como evidência de clima úmido a escassez de gretas de contração associada à presença de pequenos lagos perenizados, interpretados como indicação de lençol freático alto. Hadlari et al. (2006) usam de argumento similar, e apontam que as dunas eólicas teriam sido preservadas devido ao lençol freático alto, e que portanto não seriam indicativas de aridez em sistemas fluviais pré-vegetação. Fralick \& Zaniewski (2012), também interpretam um lençol freático alto, devido às injeções de areia por sobrecarga, que somadas à existência de pequenos lagos, ao pequeno tamanho das gretas e a formação limitada de agregados de lama, implicariam em clima úmido, já que gretas de maior dimensão precisariam de climas mais áridos, ou ao menos semiáridos, assim como a formação generalizada de agregados de solo (Marriott \& Wright, 2004; Muller et al., 2004).

Assim, os poucos trabalhos que abordam planícies de inundação fluviais pré-vegetação descrevem depósitos bastante distintos, porém chegam a conclusões semelhantes sobre o registro paleoclimático do ambiente interpretado. Em climas mais úmidos seria esperada maior pedogênese, mesmo com ausência de vegetação (Retallack, 2001), e pelo menos no exemplo de Fralick \& Zaniewski (2012) a pedogênese pode ter sido mais importante do que reconhecida pelos autores, uma vez que a deformação por sobrecarga pode não ter sido o único mecanismo gerador dos depósitos heterolíticos convolutos. A ausência de outros tipos de dados, como análises mineralógicas e químicas, além do próprio reconhecimento de paleossolos pré-cambrianos (Retallack, 1992), tornam estas interpretações paleoambientais bastante limitadas.

Apesar das discrepâncias destacadas entre estas diferentes contribuições ao estudo de planícies de inundação, é importante reconhecer que estes trabalhos trazem um conjunto de 
caracteres não só particulares a planícies de inundação pré-vegetação, mas que são relativamente comuns entre elas, principalmente a melhor preservação de estruturas sedimentares de pequena escala, como laminações cruzadas, ocorrência subordinada ou localizada de fácies com estratificação cruzada e laminação plano-paralela e ocorrência de depósitos heterolíticos, convolutos ou não. Porém a consideração de outros aspectos particulares, como presença de dunas eólicas, variadas frequências e dimensões de gretas de contração, formação de agregados de lama e formação de paleossolos ou de feições de paleopedogênese, devem ser levados em consideração reconhecimento de uma planície de inundação pré-vegetação. É importante notar que dentre os trabalhos de Sønderholm \& Tirsgaard (1998), Hadlari et al. (2006) e Fralick \& Zaniewski (2012), o modelo de planície de inundação mais simplificado está no trabalho mais antigo, e o modelo mais complexo e detalhado está no trabalho mais novo, indicando uma tendência de aumento do interesse no estudo destes depósitos, impulsionado provavelmente pelo aumento de interesse no estudo de suas contrapartes no cinturão de canais em sistemas fluviais pré-vegetação (Long, 2006, 2011; Davies \& Gibling, 2010; Davies et al., 2011).

\subsubsection{Paleossolos no Proterozoico e início do Paleozoico}

O interesse no estudo de paleossolos pré-cambrianos e do início do Paleozoico deve-se a suas aplicações na estratigrafia de sequências e à possibilidade de inferências sobre o paleoclima (e.g., (Driese \& Foreman, 1992; Driese et al., 1992; Retallack \& Mindszenty, 1994; Álvaro et al., 2003). Um importante impacto dos estudos de paleossolos pré-cambrianos é a percepção de que a ausência de vegetação não implica necessariamente em um intemperismo fraco ou incipiente, uma vez que proliferam descrições de paleossolos pré-cambrianos e do início do Paleozoico (Retallack \& Krinsley, 1993; Retallack \& Mindszenty, 1994; Love \& Williams, 2000; Nedachi et al., 2005; Driese et al., 2007; Retallack, 2008, 2009, 2011, 2012), sugerindo que poderia haver significativo intemperismo químico e produção de argilominerais mesmo em depósitos anteriores ao desenvolvimento de vegetação continental densa. Por outro lado, se o intemperismo nesta época pode equiparar-se ao atual (Driese et al., 2007), o mesmo não pode ser dito da variedade de tipos de paleossolos encontrados (Retallack, 2001; Bridge, 2003), devido a ausência de cobertura vegetal, que preclui a formação de tipos específicos de paleossolos. Mesmo assim, embora a variedade de paleossolos pré-silurianos não seja tão grande, é possível identificar pedofácies ou pedotipos (Bown \& Kraus, 1987) diferentes em um determinado ambiente, que podem representar variação de maturidade, por exemplo (e.g., Retallack 2012). 
Paleossolos pré-silurianos apresentam dificuldades de identificação óbvias, como ausência de marcas de raízes (Bown \& Kraus, 1987), além de outros aspectos comuns a sucessões sedimentares antigas, como deformação posterior, possibilidade de metamorfismo, afloramentos desfavoráveis (especialmente os muito alterados), e a facilidade com que se pode confundir paleossolos com depósitos fluviais granodecrescentes, depósitos de fluxos de massa lamosos, depósitos de cinzas e produtos de alteração por fluidos hidrotermais, entre outros (Retallack, 1992; Retallack \& Krinsley, 1993; Mitchell \& Sheldon, 2009).

Parte dos estudos de paleossolos é desenvolvida em planícies de inundação, onde o desenvolvimento do solo se dá sobre depósitos recém-sedimentados (e.g., Retallack \& Krinsley, 1993; Álvaro et al., 2003; Mitchell \& Sheldon, 2009; Retallack, 2012), enquanto que outros estudos descrevem paleossolos desenvolvidos sobre protolitos como gnaisses e rochas vulcânicas, geralmente cobertos posteriormente por depósitos sedimentares (e.g., Beukes et al., 2002; Nedachi et al., 2005). Independente da abordagem ou da área estudada, podem ser encontrados paleossolos que desenvolvem um zoneamento vertical bem definido, com preservação de topos de perfis de solo bastante lixiviados e com bases relativamente pouco intemperizadas, preservação de estrutura ou composição do protolito (e.g., Álvaro et al., 2003; Driese et al., 2007), enquanto em outros exemplos podem ser encontrados solos com desenvolvimento incipiente (e.g., Entissolos de Mitchell \& Sheldon, 2009). Características particulares do zoneamento de níveis de paleossolo podem conduzir a inferências particulares sobre o clima, como o relativo enriquecimento de ferro no topo de perfis dos paleossolos Heckpoort (Beukes et al., 2002) e o Waterval Onder (Retallack, 1992), que indica atmosfera oxidante no Paleoproterozoico, ou a formação de horizontes de concreções calcíticas em profundidade, que (Retallack, 2009) relacionou a regimes de aumento de temperatura e pluviosidade.

Além de servirem como marcadores estratigráficos (e.g., Álvaro et al., 2003; Retallack, 2009) e como proxies paleoclimáticos (e.g., Beukes et al., 2002; Retallack, 2011), paleossolos tem um potencial relativamente pouco explorado como evidência de atividade biológica na superfície terrestre. Beukes et al. (2010) chegaram a atribuir a mobilidade de ferro em um perfil laterítico à atividade biológica, de maneira comparável a lateritas tropicais modernas, porém relacionada a possíveis esteiras microbianas que residiriam apenas no topo do perfil de solo, posteriormente erodido.

Descrições de planícies de inundação com feições que poderiam se interpretadas como fruto de paleopedogênese (e.g., Fralick \& Zaniewski, 2012), ou com descrição de paleossolos (e.g., Love \& Williams, 2003), assim como o registro de retrabalhamento destes paleossolos 


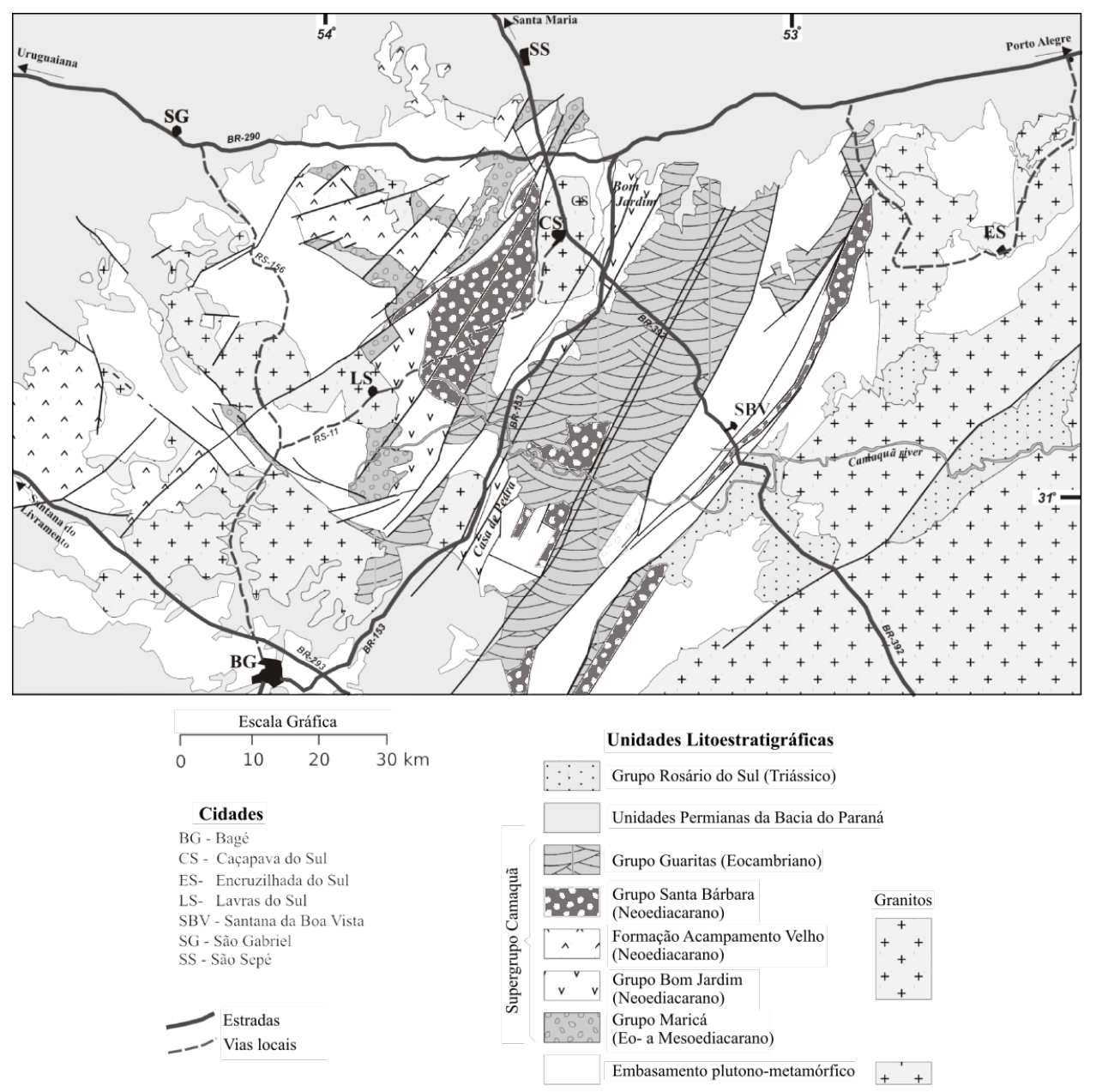

Fig. 4.10: Mapa regional da Bacia Camaquã, com suas principais unidades estratigráficas (modificado de Almeida 2005).

na planície aluvial, seja pela sedimentação de agregados de lama (Marriott \& Wright, 2004; Muller et al., 2004; Wright \& Marriott, 2007), ou por retrabalhamento de solo da encosta próxima do vale aluvial (e.g., Mitchell \& Sheldon, 2009), tornam planícies de inundação ambientes ideais para o estudo de paleossolos, e por extensão para o estudo das condições paleoclimáticas e mesmo da existência e influência de atividade biológica na superfície terrestre.

\subsection{Areas de estudo}

\subsubsection{Supergrupo Camaquã}

O Supergrupo Camaquã é parte de um conjunto de sucessões de depósitos siliciclásticos e vulcanogênicos de idade neoproterozoica a ordoviciana que ocorrem em pequenas bacias limitadas por falhas da província Mantiqueira no Uruguai nas regiões sul e 
sudeste do Brasil (e.g., Almeida, 1967, 1969; Almeida et al., 2010). Essas bacias contêm abundantes conglomerados e arenitos de ambientes continentais, associados a rochas vulcânicas e granitoides de afinidade alcalina.

Dentre essas bacias, a Bacia do Camaquã é a mais espessa e bem exposta, tendo sido tradicionalmente considerada junto com algumas das demais bacias como relacionada a sedimentação sin-orogênica da Orogenia Brasiliana (e.g., Fragoso-Cesar et al., 1984, 1985; Fragoso-Cesar, 1991). Trabalhos posteriores favorecem interpretações de bacias policíclicas, formadas em contextos distensivos ou transtrativos, ao menos em seus estágios finais(e.g., Oliveira \& Fernandes, 1991, 1992; Machado \& Sayeg, 1992; Gresse et al., 1996; Fragoso-Cesar et al., 2000; Paim et al., 2002; Fambrini, 2003; Janikian et al., 2003, 2008; Teixeira et al., 2004; Almeida, 2005; Almeida et al., 2009, 2010, 2012).

O Supergrupo Camaquã (Fig. 4.10), no conceito de (Fragoso-Cesar et al., 2000) e adaptações posteriores, é composto por cinco unidades maiores: Grupo Maricá (siliciclástica inferior), Grupo Bom Jardim (vulcânicas básicas e ácidas, depósitos siliciclásticos e vulcanoclásticos), Formação Acampamento Velho (vulcânicas e vulcanoclásticas ácidas), Grupo Santa Bárbara (siliciclástica) e Grupo Guaritas (siliciclástica sobre discordância angular).

O preenchimento sedimentar da bacia cobre um período que vai de cerca de $590 \mathrm{Ma}$ à $535 \mathrm{Ma}$, cobrindo desde o fim do Neoproterozoico até o início do Cambriano (Chemale Jr., 2002; Hartmann et al., 2008; Janikian et al., 2008; Almeida et al., 2010; Janikian et al., 2012; Oliveira et al., 2014).

Devido ao foco da presente tese, adiante serão apresentados em detalhe a evolução dos conhecimentos sobre os Grupos Santa Bárbara e Guaritas.

\section{Grupo Santa Bárbara}

O Grupo Santa Bárbara (Almeida, 2005; Fambrini et al., 2006) é composta por mais de $2.000 \mathrm{~m}$ de conglomerados polimíticos, arcósios grossos a finos com estratificação cruzada, ritmitos silto-arenosos e siltitos argilosos, depositados do fim do Neoproterozoico ao início do Cambriano. Em sua área tipo, na sub-bacia Camaquã Ocidental (Fig. 4.10), a base da unidade estratigráfica está posicionada logo acima do registro de vulcanismo ácido da Formação Acampamento Velho, e tem seu topo separado de depósitos do Grupo Guaritas por discordância angular.

Trabalhos anteriores incluem mapeamento regional e propostas de divisão litoestratigráfica (e.g., Carvalho, 1929, 1932; Leinz, 1939; Leinz et al., 1941; Goñi et al., 
1962; Ribeiro et al., 1966; Robertson, 1966; Tessari \& Picada, 1966; Ribeiro \& Fantinel, 1978; Ribeiro \& Lichtenberg, 1978) além de interpretações de sistemas deposicionais e evolução estratigráfica (e.g., (Fragoso-Cesar et al., 1985; Lavina et al., 1985; Faccini et al., 1987; Fambrini, 1998, 2003; Almeida, 2001, 2005; Fambrini et al., 2006, 2007).

As sucessões sedimentares do Grupo Santa Bárbara foram objeto de estudo de estratigrafia de sequências conduzidos por Paim et al. (1992, 1995) e Paim (1994), que a subdividiu com base no contexto de alogrupos e aloformações. As unidades foram elevadas para a categoria de grupo por Fambrini (1998), em estudo detalhado de fácies e proveniência nos depósitos na região das Minas do Camaquã, que interpreta sua origem como resultante de sedimentação em bacia tectonicamente ativa, interpretada como distensiva por Fragoso-Cesar et al. (2000), em contexto de bacias do tipo rift.

A proposta estratigráfica de Paim et al. (2002) separa os depósitos do Grupo Santa Bárbara em dois alogrupos distintos, incluindo os conglomerados inferiores da unidade no topo do Alogrupo Cerro do Bugio (Aloformação Santa Fé) e as demais unidades (aloformações Serra dos Lanceiros e Pedra do Segredo) no Alogrupo Santa Bárbara. Com a finalidade de resolver dificuldades de correlação entre diferentes ocorrências da unidade, Fambrini (2003) estende o conceito de Grupo Santa Bárbara da região das Minas do Camaquã, na sub-bacia central, para as sucessões do Vale do Santa Bárbara, a oeste, e do Vale do Piquiri e Rincão dos Mouras, a leste, enquanto que (Fambrini et al., 2005) estendem a mesma estratigrafia para depósitos do Grupo Santa Bárbara encontrados na região de Bom Jardim, em contato tectônico com o Grupo Bom Jardim (Janikian, 2004).

Almeida (2005) em estudo concentrado na região do Vale do Santa Bárbara interpreta a bacia como preenchida por sistemas deposicionais continentais, predominantemente sistemas aluviais, sem no entanto correlacionar os depósitos da região do Vale do Santa Bárbara com outras ocorrências, e subdivide a unidade em sua área tipo em cinco formações: Formação Estância Santa Fé, com depósitos de leques aluviais e de rios entrelaçados; Formação Seival, com depósitos distais de rios efêmeros; Formação Serra dos Lanceiros, com depósitos de rios entrelaçados; Formação Arroio Umbu, com depósitos de leques aluviais e de rios efêmeros; Formação Pedra do Segredo, com depósitos de leques aluviais e de rios entrelaçados.

Almeida (2001) em mapeamento litofaciológico Grupo Santa Bárbara na Sub-Bacia Camaquã Ocidental propôs, com base em análises de paleocorrentes e de proveniência macroscópica, que o soerguimento do Alto de Caçapava do Sul e a consequente erosão do granito homônimo foi simultânea a unidades superiores do Grupo Santa Bárbara, hipótese 
corroborada por trabalhos posteriores com base em dados isotópicos e de dados adicionais de proveniência macro- e microscópica (Borba \& Mizusaki, 2002, 2003; Justo, 2003; Justo \& Almeida, 2004; Almeida, 2005; Marconato, 2010).

\section{Grupo Guaritas}

O Grupo Guaritas compreende sucessões sedimentares siliciclásticas depositadas em uma bacia distensiva ao fim do ciclo de deposição do Supergrupo Camaquã (Paim, 1994; Almeida, 2005; Almeida et al., 2009). A colocação de corpos intrusivos da Suíte Intrusiva Rodeio Velho em sedimentos inconsolidados da seção intermediária do Grupo Guaritas (Almeida, 2005) permite posicionar a unidade no Cambriano, conforme idades obtidas por método Ar/Ar em rocha total de 535,2+/-1,1 Ma (Almeida et al., 2009), e U/Pb em zircão 547+/-6 Ma (C. H. E. Oliveira et al., 2014), além de datação U/Pb em zircões detríticos de Hartmann et al. (2008), que têm seu zircão mais jovem datado em 535+/-10 Ma.

A separação dos depósitos do Grupo Guaritas como unidade estratigráfica remonta a estudos de Robertson (1966) na região de serras homônima, a norte das Minas do Camaquã. Subdivisão de unidades estratigráficas se dá pelo reconhecimento dos membros Guarda Velha, conglomerático, e Varzinha, com arenitos e siltitos intercalados (Ribeiro, 1970; Ribeiro \& Lichtenberg, 1978). Arenitos com estratificação cruzada de grande porte encontrados no morro da Pedra Pintada foram atribuídos ao Grupo Santa Bárbara por (Ribeiro et al., 1966), sendo posteriormente interpretados como depósitos eólicos e reconhecidos em outras partes da bacia (e.g., Becker \& Fernandes, 1982; Fragoso-Cesar, 1984; Fragoso-Cesar et al., 1984; Lavina et al., 1985; Faccini et al., 1987), sendo que a denominação Pedra Pintada aplicada a arenitos de origem eólica foi introduzida por Fragoso-Cesar, (1991), sendo utilizada desde então em trabalhos sobre depósitos eólicos (e.g., Paim et al., 1995, 2002; Fragoso-Cesar et al., 1999; Paim \& Scherer, 2003; Almeida et al., 2009).

A determinação da espessura total da unidade depende do empilhamento estratigráfico, uma vez que dados de subsuperfície, como a sondagem utilizada por Lopes et al. (1999) para determinar espessura de 385 m para a unidade, são limitados. Paim (1994) estimou espessura em torno de $800 \mathrm{~m}$ para a sucessão, enquanto que Almeida et al. (2009) sugerem uma espessura superior a $1500 \mathrm{~m}$ para a unidade, com base na integração de seções estratigráficas e diferentes partes da bacia

Interpretações de ambientes deposicionais para o Grupo Guaritas foram propostas desde os primeiros estudos estratigráficos, com o reconhecimento de leques aluviais por Robertson (1966), depósitos fluviais e de deltas lacustres por Ribeiro et al. (1966), além dos 
leques aluviais, e fácies marinhas costeiras por Faccini et al. (1987). Os depósitos de canais fluviais de rios entrelaçados, de planície eólica e de deltas lacustres foram posteriormente detalhados por Fragoso-Cesar (1984), Fragoso-Cesar et al. (1984, 1985) e Lavina et al. (1985). Paim (1994) reavaliou os depósitos interpretados como ambiente costeiro de Faccini et al. (1987), interpretando as mesmas fácies como de interdunas úmidas, e refinou os modelos de deposição aluvial e eólica, incluindo também reclassificação das sucessões sedimentares com base na aloestratigrafia (Paim et al., 1992, 1995; Paim, 1994). Com base nos depósitos aluviais, Paim (1995) propôs uma reconstituição da paleogeografia, enquanto que Paim (1996) em trabalho específico sobre depósitos eólicos, enfatizou a presença de interdunas úmidas. Em compasso com os estudos de ambientes deposicionais, De Ros et al. (1994), em estudo petrográfico detalhado determinaram um ambiente semiárido para a unidade, especialmente devido a presença de clastos de calcrete em amostras de arenito.

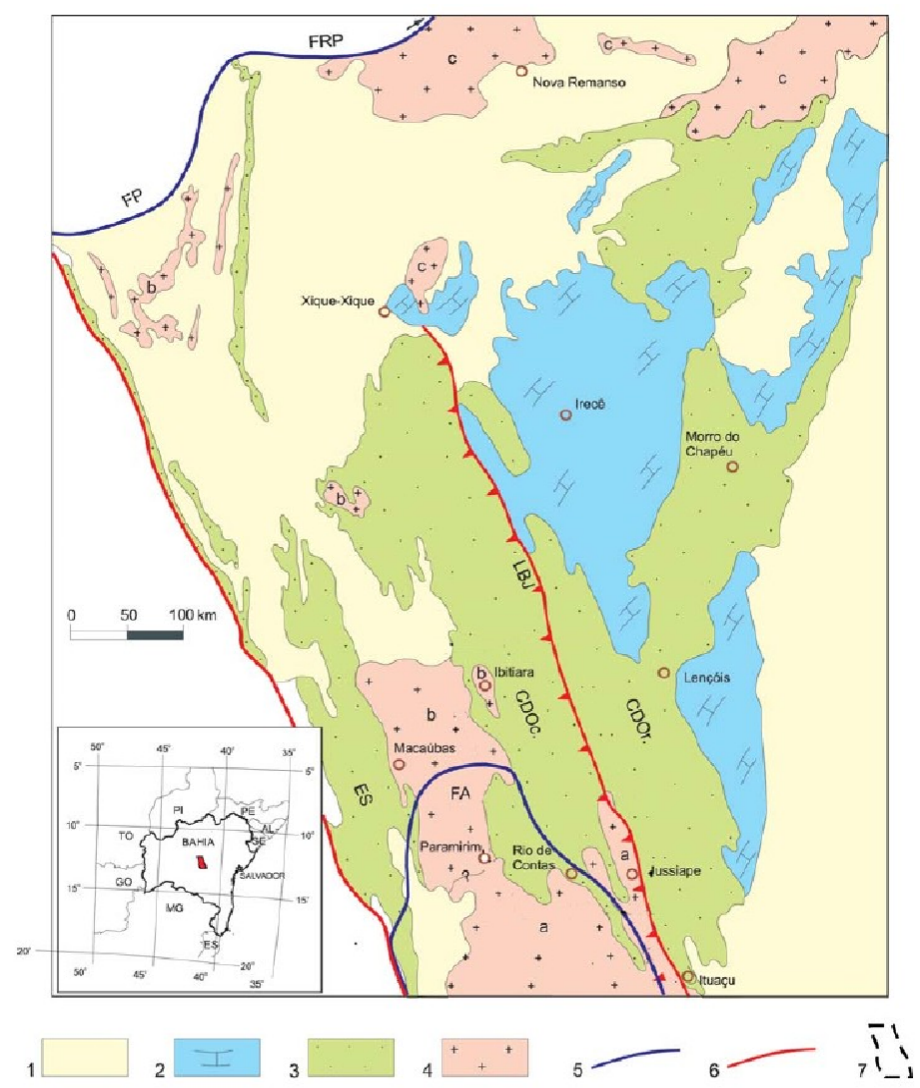

Fig. 4.11: Mapa geológico simplificado da região da Chapada Diamantina Espinhaço Setentrional . 1- Cobertura fanerozóica; 2 - Supergrupo São Francisco; 3 - Supergrupo Espinhaço (ES - Espinhaço Setentrional; CDOc Chapada Diamantina Ocidental; CDOr - Chapada Diamantina Oriental); 4 Embasamento Pré-Espinhaço (a - Bloco Gavião; b - Bloco Paramirim; c Bloco Sobradinho); 5 - Limites do Cráton do São Francisco (FA - Faixa Araçuaí; FP - Faixa Rio Preto; FRP - Faixa Riacho do Pontal); 6 - Limites do Corredor de Deformação do Paramirim (LBJ - Lineamento Barra do Mendes - João Correia). Extraída de Martins et al. (2008). 
Almeida (2005) propõe nova subdivisão estratigráfica para a unidade com base em reconhecimento de superfícies regionais, interpretadas como reflexo de importantes modificações paleogeográficas, aprimorada por Almeida et al. (2009). Desta forma, propôs a Formação Guarda Velha como unidade basal do Grupo Guaritas, composta por depósitos fluviais, seguidos pelas formações Varzinha, Pedra Pintada e Pedra das Torrinhas, que compõem ambientes fluviais, eólicos e de leques aluviais contemporâneos, seguidos por depósitos fluviais da Formação Serra do Apertado. Almeida et al. (2009) integra as interpretações sobre a estratigrafia da bacia a seu tectonismo, que permitiram associar eventos de reativação tectônica à alternância de captura de sistemas aluviais axiais e de preenchimento da bacia por sistemas transversais.

Estudos de proveniência isotópica realizado por Borba et al. (2003) e por Hartmann et al. (2008) (em zircões detríticos), reconheceram a assinatura de fontes relacionadas ao embasamento encontrado no Alto da Serra das Encantadas, corroboradas por estudos de proveniência em minerais pesados por Nóbrega et al. (2008) e em depósitos conglomeráticos (Almeida et al., 2009; Godinho, et al., 2013a).

Embora os depósitos eólicos tenham atraído grande atenção, em estudos que abordam a arquitetura deposicional (e.g., Paim et al., 2002; Paim \& Scherer, 2003; Scherer et al., 2003; Teixeira et al., 2004; Paim \& Scherer, 2007), há crescente interesse em estudos focados em particularidades de sucessões fluviais, incluindo estudos sobre depósitos da Formação Guarda Velha (Paim, 1994; Santos et al., 2012, 2014), Formação Serra do Apertado (Almeida, 2005; Godinho et al., 2013b), e sobre os depósitos de leques aluviais da Formação Pedra das Torrinhas e sua interação com depósitos eólicos da Formação Pedra Pintada (Marconato et al., 2009; Godinho, 2013a; Godinho, et al., 2013b)(Marconato et al., 2009; Godinho et al., 2013a; 2013b).

\subsubsection{Supergrupo Espinhaço na Chapada Diamantina}

A Serra do Espinhaço (sensu Derby, 1906), uma unidade fisiográfica com orientação $\mathrm{N}-\mathrm{S}$ e elevações que ultrapassam os $1000 \mathrm{~m}$ de altitude, é considerada um sítio clássico da geologia brasileira devido à ocorrência de depósitos diamantíferos. O substrato geológico destas serras é formado essencialmente pelo Supergrupo Espinhaço, composto por rochas sedimentares e metassedimentares pré-cambrianas, notadamente siliciclásticas psamíticas.

$\mathrm{Na}$ Bahia o Supergrupo Espinhaço é dividido em dois domínios: o Espinhaço Setentrional e a Chapada Diamantina, separados pelo embasamento que aflora na região do 
vale do Rio do Paramirim, sendo que a região da Chapada Diamantina pode ser dividida, baseado em contrastes estratigráficos e estruturais, nas províncias Ocidental e Oriental, separadas pelo Lineamento Barra do Mendes - João Correia, de direção NNW/SSE (Jardim de Sá et al., 1976) (Fig. 11).

Na região da Chapada Diamantina Ocidental afloram, da base para o topo, os grupos Rios dos Remédios, Paraguaçu e Chapada Diamantina, sendo que o último ocorre de forma restrita, em núcleos de sinclinais (Inda \& Barbosa, 1978; Dominguez, 1993; Martins et al., 2008). Além da presença de unidades basais do Supergrupo Espinhaço, outro aspecto desta região é a deformação mais intensa, com dobras fechadas, zonas de cisalhamento e empurrões.

O Grupo Rio dos Remédios (Martins et al., 2008) é uma sucessão vulcano-sedimentar, com rochas vulcânicas e sub-vulcânicas ácidas da Formação Novo Horizonte na base, consideradas como início de uma tafrogênese e datadas por meio de análise $\mathrm{U}-\mathrm{Pb}$ em zircões em cerca de 1,7 Ga (Babinski et al., 1994; Schobbenhaus et al., 1994). A sucessão sedimentar é formada por conglomerados, arenitos e pelitos, que compõem ambientes aluviais, na Formação Ouricuri do Ouro, e lacustres, na Formação Lagoa de Dentro, em contexto de rift continental (Martins et al., 2008).

O Grupo Paraguaçu, dividido nas formações Mangabeira e Araçuá (Schobbenhaus \& Kaul, 1971; Inda \& Barbosa, 1978), compõe uma sucessão sedimentar de ambiente costeiro e marinho raso, depositados em discordância erosiva sobre o Grupo Rio dos Remédios, representando uma deposição em área mais ampla, em fase de sedimentação pós-rift (Martins et al., 2008).

Na Região da Chapada Diamantina Oriental, a área de estudo, em contraste à porção ocidental, é dominada pelos depósito do Grupo Chapada Diamantina, formada da base para o topo pelas formações Tombador, Caboclo e Morro do Chapéu, com deformação mais branda, com dobras abertas e de grande amplitude, com estruturas sedimentares preservadas e metamorfismo de muito baixo grau (Schobbenhaus, 1996).

A Formação Tombador está em contato discordante sobre rochas ígneas e metamórficas do embasamento arqueano próximo a Morro do Chapéu e Jacobina, enquanto que na região entre Lençóis e Morro do Chapéu a unidade está sobreposta aos depósitos da Formação Paraguaçu, sugerindo área deposicional mais ampla. A Formação Tombador é composta por arenitos e conglomerados, interpretados como sistemas de leques aluviais, fluviais e eólicos depositados em ambiente continental (Pedreira, 1988; Otero et al., 1989; Bomfim et al., 1990; Pedreira, 1997), com paleocorrentes predominantemente para oeste 
indicando uma área fonte importante à leste da Chapada Diamantina, na região de Jacobina (Otero et al., 1989; Pedreira \& Margalho, 1990; Pedreira, 1997).

Os depósitos da Formação Tombador passam gradualmente para arenitos finos e pelitos intercalados e carbonatos da Formação Caboclo, interpretada como depósitos marinhos plataformais em transgressão sobre as sucessões continentais sotopostas (Dominguez, 1993). Datações U-Pb em calcários da Formação Caboclo indicaram uma idade mínima de 1140 +/$140 \mathrm{Ma}$, correspondente ao anquimetamorfismo das rochas (Babinski et al., 1993). A Formação Morro do Chapéu, com arenitos e conglomerados depositados em ambiente fluvial, se assenta em discordância sobre a Formação Caboclo, e representaria uma sequência deposicional distinta da formada pelas formações Tombador e Caboclo (Dominguez, 1993).

As sucessões basais do Supergrupo Espinhaço teria sido depositado em uma bacia do tipo rift, instalado em falhas de direção N/S a NW/SE (Jardim de Sá et al., 1976; Inda \& Barbosa, 1978; Brito-Neves et al., 1980; Jardim de Sá, 1981; Costa \& Inda, 1982). A abertura do rift seria associada ao vulcanismo ácido do Grupo Rio dos Remédios, com preenchimento da bacia por depósitos continentais da mesma unidade durante a subsidência mecânica e do Grupo Paraguaçu durante uma fase de relaxamento térmico, que é seguida após discordância, pela deposição do Grupo Chapada Diamantina, já num contexto de bacia do tipo sinéclise (Dominguez, 1993; Martins et al., 2008).

\section{Formação Tombador}

A Formação Tombador é a unidade com maior área de afloramento da Chapada Diamantina, compondo paredes das mesas características da região. Sua seção tipo se localiza na Serra do Tombador, embora sua área de ocorrência se estenda a sul, na região de Lençóis e da Serra do Sincorá (Martins et al., 2008). A despeito das boas exposições, são os poucos os trabalhos dedicados a estudos sedimentares de detalhe, sendo que os estudos existentes são dedicados principalmente a mapeamentos e construção de modelos tectônicos (Pedreira, 1988; Bomfim et al., 1990; Dominguez, 1993). (Otero et al., 1989) descrevem a sedimentação flúvio-eólica na Formação Tombador, onde identificam nas proximidades de Morro do Chapéu sistemas fluviais efêmeros com paleocorrentes para oeste, com indicações de retrabalhamento eólico dos depósitos fluviais, como níveis de deflação eólica e lençóis de areia, A norte desta área, próximo de Jacobina e Miguel Calmon, ocorrem depósitos de campos de dunas eólicas, com paleoventos para norte, sugerindo que aos depósitos fluviais efêmeros localizados a sul seriam sua área fonte mais provável. 


\title{
Pre-vegetation fluvial floodplains and channel-belts in the Late Neoproterozoic-Cambrian Santa Bárbara group (Southern Brazil)
}

\author{
André Marconato $^{\mathrm{a}, *}$, Renato Paes de Almeida ${ }^{\mathrm{b}}$, \\ Bruno Boito Turra ${ }^{a}$, Antônio Romalino dos Santos Fragoso-Cesar ${ }^{a}$ \\ a Institute of Geosciences, University of São Paulo (USP), Rua do Lago, 562, São Paulo, SP 05508-080, Brazil \\ ${ }^{\mathrm{b}}$ Institute of Energy and Environment, University of São Paulo (USP), Av. Professor Luciano Gualberto, 1289, São Paulo, SP 05508-080, Brazil
}

\section{A R T I C L E I N F O}

\section{Article history:}

Received 14 August 2013

Received in revised form 5 November 2013

Accepted 5 November 2013

Available online 15 November 2013

Editor: Jasper Knight

\section{Keywords:}

Pre-vegetation

Floodplains

Channel-belts

Ediacaran

Cambrian

Fluvial processes

\begin{abstract}
A B S T R A C T
One key element to the understanding of the dynamics of pre-vegetation fluvial systems is the reconstruction of processes operating on their floodplains given that, in modern systems, channel banks and floodplains are the environments most affected by plant colonization. Notwithstanding, few pre-vegetation floodplains have been described, and major questions regarding their most basic characteristics are still unresolved. In order to address these questions, detailed analysis of coeval channel-belt, fluvial floodplain and alluvial-fan deposits from the Santa Bárbara Group (Late Neoproterozoic to Early Cambrian, southern Brazil) was performed. While floodplain facies resemble ephemeral stream deposits, being coarser-grained than modern floodplains and marked by the stacking of flood event cycles, channel-belt deposits show composite bars, which do not present conclusive evidence for high water discharge variation. The floodplain deposits show particular features common to other pre-vegetation fluvial systems, such as better preserved small-scale structures, lack of bioturbation, and abundance of cross-laminated sandstones, while other features differ from previous depositional models, namely abundant mudcracks and evidence of soil formation. The lateral variation of depositional systems recorded in the Santa Bárbara Group shows contrasting signatures of water discharge variation in sand-dominated coeval environments, and offers an example of the relation between different alluvial environments before the evolution of land plants.
\end{abstract}

\section{Introduction}

One major aspect in the evolution of fluvial systems through time is the stabilization of river banks and the indirect control on river discharge promoted by vegetation, partly through the development of fine-grained floodplains (Schumm, 1968; Cotter, 1978; Long, 1978; Davies and Gibling, 2010; Davies et al., 2011). Most of the literature on the subject focuses on the pre-Silurian fluvial systems arising in the absence of land plants (e.g., Fuller, 1985; Rainbird, 1992; Bhattacharyya and Morad, 1993; Hjellbakk, 1997; Long, 2006), and in recent years there has been increasing interest in the effects of land plants on channel styles (Davies and Gibling, 2010; Davies et al., 2011). Both these approaches are based primarily on descriptions of channel facies. Notwithstanding, the absence of vegetation in preSilurian systems is expected to have influenced more than just the channel style, controlling depositional and post-depositional processes on the whole subaerial realm (e.g., Murray et al., 2008; Corenblit and Steiger, 2009).

In this context, the study of pre-vegetation floodplains is critical to the understanding of the dynamics of Precambrian to Early Paleozoic

\footnotetext{
* Corresponding author.

E-mail address: andre.marconato@usp.br (A. Marconato).
}

fluvial systems. Floodplains are the location of intense plant colonization in modern environments and therefore are highly sensitive to the controls imposed by vegetation on sedimentation. The description of pre-vegetation floodplains is scarce in the literature (e.g., Sønderholm and Tirsgaard, 1998; Hadlari et al., 2006; Fralick and Zaniewski, 2012), which may be due to difficulties in their recognition caused by the absence of modern analogs for non-vegetated, periodically flooded areas next to perennial channels. The current models for post-Silurian floodplains generally consider the dominance of mud deposits (e.g., Bentham et al., 1993; Bridge, 2000), however, the description of coarse-grained floodplains related to modern single channel rivers (Alexander and Fielding, 2006) suggests that the idea of floodplain deposits as finegrained environments may have led to misinterpretations in the sedimentary record, and to the overlooking of pre-vegetation floodplains. On the other hand, the limited number of described Proterozoic and early Paleozoic floodplains (e.g., Sønderholm and Tirsgaard, 1998; Hadlari et al., 2006; Fralick and Zaniewski, 2012) has been used to suggest low production of clay minerals prior to plant colonization of the land, coupled with bypass of mud to marine environments (e.g., Winston, 1978; Eriksson et al., 2006; Davies et al., 2011). However, the record of Proterozoic fine-grained floodplains, as described by Sønderholm and Tirsgaard (1998), is possibly much more frequent than what has been recorded in the literature. 
This work presents descriptions and interpretations of coeval channel-belts, fluvial floodplains and alluvial fans from the Santa Bárbara Group (southern Brazil), deposited in a Late Neoproterozoic to Early Cambrian fault-bounded basin. Particular facies and facies associations are recognized, bringing new light to the nature of prevegetation alluvial plains, with the proposal of a sedimentary model that describes the relation of pre-vegetation floodplains with nearby environments, which can improve the understanding of landscape evolution during the transition from the late Neoproterozoic and early Paleozoic.

\section{Geological setting and stratigraphy}

The Santa Bárbara Group (sensu Fambrini, 2003) is part of the Camaquã Supergroup (Fragoso-Cesar et al., 2000) and crops out in southernmost Brazil (Fig. 1), overlying Paleo- and Neoproterozoic rocks that were involved in the Neoproterozoic orogenic events of Eastern Gondwana as part of a system of fault-bounded basins that extends from Uruguay to Southeastern Brazil (Almeida et al., 2010, 2012). The Camaquã Supergroup comprises unmetamorphosed sedimentary and volcanogenic rocks deposited between ca. $590 \mathrm{Ma}$ and $535 \mathrm{Ma}$ (Chemale Jr., 2002; Janikian et al., 2008, 2012; Almeida et al., 2010). The Santa Bárbara Group is found in three sub-basins of the Camaquã Basin (Fig. 1), separated by basement highs. Because these occurrences cannot be easily correlated, the Santa Bárbara Group includes all siliciclastics younger than the volcanic rocks of the Acampamento Velho Formation and older than the angular unconformity at the base of the overlying (more than 1000 m thick) Guaritas Group (Almeida et al., 2009; Marconato et al., 2009; Santos et al., 2012). Available ages for detritic zircon point to a maximum age of $566 \pm 6.9 \mathrm{Ma}$ for the deposition of the Group (Bicca et al., 2013). A minimum age is constrained by basic intrusions dated at $535.2 \pm 1.1 \mathrm{Ma}$ (Almeida et al., 2010). Since these volcanic rocks intrude both the Santa Bárbara Group and the overlying Guaritas Group, the depositional age of the Santa Bárbara Group is probably several to tens of million years older than this minimum age.
The type-area of the unit, the Santa Bárbara Valley and nearby ranges is located in the Western Sub-basin (Fig. 2), with continuous exposures, more than 2600 m thick, of conglomerate, feldspathic and lithic sandstone and minor siltstone and mudstone. The Santa Bárbara Group is divided into five formations (Almeida, 2005; Fambrini et al., 2006), from base to top: the basal Estância Santa Fé Formation is composed mainly of conglomerate, sandstone, and minor siltstone; the Seival Formation includes interlayered siltstone and fine-grained sandstone with minor mudstone; the Serra dos Lanceiros Formation comprises sandstone and conglomeratic sandstone; the Arroio Umbu Formation is composed mainly of siltstone and sandstone, with minor conglomerate deposits at the eastern border of the basin; and the Pedra do Segredo Formation has sandstone and conglomerate deposits.

\section{Depositional systems}

In this paper, descriptions and interpretations of the depositional systems of the type area of the Santa Bárbara Group were based on the study of continuous stratigraphic sections of the main units, facies and architectural element analysis of selected outcrops, paleocurrent analysis, and geological mapping of the area at the scale of 1:50,000 (Fig. 1). Three main depositional systems have been recognized: Basin border conglomerates, interpreted as alluvial-fans; sandstone deposits, interpreted as fluvial channel-belts; and heterolithic fine-grained deposits, interpreted as fluvial floodplains. The description and interpretation of lithofacies are given in Table 1, and a summary of facies associations can be found in Table 2 .

\subsection{Basin border conglomerates}

\subsubsection{Description}

Conglomerate deposits (FA1a and FA1b, Tables 1,2) are found near the western border of the basin, in outcrops of the Estância Santa Fé Formation. Near the syn-sedimentary fault to the east of the sub-basin, conglomerate deposits are found only at the upper stratigraphic levels, being lateral equivalents to the Serra dos Lanceiros, Arroio Umbu and Pedra do Segredo formations. These deposits are characterized mainly

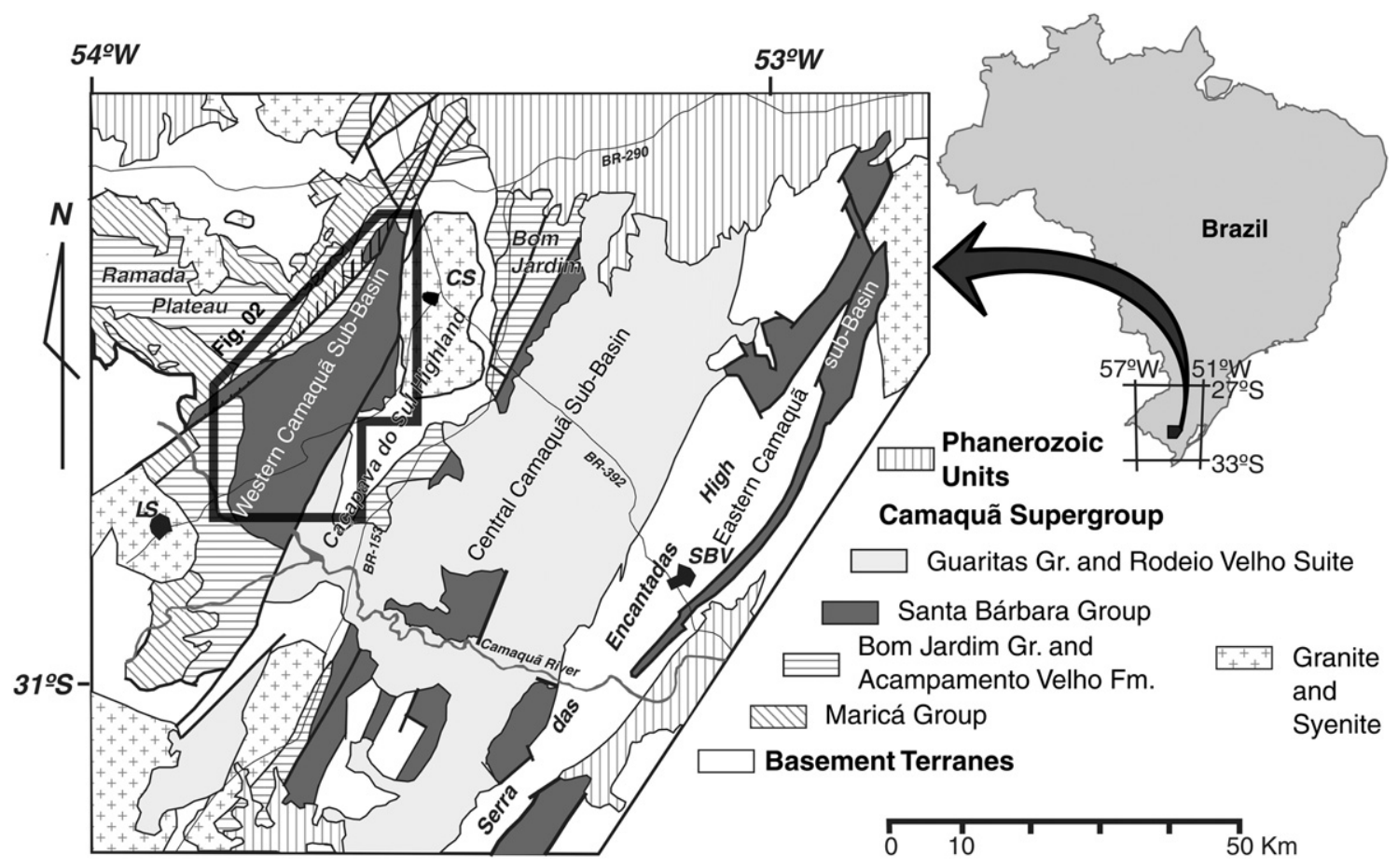

Fig. 1. Simplified geological map of the Camaquã Basin and surroundings. Localities: CS - Caçapava do Sul; LS - Lavras do Sul; SBV - Santana da boa Vista. Modified after Fragoso-Cesar et al. (2000). 

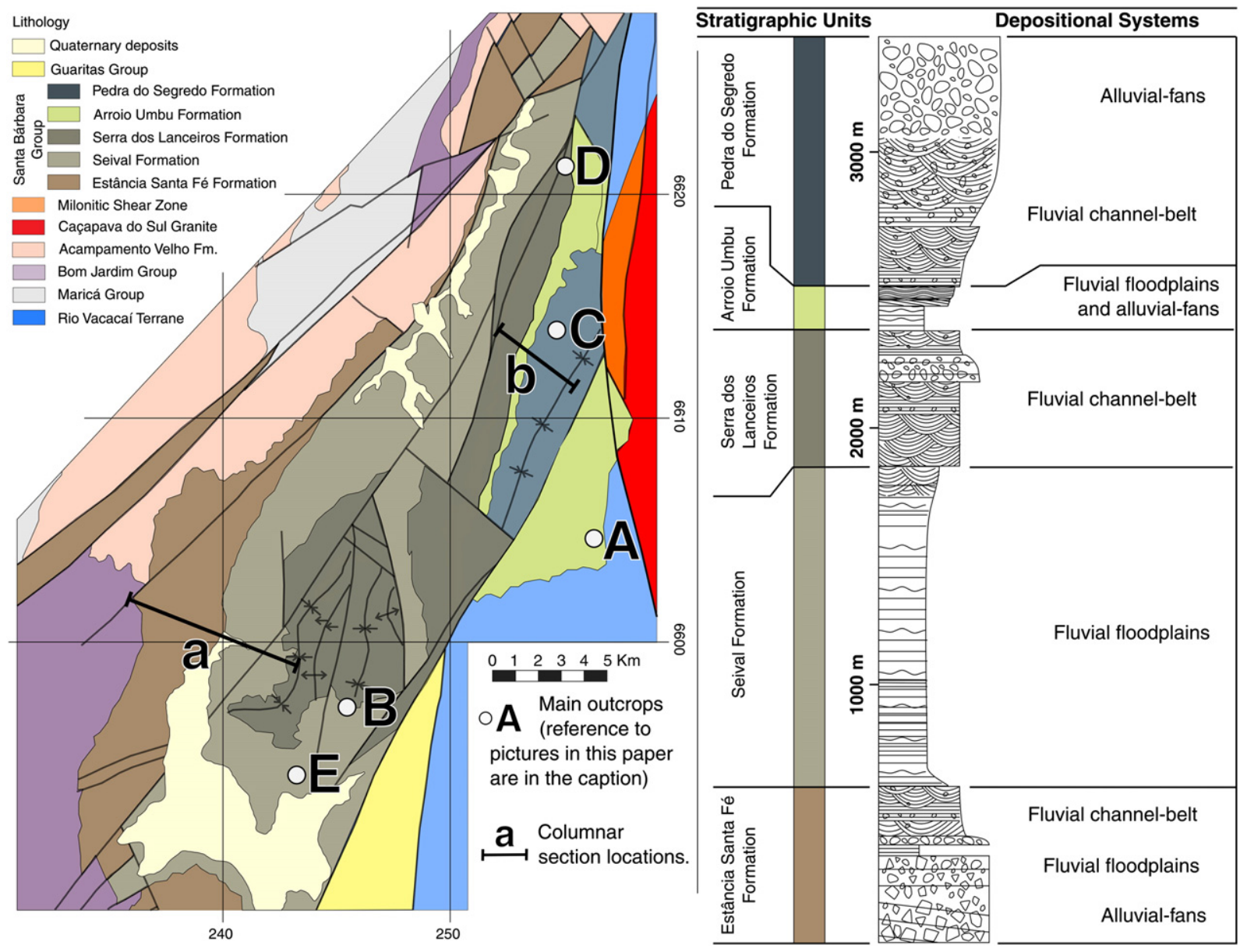

Fig. 2. Geological map of the Santa Bárbara Group in the Western Camaquã sub-basin, with composite stratigraphic section. Stratigraphic units and depositional systems are summarized after Almeida (2005) and Fambrini et al. (2006) and this paper. Points are outcrops described in this paper: A - Fig. 3C; B - Fig. 5; C - Fig. 6; D - Fig. 9; E - Fig. 11. Bars "a" and "b" represent different parts of the basin used to compose the stratigraphic section.

as interbedded planar stratified conglomerate and pebbly sandstone (C1), minor stratified conglomerate (C2) and planar stratified sandstone (S3), with local trough cross-stratified sandstone (S1) in isolated sets, most of them filling scours or small channelized bodies (Fig. 3A, B). Successions dominated by pebble-rich massive diamictite (D) occur locally (Fig. 3C), restricted to the basin-border fault.

In the most proximal exposures (near the basin margins), these conglomerates and minor diamictites show clasts up to $1.5 \mathrm{~m}$ in diameter, composed of lithologies found in the nearby basement (granite, granitic mylonite, phyllite) and of volcanic rocks that are no longer found proximally, most probably representing the exhumed volcanic counterparts of the Caçapava do Sul plutonism. Grain size decreases over a distance of 2-3 km basinward, and the conglomerate deposits are restricted to a belt a few kilometers wide, adjacent to the original basin-border faults.

The geometry of the larger-scale strata of the conglomerates and sandstones is difficult to evaluate due to the absence of laterally continuous surfaces and the homogeneity of facies, but the observation of larger exposures suggests the dominance of amalgamated tabular bodies a few meters thick, which are laterally continuous for more than $100 \mathrm{~m}$. The geometry of the massive diamictite bodies may be deduced from the distribution of clasts, with sharp variation of grain-size marking boundaries of individual beds and the concentration of larger clasts indicating the lateral limits of these bodies (Figs. 3E, 4B).

\subsubsection{Interpretation}

The association of interbedded planar stratified conglomerate and pebbly sandstone (C1) with stratified conglomerate (C2) and planar stratified sandstone $(\mathrm{S} 3)$ in laterally continuous tabular beds suggests deposition of bedload under unconfined water flow (Blair, 1999a, 1999b). Facies C1 closely resembles deposits interpreted by Blair (1999a) as the product of destabilization of antidunes under supercritical flow, suggesting that episodic high discharges were the main agents of deposition. Planar stratified sandstones are interpreted as the product of waning flow, possibly maintaining supercritical conditions due to water depth reduction. Minor trough cross-stratified sandstone (S1) filling scours or small channels (Fig. 4A) are thought to represent reworking of the major event beds by minor streams. The facies association and bed geometries, and their restricted occurrence near basin borders, suggest deposition in waterlain alluvial fans (e.g., Blair, 1999a, 1999b) (FA1a, Fig. 4A).

Massive Diamictites (D) with clasts up to $1.5 \mathrm{~m}$ in diameter (Fig. 3E) are interpreted as the product of debris flows in alluvial fans (e.g., Blair, 1999c) (FA1b, Fig. 4B). The local dominance of debris flows or sheetfloods may be a product of source areas more liable to chemical weathering and mud production (Blair, 1999b). Previous authors have also interpreted these successions as alluvial-fan deposits (e.g., Paim, 1994; Paim et al., 1995; Almeida, 2001, 2005; Borba and Mizusaki, 2003; Fambrini et al., 2006).

\subsection{Sandstone deposits}

\subsubsection{Description}

Sandstone (FA2, FA3 and FA4, Tables 1, 2) dominates both the Serra dos Lanceiros and the Pedra do Segredo formations, and is abundant in the upper stratigraphic levels of the Estância Santa Fé Formation. These deposits are mainly trough cross-stratified sandstone and pebbly 
Table 1

Description and interpretation of the sedimentary facies comprising the Santa Bárbara Group.

\begin{tabular}{|c|c|c|c|}
\hline Code & Facies & Description & Interpretation \\
\hline C1 & Conglomerate interstratified with sandstone & $\begin{array}{l}\text { Conglomerate interstratified with coarse sandstone, in centimetric to decimetric pairs. Grains } \\
\text { range from coarse sand to cobble, with rare boulders. Clasts are subangular to subrounded. } \\
\text { Layering is due to the alternation between sandy and pebbly strata. }\end{array}$ & $\begin{array}{l}\text { Products of the destabilization of upper-flow regime antidunes during sheetflood } \\
\text { events in alluvial fans (Blair and McPherson, 1994; Blair, 1999a). }\end{array}$ \\
\hline C2 & Stratified conglomerate & $\begin{array}{l}\text { Pebble to cobble conglomerate and pebbly sandstone in metric tabular layers with clasts } \\
\text { imbricated parallel to the A--B plane. Stratification is crude, marked by the alignment of } \\
\text { larger clasts. }\end{array}$ & Deposition from plane bed or low-relief bedforms in fluvial streams. \\
\hline C3 & Tabular cross-stratified conglomerate & $\begin{array}{l}\text { Conglomerate and pebbly coarse sandstone with medium scale tabular cross-stratification. } \\
\text { Clasts range from } 3 \text { to } 15 \mathrm{~cm} \text {, rarely up to } 20 \mathrm{~cm} \text {, and are subangulose to subrounded. }\end{array}$ & Migration of dunes and bars in bedload dominated fluvial streams. \\
\hline C4 & Massive conglomerate & $\begin{array}{l}\text { Massive, clast-supported conglomerate with larger clasts ranging from } 20 \text { to } 100 \mathrm{~cm} \text {, and } \\
\text { finer fraction of feldspathic coarse poorly sorted sandstone. Provenance is local and the clast } \\
\text { shape is a function of its lithotypes (rounded granites and angular low-grade metamorphics). }\end{array}$ & Matrix-poor non-cohesive debris flow (sensu Shultz, 1984). \\
\hline D & Massive diamictite & $\begin{array}{l}\text { Massive diamictite with clasts up to boulder size, in lenticular beds with variable amounts of } \\
\text { coarse fragments. Provenance is mono- to oligomitic. Rare occurrence, restricted to some } \\
\text { locations in the vicinity of the Caçapava do Sul High. }\end{array}$ & Debris flows. \\
\hline S1 & Trough cross-stratified sandstone & $\begin{array}{l}\text { Immature sandstone and conglomeratic sandstone with medium- to small-scale trough } \\
\text { cross-stratification. Thick homogeneous deposits with few conglomeratic levels. }\end{array}$ & Deposits of migrating subaqueous dunes with sinuous crests. \\
\hline S2 & Tabular cross-stratified sandstone & Feldspathic sandstone with tabular cross-stratification in thin to medium beds. & Deposits of migrating subaqueous dunes with nearly straight crests. \\
\hline S3 & Planar stratified sandstone & $\begin{array}{l}\text { Medium to coarse arkosean sandstone with plane-parallel lamination in decimetric tabular } \\
\text { layers, frequently with current lineation. }\end{array}$ & $\begin{array}{l}\text { Migration of low-relief ripples in upper-flow regime (bedload sheets sensu Best } \\
\text { and Bridge, 1992) }\end{array}$ \\
\hline S4 & Low-angle cross-stratified sandstone & $\begin{array}{l}\text { Fine- to medium-grained, well-sorted sandstone with low-angle cross-stratification in } \\
\text { decimetric to metric sets. Current lineation is common. }\end{array}$ & $\begin{array}{l}\text { Migration bedforms under flow in the transition between lower- and upper-stage } \\
\text { flows (Fielding, 2006). }\end{array}$ \\
\hline S5 & Massive sandstone & $\begin{array}{l}\text { Structureless feldspathic sandstone often with sparse granule and pebble. The facies occurs as } \\
\text { decimetric, and less frequently, metric layers, sometimes with contorted lamination marked } \\
\text { by mud films. }\end{array}$ & $\begin{array}{l}\text { Obliteration of primary hydrodynamic structures by liquefaction or pedogenic } \\
\text { processes. }\end{array}$ \\
\hline S6 & Sandstone with climbing ripples & Medium- to fine-grained micaceous sandstone with asymmetric climbing ripples. & Migration of current ripples with deposition both from traction and suspension. \\
\hline S7 & Sandstone with ripple marks & $\begin{array}{l}\text { Micaceous fine sandstone with preserved asymmetric ripple marks, often covered by mud } \\
\text { drapes. Sometimes on top of climbing ripple sets. }\end{array}$ & $\begin{array}{l}\text { Preservation of bedform (current ripple) by cessation of current and subsequent } \\
\text { covering by settling particles. }\end{array}$ \\
\hline $\mathrm{H}$ & Heterolithic mudstone and sandstone & $\begin{array}{l}\text { Intercalation between laminated sandstone and mudstone in millimetric to centimetric } \\
\text { layers with tens to hundreds of meters in width. Sandy strata are planar-laminated or show } \\
\text { ripple marks and sometimes climbing ripples, with deposition of mudstone in the ripple } \\
\text { troughs. }\end{array}$ & $\begin{array}{l}\text { Alternation between deposition from traction and from suspension in stagnant } \\
\text { water, due to intermittent flow. }\end{array}$ \\
\hline M1 & Structureless mudstone & $\begin{array}{l}\text { Sandy-mudstone and muddy-sandstone with mica and rare granules, frequently showing } \\
\text { slickensides. Concentrations of mud-clasts can be recognized, but elsewhere remnant } \\
\text { discontinuous or disrupted heterolithic lamination is present. }\end{array}$ & $\begin{array}{l}\text { Deposition of sand, silt and mud-clasts under tractive currents, with partial oblit- } \\
\text { eration of sedimentary structures by pedogenic processes. }\end{array}$ \\
\hline M2 & Laminated mudstone and fine sandstone & $\begin{array}{l}\text { Fine-grained lithotypes, mainly mudstone but also fine to very fine micaceous sandstone. } \\
\text { This facies occurs in centimetric to decimetric tabular layers. }\end{array}$ & Settling of fine particles from suspension. \\
\hline M3 & Mud-cracked mudstone & $\begin{array}{l}\text { Micaceous mudstone in millimetric to centimetric layers with mudcracks filled by medium to } \\
\text { coarse sand. Locally the edges of the mudcracks are curved, forming mud curls. }\end{array}$ & $\begin{array}{l}\text { Suspension and exposure of settling deposits, with consequent dessication of clay } \\
\text { minerals. It suggests short-lived subaerial exposure without significant erosion } \\
\text { before the deposition of the following bed. }\end{array}$ \\
\hline
\end{tabular}


Table 2

Description and synthesis of the facies associations found in the Santa Bárbara Group. Facies codes are given in Table 1.

\begin{tabular}{|c|c|c|c|}
\hline Code & Facies association & Description & Interpretation \\
\hline FA1a & $\begin{array}{l}\text { Plane bedded conglomeratic facies } \\
\text { association }\end{array}$ & $\begin{array}{l}\text { Homogeneous successions hundreds of meters thick, dominated } \\
\text { by facies C1, with C } 2 \text { and C } 3 \text { locally in scour-based, channelized } \\
\text { m-scale beds.' }\end{array}$ & $\begin{array}{l}\text { Recurrence of conglomeratic sheetfloods and minor reworking } \\
\text { of fan tops by channelized currents after the major floods. }\end{array}$ \\
\hline FA1b & $\begin{array}{l}\text { Diamictite and conglomerate facies } \\
\text { association }\end{array}$ & $\begin{array}{l}\text { Successions dominated by facies } \mathrm{C} 4 \text { and } \mathrm{D} \text {, with clasts that may } \\
\text { reach } 1 \mathrm{~m} \text { in diameter. The provenance is strongly controlled by } \\
\text { the most nearby source rocks, with volcanic and } \\
\text { metasedimentary rocks as the most common constituent. }\end{array}$ & $\begin{array}{l}\text { Cohesive and non-cohesive debris flow deposits. The process of } \\
\text { deposition is controlled by the availability of mud in the sources. }\end{array}$ \\
\hline FA2 & $\begin{array}{l}\text { Pebbly cross bedded sandstones facies } \\
\text { associations }\end{array}$ & $\begin{array}{l}\text { Homogeneous successions, hundreds of meters thick, } \\
\text { dominated by pebbly sandstone of facies S1 and to a lesser } \\
\text { degree, S2. Isolated, scour-based lenses of C } 3 \text { mark the base of } \\
\text { decimetric fining-upward successions with low-angle inclined } \\
\text { bedsets. }\end{array}$ & $\begin{array}{l}\text { The dominance of facies formed by migration of pebbly sand } \\
\text { dunes suggests deposition by fluvial streams. Additionally, the } \\
\text { scarcity of transitional to upper regime structures and the } \\
\text { occurrence of low-angle accretion surfaces suggest low variation } \\
\text { of discharge. }\end{array}$ \\
\hline FA3 & $\begin{array}{l}\text { Cross bedded conglomeratic facies } \\
\text { associations }\end{array}$ & $\begin{array}{l}\text { Alternations between deposits of facies } \mathrm{C} 2 \text { and } \mathrm{C} 3 \text {, with some C } 4 \\
\text { structureless deposits. }\end{array}$ & $\begin{array}{l}\text { Deposition of conglomerates in gravel bars in the most proximal } \\
\text { part of the fluvial system, in the transition from the alluvial fan } \\
\text { deposits. }\end{array}$ \\
\hline FA4 & $\begin{array}{l}\text { Cross bedded sandstone facies } \\
\text { associations }\end{array}$ & $\begin{array}{l}\text { Tens to hundreds of meters thick successions of cycles of sandy } \\
\text { cross-stratified facies (S1 and minor S2) passing to plane- } \\
\text { bedded sandstone (S3) and minor S4. }\end{array}$ & $\begin{array}{l}\text { Finner-grained fluvial systems characterized by high discharge } \\
\text { fluctuation, with deposition of lower-stage bedforms during the } \\
\text { peak flow (when channels are deeper) and subsequent deposi- } \\
\text { tion in transitional to upper-stage flow in fast, poorly confined } \\
\text { shallow currents during the waning of flood. It represents a } \\
\text { downstream equivalent to FA2. }\end{array}$ \\
\hline FA5 & Heterolithic facies associations & $\begin{array}{l}\text { Tens of meters thick successions composed of metric to } \\
\text { decimetric, scour-based cycles of sandy to pebbly cross- } \\
\text { stratified (S1 and S2) and plane bedded facies (S3 and S4), } \\
\text { passing to fine-grained deposits (mostly H) with the exposure } \\
\text { surfaces (M3) at the top of each cycle. Isolated metric bodies } \\
\text { composed mainly of intercalation of M2, S6 and H occur be- } \\
\text { tween some cycles. Facies M1 and S7 are also found. }\end{array}$ & $\begin{array}{l}\text { Deposition in floodplains, fed by episodic floods and } \\
\text { characterized by recurrent abandonment and subaerial } \\
\text { exposure of broad areas, and local preservation of small ponds in } \\
\text { depressions, where settling of fine particles took place. }\end{array}$ \\
\hline
\end{tabular}

sandstone (S1), planar (C2) and cross-stratified (C3) conglomerate (Fig. 3D), with minor planar stratified (S3) and low-angle crossstratified fine-grained sandstones (S4, Fig. 5). S1 sandstone is organized in cosets, each composed of 2 to 4 sets of decimeter-scale cross beds (Fig. 3E), whose bounding surfaces have gentle downstream and lateral dips. Bounding surfaces of cosets are marked by abrupt changes in thickness of sets, orientation of cross-beds and grain size, and also dip gently (Fig. 3F). These are often erosional, sometimes preceded by scours filled with cross-bedded conglomerates (C3). In exposures transverse to the basin axis the surfaces are sometimes convex up, delineating large scale lenticular bodies, locally cut by and onlapping concave-up higher-order surfaces (Fig. 6).

The large-scale geometry of the sandstone and conglomerate bodies is difficult to recognize, mostly due to the abundance of low-hierarchy erosional surfaces and the homogeneity of facies. Nevertheless, observation of large exposures suggests that the architecture is dominated by several meter thick units which are tabular and laterally continuous for more than $100 \mathrm{~m}$ in directions near parallel to the main dips of the cross-beds, and more lenticular in directions perpendicular to that (Fig. 6A, B). Paleocurrent directions obtained from cross-strata point to a main northward axial flow and basin-border transverse tributary flow from both east and west (Almeida, 2005).

\subsubsection{Interpretation}

The dominance of homogeneous successions of trough crossstratified sandstone and pebbly sandstone (S1) in FA2 (Fig. 7A) indicates the migration of sinuous-crested (3D) subaqueous dunes under subcritical flow. The uniformity of this facies association, interrupted only by the rare occurrence of planar stratified sandstone attributable to transcritical or supercritical flow (S4), suggests the preferential preservation of channel and fluvial bar deposits, and the presence of accretion surfaces implies that succeeding flood events resulted in increments of macroforms, rather than erosion of previous deposits and rearrangement of channels and bars. Tabular to lenticular geometries indicate amalgamation of broad and shallow channels, most probably with braided patterns. Conglomerates with planar stratification (C2) or cross-beds (C3) of FA3 (Fig. 7B) are interpreted as gravel bars and mark the advance of coarse-grained clastic wedges basinward, possibly due to decreased accommodation in the basin. The interpreted environment is of a braided river, with the more conglomeratic FA3 representing proximal fluvial deposits, and the FA2 representing its distal counterpart. Homogeneous successions of fine to medium-grained, mostly planar and low-angle cross-stratified sandstone (S3) in FA4 (Fig. 7C) indicate deposition on upper parts of broad, low relief bars (Miall, 1978; Fielding et al., 2009). Their dominance in the transition between mud-rich successions and trough cross-stratified sandstones suggests the existence of an area of shallow flow over broad bars which flanked the main channel-belt and had increments toward the floodplain, forming channel wings (Alexander and Fielding, 2006) that acted in a similar way to levee deposits in modern fluvial systems. The frequent scour fills in these planar stratified deposits represent erosional features analogous to crevasse channels at younger fluvial systems. Previous authors have interpreted these successions as braided river deposits (e.g., Paim, 1994; Paim et al., 1995; Almeida, 2001, 2005; Borba and Mizusaki, 2003; Fambrini et al., 2006).

\subsection{Heterolithic fine-grained deposits}

\subsubsection{Description}

Heterolithic relatively fine-grained deposits (FA5) dominate both the Seival and the Arroio Umbu formations, and gradually pass into sandstone deposits from the Serra dos Lanceiros and to the Serra do Segredo formations respectively.

These successions are characterized by interbedded sandstone and mudstone (Fig. 8A), with abundant mudcracks (M3). Planar lamination (S2, Fig. 8B), trough cross-beds (S1), ripples and ripple cross-lamination (S6, Fig. 8C, D) are the most common structures in the sandstones. Layers of silty-sandstones and sandy-siltstones with variable degrees of loss of sedimentary structures are also common, often presenting slickensides (M1), and even a blocky structure (Fig. 8E).

Tabular bodies of mudstone, structureless silty sandstone and ripple cross-laminated micaceous fine sandstone $(\mathrm{H})$, with minor planar stratified sandstone intercalations, are 0.5 to $1.5 \mathrm{~m}$ thick (Fig. 9), and laterally continuous for more than $100 \mathrm{~m}$. Interbedded and interlaminated sandstone and mudstone show abundant sand-filled mudcracks at several scales (Fig. 8F), even in millimeter thick mudstone films. Discontinuous 

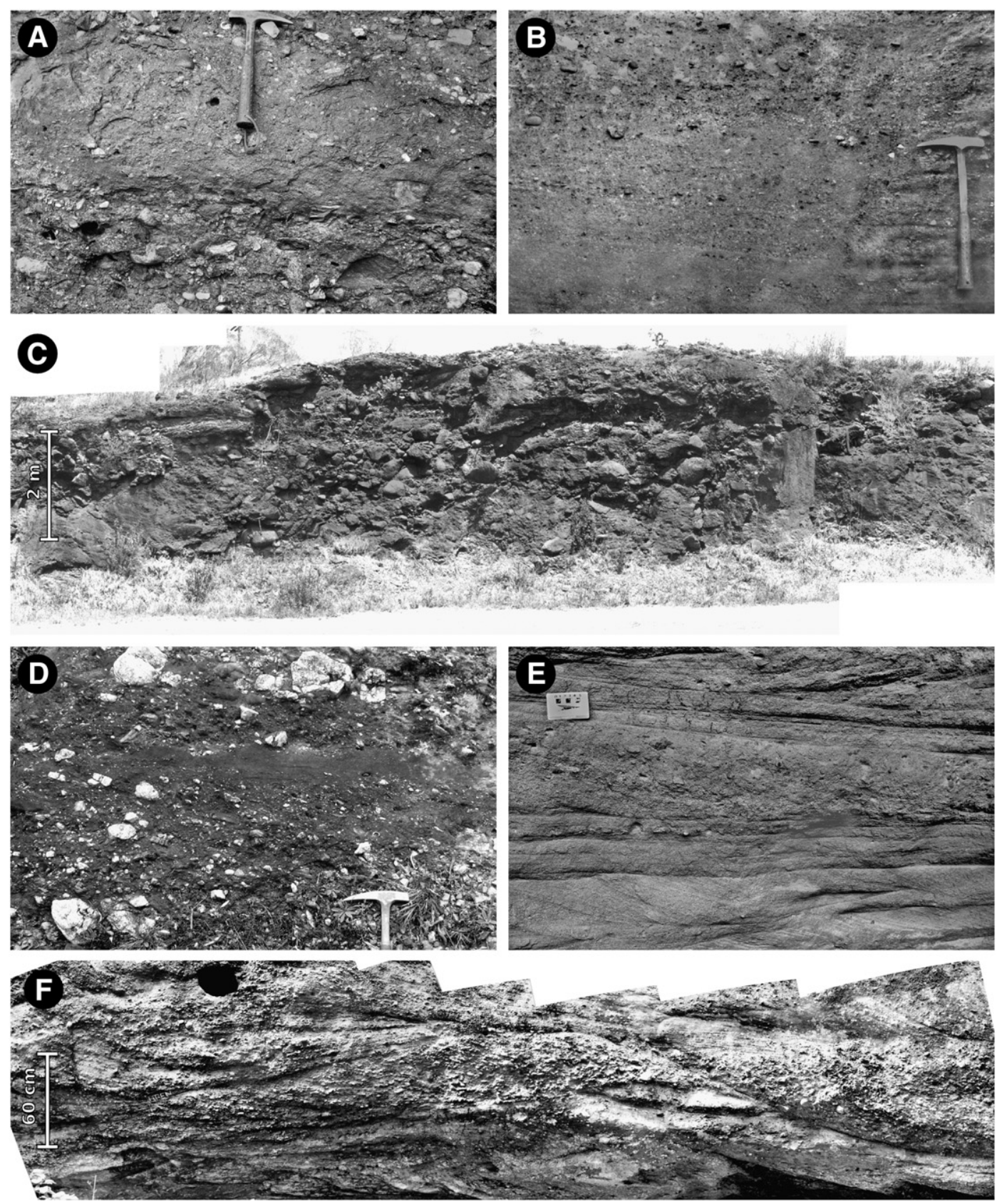

Fig. 3. Photos of selected facies. (A) Facies $\mathrm{C} 1$ with interstratified conglomerate and sandstone; (B) facies C2, showing crude stratification in conglomerate; (C) conglomerate of facies C4 disposed in crudely defined lenticular bedding; (D) layers of facies C3 with tabular stratification interbedded with S3 sandstone; (E) layers of sandstone of facies S1, S2 and S3 and conglomerate of facies C3. Card for scale is $7 \mathrm{~cm}$ wide; (F) intercalation of conglomeratic sandstones of facies S1 and S3, a common feature in facies association FA3.

patches of interlaminated strata are locally found in structureless, slickenside-bearing silty-sandstone and sandy-siltstone (Fig. 8G). Other micaceous silty-sandstone and sandy-siltstone show sand-sized to granule-sized mud-clasts.

Lenticular bodies of planar stratified fine-grained sandstones are often 10 to $40 \mathrm{~cm}$ thick and continuous for more than $50 \mathrm{~m}$, showing planar lower erosional surfaces (Fig. 9), whereas cross-bedded sandstones are restricted to bodies with concave-up lower erosional surfaces (Fig. 8H), 20 to $50 \mathrm{~cm}$ thick and pinching out in less than $15 \mathrm{~m}$ in transverse sections. Longitudinal sections of these cross-bedded sandstone bodies are laterally continuous for several tens of meters, and sometimes reveal partial preservation of bedforms, draped by cracked mudstone (Fig. 10). The transition of these deposits into FA1 and FA3 shows a gradual decrease in the frequency and thickness of finergrained facies.

\subsubsection{Interpretation}

The abundance of mudstone, often mud-cracked, indicates recurrent stagnation of flow, with settling of fine particles followed by exposure and dessication (e.g., Hadlari et al., 2006; Fralick and Zaniewski, 2012; Fig. 11). The presence of slickensides associated with the structureless sandy-siltstone (M1) suggests some degree of pedogenesis (e.g., Retallack, 1992, 2001), but without the obvious features of more modern paleosols, like root traces, being very similar to other Ediacaran examples (Kolesnikov et al., 2012; Retallack, 2012, 2013), which show clay enrichment, disruption of sedimentary structures and blocky texture. Ripples and climbing ripple cross-lamination indicate subcritical decelerating flow, whereas planar stratified finegrained sandstone is interpreted as the result of transcritical to supercritical flow. Channel-like small bodies of trough cross-bedded sandstone developed after small-scale erosion of substrate suggests the 


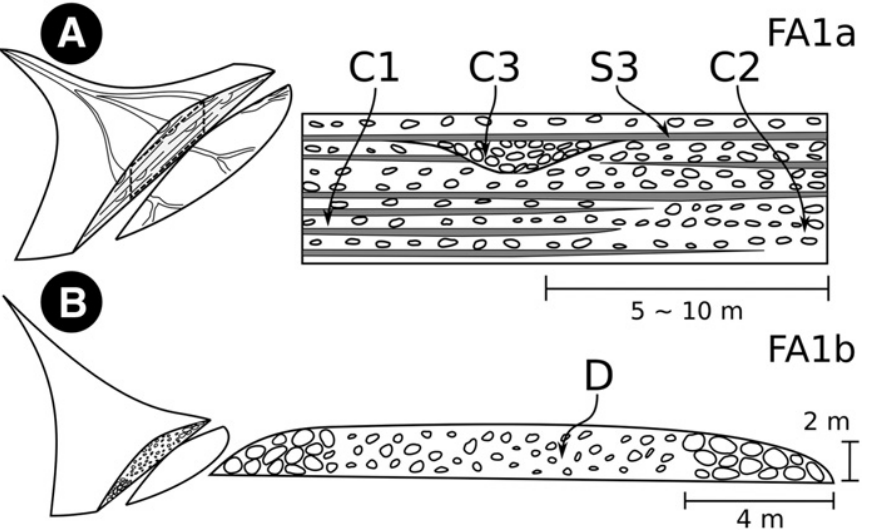

Fig. 4. Schematic diagram of alluvial-fan deposits from facies associations FA1a and FA1b. (A) FA1a, with conglomerate deposits of facies C2 interbedded with sandstone and conglomerate of $\mathrm{C} 1$ and thin sandstone layers of facies $\mathrm{S} 3$. Note the erosional scour below C3 facies; (B) FA1b facies association, showing idealized convex form of alluvial fan lobe, inferred from clast distribution.

existence of small-scale channels reworking the top of sandstone bodies (e.g., Bristow et al., 1999). The intercalation of the above described facies, sometimes comprising cycles of shallowing water-depth, suggests high discharge variation and recurrent periods of stagnation, exposure and pedogenesis.

The interpreted environment is that of a floodplain associated with an adjacent channel-belt and basin-border alluvial-fans. These floodplains were subject to periodic flooding and drying, with incipient pedogenesis, and were cut by small-scale channels of an ephemeral nature (Fig. 11).

Alternative interpretations of lacustrine deltas for the same successions (e.g., Paim, 1994; Paim et al., 1995; Borba and Mizusaki, 2003) are based on the recognition of progradational stacking patterns on both the Seival and the Arroio Umbu formations. Paim (1994) recognized the ephemeral nature of these lakes and correlated high-stage periods with the input of sand, and low-stage periods with settling of fine- grained particles and drying out. The two main arguments to refute this interpretation are: (1) the coarsening-upward pattern, interpreted by Paim (1994) as resulting from deltaic progradation, is given by an increase in frequency and thickness of fluvial stream facies (mostly trough cross-bedded and planar stratified sandstone), and not of subaqueous sand-bodies attributable to delta front advance; and (2) these subaerial stream deposits are interbedded with fine-grained deposits which present evidence of subaerial exposure and incipient pedogenesis throughout the whole succession, and therefore there was no long-lasting water body to be filled by large-scale progradation.

The interpretation of a tide-dominated estuarine environment for these successions (Almeida, 2001; Fambrini et al., 2006) was based on the arguments formulated by Paim (1994) for a major water-body filled by progradation of deltaic facies, coupled with the misinterpretation of intraclast-rich trough cross-bedded sandstones as tidal bundles. Detailed observation of the key outcrops and petrography of samples later revealed that the supposed mud films were in fact levels of concentration of small tabular mud clasts on the foresets of cross-beds, which looked like continuous laminae in altered exposures.

\subsection{Paleoenvironmental reconstruction}

The large-scale architecture of the Santa Bárbara Group in its type area is interpreted from detailed geological mapping, aided by the interpretation of air photographs on the scale of 1:25,000. In spite of the presence of localized faults and tilting of the beds, kilometer-scale lateral variation of facies associations can be recognized, indicating the coexistence of channel-belts, floodplains and alluvial fans. This contemporaneity of depositional environments is observed in the transition from the Arroio Umbu Formation floodplain into alluvial fan and channel-belt facies of the Pedra do Segredo Formation channel-belt facies, as well as in the passage from the upper part of the Estância Santa Fé Formation to the Seival Formation. Even where the scale of lateral transition does not allow its recognition through geological mapping, the gradual superposition of channel-belt dominated successions over floodplain successions strongly suggests their coexistence on the same alluvial plain (Fig. 12).
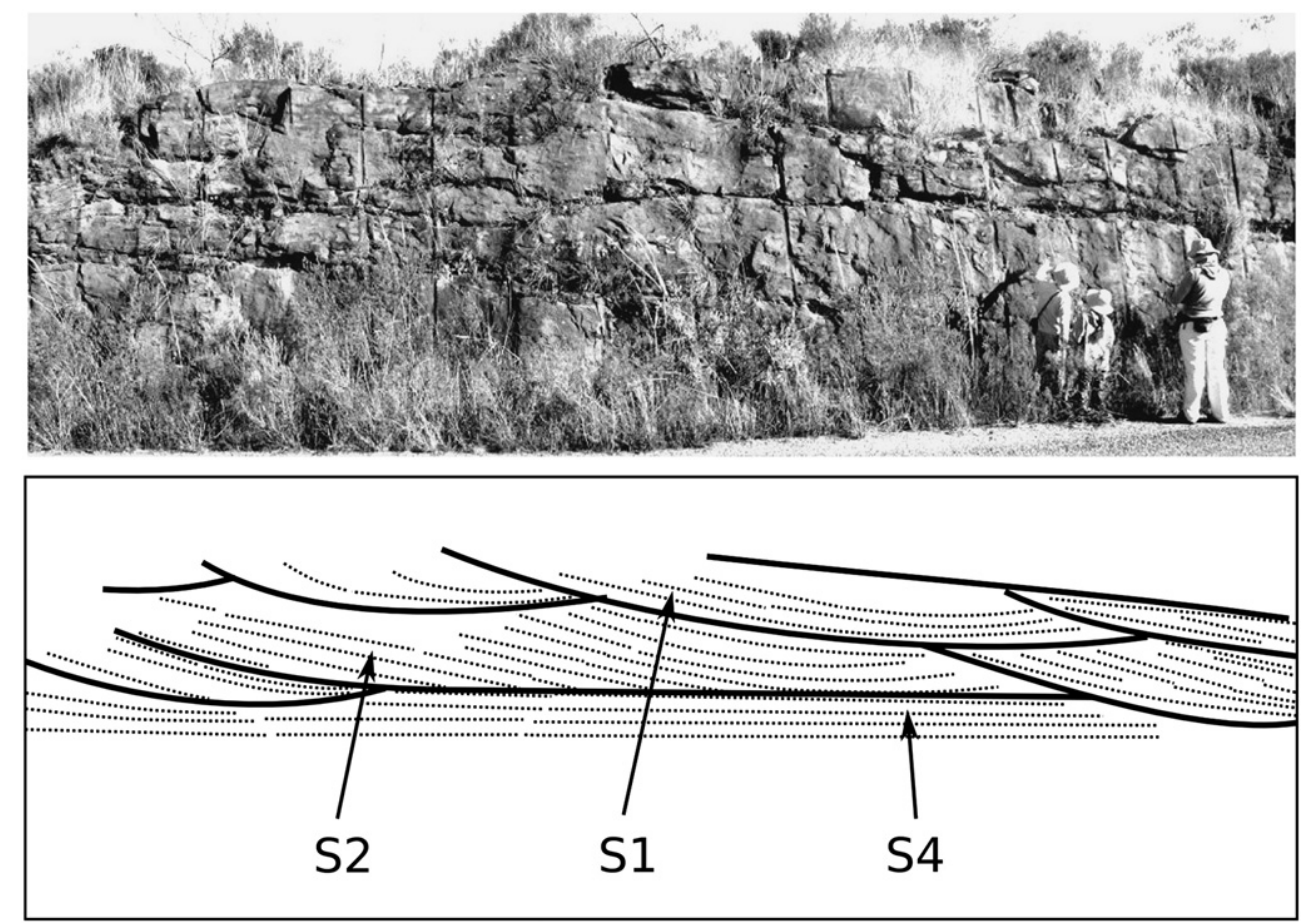

Fig. 5. Outcrop and line drawing of sandy fluvial deposits facies association (FA4), presenting lenticular layers of trough and tabular cross-stratified sandstones (facies S1 and S2), with minor planar stratified and low-angle cross-stratified sandstone deposits (facies S3 and S4), Serra dos Lanceiros Formation. 

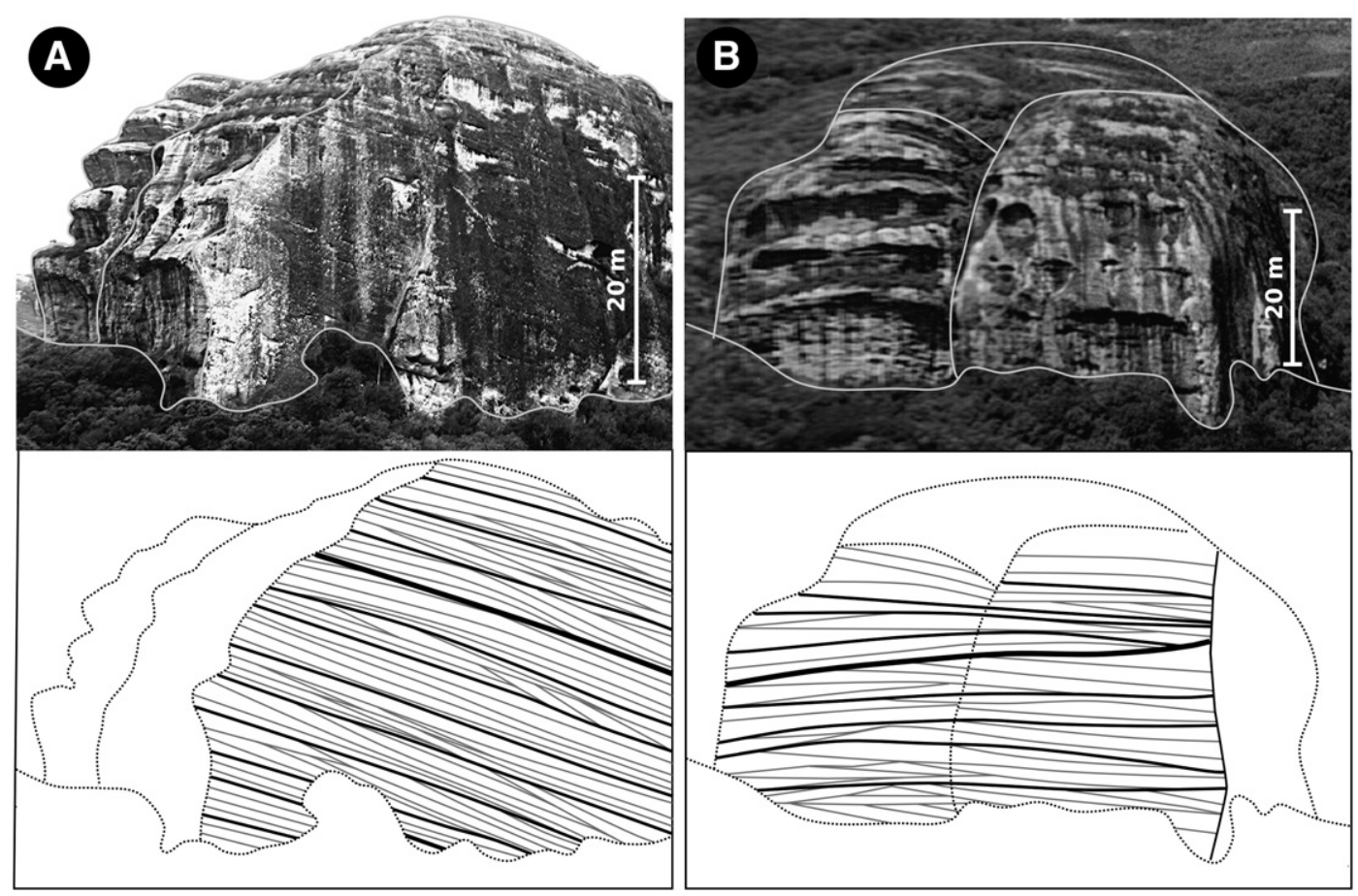

Fig. 6. Large-scale geometry and line drawing interpretation of sandstone deposits of facies association FA3. (A) East-west face, perpendicular to the basin-border, with sandstone layers presenting a more tabular geometry; (B) north-south face, parallel to the basin axis, showing large-scale lenticular architecture, Pedra do Segredo Formation.

Successions dominated by FA1a and FA1b, interpreted as alluvial fan deposits, are either truncated basinward by sandy fluvial deposits of FA2 (the Serra dos Lanceiros and Pedra do Segredo Formations) or pass gradually into sand-mud successions of FA5, interpreted as floodplains (Seival and Arroio Umbu formations). Successions dominated by FA2 dominate the uppermost parts of both the Serra dos Lanceiros and Pedra do Segredo Formations and occur in the transition from FA1a to FA3 dominated successions of the Estância Santa Fé Formation (FA2).

Successions dominated by FA3, interpreted as braided channel deposits, are homogeneous and several hundred meters thick. In the
Estância Santa Fé Formation they grade from basin-margin conglomerates, mostly FA1a, and transition upward and basinward into finergrained successions. By contrast, in both the Serra dos Lanceiros and the Pedra do Segredo Formations, successions dominated by FA3 are part of coarsening-upward trends, grading from the interpreted floodplain deposits of the Seival and Arroio Umbu formations (FA5) and transitioning upward into conglomeratic strata of FA2 (Fig. 4F).

The passage from mud-rich floodplain deposits of FA5 into the trough cross-stratified fluvial succession (FA3) is characterized by the presence of successions dominated by FA4, rich in planar stratified

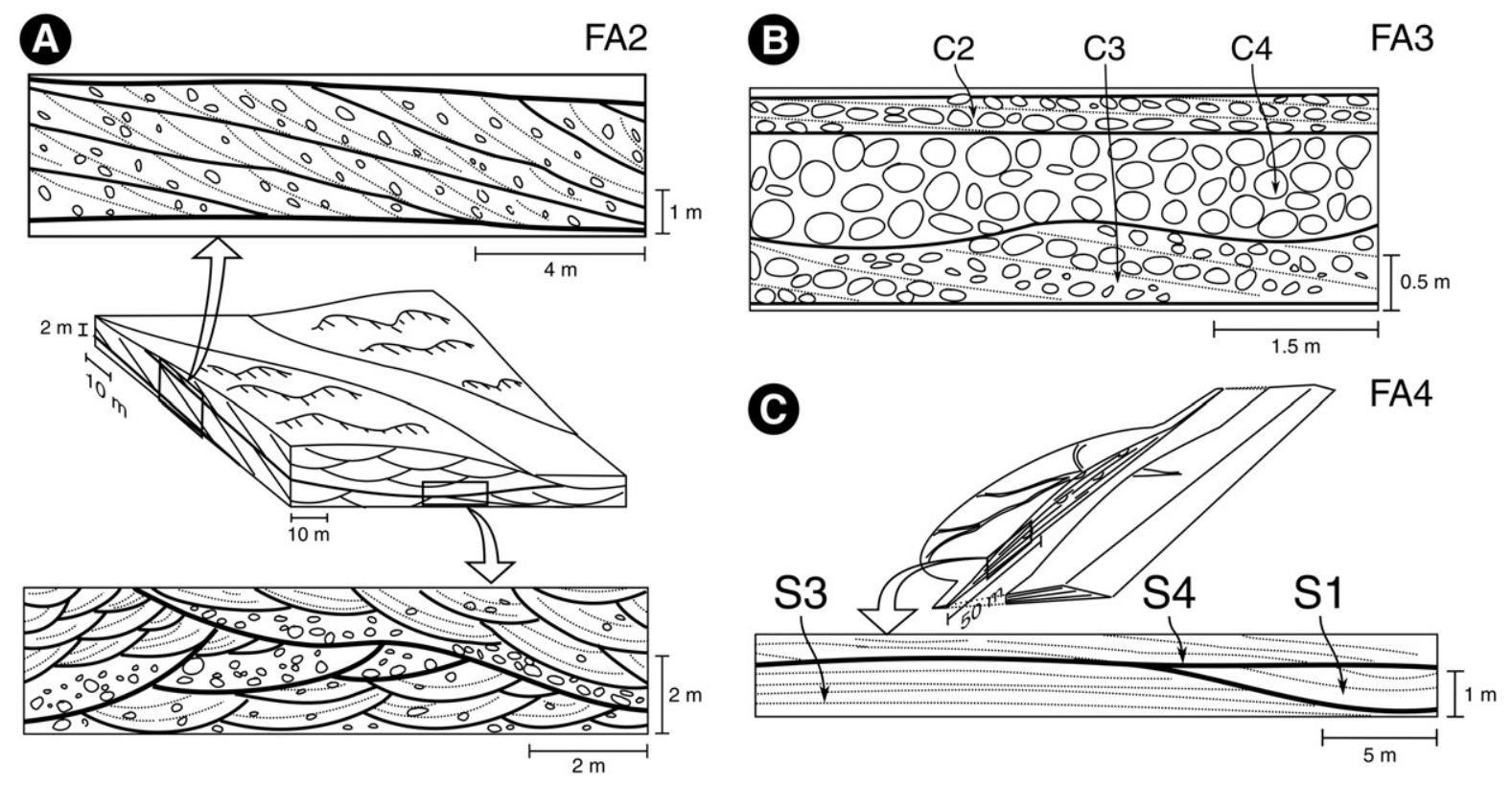

Fig. 7. Cartoons summarizing main features of the fluvial deposits of facies associations FA2, FA3 and FA4. (A) Longitudinal and transverse profiles of FA3. Thicker lines represent erosional bounding surfaces to mesoforms, thin lines represent downstream accretion surfaces, and dot lines are trough cross-bedding; (B) conglomerate deposits of FA2, with thicker lines separating different facies and thin lines indicating cross-stratification within facies C2 and C3; (C) idealized macroform of FA4, with detail of the relation between sandstone facies. Thicker lines separate different facies and thin lines represent depositional surfaces. 

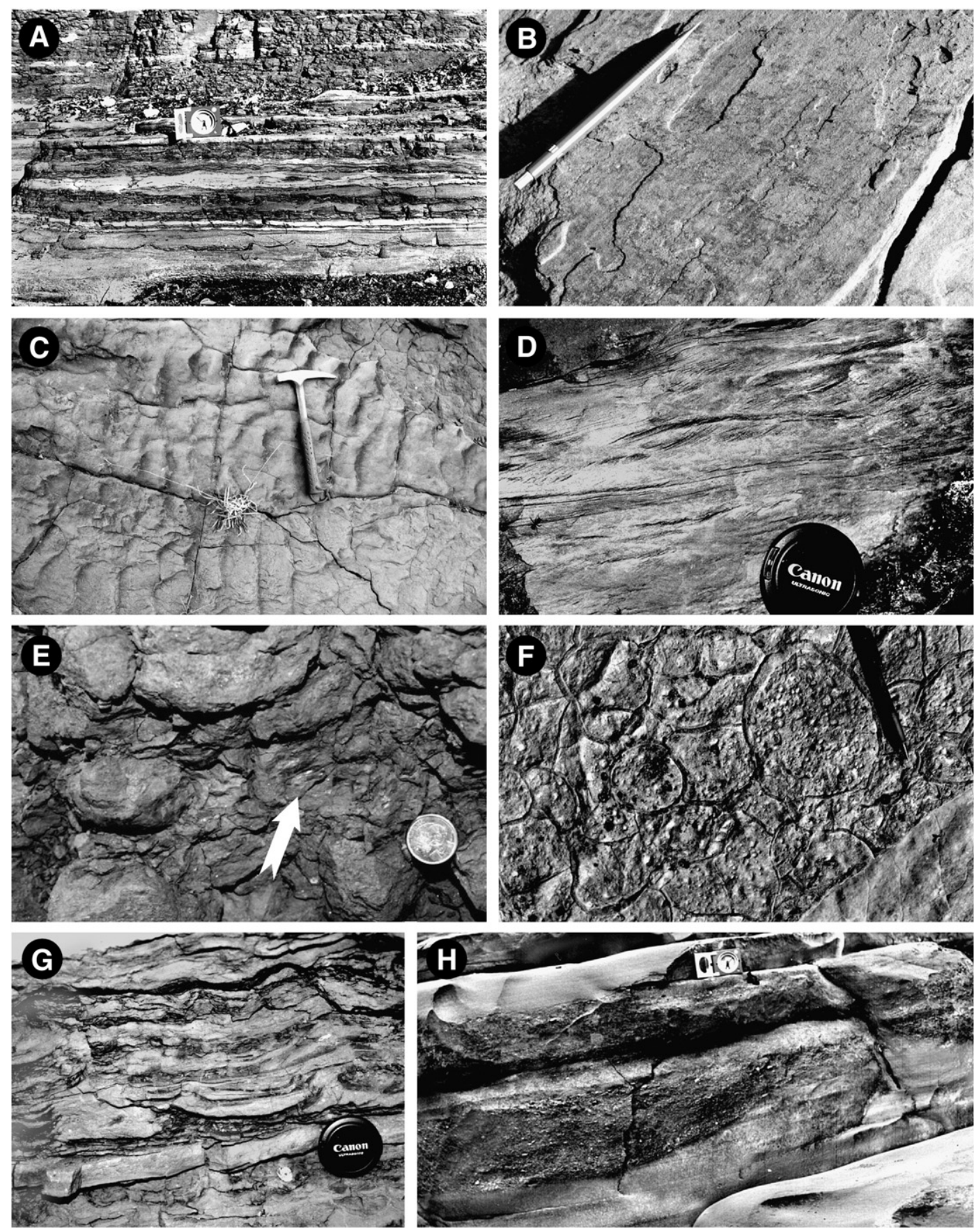

Fig. 8. Selected facies photos. (A) Detail of laminated sandstone and siltstone layers of facies M2, with massive mudstones of facies M1 on the top of the picture and some mud curls in the bottom; (B) detail of parting lineation in sandstone of facies S3, in plan view; (C) rippled sandstone in plan view; (D) climbing ripples of facies S6; (E) detail of one of the paleosols in M1 facies, with blocky structure and slickensides (in the center of the picture, pointed by an arrow); (F) plan view of mudcracks of facies M3 with raindrop imprints; (G) detail of facies M1, with partial preservation of sedimentary features of facies M3; (H) outcrop of sandy deposits of floodplain facies association (FA5), with planar stratified sandstones (S3) cut by trough cross-stratified sandstone (S1), at the center of the picture.

fine sandstone. These deposits are most likely associated with the topographic gradient between the alluvial ridge and the floodplains (Fig. 12), occupying a position analogous to vegetated levees. Floodplain deposits (FA5) are found mostly north of coeval channel-belt deposits, and thus in the direction of sedimentary transport inferred from paleocurrent data, being preserved laterally and downcurrent from the larger channel-belt. In this sense, the facies distribution of the Santa Bárbara Group resembles the one predicted by the Distributary Fluvial System Model (DFS) (Nichols and Fisher, 2007; Fordham et al., 2010; Hartley et al., 2010; Weissmann et al., 2010), with a marked decrease in channel size and increase in the preservation of floodplain deposits downcurrent, suggesting a loss of discharge in single channels due to a distributary pattern. Nevertheless, the lateral transition from alluvial fan deposits directly into floodplain deposits makes it difficult to determine whether the small channels cutting through the floodplains are fed from larger channels upcurrent, overbank floods or distal parts of alluvial fans.

\section{Discussion}

Floodplains are considered as strips of land that border river channels and are inundated during floods (Bridge and Demicco, 2008). Since pre-vegetation fluvial systems are expected to have had large discharge variations causing episodic widening of fluvial streams (Wolman 

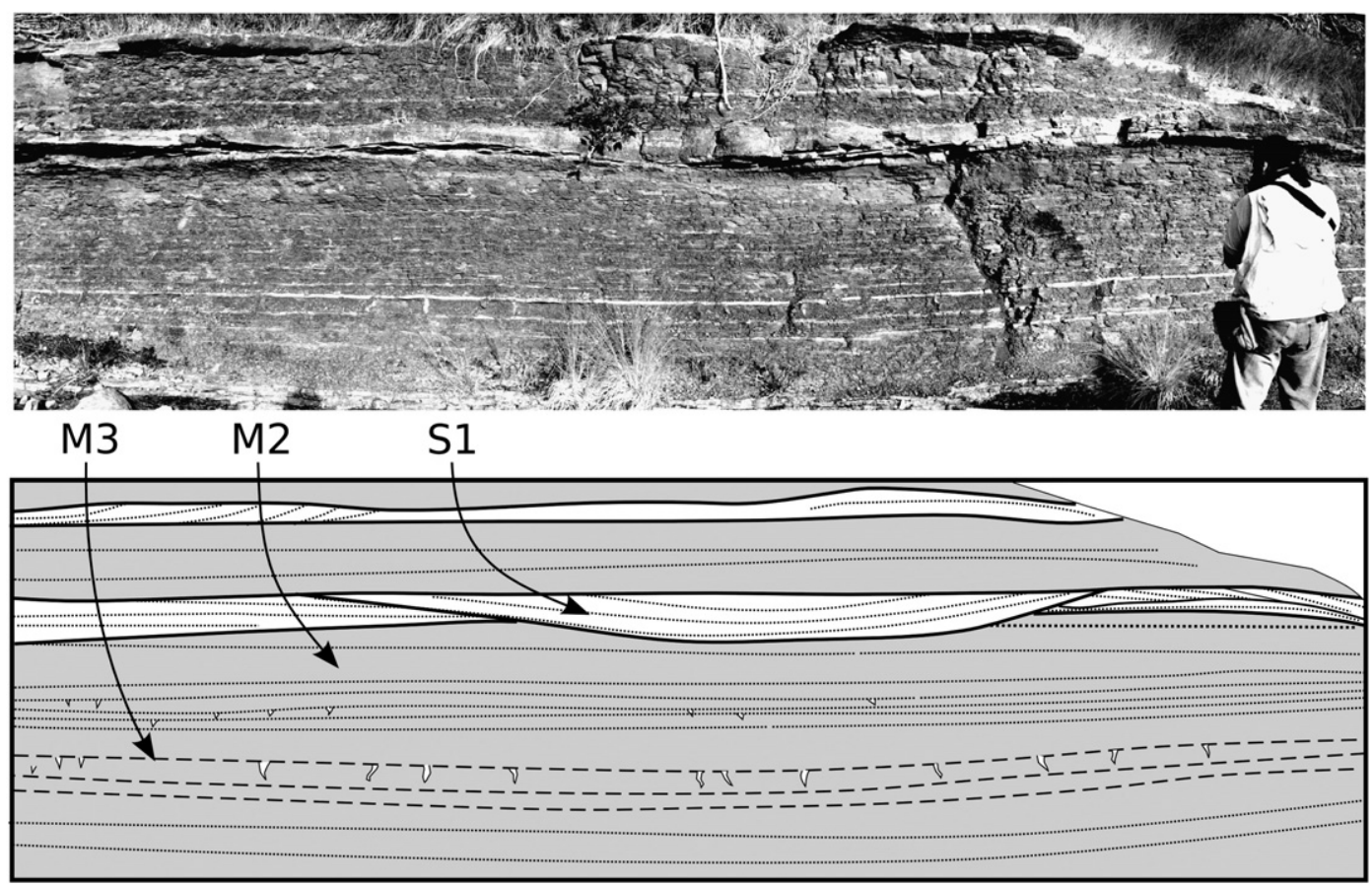

Fig. 9. Fine-grained deposits and interpreted line drawings of the fluvial floodplain facies association (FA5), which shows a succession of interbedded mudstone and siltstone of facies M2, with frequent mudcracks (layers of facies M3). The sandstone layer of facies S1 shows a broad trough geometry, with slightly erosional base, Arroio Umbu Formation. Mudstone facies are in gray and sandstones in white. Dashed lines represent well cemented fine sandstone overlying mud-cracked siltstones, thin lines are depositional surfaces and thick lines delimit different facies. "V" shaped symbols are wide shrinkage cracks filled with fine sand (facies M3).

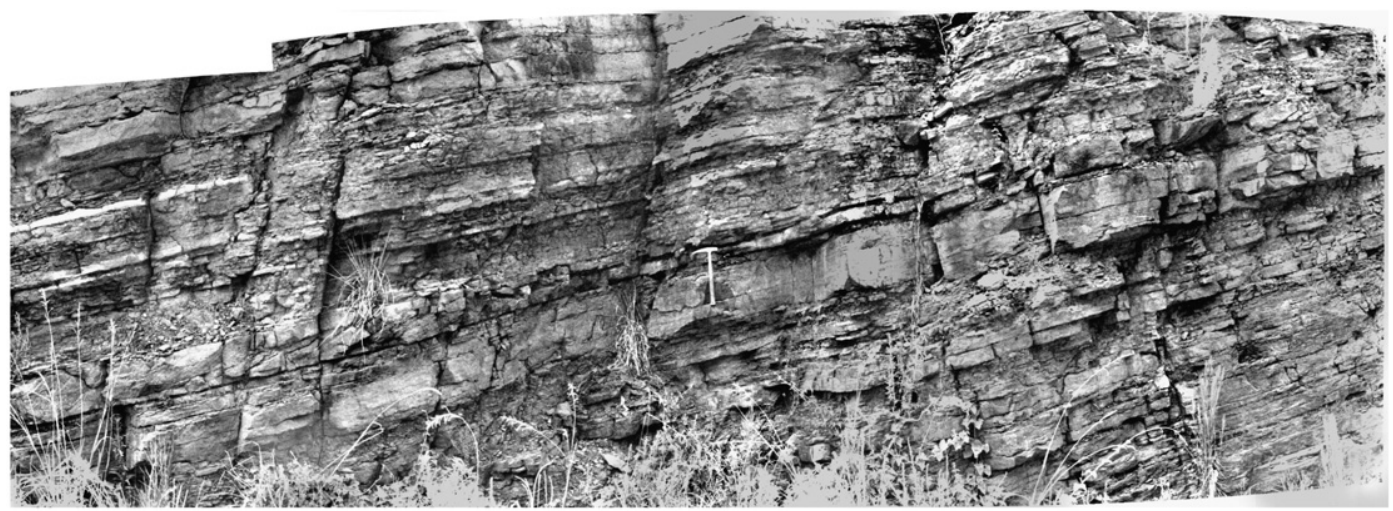

S1

$\mathrm{M} 2+\mathrm{M} 1$

M3

S3

S4

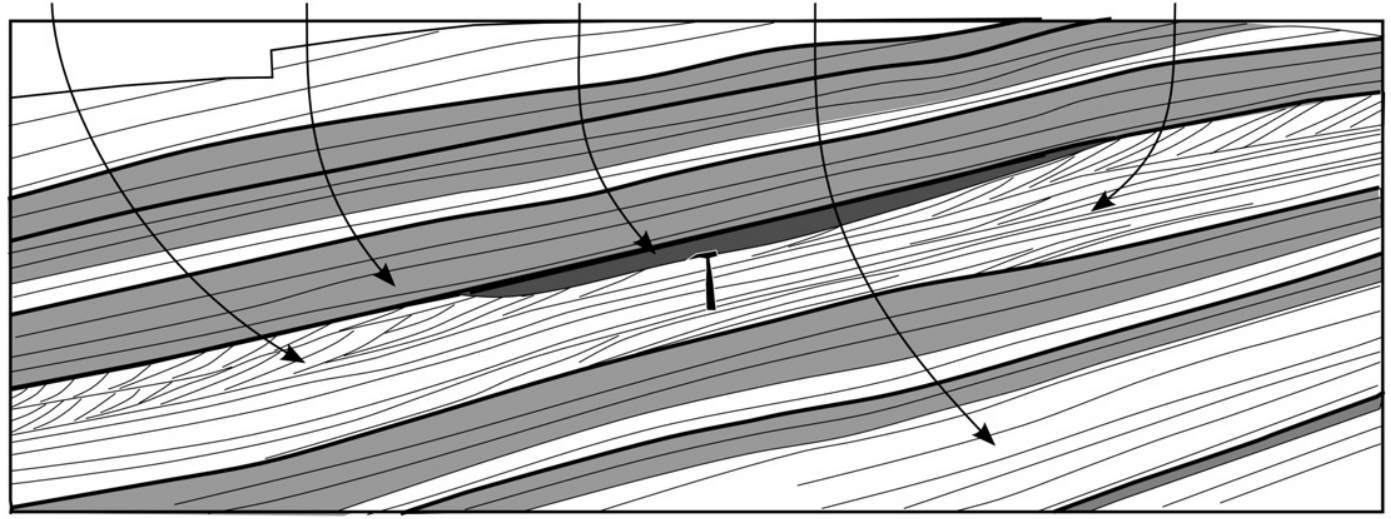

Fig. 10. Outcrop and line drawing showing deposits of the fluvial floodplain facies association (FA5), with intercalation of laminated and minor massive mudstone (facies M2 and M1) with deposits of planar stratified sandstone (facies S3), low-angle cross-stratified (facies S4) and trough cross-stratified sandstone (facies S1), the latter showing preservation of bedform (center of the picture), with deposition of mudstone between the sand dune forms, Seival Formation. Thicker lines represent progressively higher-order surfaces. Mudstone facies are in gray and sandstones in white. Thin lines are depositional surfaces, while thick lines represent surfaces of prolonged subaerial exposure. Hammer in the center of picture is $30 \mathrm{~cm}$ long. 
FA5

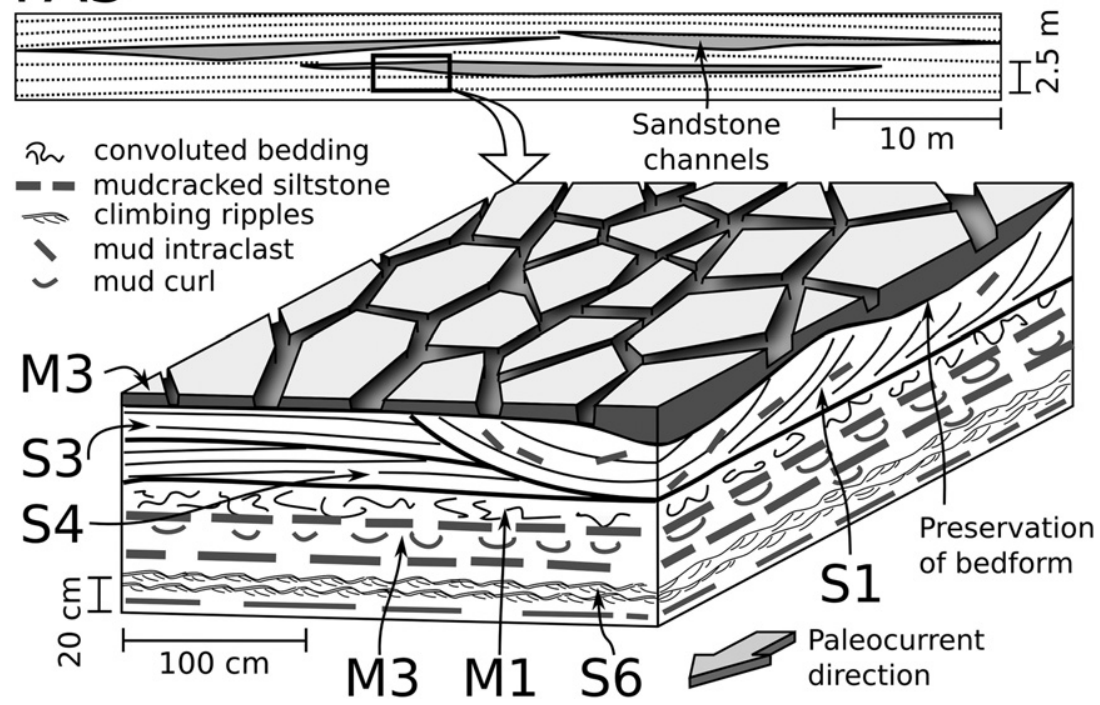

Fig. 11. Cartoons depicting the geometry of mudstone deposits and sandstone ribbons of FA5, with detail of the relation among facies in the block diagram.

and Brush, 1961), an area adjacent to the channel-belt would be characterized by ephemeral stream flow. In the absence of vegetated levees and due to the expected stream widening, the suspended load of the major channel floods would possibly reach not only these marginal areas, but also the bedload (e.g., Ramaekers and Catuneanu, 2004). In this way, small channels cutting the bars that flanked the channel-belt (wings, sensu Friend et al., 1979; Hirst et al., 1993) could bring coarse sand and even granules to the floodplain, which would therefore be markedly coarser-grained than their modern counterparts. Alternatively, in the Santa Bárbara Group, the recognized small channelized bodies cutting floodplain facies could be interpreted as the result of a distributary pattern of flow, with marked reduction of discharge in single small channels toward distal areas. Nevertheless, the episodic nature of the flow in those small channels, which are frequently filled by a single set of cross-strata covered by a mud drape, locally preserving the form of subaqueous dunes, contrasts with the architecture of the channel-belt deposits, which show meter-scale bars with internal accretion surfaces.

Models for the dynamics of pre-vegetation fluvial channels (Schumm, 1968; Cotter, 1978; Long, 2004) predict that the absence of land plants would imply reduced infiltration of rain water, thus

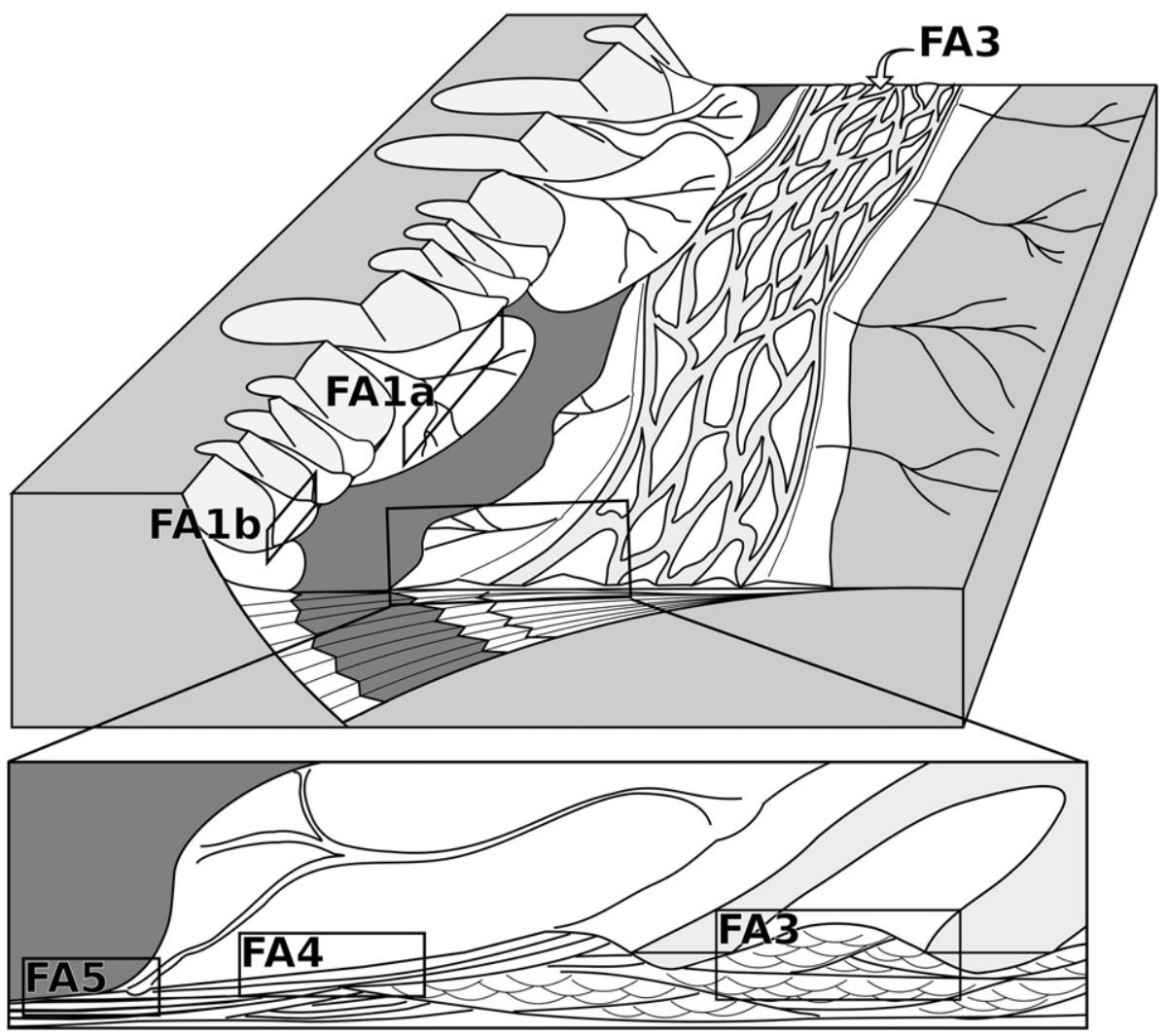

Fig. 12. Block diagram summarizing the main features of the interpreted paleoenvironment for a given moment of the Santa Bárbara Group evolution. The highlighted rectangles represent facies association detailed in Figs. 4, 7, 11 . 
resulting in higher runoff rates and greater discharge variation of fluvial systems (Long, 2006; Davies and Gibling, 2010; Davies et al., 2011). In light of these models, different authors have suggested that prevegetation fluvial systems would have behaved as ephemeral streams (e.g., Eriksson et al., 1998, 2006; Long, 2006). Nevertheless, the dominance of meter-scale bar deposits in the Santa Bárbara Group, while not being conclusive about the water discharge regime, indicates that flow variation was not large enough to rearrange the whole morphology of bars and channels during individual floods.

On the other hand, the intrinsic ephemeral nature of floodplain deposition (Bridge, 2003) brings uncertainties regarding paleoclimate interpretations based on fluvial style alone. If distal areas of a fluvial system are expected to preserve a larger proportion of floodplain deposits, as predicted in the DFS models, the migration of facies belts due to other controls, such as subsidence rates, may result in the superposition of successions recording alternating bar and channel deposits similar to those of modern perennial channels and sand-rich floodplain deposits showing marked ephemeral flow.

The description of floodplain deposits in pre-vegetation settings presented here has some common points with previous works (Sønderholm and Tirsgaard, 1998; Hadlari et al., 2006; Fralick and Zaniewski, 2012), such as better preserved small-scale sedimentary structures than in post-Devonian deposits, as a consequence of the absence of bioturbation and vegetation-induced baffling. In previous works (Sønderholm and Tirsgaard, 1998; Fralick and Zaniewski, 2012), cross-laminated sandstones are frequent, with minor crossstratified and plane-bedded sandstones and undeformed laminated mudstones, which are also present in FA5 in the present study, which would be the direct result of the absence of bioturbation and vegetation-induced baffling. However, some differences can be noted between the studied example and published ones, especially regarding heterolithic and mudstone facies. In the Santa Bárbara Group mudcracked layers are frequent, as are intraformational mud-clasts in FA5 interpreted as floodplain deposits, while Fralick and Zaniewski (2012) describe the limited occurrence of intraformational clasts in sandstone deposits, Sønderholm and Tirsgaard (1998) and Hadlari et al. (2006) do not describe these features as important in their examples. Loss of sedimentary structure is described by Fralick and Zaniewski (2012) as soft-sediment deformation, as the result of liquefaction combined with fluidization due to rapid sediment deposition. It is distinct, however, in M1 facies, which shows varying degrees of bedding disruption and deformation, locally presenting slickensides and total loss of sedimentary structures, which could be attributed to pedogenesis.

In post-Devonian successions, floodplain deposits can be distinguished based on their much higher mud content, pedogenesis and influence of direct plant colonization. In the case of sand-rich prevegetation floodplain deposits, the distinction between floodplains and real ephemeral fluvial systems may be addressed through the recognition of a lateral transition from channel-belt facies to floodplains, but not directly from vertical profiles. For that reason, even considering the possibility of recognition of humid and semi-humid fluvial styles in pre-vegetation systems, additional care must be taken to interpret climate variation from pre-Silurian fluvial successions.

\section{Conclusions}

The Santa Bárbara Group (Neoproterozoic to Early Cambrian, southern Brazil) comprises sedimentary deposits interpreted as alluvial fans, fluvial channel-belts and fluvial floodplains, which were coeval and migrated both laterally and in the flow direction during basin evolution.

Alluvial fan deposits are restricted to the original basin borders, with conglomerate as the product of water-lain alluvial fans and local debris flow. The channel-belt deposits comprise homogeneous successions of sandstone and pebbly sandstone with some conglomerate levels, which facies and architectural elements are like those of modern braided rivers. The floodplain deposits, with interbedded sandstone and mudstone, are one of the few interpreted cases of pre-vegetation floodplain deposits, and although sharing some characteristics with other pre-vegetation examples, like the sandstone facies and the preservation of small-scale structures, it shows a higher amount of mud-cracked beds, as well as evidence of generation of paleosols.

The coexistence of braided channels and sand-rich floodplains characterizes a depositional environment that has sand-bodies formed in ephemeral floods in the floodplains coeval to sand-bodies formed in the channel-belt under more constant water discharge. Therefore, care must be taken in the interpretation of water discharge regime based on vertical profiles, without the recognition of the lateral transition of alluvial environments. This described scenario contributes to a better understanding of the Late Proterozoic landscapes, proposing a relatively complex relation between different sedimentary environments before the evolution of land plants.

\section{Acknowledgments}

The authors are thankful for the help of Liliane Janikian, Gelson L. Fambrini, Artur J. Cardoso and Ana Paula Pelosi during the fieldwork, to Maurício G. M. Santos, André O. Sawakuchi, and Gregory J. Retallack for their invaluable comments during the development of this paper, and to the Sedimentary Geology Editor, Dr. Jasper Knight, and Neil Davies and an anonymous reviewer for their careful appreciation of the manuscript. The authors also would like to thank Paul Myrow who encouraged the authors to publish this paper. This paper received the support of the Fundação de Amparo a Pesquisa do Estado de São Paulo (FAPESP) in the form of research grant (2009/53362-1) and scholarships for André Marconato (2010/51103-6, 2013/02114-3). We also thank CAPES (PROEX-558/2011) for scholarships for Bruno Turra and André Marconato, and CNPq for scholarship for Renato Almeida (301774/2012-9). This study is a NAP GEO-SEDEX contribution, with the institutional support of the University of São Paulo (PrPesq).

\section{References}

Alexander, J., Fielding C.R, 2006. Coarse-grained floodplain deposits in the seasonal tropics: towards a better facies model. Journal of Sedimentary Research 76, 539-556.

Almeida, R.P., 2001. Evolução tectono-sedimentar da Formação Santa Bárbara na Subbacia Camaquã Ocidental. M.S. Thesis Instituto de Geociências - Universidade de São Paulo, Brazil.

Almeida, R.P., 2005. Tectônica e sedimentação do Ediacarano ao Ordoviciano: exemplos do Supergrupo Camaquã (RS) e do Grupo Caacupé (Paraguai Oriental). Ph.D. Thesis Instituto de Geociências - Universidade de São Paulo, Brazil.

Almeida, R.P., Janikian, L., Fragoso-Cesar, A.R.S., Marconato, A., 2009. Evolution of a rift basin dominated by subaerial deposits: the Guaritas Rift, Early Cambrian, Southern Brazil. Sedimentary Geology 217, 30-51.

Almeida, R.P., Janikian, L., Fragoso-Cesar, A.R.S., Fambrini, G.L., 2010. The Ediacaran to Cambrian rift system of Southeastern South America: tectonic implications. Journal of Geology 118, 145-161.

Almeida, R.P., Santos, M.G.M., Fragoso-Cesar, A.R.S., Janikian, L., Fambrini, G.L. 2012 Recurring extensional and strike-slip tectonics after the Neoproterozoic collisional events in the southern Mantiqueira province. Anais da Academia Brasileira de Ciências 84, 347-376.

Bentham, P.A., Talling, P.J., Burbank, D.W., 1993. Braided stream and flood-plain deposition in a rapidly aggrading basin: the Escanilla Formation, Spanish Pyrenees. In: Best, J.L., Bristow, C.S. (Eds.), Braided Rivers. Geological Society of London Special Publication, 75, pp. 177-194.

Best, J.L., Bridge, J.S., 1992. The morphology and dynamics of low amplitude bedwaves upon upper stage plane beds and the preservation of planar laminae. Sedimentology 39, 737-752

Bhattacharyya, A., Morad, S., 1993. Proterozoic braided ephemeral fluvial deposits: an example from the Dhandraul Sandstone Formation of the Kaimur Group, Son Valley, central India. Sedimentary Geology 84, 101-114.

Bicca, M.M. Chemale Jr. F. Jelinek, A.R., Oliveira, C.H.E, Guadagnin, F, Armstrong, R. 2013. Tectonic evolution and provenance of the Santa Bárbara Group, Camaquã Mines region, Rio Grande do Sul, Brazil. Journal of South American Earth Sciences 48, 173-192.

Blair, T.C., 1999a. Cause of dominance by sheetflood vs. debris-flow processes on two adjoining alluvial fans, Death Valley, California. Sedimentology 46, 1015-1028.

Blair, T.C., 1999b. Sedimentary processes and facies of the waterlaid Anvil Spring Canyon alluvial fan, Death Valley, California. Sedimentology 46, 913-940.

Blair, T.C., 1999c. Sedimentology of the debris-flow-dominated Warm Spring Canyon alluvial fan, Death Valley, California. Sedimentology 46, 941-965. 
Blair, T.C., McPherson, J.G., 1994. Alluvial fans and their natural distinction from rivers based on morphology, hydraulic, sedimentary processes, and facies assemblages. Journal of Sedimentary Research 64, 450-489.

Borba, A.W., Mizusaki, A.M.P., 2003. Santa Bárbara Formation (Caçapava do Sul, southern Brasil): depositional sequences and evolution of an Early Paleozoic postcollisional basin. Journal of South American Earth Sciences 16, 365-380.

Bridge, J.S., 2000. The geometry, flow patterns and sedimentary processes of Devonian rivers and coast, New York and Pennsylvania, USA. In: Friend, P.F., Williams, B.P.J. (Eds.), New Perspectives on the Old Red Sandstone. Geological Society Special Publication, 180 , pp. 85-108.

Bridge, J.S., 2003. Rivers and Floodplains: Forms, Processes and Sedimentary Record. Blackwell Science Ltd, Oxford.

Bridge, J.S., Demicco, R.V., 2008. Earth Surface Processes, Landforms and Sediment Deposits. Cambridge University Press, Cambridge.

Bristow, C.S., Skelly, R.L., Ethridge, F.G., 1999. Crevasse splays from the rapidly aggrading, sand-bed, braided Niobrara River, Nebraska: effect of base-level rise. Sedimentology 46, 1029-1047.

Chemale Jr., F., 2002. Evolução Geológica do Escudo Sul-rio-grandense. In: Holz, M., De Ros, L.F. (Eds.), Geologia do Rio Grande do Sul, CIGO/UFRGS, pp. 13-52.

Corenblit, D., Steiger, J., 2009. Vegetation as a major conductor of geomorphic changes on the Earth surface: toward evolutionary geomorphology. Earth Surface Processes and Landforms 34, 891-896.

Cotter, E., 1978. The evolution of fluvial style, with special reference to the central Appalachian Palaeozoic. In: Miall, A.D. (Ed.), Fluvial Sedimentology. Canadian Society of Petroleum Geologists Memoir, V, pp. 361-384.

Davies, N.S., Gibling, M.R., 2010. Cambrian to Devonian evolution of alluvial systems: the sedimentological impact of the earliest land plants. Earth-Science Reviews 98, $171-200$

Davies, N.S., Gibling, M.R., Rygel, M.C., 2011. Alluvial facies evolution during the Palaeozoic greening of the continents: case studies, conceptual models and modern analogues. Sedimentology 58, 220-258.

Eriksson, P.G., Condie, K.C., Tirsgaard, H., Mueller, W.U., Altermann, W., Miall, A.D., Aspler, L.B., Catuneanu, O., Chiarenzelli, J.R., 1998. Precambrian clastic sedimentation systems. Sedimentary Geology 120, 5-53.

Eriksson, P.G., Bumby, A.J., Brümer, J.J., Neut, M., 2006. Precambrian fluvial deposits: enigmatic palaeohydrological data from the c. 2-1.9 Ga Waterberg Group, South Africa. Sedimentary Geology 190, 25-46.

Fambrini, G.L., 2003. O Grupo Santa Bárbara (Neoproterozóico III) da Bacia do Camaquã, Rio Grande do Sul. Ph.D Thesis Instituto de Geociências - Universidade de São Paulo, Brazil.

Fambrini, G.L., Almeida, R.P., Fragoso-Cesar, A.R.S., 2006. Estratigrafia e evolução paleogeográfica do Grupo Santa Bárbara (Ediacarano) na sub-bacia Camaquã Ocidental, Rio Grande do Sul, Brasil. Revista Brasileira de Geociencias 36, 550-565.

Fielding, C.R., 2006. Upper flow regime sheets, lenses and scour fills: extending the range of architectural elements for fluvial sediment bodies. Sedimentary Geology 190, 227-240

Fielding, C.R., Allen, J.P., Alexander, J., Gibling, M.G., 2009. Facies model for fluvial systems in the seasonal tropics and subtropics. Geology 37, 623-626.

Fordham, A.M., North, C.P., Hartley, A.J., Archer, S.G., Warwick, G.L., 2010. Dominance of lateral over axial sedimentary fill in dryland rift basins. Petroleum Geoscience 16, 299-304.

Fragoso-Cesar, A.R.S., Fambrini, G.L., Almeida, R.P., Pelosi, A.P.M.R., Janikian, L., Riccomini, C. Machado, R., Nogueira, A.C.R. Saes, G.S., 2000. The Camaquã extensional basin: Neoproterozoic to early Cambrian sequences in southernmost Brazil. Revista Brasileira de Geociencias 30, 438-441.

Fralick, P., Zaniewski, K., 2012. Sedimentology of a wet, pre-vegetation floodplain assemblage. Sedimentology 59, 1030-1049

Friend, P.F., Slatert, M.J., Williams, R.W., 1979. Vertical and lateral building of river sandstone bodies, Ebro Basin, Spain. Journal of the Geological Society (London) 136, 39-46.

Fuller, A.O., 1985. A contribution to the conceptual modelling of pre-Devonian fluvial systems. Transactions Geological Society of South Africa 88, 189-194.

Hadlari, T., Rainbird, R.H., Donaldson, J.A., 2006. Alluvial, eolian and lacustrine sedimentology of a Paleoproterozoic half-graben, Baker Lake Basin, Nunavut, Canada. Sedimentary Geology 190, 47-70.

Hartley, A., Weissmann, G., Nichols, G., Warwick, G., 2010. Large distributive fluvial systems: characteristics, distribution, and controls on development. Journal of Sedimentary Research 80, 167-183.

Hirst, J.P.P., Blackstock, C.R., Tyson, S., 1993. Stochastic modelling of fluvial sandstone bodies. In: Flint, S.S., Bryant, I.D. (Eds.), The Geological Modelling of Hydrocarbon Reservoirs and Outcrop Analogues. IAS Special Publication, 15, pp. 237-251.

Hjellbakk, A., 1997. Facies and fluvial architecture of a high energy braided river: the Upper Proterozoic Seglodden Member, Varanger Peninsula, northern Norway. Sedimentary Geology 114, 131-141.
Janikian, L., Almeida, R.P., Trindade, R.I.F., Fragoso-Cesar, A.R.S., D'Agrella-Filho, M.S Dantas, E.L., Tohver, E., 2008. The continental record of Ediacaran volcanosedimentary successions in southern Brazil and their global implications. Terra Nova 20, 259-266.

Janikian, L., Almeida, R.P., Fragoso-Cesar, A.R.S., Martins, V.T.D.S., Dantas, E.L., Tohver, E., McReath, I., D'Agrella-Filho, M.S. 2012. Ages (U-Pb SHRIMP and LA ICPMS) and stratigraphic evolution of the Neoproterozoic volcano-sedimentary successions from the extensional Camaquã Basin, Southern Brazil. Gondwana Research 21, 466-482.

Kolesnikov, A.V., Grazhdankin, D.V., Maslov, A.V., 2012. Arumberia-type structures in the Upper Vendian of the Urals. Doklady Earth Sciences 447, 1233-1239.

Long, D.G.F., 1978. Proterozoic stream deposits: some problems of recognition and interpretation of ancient sandy fluvial systems. In: Miall, A.D. (Ed.), Fluvial Sedimentology. Canadian Society of Petroleum Geologists Memoir, V, pp. 313-342.

Long, D.G.F., 2004. Precambrian rivers. In: Eriksson, P.G., Altermann, W., Nelson, D.R., Mueller, W.U., Catuneanu, O. (Eds.), The Precambrian Earth: Tempos and Events. Elsevier, Amsterdam, pp. 660-663.

Long, D.G.F., 2006. Architecture of pre-vegetation sandy-braided perennial and ephemeral river deposits in the Paleoproterozoic Athabasca Group, northern Saskatchewan, Canada, as indicators of Precambrian fluvial style. Sedimentary Geology 190, 71-95.

Marconato, A., Almeida, R.P., Santos, M.G.M., Nóbrega, J.E.S., Souza, R.B., 2009. Alluvialeolian interaction in a Cambrian rift margin: the Pedra das Torrinhas and Pedra Pintada formations (Guaritas Group, RS). Anais da Academia Brasileira de Ciências 81, 819-836.

Miall, A.D., 1978. Lithofacies types and vertical profile models in braided river deposits: a summary. In: Miall, A.D. (Ed.), Fluvial Sedimentology. Canadian Society of Petroleum Geologists Memoir, V, pp. 313-342.

Murray, A.B., Knaapen, M.A.F., Tal, M., Kirwan, M.L., 2008. Biomorphodynamics: physicalbiological feedbacks that shape landscapes. Water Resources Research 44, W11301. http://dx.doi.org/10.1029/2007WR006410.

Nichols, G.J., Fisher, J.A., 2007. Processes, facies and architecture of fluvial distributary system deposits. Sedimentary Geology 195, 75-90.

Paim, P.S.G., 1994. Depositional Systems and Paleogeographical Evolution of the Camaquã and Santa Bárbara Basins, Brazil. Ph.D. Thesis University of Oxford, UK.

Paim, P.S.G., Lopes, R.C., Chemale Jr., F., 1995. Aloestratigrafia, sistemas deposicionais e evolução paleogeográfica da Bacia do Camaquã - Vendiano Superior Ordoviciano Inferior do RS. VI Simpósio Sul-Brasileiro de Geologia. I Encontro Geologia do Cone Sul, pp. 39-50.

Rainbird, R.H., 1992. Anatomy of a large-scale braid-plain quartzarenite from the Neoproterozoic Shaler Group, Victoria Island, Northwest Territories, Canada. Canadian Journal of Earth Sciences 29, 2537-2550.

Ramaekers, P., Catuneanu, O., 2004. Development and sequences of the Athabasca Basin, Early Proterozoic, Saskatchewan and Alberta, Canada. In: Eriksson, P.G. Altermann, W., Nelson, D.R., Mueller, W.U., Catuneanu, O. (Eds.), The Precambrian Earth: Tempos and Events. Elsevier, Amsterdam, pp. 705-723.

Retallack, G.J., 1992. How to find a Precambrian paleosol. In: Schidlowski, M., Golubic, S., Kimberley, M.M., McKirdy, D.M., Trudinger, P.A. (Eds.), Early Organic Evolution and Mineral and Energy Resources. Springer-Verlag, Berlin, pp. 16-30.

Retallack, G.J., 2001. Soils of the Past: An Introduction to Paleopedology. Blackwell Science Ltd., Oxford.

Retallack, G.J., 2012. Were Ediacaran siliciclastics of South Australia coastal or deep marine? Sedimentology 59, 1208-1236.

Retallack, G.J., 2013. Ediacaran Gaskiers glaciation of Newfoundland reconsidered. Journal of the Geological Society (London) 170, 19-36.

Santos, M.G.M., Almeida, R.P., Mountney, N.P., Fragoso-Cesar, A.R.S., 2012. Seismites as a tool in the palaeoenvironmental reconstruction of fluvial deposits: the Cambrian Guarda Velha Formation, southern Brazil. Sedimentary Geology 277, 52-60.

Schumm, S.A., 1968. Speculations concerning the palaeo-hydraulic controls of terrestrial sedimentation. Geological Society of America Bulletin 79, 1573-1588.

Shultz, A.W., 1984. Subaerial debris-flow deposition in the Upper Paleozoic Cutler Formation, Western Colorado. Journal of Sedimentary Petrology 54, 759-772.

Sønderholm, M., Tirsgaard, H., 1998. Proterozoic fluvial styles: response to changes in accommodation space (Rivieradal sandstones, eastern North Greenland). Sedimentary Geology 120, 257-274.

Weissmann, G., Hartley, A., Nichols, G., Scuderi, L., Olson, M., Buehler, H., Banteah, R., 2010. Fluvial form in modern continental sedimentary basins: distributive fluvial systems. Geology 38, 39-42.

Winston, D., 1978. Fluvial systems of the Precambrian Belt Supergroup, Montana and Idaho. In: Miall, A.D. (Ed.), Fluvial Sedimentology. Canadian Society of Petroleum Geologists Memoir, V, pp. 343-359.

Wolman, M., Brush, L., 1961. Factors controlling the size and shape of stream channels in coarse non-cohesive sands. Physiographic and Hydraulic Studies on Rivers, 1956-1961. USGS Professional Paper 282-G, pp. 183-210. 


\title{
6. Floodplain record in the Early Cambrian Varzinha Formation (Southern Brazil): channelized and unconfined flow in the absence of vegetation
}

\author{
Marconato, A., Almeida, R.P., Janikian, L., Carrera, S.C., Turra, \\ B.B., Santos, M.G.M., Gallas, J.D.F.; Stern, A.G.
}

\begin{abstract}
Floodplains are areas of unconfined and episodic water flow that have been extensively affected by the first appearance and subsequent evolution of land plants. In this respect, the scarcity of documented examples of pre-Silurian floodplain deposits contrasts with the growing interest in the recognition of the variability of fluvial channel deposits of the same age. The study of the deposits of floodplains and coeval channels in successions older than the Silurian enables the comparison of the processes acting on channelized and unconfined settings before the colonization of the latter by land plants caused the differentiation between hydraulic parameters in those settings. The object of this study is the Varzinha Formation (Guaritas Group, Cambrian of the Southern Brazil), which bears sandy and heterolithic beds that occur in the same stratigraphic level, and are coeval with basin-border conglomerates. The record of the Varzinha Formation is interpreted as an alluvial valley cut by a braided channel system, that left channelized deposits mainly close to the eastern border. The channels were bordered by broad areas of sand deposition, mostly during unconfined overbank flow, which formed levee deposits similar to those from modern settings, except for a higher width to thickness ratio, possibly due to less bank stabilization. These deposits show scour fills interpreted to run downstream to the floodbasin as ribbon channels. Since the channel belts did not show strong avulsion rates, due the combination of aggradational infilling of the basin and perhaps a buffer effect of the wider levee system, fine grained floodbasin deposits were deposited and preserved in the distal reaches of the alluvial plain. The existence of paleosols suggests that flat surfaces were locally long lived, and that the rate o deposition in the floodbasin would not be high, as expected for a this environment. This features are indicative of a fluvial system that had a well drained floodplain, and channel system that may not have been subjected to extreme variation of flow discharge, resulting in the construction of alluvial ridges. A particular feature of these deposits are Froude Transcritical and Supercritical Structures, formed during bank-full flow over bars in the fluvial channel belt and in regions of local high slope in the floodplain, related to the flow
\end{abstract}


from alluvial ridges down the levee deposits and distal reaches of alluvial fans, fed from the eastern basin border. The record of coarse grained floodplain deposits in pre-vegetation settings brings new elements to the identification of floodplain deposits in the Precambrian and Early Paleozoic, being in agreement with the recent recognition of the greater variety of alluvial environments deposited prior to the evolution of vascular plants.

\section{Introduction}

Floodplains are areas of unconfined and episodic water flow that, given the generalized availability of water, nutrients and stable substrate have been extensively affected by the first appearance and subsequent evolution of land plants. In this respect, the scarcity of documented examples of pre-Silurian floodplain deposits (e.g., Sønderholm \& Tirsgaard, 1998; Hadlari et al., 2006; Fralick \& Zaniewski, 2012) contrasts with the continuous and decades-long debate on the effects of land plants evolution on fluvial channel-styles (Long, 1978, 2004, 2011; Schumm, 1981; Davies \& Gibling, 2010; Davies \& Gibling, 2011; Davies et al., 2011; Gibling \& Davies, 2012). Given the importance of floodplains as sites of sediment storage, silicate minerals weathering and development of soil profiles, this lack of data on ancient floodplains has great implications for our understanding of the source-to-sink systems, the climate record and the global geochemical cycles of the Precambrian and the Early Paleozoic (e.g., Kennedy et al., 2006).

Even in post-Silurian successions, the interpretation of the products of unconfined overland flow, which prevail on floodplains, is subject to misconceptions and generalized use of poorly defined terms, regarding both processes and particular environments (see North \& Davidson (2012) for a comprehensive review). Additionally, interpreted discharge variation within channel deposits, based on the same criteria traditionally applied to define episodic flow in unconfined setting, has recently been proposed as a tool to recognize past climate change (e.g., Fielding et al., 2011; Allen et al., 2013).

In this respect, the study of the deposits of floodplains and coeval channels in successions older than the Silurian enables the comparison of the processes acting on channelized and unconfined settings before the colonization of the latter by land plants caused the differentiation between hydraulic parameters in those settings.

The present work is based on detailed descriptions of deposits of channels and floodplains from selected outcrops of the Cambrian Varzinha Formation (Southern Brazil), aiming to document the facies associations of pre-vegetation floodplain environments. 
Additionally, the work aims to investigate the spatial distribution of Froude Transcritical and Supercritical Structures (FTSS) and their depositional processes and depositional settings, in order to test hypothesis that ascribe variations in discharge (flow power) as the main control in their preservation.

\subsection{Sedimentary structures and discharge variation}

Supercritical (upper-stage) bedforms and related sedimentary structures have been associated to unconfined or poorly confined flow of episodic or ephemeral nature by several authors (e.g., Miall, 1985; Tooth, 2000, 2005; Fielding, 2006; Fielding et al., 2009; North \& Davidson, 2012), but the rationale for this interpretation are not clearly stated. Instead, a relationship between the shallow depths implied in unconfined flow and high Froude numbers is generally considered, with no mention of the slope gradient, the discharge and the cross-section geometry of the flow. The same is true for the interpretation of Froude Transcritical and Supercritical Structures (sensu Fielding et al., 2011), for which the rapid variation of flow strength necessary for their preservation is emphasized (e.g., Fielding et al., 2009; Fielding et al., 2011; Allen et al., 2011), but the particular conditions for the establishment of supercritical flow (e.g., critical depth, critical slope) are not considered. In this way, the generalized common assumption of direct relation between high Froude numbers and ephemeral or intermittent flow seems to be implied.

Since supercritical and subcritical flow are two possible regimes for the same discharge of flowing water, other parameters must be considered to determine which situation is found in a particular channel or unconfined flow. An useful approach is to apply empirical equations of open-channel flow, such as the Chezy-Manning equation (1), which relates discharge to slope and cross-section geometry of the flow, given a parameter accounting for the texture of the substrate (Manning number). With both the Froude (2) and the Chezy-Manning equations, it is possible to determine in which conditions a particular channel develops subcritical and supercritical flow. This simple approach, widely applied in hydraulic engineering, contradicts some common assumptions regarding processes and products of both ephemeral and unconfined flow:

(I) For the same longitudinal slope and discharge, narrower channels show higher Froude numbers than wider channels, and therefore supercritical flow is not particularly favored in unconfined settings. This happens because the velocity is greatly decreased with 
the increase of the wetted perimeter in relation to the cross-section area of the flow.

(II) For constant longitudinal slope and channel form, increased discharge implies higher Froude numbers, and therefore supercritical flow is more likely to occur during episodes of deeper water flow.

(III) In flows composed of a deeper and narrower main channel and shallower and wider areas of connected flow, Froude numbers are much greater in the deepest channel.

Therefore, in a given setting where the main channel, or the equivalent unconfined flow is able to episodically reach supercritical conditions, supercritical bedforms and sedimentary structures will form preferentially during peak discharge and in the deepest areas of the flow (but see below). The colonization of areas of shallow intermittent flow by vegetation tend to amplify these effects, increasing the Manning number in those areas.

In addition to the discharge, longitudinal slope gradient is a major control in determining the Froude number (Fr) of a given channel, and the concept of critical slope (causing $\mathrm{Fr}=1$ ) is of common use in hydraulic engineering. This variable is only indirectly related to discharge variation, since ephemeral and intermittent rivers tend, mostly due to the reduced mean discharge, to show lower transport efficiency than perennial rivers, and therefore are expected to show steeper graded profiles (see Paola et al. (1992) for a numerical approach).

The direct control exerted by local longitudinal slope on the Froude number brings additional uncertainties in the tentative interpretation of discharge variation based on the proportion of preserved FTSS (e.g., Allen et al., 2013). The interpretation of the record of relative discharge variation in channel-fill deposits from different stratigraphic levels in a sedimentary basin must consider that slopes progressively decrease downstream, and therefore the same channel can preserve a greater proportion of FTSS in proximal than in distal settings. Additionally, the slow adjustment of the longitudinal profile of the river to changes in external controls (e.g., Paola et al., 1992; Paola, 2000) implies temporal variations in the river slope at any given position in the basin. In this way, changes in the proportion of FTSS can be the result of changes in slope caused by factors that are independent from the discharge regime.

Another important observation is that local environments in a channel-belt can easily develop supercritical flow even where Froude numbers are very low at peak discharge in the thalweg of the main channel. Two particularly common situations are quasi or supercritical flow (interpreted from plane-bedded fine sand) in bar tops (e.g., Bristow, 1993) and in 
crevasse splays, levees and proximal floodplains (e.g., Fielding, 1986; Bridge, 2003; Mjøs et al., 2009). In the first case, high Froude numbers are attained when the rapid near-surface waters of the subcritical flow in the main channel find an obstacle (the bar head) and have their depth greatly reduced before the bottom shear is able to proportionally reduce the flow velocity. In this situation, a range of different controls on the formation and preservation of bar-top successions influence the proportion of preserved FTSS in the unit (Freitas et al., 2012). In the second case, the local slope gradient of the flow is much greater and to a different direction than that of the main channel.

Given these theoretical considerations, the present works aims at the detailed interpretation of depositional processes and local settings of different architectural elements bearing FTSS in selected exposures of the Varzinha Formation (Early Cambrian, Southern Brazil), in order to reveal their natural variability and propose specific interpretations avoiding oversimplification and generalization. The particular situation of absence of plant colonization of floodplains favors both the recognition of subtle preserved structures, which could be obliterated by bioturbation, and the comparison between channel-fills and unconfined settings in a context where similar bed roughness can be assumed.

\subsection{Geological Setting}

The Varzinha Formation is part of the Guaritas Group (sensu Almeida et al., 2009), which is the uppermost sedimentary unit of the Camaquã Supergroup (Fragoso-Cesar et al., 2000). The Camaquã Basin (Fig. 01) overlies Paleo- and Neoproterozoic rocks that were part of the Neoprotorezoic orogenic events of Eastern Gondwana, and is part of a system of extensional continental basins that extended from Uruguay to Southeastern Brazil (Almeida et al., 2010, 2012). The continental unmetamorphosed sedimentary and volcano-sedimentary successions of the Camaquã Basin are divided from base to top in the Maricá Group (siliciclastic successions), the Bom Jardim Group (volcanic and volcano-sedimentary successions), the Acampamento Velho Formation (volcanic), the Santa Bárbara Group (siliciclastic successions), and the Guaritas Group (siliciclastic succession), totaling more than $10 \mathrm{~km}$ of Ediacaran sedimentary and volcanic successions (Janikian et al., 2008), deposited and segmented in cycles of extension and strike-slip deformation (Almeida et al., 2010, 2012). The entire history of the basin spans a period between ca. $590 \mathrm{Ma}$ and $535 \mathrm{Ma}$, from the end of the Neoproterozoic to the early Cambrian (Chemale Jr., 2002; Hartmann et al., 2008; Janikian et al., 2008; Almeida et al., 2010; Janikian et al., 2012; Oliveira et al., 2014). 


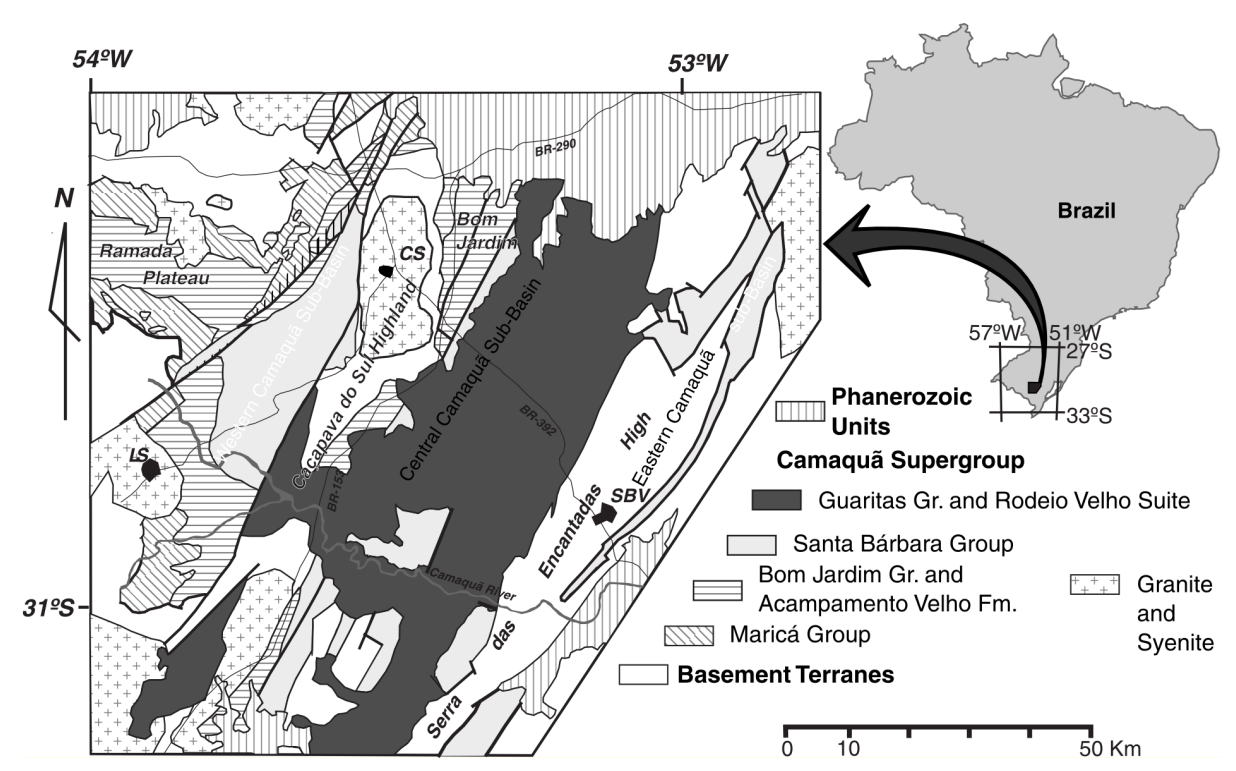

Fig. 01: Geological sketch map of the Camaquã Basin and surrounding basement, showing the distribution of its main stratigraphic units. Localities: CS - Caçapava do Sul; LS - Lavras do Sul; SBV - Santana da boa Vista. Modified after Fragoso-Cesar et al. (2000) and Almeida et al. (2010).

The Guaritas Group comprises a more than $1500 \mathrm{~m}$ thick succession of pebbly sandstones, conglomerates, sand-mud rhythmites and fine- to medium-grained sandstones with large-scale cross-bedding. The sandstones are mineralogically immature, varying from arkoses to lithic arkoses depending on the local provenance (De Ros et al., 1994; Nóbrega et al., 2008). Following the stratigraphy proposed by (Almeida et al., 2009), the group is divided into five main units (Fig. 2), which were deposited in continental environments. The positioning of the Guaritas Group in the Cambrian is supported by direct age determination of the Rodeio Velho Intrusive Suite, with 535.2+/-1.1 Ma obtained from basic intrusions in unconsolidated sediments of the Varzinha Formation, and by detrital zircon age determinations, which show an youngest age coincidently at 535+/-10 Ma (Hartmann et al., 2008). Age determination of illite authigenesis in the Guaritas Basin in the interval between 520 470 Ma (Maraschin et al., 2010) is compatible to the positioning of the Guaritas Group in the Cambrian, as the method records mesodiagenetic processes that would have taken place after the sedimentation and considerable burying.

The eolian successions, grouped in the Pedra Pintada Formation have drawn much interest of sedimentological studies in the basin (Paim, 1996; Scherer et al., 2003; Paim \& Scherer, 2007; Marconato et al., 2009), but there is a growing interest in the sedimentological aspects of fluvial successions, including the Guarda Velha Formation (Paim, 1994; Santos et al., 2012, 2014) and the Serra do Apertado Formation (Almeida, 2005; Godinho et al., 2013b), and to a minor extent the eastern border alluvial-fan deposits of the Pedra das Torrinhas 


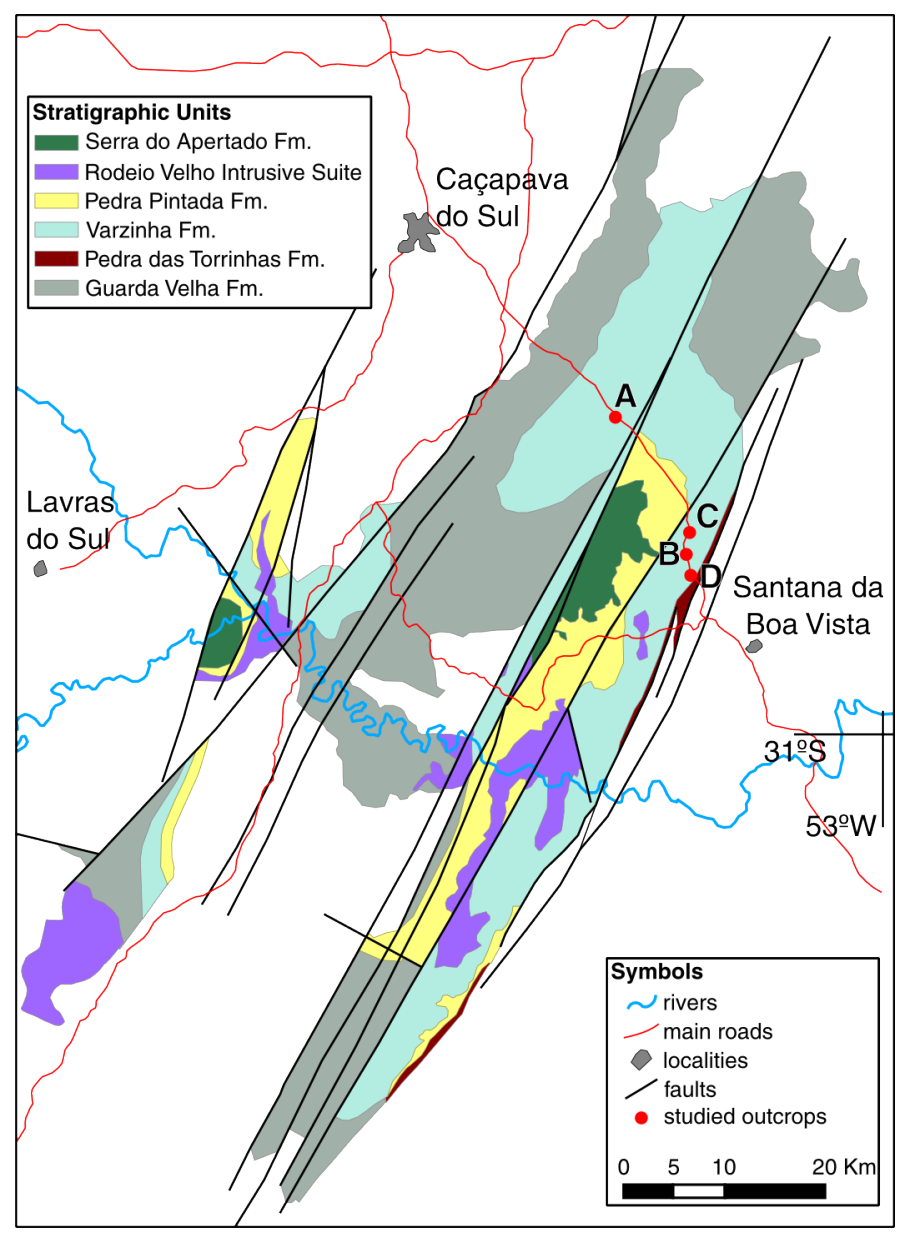

Fig. 02: Geological sketch map detailing the area of the Guaritas Group as depicted in Fig. 01 and including its composing units. Points A, B, C, and D correspond respectively to the outcrops described in the figures 04, 06, 08, and 09. Map modified from Almeida et al. (2010).

Formation and their relation to inter-fingering deposits (Marconato et al., 2009; Godinho et al., 2013a, 2013b). Considerations regarding paleoclimate are scarce, mostly relying in the sedimentological characteristics of the deposits, such as the presence of dune fields and interpretation of short lived ephemeral rivers (Paim, 1994; Paim \& Scherer, 2007; Godinho et al., 2013b), or in the mineralogical maturity of sandstone (De Ros et al., 1994) or from heavy minerals composition (Nóbrega et al., 2008), in order to propose an arid or semi-arid climate setting during the deposition of the Guaritas Group.

\section{Facies associations}

The Varzinha Formation comprises a variety of sandstone and mudstone deposits (see Table 1 for description and interpretation of facies), with distinct facies associations that can be related to different sedimentary environments. The following descriptions are 
Table 1: Description and interpretation of sedimentary facies.

\begin{tabular}{|c|c|c|c|}
\hline code & facies & description & interpretation \\
\hline S1 & $\begin{array}{l}\text { Trough } \\
\text { cross-stratified } \\
\text { sandstone }\end{array}$ & $\begin{array}{l}\text { Medium to coarse grained sandstone in } 10 \text { to } 30 \text { centimeter thick sets, with trough } \\
\text { cross-stratification. Intraclasts, sparse granules and small pebbles are a common } \\
\text { feature. }\end{array}$ & $\begin{array}{l}\text { Migration of subaqueous dunes with sinuous crests under } \\
\text { lower-stage flow. }\end{array}$ \\
\hline S2 & $\begin{array}{l}\text { Tabular } \\
\text { cross-stratified } \\
\text { sandstone }\end{array}$ & $\begin{array}{l}\text { Medium grained sandstone, with tabular cross-stratification, slightly tangential at the } \\
\text { base. Sparse intraclasts and granules are less common in comparison to trough } \\
\text { cross-stratified sandstone. }\end{array}$ & $\begin{array}{l}\text { Migration of subaqueous dunes with nearly straight crests under } \\
\text { lower-stage flow. }\end{array}$ \\
\hline S3 & $\begin{array}{l}\text { Low-angle } \\
\text { cross-stratified } \\
\text { sandstone }\end{array}$ & $\begin{array}{l}\text { Medium to coarse grained sandstone, rarely with sparse granules, with low-angle } \\
\text { cross-lamination. }\end{array}$ & $\begin{array}{l}\text { Migration of low-amplitude bedforms under currents near the } \\
\text { transition between lower- and upper-stage flows (Fielding, 2006). }\end{array}$ \\
\hline S4 & $\begin{array}{l}\text { Planar stratified } \\
\text { sandstone }\end{array}$ & $\begin{array}{l}\text { Fine to medium grained sandstones, often micaceous, but with no granules. Bedding is } \\
\text { characterized by even, parallel surfaces, and parting lineation can be found on bedding } \\
\text { planes. }\end{array}$ & $\begin{array}{l}\text { Migration of low-amplitude bedforms (bedload sheets sensu } \\
\text { Bridge 2003) in upper-stage flows (Best \& Bridge, 1992). }\end{array}$ \\
\hline S5 & $\begin{array}{l}\text { Sandstone with } \\
\text { sigmoidal } \\
\text { cross-stratification }\end{array}$ & $\begin{array}{l}\text { Isolated sets, } 10 \text { to } 60 \mathrm{~cm} \text { in thickness, of tabular to slightly trough cross bedded } \\
\text { medium (to coarse?) with tangential upper terminations transitioning to low angle and } \\
\text { plane-bedded sandstone }\end{array}$ & $\begin{array}{l}\text { Deposition during progressive change from lower-stage to } \\
\text { upper-stage flow, marked by initial migration of dunes that are } \\
\text { progressively modified and have their shallow parts reworked by } \\
\text { plane-beds and low amplitude bedforms. }\end{array}$ \\
\hline S6 & $\begin{array}{l}\text { Sandstone with } \\
\text { climbing-ripples }\end{array}$ & $\begin{array}{l}\text { Fine to medium grained sandstones, often micaceous, with critical to supercritical } \\
\text { asymmetric climbing ripples. }\end{array}$ & $\begin{array}{l}\text { Migration of ripples due to unidirectional flow with high rate of } \\
\text { deposition from suspension. }\end{array}$ \\
\hline S7 & $\begin{array}{l}\text { Sandstone with } \\
\text { ripple marks }\end{array}$ & $\begin{array}{l}\text { Thin layers of fine grained sandstone with preserved asymmetrical, sinuous-crested, } \\
\text { laterally discontinuous, small-scale bedforms (ripples), often on top of sandstone } \\
\text { deposits, covered by thin mud drapes. }\end{array}$ & $\begin{array}{l}\text { Preservation of bedform (current ripple) due to high rate of } \\
\text { deposition or by cessation of current and eventual covering by } \\
\text { settling deposits. }\end{array}$ \\
\hline S8 & Massive sandstone & $\begin{array}{l}\text { Beds of structureless sandstone with variable thickness, from less than } 5 \mathrm{~cm} \text { up to } 30 \\
\mathrm{~cm}\end{array}$ & Sudden deposition of sand carried in hyper-concentrated flows \\
\hline M1 & Laminated mudstone & $\begin{array}{l}\text { Reddish mudstone deposits with discontinuous lamination. Lamination is often planar, } \\
\text { locally interfingered with centimetric beds of fine sandstone with climbing ripples. }\end{array}$ & $\begin{array}{l}\text { Settling of fine-grained particles in slowly moving or episodically } \\
\text { stagnant water. }\end{array}$ \\
\hline M2 & $\begin{array}{l}\text { Mud-cracked } \\
\text { mudstone }\end{array}$ & $\begin{array}{l}\text { Beds of massive mudstone with mudcracks filled by medium to coarse sand. Bed } \\
\text { thickness ranges from a few millimeters to less than } 10 \mathrm{~cm} \text {, and width of sand ridges } \\
\text { are proportional to the thickness of the dessicated layer. }\end{array}$ & $\begin{array}{l}\text { Subaerial exposure of mudstone deposits, with consequent } \\
\text { dessication of clay minerals and infilling of cracks by airborne } \\
\text { sand. The preservation of the dessicated surface suggests } \\
\text { limited action of erosion. }\end{array}$ \\
\hline M3 & Massive mudstone & $\begin{array}{l}\text { Beds of massive mudstone with variable thickness, ranging from less than } 1 \mathrm{~cm} \text { to more } \\
\text { than } 20 \mathrm{~cm} \text {. }\end{array}$ & $\begin{array}{l}\text { Settling of fine-grained particles in water bodies with negligible } \\
\text { current. }\end{array}$ \\
\hline $\mathrm{P}$ & Paleosols & $\begin{array}{l}\text { Red-colored mudstone with vestigial or no apparent sedimentary structure, seldom with } \\
\text { gleyed mottles. }\end{array}$ & $\begin{array}{l}\text { Incipient formation of soil, with loss of the more delicate } \\
\text { sedimentary features. }\end{array}$ \\
\hline
\end{tabular}



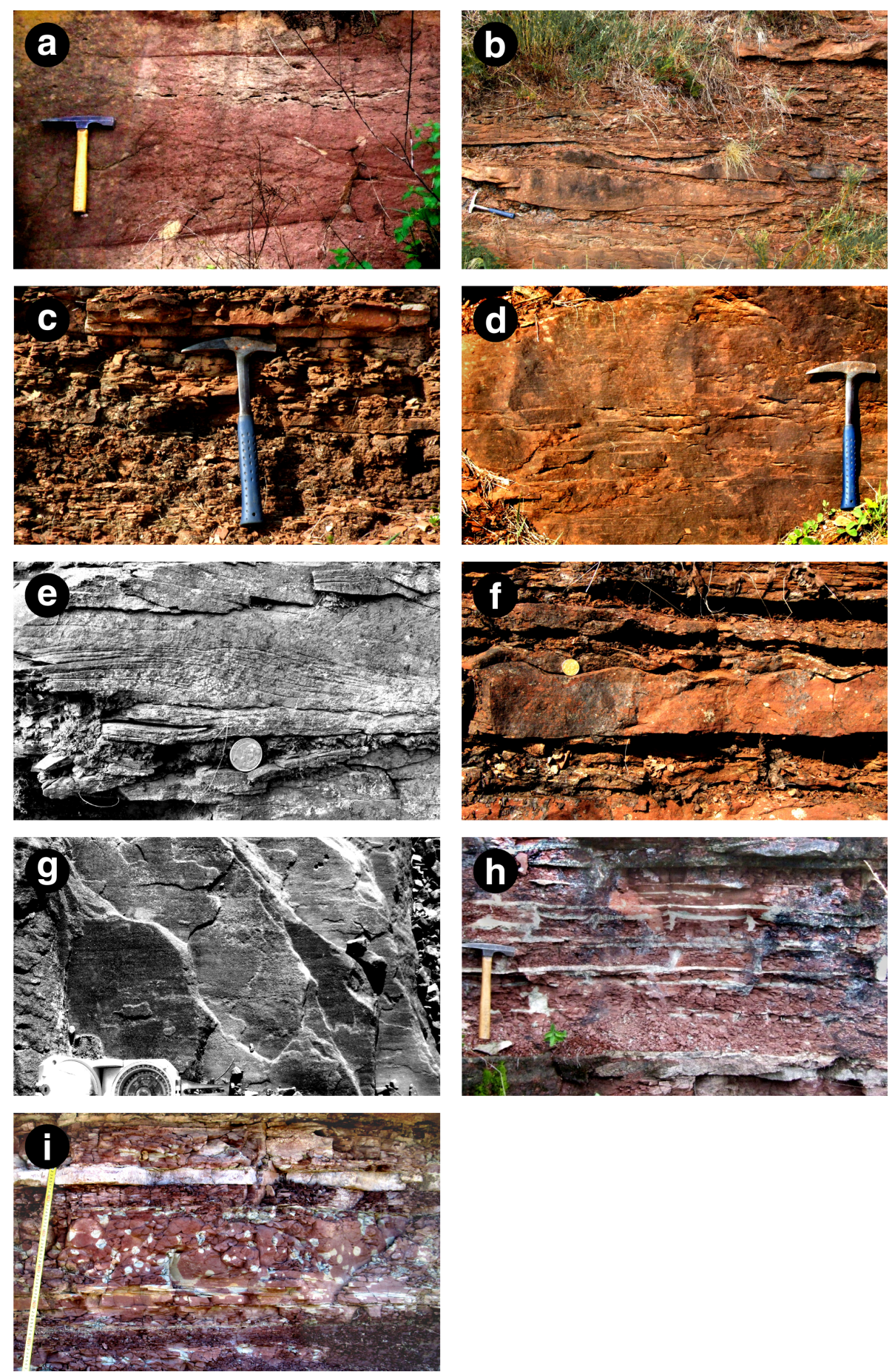

Fig. 03: Examples of sedimentary facies found in the Varzinha Formation (for descriptions see Table 01). a Trough cross-stratified sandstone of S1 facies. Note mud intraclasts in the trough on the upper third of the image; $b$ - Bedform preservation of S1 facies on top of a Channel Form, in the center of the picture. The upper half represents intercalation of sandstone of facies S4 and S6 and mudstone of facies M1 and M2; c Detail of intercalation of S3 and M1 facies; d - Detail of even, planar stratification of facies S4; e Sigmoidal cross-stratification in facies S5; f - Sandstone deposits showing transition from low-angle cross-stratification of facies S3 to rippled sandstone of facies S7 in the same sandstone bed (center of the picture), which is interbedded with thin drapes of facies M1; g - partition lineation in planar stratified S5 facies; $\mathrm{h}$ - Massive mudstone of facies M3 and mudcracked mudstone of facies M2; i - Paleosol of P facies overprinting S3 and M3 facies. There is a progressive obliteration of sedimentary structures from a S3 layer (lower third of picture) to the massive, mottled B horizon that is caped by a more oxidized, platy A horizon (upper third of picture). 
representative of the variety of deposits found in the central and eastern part of the Guaritas Basin, and in spite of the difficulties in maintaining a rigorous stratigraphic control between the studied outcrops, it is reasonable to consider the following descriptions as representative of coeval deposits in the same basin. The studied outcrops are road cuts along the federal road BR-392, between the localities of Caçapava do Sul and Santana da Boa Vista. The exposures are up to seven $\mathrm{m}$ in height, and are hundreds of meters long, which allowed investigation of lateral variation of facies associations. These road cuts expose even the fine grained rocks, which are not usually preserved in natural outcrops, due to recent weathering

\subsection{Inclined cross-bedded cosets and scour fills}

Sandstone deposits with abundant trough cross-sets (S1, Fig. 03A), which are associated with minor tabular cross-sets (S2).The deposits have a tabular organization, in strata that usually ranges from 0.3 to 1.2 meters in thickness, with major surfaces dipping gently downstream (Fig. 04). The internal structure of the strata can be exclusively made of sets of trough cross-stratified sandstone (S2), that in perpendicular to diagonal cuts shows festooned geometry. Additionally, other features can be found, like low-angle cross-stratification (S3, Fig. 03D) and sigmoidal cross-stratification (S5, Fig. 03E), which are often associated, with the low-angle cross-stratification typically changing downstream to sigmoidal cross-stratification.

The coarsest grained facies found in the Varzinha Formation typically comprised medium to coarse grained sandstone with sparse granules and pebbles. These deposits are dominated by $\mathrm{S} 1$ facies and minor S2, with a variable distribution of S3 and S5 facies. Although being common, S1 facies do not appear uniformly in the sandy deposits. In the most common association, S1 facies are part of inclined cosets, where a minor contribution of S2 is present. The sets are 20 to $30 \mathrm{~cm}$ thick on average, separated by downstream dipping set boundaries (see rose diagrams in Fig. 05A). The cosets are in the thickness range of 0.5 to 1.0 $\mathrm{m}$, and are sometimes covered by thin sheets of S4 facies (less than $3 \mathrm{~cm}$ thick), except where bounded by planar, higher order erosive surfaces. Other occurrence of S1 facies is in larger festoons, bounded by lower concave up surfaces that reach thicknesses of $1.0 \mathrm{~m}$ and lengths of 4.0 to $8.0 \mathrm{~m}$. In this case $\mathrm{S} 1$ facies appears as a single set, with its depositional surfaces concordant with the concave up scoured base. These simple scour fills are found mostly on top of inclined cosets, but can be found to erode other facies, and even similar scours. The scouring surfaces can have an oblique direction to the outcrop (see Fig. 04), and the 

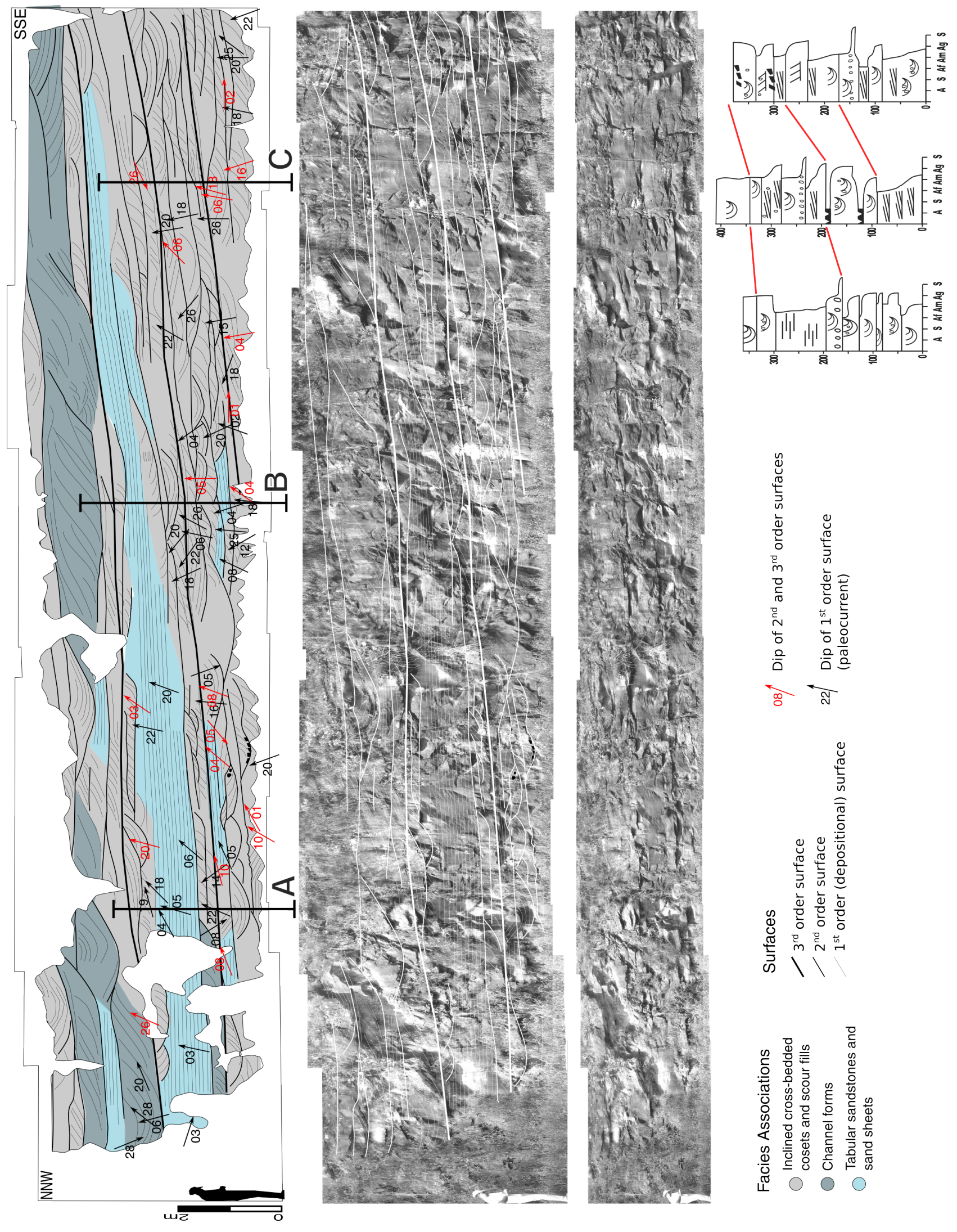

Fig. 04: Photomosaic and architectural interpretation of sandstone deposits formed mainly by Inclined cross-bedded cosets and scour fills and Tabular sandstone and sand sheets, showing interpretation of the outcrop, vertically exaggerated $(2 \mathrm{x})$ mosaic with interpreted surfaces, and mosaic with no vertical exaggeration. Bars A, B, and C, refer to stratigraphic logs. Rose diagrams for paleocurrent and bounding surfaces can be found in Fig. 05 . 


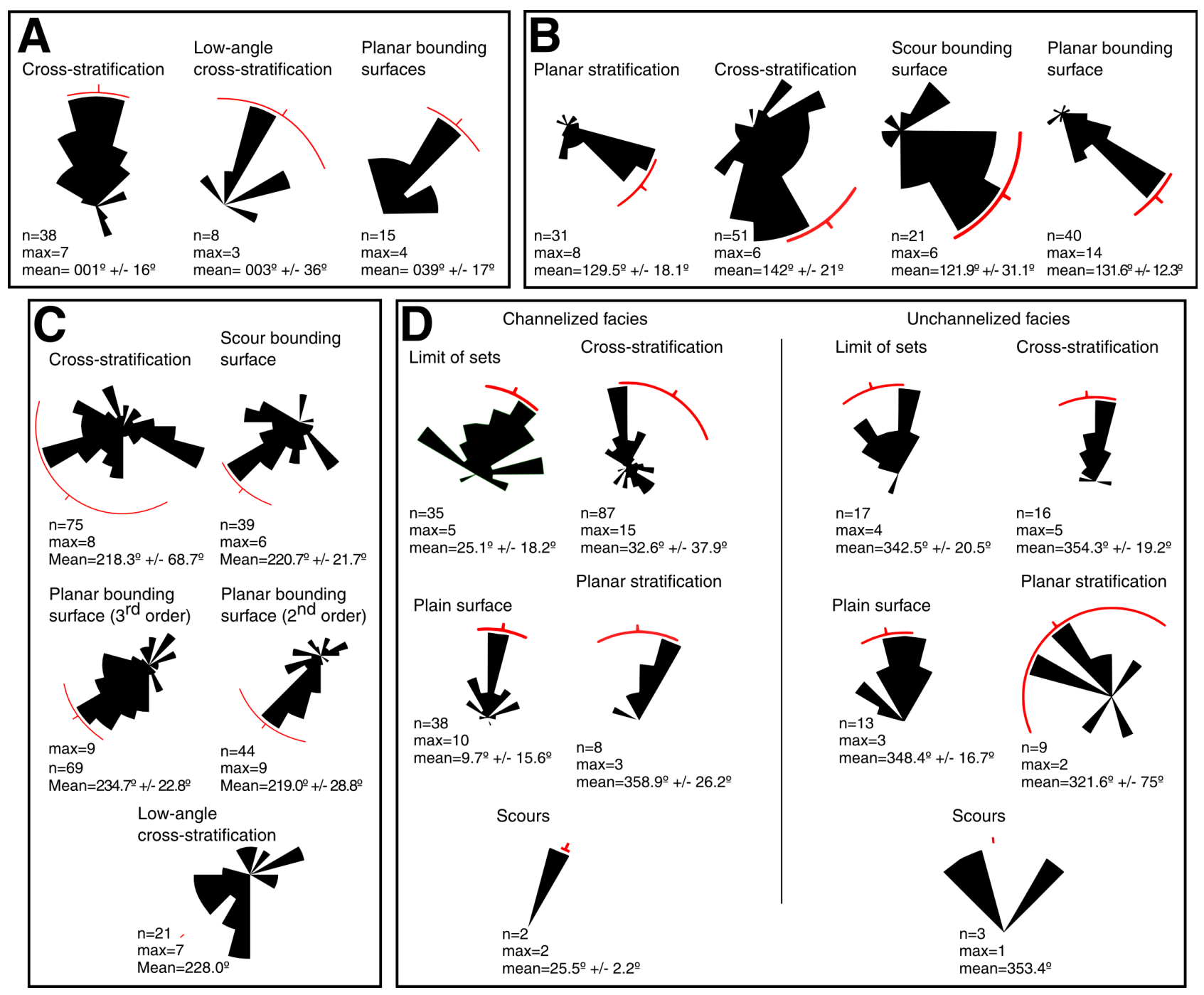

Fig .05: Rose diagrams of palaeocurrents and bounding surfaces for the outcrops detailed in the following figures: A - Fig. 04; B - Fig. 06; C - Fig. 07; D - Fig. 09.

orientation of their wall tends to parallel the average dip of the cross strata of the same succession. The upper parts of the scour fills, when not eroded by other similar scours, are bounded by planar, higher order surfaces. Apart from the S1 deposits, the association of facies $\mathrm{S} 5$ and S3, as lateral transitions from the former to the later, are an important feature in the studied outcrops, being recognized as Froude Transcritical to Supercritical Structures (FTSS). These deposits are found as near $1.0 \mathrm{~m}$ thick individual beds of sigmoidal cross stratified sandstone (S5 facies) that passes laterally to S3, which seems to be thinner, although the determination of the actual thickness may be an issue, as these deposits are often covered by S1 facies with erosional bases. Other FTSS structures are suggested by the lateral transition of scalonated sets of S1 facies to continuous S4 facies (Fig. 04). 
The overall arrangement of the described facies are in the form of continuous planar bounding surfaces, that have a gently downstream dip, which bounds beds with thickness ranging from 0.5 to $2.0 \mathrm{~m}$, and show a tabular geometry parallel to main flow. These higher rank surfaces are often associated with a sudden grain size decrease in thin layers (less than 1 $\mathrm{cm}$ ), sometimes with ripple marks or mudcracked thin mudstone drapes. On the other hand, intraclast deposits are very rare in these successions, and when they can be found, they are either found at the higher order bounding surfaces, or in the deeper parts of the scour fills.

The paleocurrents found in the cross-bedded inclined cosets and their scour fills (Fig. 05A) can have a slight variation (up to $30^{\circ}$ ) in the mean value in comparison to the attitude of the flat bounding surfaces. The flat bounding surfaces have very similar mean values, whether they are 2nd or 3rd order surfaces (Fig. 04, 05A), which are not too different from the paleocurrents of low-angle cross-stratified sandstone.

\subsubsection{Interpretation}

The widespread occurrence of inclined cosets of S1 suggests the formation and migration of compound bedforms, rather than the migration of single subaqueous dunes. This features is suggestive of formation of unit bars (e.g., (Bridge, 2003; Reesink \& Bridge, 2007, $2009,2011)$. Isolated scour fills with similar grain-size to the underlying inclined cosets are interpreted as features of local reworking of bar tops by small channels during low stage flow. Scours that lack intraclasts or any other texture difference in relation to the surrounding facies could be the result of flow variation or flow convergence still during the flooding event, while scours which bear mud intraclasts would represent a later reworking of e bar surface, during falling or low stage flows. These interpretation implies an environment inside the channel-belt, giving a clear context for the observed FTSS.

Considering the theoretical considerations about high Froude number flows in open channels (see above), the occurrence of FTSS in the channel belt must be related to steep longitudinal channel profiles, and the alternation between subcritical and transcritical sedimentary structures may be interpreted as a function of discharge variation, with the latter being favored by large discharge events. The most probable mechanism for the development of the FTSS is the effect of the topography of the bars on flow regime variation. The increase in the Froude numbers could be the result of rapid decrease in the depth of the fast-flowing near-surface waters inside the channel, promoted by the obstacle represented by the head of mid-channel bars in near bankfull conditions. This mechanism is observed in modern environments (e.g., Bristow, 1993) and is in accordance with the theory of open channel flow, 
while the alternative interpretation of FTSS being formed due to reduction in discharge is not.

The facies that were interpreted as indicative of low stage flow in the main channel record sudden decrease in the grain size, and occasional migration of ripples and formation of mud drapes associated with the higher order bounding surfaces, with exposition and even ponding on the bar surfaces. However, as the dimensions of the beds are of the same scale in different sand bodies and outcrops, it reasonable to assume that the sedimentation environment did not suffer major changes between flood events, so that the same fluvial belt would be active for several floods before being abandoned during an avulsion. Some of these planar higher order bounding surfaces (Fig. 04) are interpreted as bar increment surfaces. The slightly oblique dip of the bounding surface in relation to the average paleocurrent suggests local oblique accretion, and the characteristics of the facies association (dominance of sand, no clear upward finning trend, length of inclined coset units only five to ten times the preserved thickness of the cosets) suggest downstream migrating bars.

The dominance of this facies association implies in a fluvial system very similar to a sandy braided river, which although subjected to high variation of flow discharge, would have a discrete channel belt, with downstream migrating bars and multiple channels during low stage. The paleocurrents of the studied deposits are in accordance with previous published data for the same unit and the overall trend of the Guaritas Group (e.g., Paim, 1994; Almeida et al., 2009; Marconato et al., 2009; Godinho et al., 2013b; Santos et al., 2012, 2014).

\subsection{Tabular fine to medium-grained sandstone and sand sheets}

Tabular sandstones and sand sheet deposits have a widespread presence in the record of the Varzinha Formation, responding for the majority of the available sandstone outcrops. Grain size is mainly in the range of fine to medium-grained sandstone, although a limited number of outcrops have coarser grained facies, which are discussed below.

The main feature of these deposits are the occurrence of facies S3 and S4 (Fig. 03D, 03F) in laterally continuous beds (Fig. 06). The deposits are disposed in beds of tabular geometry, with thickness varying between $0.3 \mathrm{~m}$ and more than $1.0 \mathrm{~m}$, with lateral widths surpassing the length of any available outcrop, with very subtle thickness variation. One exception to this common aspect are S3 deposits that dip away from a small Channel Form (section 2.3., below) at steeper angles than in other exposures, resulting in a tapered geometry that thins outwards from the channelized feature. This strongly suggests a wedge-like geometry for these deposits, at least when bordering a Channel Form. 


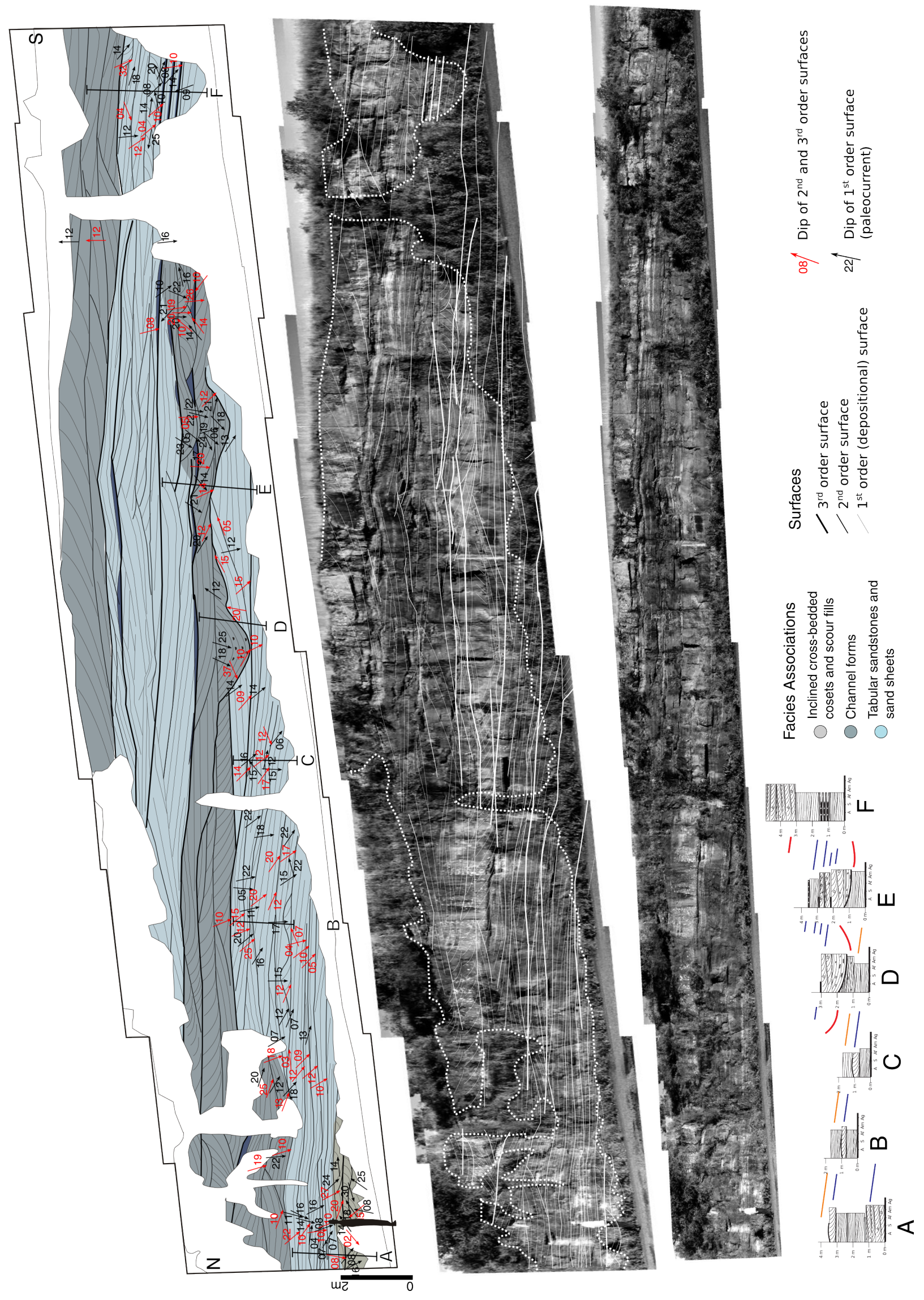

Fig. 06: Photomosaic and architectural interpretation of sandstone deposits rich in Tabular sandstone and sand sheets, with Channel forms, showing interpretation of the outcrop, vertically exaggerated $(2 x)$ mosaic with interpreted surfaces, and mosaic with no vertical exaggeration. Bars A through $F$ refer to stratigraphic logs. Rose diagrams that synthesize the directional data can be found in Fig. 05. 
Although the bulk of the deposits are comprised by S3 and S4 facies (Fig. 03D), other facies can be found, namely thin sheets of S7 on top of S3 and S4 dominated beds, which occasionally have thin claystone drapes covering ripple-marks (Fig.03F), and also discrete scours filled with single cross-stratified sets of facies $\mathrm{S} 1$, with depths ranging from 0.3 to 1.0 $\mathrm{m}$ and widths from 1.5 to $3.0 \mathrm{~m}$ (Fig. 03B).

The bounding surfaces of the Unconfined Flow Sand deposits are generally flat, without pronounced scouring at the base of the deposits, and a upper bounding surface concordant with the bedding planes of S3 and S4 facies. It is not uncommon to find thin sheets (less than $5 \mathrm{~cm}$ ) of M1 or M2 facies on the upper bounding surfaces, often separating two similar successions of tabular sandstones or sand sheets.

The paleocurrent data obtained in in outcrops dominated by Tabular Sandstone and Sand Sheets deposits (Fig. 05B) has very similar mean values across different facies. The cross-bedded S1deposits inside scour fills, as well as the attitude of its concave up boundary are very similar to the paleocurrent data of low-angle cross-stratified sandstone and also to the attitude of the flat boundary surfaces, whether they represent the attitude of 2 nd or 3 rd order surfaces (Fig. 06).

\subsubsection{Interpretation}

The occurrence of relatively thick and extensive deposits of facies S3 and S4 are indicative of supercritical or near critical flow, in settings where shallower waters than those related to the inclined cross-bedded cosets association prevailed. Bed geometries and sedimentary structures are suggestive of unconfined water flow. One way to explain the deposition of flow outside channelized setting regards the increase of the water level inside a given channel or channel belt, to the point that sediment loaded water starts to flow outside the channel. As soon as the water flows away from the channel, the average velocity of the flow may experience a sudden decrease, due to increased shear with the substrate, which would force immediate deposition of the bedload. This mechanism can explain the wedge-shape bed geometry found in part of the unconfined flow deposits, since the rate of deposition close to the channel would be higher than in more distal points of the alluvial plain, resulting in the build-up of alluvial ridges, composed mainly of the fine-sand transported as suspended load during high discharge events. The local increased slope of the flanks of these alluvial ridges may be the origin of the supercritical or near-critical flow, directed towards the floodbasin and therefore not parallel to the main channel belt. 


\subsection{Tabular pebbly sandstones}

Although similar in facies and geometry to the their finer grained counterparts, Tabular pebbly sandstones are composed mainly by coarse grained sandstone deposits of facies S3 and S4, with frequent sparse granules and pebbles. Additionally, these coarser grained deposits locally bear granule lags, generally associated to the top bounding surface of the beds.

It is important to note that these deposits do not have a widespread occurrence across the basin. Instead, their deposits seems to be limited to the vicinities of the eastern border of the basin, not far from the basin-border conglomerates of the Pedra das Torrinhas Formation (Almeida et al., 2009; Marconato et al., 2009).

\subsubsection{Interpretation}

Different processes can be called to explain the formation of unconfined flow deposits, such as local settings in the floodplain close to the channel belt, in which augmented slope gradient (orthogonal to the main channel flow) and episodic overbank flow give rise to poorly channelized flow bearing the suspended sedimentary load of the channel floods. The tabular pebbly sandstone, however, requires another mechanism of formation of unconfined flow deposits. Their position adjacent to basin border alluvial fans suggests unconfined flow in a fan-toe setting (North \& Davidson, 2012), where rapid downstream decrease in gradient is found, resulting in the transition from on-fan channels to areas of unconfined flow. In this situation, the occurrence of supercritical or near-critical flow is controlled mainly by the slope gradient, which is greater than that of the longitudinal slope of the main channels in the same alluvial plain.

Adding to that, the similarity of the inferred paleocurrent obtained in the low-angle cross-stratified facies and in the scour-fill cross-bedded facies favors the interpretation that the slope in this sedimentary setting would be high enough to impact the sedimentary processes, as the direction of the scours were aligned to the paleoflow trend found in facies deposited by different sedimentary processes, such as plain-bedded sandstone and low-angle cross-stratified sandstone. 

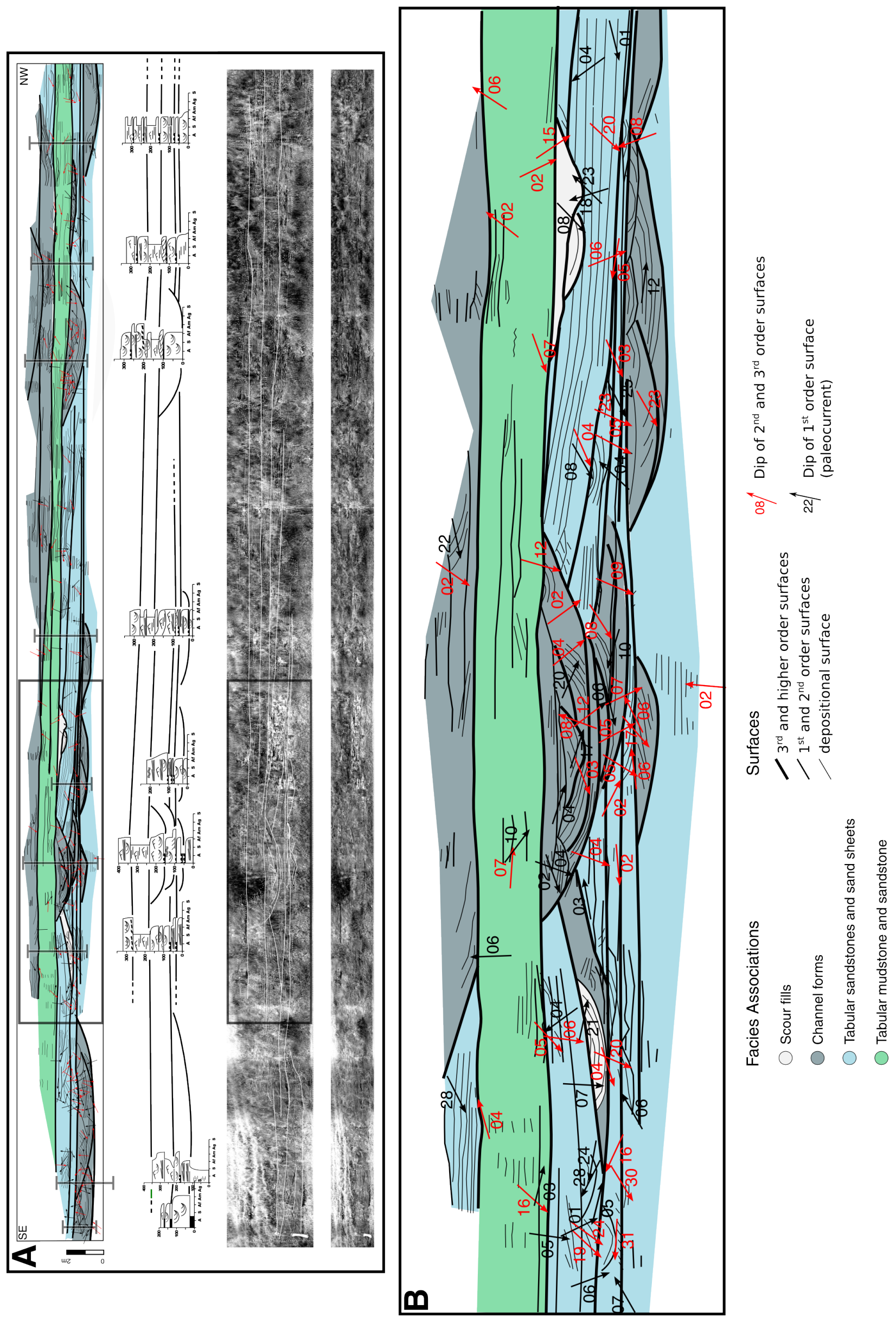

Fig. 07: Subtitles in the bottom of next page 


\subsection{Channel Forms}

The Channel Form deposits are represented by medium to fine-grained sandstones with abundant scour fills of S1 facies. The overall geometry is of concave-up scours, which have depths of about $1.0 \mathrm{~m}$, and lengths ranging from 4.0 to $8.0 \mathrm{~m}$. The filling of the scours is often initiated by a drape of cracked mudstone inside the scour (facies M2, see Fig. 03B), with thickness usually up to $10 \mathrm{~cm}$, which may be followed by a thin bed of S4. The bulk of the scour fill is made by cross-cutting S1 troughs, which, near the top of the infill, transitionally gives place to climbing-ripples of the S6 facies, in some cases topped by preserved bedforms of S7 facies.

The Channel Forms scours are often found among sandstone beds. The most common form of occurrence is as erosive scours cutting Unconfined Flow sandy deposits, and they are often limited on their top by higher order flat surfaces. The mean paleocurrent obtained from the sedimentary facies found inside Channel Forms (Fig. 05C), as well as the orientation of its lower concave-up boundary surfaces, are very similar to the mean values of paleoflow from low-angle cross-stratified sandstone, and also with the attitude of the flat bounding surfaces that top the Channel Forms (Fig. 07).

\subsubsection{Interpretation}

The Channel Forms deposits are initiated by the erosive process that carved the scour form, which would have required an strong locally accelerating flow to take place. The uniform shape of the bigger scours, as well as the mudstone drape in their bottom suggests that most of the geometry were generated in a single erosive event, which latter had settling of mud in ponded water, which eventually dried and resulted in the dessication of the mud drape. The continuation of sediment transport in dune bedforms in subsequent floods resulted in the cross-cutting fill of S1 facies, and as the channel became progressively shallower, the transport capacity of the channel forms were decreased, resulting in the deposition of finer grained sandstone with climbing-ripple cross stratification.

These small Channel Forms may have had an important role in the transport of sediment to more distal areas of the alluvial plain, concentrating flow and transport of

Fig. 07: A - Photomosaic and architectural interpretation for the association of Tabular sandstone, Channel forms and Tabular mudstone and sandstone deposits, showing interpretation of the outcrop, vertically exaggerated $(2 \mathrm{x})$ mosaic with interpreted surfaces, and mosaic with no vertical exaggeration. Bars refer to stratigraphic logs right below. B - Detail of the section that depicts the lateral relation of Channel forms and Tabular Sandstone and sand sheets, which tapers from the channel bodies. Rose diagrams that synthesize the directional data can be found in Fig. 05. 

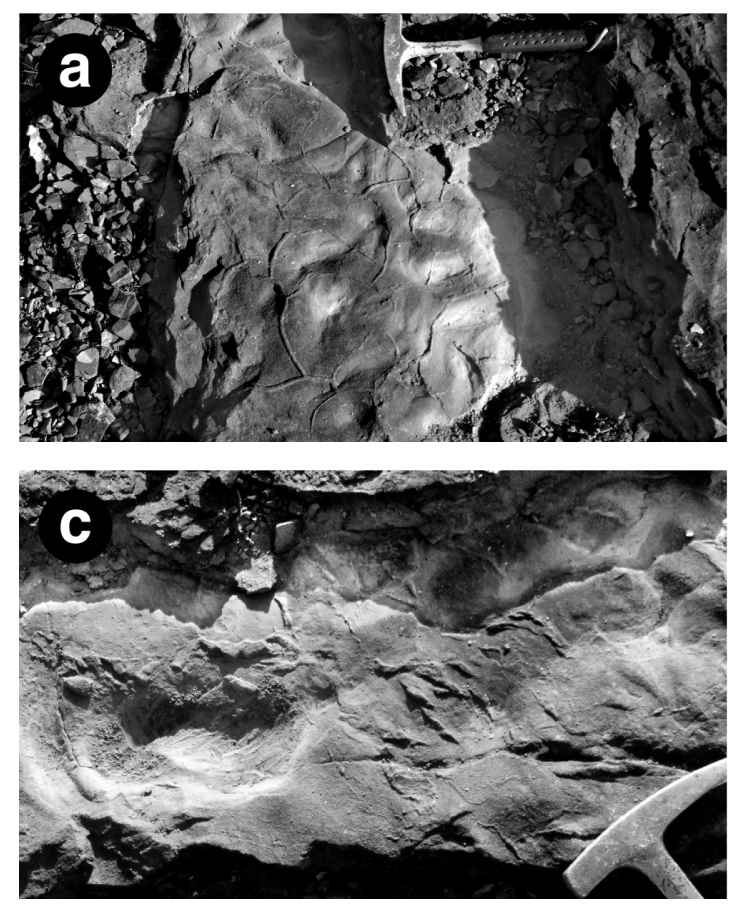

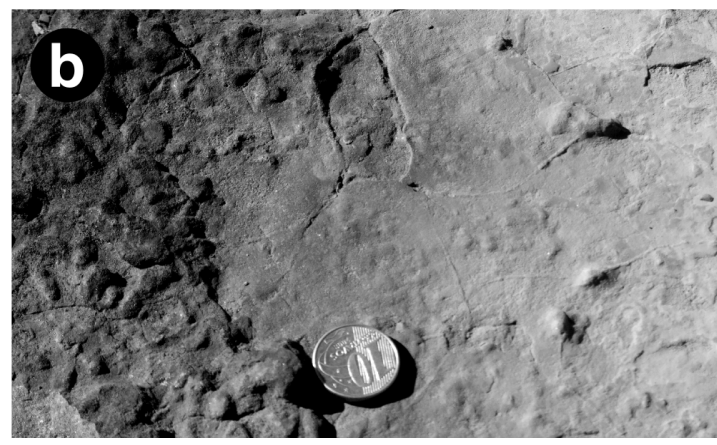

Fig. 08: Features suggestive of algal mats development and decay in fine sandstone on the top of Tabular Sandstone and Sand Sheets deposits. a - Cracked sandstone on top of ripples of facies S7; b - Patchy sandstone mounds, on the left third of the picture, with cracked mudstone with pustules; c - Sand chips, in the center of the picture.

sediment load. The occurrence of the Channel Forms limited to sandy deposits, rather than in muddy or heterolithic deposits, may suggest an association between them, and its is possible that some of the Unconfined Flow sandy deposits were deposited as levees (Fig. 07B), and that this association resulted in the construction of smaller alluvial ridges, which may have occurred at different scales. Thus, the Channel Forms could represent downstream continuation of crevasse channels, forming ribbon channels that would run nearly parallel to the main flow in the floodplain, as indicated by the paleocurrent data (Fig. 05C).

The paleocurrent mean values obtained inside the Channel Form deposits have similar values to the mean paleocurrents found in the plane bedded sandstone which is eroded by its concave-up lower boundary surface. This feature repeats the same relationship found in the Tabular Sandstone and Sand Sheets deposits.

\subsection{Tabular mudstone and sandstone}

Part of the tabular deposits are generally much finner grained than the other deposits in the Varzinha Formation, to the point that any grain size coarser than coarse sandstone is virtually absent. Apart from that, the main feature that characterizes this deposits is the presence of mudstone, whether in laterally extensive mudstone beds, or as drapes separating sandstone bedforms. 
The Unconfined Flow Fine Grained deposits of the Varzinha Formation are comprised mainly by thin beds of thinly stratified very fine sandstone of S6 facies, which often show a transition to M1 layers, in fining upward beds (Fig. 03C). The S6 deposits are set as thin beds, 1 to $5 \mathrm{~cm}$ thick, extending laterally for a few meters. On the other hand, M1 beds are typically thicker, reaching thickness up to $20 \mathrm{~cm}$. The geometry of the beds could not be positively characterized, due both to the high length to thickness ratio, and the overall decayed aspect of the outcrops, which did not allow beds to be followed laterally, except in cases of markedly grain size change or in persistently flat surfaces.

Other features of the these deposits are the occurrence of S7 facies as bedform preservation of trough cross-stratified sandstone, without any transition to finer grained deposits. In fact, fine grained deposits occurs as drapes contouring the top of the bedforms, enabling their preservation. Besides the sandstone layers of S6 and S7, some isolated thin tabular beds of S4 facies can be found, also in thin layers less than $5 \mathrm{~cm}$ thick, and few meters wide.

One common feature of the mudstone deposits is the occurrence of mudcracks, listed as M2 facies, readily identifiable in outcrops as vertical tabular to curved sand fills (Fig. 03H) composing polygonal pattern in plan view, and with widths varying proportionally to the thickness of the containing mudstone beds. The formation of paleosol profiles, grouped in the $\mathrm{P}$ facies, is an important feature of Tabular mudstone and sandstone deposits. Paleosols in weathered outcrops can be distinguished by their stronger red colors in comparison to modern weathering profiles (Retallack, 2001), although the identification of particular structures were often hind by the deterioration of the outcrops. The paleosol profiles grouped in the P facies vary from very poorly developed ones, with partial loss of sedimentary structures in a $\mathrm{C}$ horizon and formation of a platy reddened A horizon, in thin entisol profiles (less than $20 \mathrm{~cm}$ thick), to better developed profiles, up to half meter thick, with a $\mathrm{C}$ horizon showing relict sedimentary structures, a B horizon marked by blocky structure and gleyed spots in massive mudstone, and a platy reddened A horizon, forming inceptisol profiles (Fig. 03I). It is worthy noting that no carbonate nodules were found in those deposits, although carbonate cementation is widespread in the basin (De Ros et al., 1994).

Another particularity of the Tabular mudstone and sandstone deposits is the rare occurrence of indications of microbial mats, such as cracked sand deposits, sand chips, pustules and windows of flat bedding among wrinkled surfaces (Fig. 08), analogous to ripple windows described elsewhere (Schieber, 2004; Eriksson et al., 2007). 


\subsubsection{Interpretation}

The Unconfined Flow Fine Grained deposits have a number of sedimentary facies that suggests deposition in decelerating flows, including the massive sandstone and mudstone facies (facies S8 and M3), as well as the fining upward tractive deposits, with transition from fine sandstone of S6 facies to M1 facies with climbing ripples. This could be the result of pulses of deposition in an already flooded area, which may have caused very fast deposition of the coarser fraction of the sedimentary load (in this case, the fine sand), followed by deposition of progressively finer grained deposits under traction, rather than simply by settling. However, decelerating flows alone cannot explain all the deposits attributes, and the existence of parting lineation in sandstone beds is indicative of deposition of rapid shallow flow in part of the sedimentary environment. Besides the depositional features, post sedimentary modification of the deposits is an important factor in the formation of these deposits. Mudcracks indicate that the flooded areas were short lived, and eventually would dry out and allow for the formation of the cracked features. Additionally, the existence of paleosols is indicative of episodes of sustained periods of non-sedimentation in the area, possibly related to avulsion of the main channel belt. Oxidized paleosols are indicative of a well drained paleosol with some moisture available, which would provide means for mineral transformation in the paleosol profile. It is also important to consider the role of biological activity in this deposits, evidenced by localized traces of microbial mats. Although very scarce and limited, it can be argued that they were probably more widespread in the environment, due to difficulties inherent to their preservation in alluvial environments. Biological activity may have not only enhanced chemical breakage of minerals in the soil profiles, but also probably provided better bidding of sediment particles, thus improving the stability of the sedimentary deposits and inhibiting, or at least decreasing the intensity of erosion in subsequent floods (Noffke, 2000; Schieber, 2004).

\section{Electric tomography data}

Results of electric tomography profiling enabled a better constraining on the architecture of part of the alluvial plain. Taking advantage of an outcrop that had at one extremity fine grained deposits compatible with the description of the floodbasin fines, and at the other end deposits that would fit in the description of the proximal reaches of unconfined flow sandstone and channel belt sandstones, the electric tomography was used in order to assess the relation between these contrasting depositional settings in the shallow subsurface 

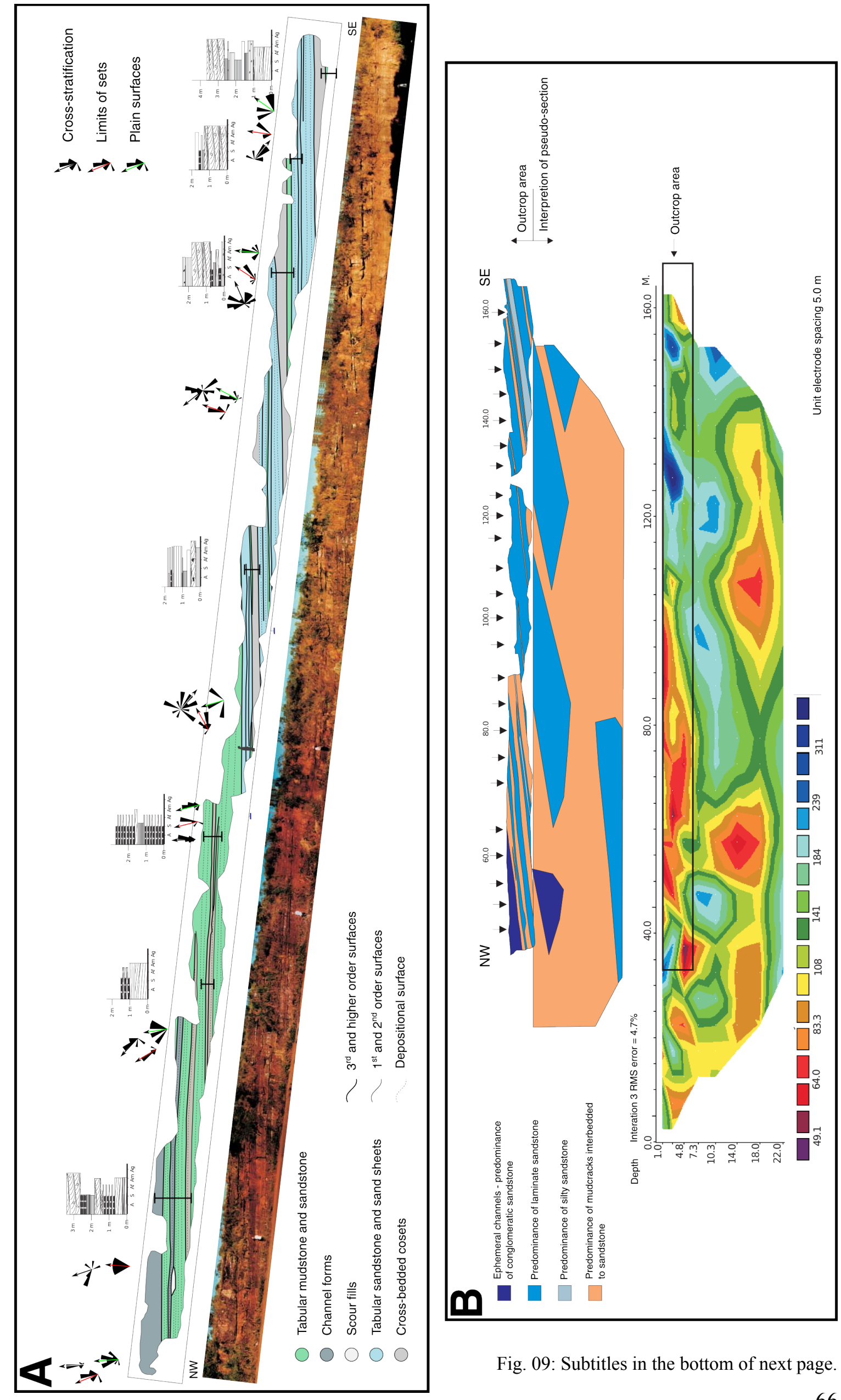

Fig. 09: Subtitles in the bottom of next page. 
(approximately $15 \mathrm{~m}$, Fig. 09). The subsurface extension of the sandstone bodies reveal lenticular geometries, with abrupt termination of the high resistivity bodies surrounded by low resistivity rocks that are in continuation with the outcrops of tabular mudstone deposits, interpreted as representative of a well drained floodbasin. It is worthy to note that the sandstone bodies are not solely build of sandstone facies found in cosets of cross-stratified sandstone, but are also abundant in planar and low-angle cross-stratified sandstone. The succession with more easily attributable to channel belt deposits shows the highest values of resistivity (dark blue colors), and is very restricted in the tomography section. Two stacked sandstone bodies are represented in the section, related to unconfined flow sandstone cropping out at the surface associated with minor cross-bedded cosets, are representative of channel wings running on a floodplain. The fact that the sandstone bodies are stacked so closely suggests an aggradational setting, which would favor the record of floodplain deposits, as described here.

In spite of the bigger sandstone bodies, located in the southern half of the outcrop, in the northern reach of the outcrop there are conglomeratic sandstone deposits identified as deposits of Channel Forms, both in the outcrop and in the false profile. The fact that these smaller Channel Forms are laid directly on floodplain deposits, and are surrounded by thin layers of unconfined flow sandstone, make the interpretation of ribbon channel, like the one shown in Fig. 07B more likely.

\section{Paleoenvironmental reconstruction}

The sedimentary deposits of the Varzinha Formation were described in the previous sections as compartmented parts that can be used as building blocks of an alluvial plain model. The main reason for this are the limited size of the outcrops, so that they may reveal only restricted parts of the basin. The studied outcrops can be ascribed to a channel belt system (Fig. 04), the associated levee and crevasse splay deposits (Fig. 06), and the distal reaches of splay deposits and fine grained floodbasin facies (Fig. 07).

Contrasting features among these deposits of distinct environments include the higher content of laminated sandstone in the outcrop of Fig. 06 in comparison to the example of Fig.

Fig. 09: A - Photomosaic and architectural interpretation of sandstone deposits (southern half of the outcrop), covered by mudstone and fine sandstone deposits (northern half of the outcrop); B Electric tomography profile of the same outcrop, enabling the extrapolation of the geometry of sandstone bodies and the extension of the mudstone and fine sandstone deposits to the nearsubsurface. Rose diagrams that synthesize the directional data can be found in Fig. 05D. 
04, and the higher amount of finer grained deposits of Fig. 07 in comparisson to the other two outcrops. Yet, these examples share some features that suggest intercalation of different alluvial environments and processes, and by extent, original distances between environments in the depositional system.

In this way, the existence of sedimentary facies compatible with in channel deposition on the upper part of the outcrop of Fig. 06 evidences a close relationship of this deposits to the same environment described for the outcrop of Fig. 04, while the occurrence of sandy unconfined flow facies interbedded to tabular mudstone deposits implies some relation between both.

Therefore, the overall aspect of the depositional environment during the deposition of the Varzinha Formation would be that of an alluvial valley cut by channels with braided bars. The channels composed a drainage system that ran northward, being roughly axial to the sedimentary basin (considering the current exposures of the Guaritas Group). These channels were wider or more abundant closer to western border, as suggested by the higher frequency of sandstone outcrops, but they can be found scattered even in more central parts of the basin. The channels were bordered by broad fields of sandstone deposited mostly during unconfined overbank flow, except for the cases were local convergence of flow created scouring, which could progress downstream to the floodbasin as ribbon channels. These broad unconfined flow sandstone bodies would be equivalent to channel levees found in modern settings, except for a higher width to thickness ratio, due to less bank stabilization (if compared to post-Silurian examples). Since the channel belts did not show strong avulsion rates, due the combination of aggradation pattern of filling of the basin and perhaps a buffer effect of the wider levee system, fine grained floodbasin deposits would be deposited in the more distal reaches of the alluvial system. The occurrence of dessication features points to subaerial exposure of the substrate, yet with some available moisture, that would guarantee the conditions for the formation of paleosols. Also, the paleosols suggests that some of the flat surfaces would be long lived, and that the rate o deposition in the floodbasin would not be high, as expected for a floodbasin environment. In this scenario, the regular input of moisture to the alluvial valley would imply in perennial water flow in the main channel belt, that in more extreme precipitation could reach the distal parts of the floodbasin, with water input through the ribbon channels running on the floodplain. However, only in extreme flooding events would deposition be significant in the floodbasin, implying in some amount of shifting of the drainage system, with avulsion of active channel and reactivation of abandoned channel in different parts of the basin. 
Froude Transcritical and Supercritical Structures (sensu Fielding et al., 2011) occur in different facies associations in the Varzinha Formation, characterizing a distribution in different environments. FTSS in active bars in the channel belt are interpreted as resulting from near bank-full flow over the bars. FTSS in floodplain environments and channel-proximal sand bodies is interpreted as the result of local high-slope environments with flood-basin-directed flow fed from the proximal alluvial ridges, including the main channel-belt and minor channels flowing across the floodplains. Coarser-grained pebbly sandstones with FTSS are interpreted as distal flows fed from alluvial-fan channels that become unconfined in the alluvial plain. Therefore, in all three environments, FTSS is related to local high-discharge events, combined either with local high slope gradients or with particular conditions interfering with the channelized flow (the bar tops functioning as obstacles).

\section{Discussion}

Pre-vegetation alluvial sedimentary environments have been extensively considered to represent a particular type of fluvial deposit (Long, 1978, 2006), which would have its unique traits derived from the absence of the prominent and varied vegetation cover found in post-Silurian settings, which is understood as an important agent of transformation and organization of the overall fluvial architecture (e.g., Davies et al., 2011; Gibling \& Davies, 2012). However, attributing one single depositional model do the entire Precambrian and Early Paleozoic fluvial record seems to be an oversimplification, considering the possibilities of continental environment variability during a time period spanning most of the geological record (Long, 2011). Also, it is important to consider that in spite of the commonly assumed bare and inhospitable Precambrian landscape, recent contributions point to a progressive change in the landscape driven by the colonization of the surface by microorganisms (Kennedy et al., 2006; Knauth \& Kennedy, 2009; Kennedy \& Droser, 2011), which might have impacted the architecture of alluvial deposits.

In this context, a better understanding of the characteristics of pre-vegetation floodplains has the potential to improve our understanding of the continental landscape through the Precambrian and Early Paleozoic, and potentially impact the comprehension of the way we understand the working of modern fluvial systems.

The model proposed in this work has interesting implications for a number of similar cases, were pre-vegetation fluvial deposits are rich in tabular bodies of planar or low-angle 
stratified sandstone, sometimes interbedded with trough cross-stratified sandstone (i.e. sheet-like sandstone). This type of facies association is described here as part of the alluvial plain, and positioned laterally to active channels or channel-belts. Additionally, the sand bodies formed in this unchannelized setting would extend much farther into the floodplain, with their distal reaches being interbedded to tabular layers of mudstone, characteristic of the floodbasin environment.

This facies association was described by Marconato et al. (2014) as a possible analogue for levee deposits. The authors, however, did not imply that this type of facies association would extend farther into the floodplain, positioning the tabular sandstone as marginal deposits to channel belts,resembling levees, but with larger width to height ratios. On the other hand, the example of the Varzinha Formation suggests that the tabular sandstone bodies would extend much farther into the floodplain, being one of the main constituents of the floodplain deposits. Unchannelized flow during strong floods would explain the transport of bedload material far from channels or channel-belts, but they do not seem to be the only path for bedload, as the existence of smaller Channel Forms, with its own levees, suggests that scouring on the top of the Tabular sandstone would be crevasse channels, which could run down to floodbasin, representing an efficient agent for bedload transport from the main channels. In this way, the input of sand would not require extreme and catastrophic flooding events.

The interpretation of tabular sandstone deposits as part of floodplains imply that much of the record of the Varzinha Formation is formed by floodplain deposits. This contrasts with former interpretations of the sedimentary environment of these sedimentary rocks, which were prior explained as deposits of ephemeral lake beds (Paim, 1994) or the record of an ephemeral fluvial system (Almeida, 2005; Almeida et al., 2009). A common place between this contrasting models is the ephemeral character of the processes for most of the deposits of the sedimentary unit, specially considering the tabular sandstone deposits.

In comparison to previous studied cases, the floodplain deposits of the Varzinha Formation share a number of common features, which may help to identify other examples of pre-vegetation floodplain deposits. The better preservation of small-scale sedimentary structures, such as climbing ripples in very fine sandstone and siltstone, are one of the most common features among the published examples (Sønderholm \& Tirsgaard, 1998; Hadlari et al., 2006; Fralick \& Zaniewski, 2012; Marconato et al., 2014), and it is arguably a two-fold effect of the lack of plant cover, as the absence of vegetation-induced baffling would allow the formation of the more delicate bedforms, which are more likely to be preserved without 
the root bioturbation. Also, the occurrence of planar and low-angle cross stratified sandstone are commonly found among the described ancient floodplain deposits (Sønderholm \& Tirsgaard, 1998; Fralick \& Zaniewski, 2012; Marconato et al., 2014), as well as the thinly laminated mudstone beds. Still, in spite of the overall better preservation potential of sedimentary structures when compared to post-Silurian examples, Fralick \& Zaniewski (2012) described loss of sedimentary structure in the form of convoluted facies, which were attributed to a combination of fluidization and liquefaction, while Marconato et al. (2014) described loss of sedimentary structure due to paleosol formation.

If by the one hand the identification and description of floodplain deposits are dismissed or downplayed, on the other hand, studies aimed at the identification and description of paleosols in the Precambrian and Early Paleozoic often claimed floodplain environments as sites of formation of part of the described paleosols (e.g., Retallack, 1986, 2008, 2012; Retallack et al., 2014).

The suggestion that part of the pre-vegetation fluvial sedimentary deposits described as ephemeral fluvial systems might be in fact the record of coarse grained floodplains (see Alexander \& Fielding (2006) for an example of coarse grained floodplain in modern environments), can have a number of impacts in the way alluvial environments are seen. The often claimed high discharge variation of channelized environments may, at least in some cases, be an artifact of the description of overbank sandstone deposits as part of the channelized deposits. Part of the interpretation of ephemeral flow in fluvial systems is based, as noted by North \& Davidson (2012), on the assumption that tabular sandstone with low-angle cross-stratification or planar stratification is the product of "flash floods". In fact FTSS occur in a wide range of alluvial environments, including even channelized flows. On the other hand, the abundance of sandy deposits in pre-vegetation environments was most probably favored by the lower flow resistance of non-vegetated flood-plains when compared to their modern analogues, resulting in faster water flow and more efficient sediment transport for the same discharge.

\section{Final Remarks}

The sedimentary deposits from the Varzinha Formation record an alluvial plain with a system of braided channels related to coarse-grained floodplains. The most important features of this alluvial environment are the plane bedded sandstones, that are arguably the most common facies association in the alluvial environment, and also the tabular mudstone facies 
association, that although not as voluminous as the sandstone deposits, are still frequent enough to be called as one of the conspicuous characteristics of the sedimentary unity (Paim, 1994; Almeida, 2005). The depositional model for the Varzinha Formation depicts a pre-vegetation alluvial environment with an system of braided fluvial channels concentrated close to eastern border of the rift basin, with other minor channel running elsewhere in the basin. The braid channels were bordered by sand bodies of the proximal floodplain environment, composing broad alluvial ridges. The more distal reaches of the floodplain deposits show a decrease in the grain size of the sandstone bodies, which are interbedded to fine grained floodbasin deposits, in areas not directly affected by the main channels, but that featured ribbon channels, which would be responsible for most of the sedimentary bedload input to the distal reaches of the floodplain.

The floodplain environment shows evidence of subaerial exposure, however without evidence of aridity or excessive drought, as often expected for pre-vegetation sedimentary deposits formed by ephemeral flooding. In fact, the floodbasin bears paleosol profiles that suggest a well drained environment, with availability of moisture that would be enough to prevent calcretization. Evidence of algal mats in the floodbasin deposits, in the form of sand chips and cracked mudstone, also suggests availability of water.

The existence of coarse grained floodplain deposits in pre-vegetation fluvial environments brings additional complexity to the models regarding Precambrian and Early Paleozoic continental sedimentary processes and products. The variability of environments found in the Varzinha Formation is in agreement with recent studies regarding pre-vegetation fluvial deposits (e.g., Long, 2011; Fralick \& Zaniewski, 2012; Marconato et al., 2014), which expands the complexity of Precambrian fluvial deposits beyond the monotonous sheet-like sandstone model usually attributed to the ancient record of fluvial sedimentation.

\section{References}

Alexander, J., \& Fielding, C. R. (2006). Coarse-grained floodplain deposits in the seasonal tropics: towards a better facies model. Journal of Sedimentary Research, 76(3-4): $539-556$.

Allen, J. P., Fielding, C. R., Gibling, M. R., \& Rygel, M. C. (2011). Fluvial response to paleo-equatorial climate fluctuations during the late Paleozoic ice age. Bulletin of the Geological Society of America, 123(7-8): 1524-1538.

Allen, J. P., Fielding, C. R., Rygel, M. C., \& Gibling, M. R. (2013). Deconvolving Signals of Tectonic and Climatic Controls From Continental Basins: An Example From the Late Paleozoic Cumberland Basin, Atlantic Canada. Journal of Sedimentary Research, 83(10): 
$847-872$.

Almeida, R. P. (2005). Tectônica e sedimentação do Ediacarano ao Ordoviciano: exemplos do Supergrupo Camaquã (RS) e do Grupo Caacupé (Paraguai Oriental). Tese de Doutoramento. Instituto de Geociências, Universidade de São Paulo, São Paulo.

Almeida, R. P., Janikian, L., Fragoso-Cesar, A. R. S., \& Fambrini, G. L. (2010). The Ediacaran to Cambrian rift system of southeastern South America: Tectonic implications. Journal of Geology, 118(2): 145-161.

Almeida, R. P., Janikian, L., Fragoso-Cesar, A. R. S., \& Marconato, A. (2009). Evolution of a rift basin dominated by subaerial deposits: The Guaritas Rift, Early Cambrian, Southern Brazil. Sedimentary Geology, 217(1-4): 30-51.

Almeida, R. P., Santos, M. G. M., Fragoso-Cesar, A. R. S., Janikian, L., \& Fambrini, G. L. (2012). Recurring extensional and strike-slip tectonics after the Neoproterozoic collisional events in the southern Mantiqueira province. Anais Da Academia Brasileira de Ciências, 84: 347-376.

Best, J. L., \& Bridge, J. S. (1992). The morphology and dynamics of low amplitude bedwaves upon upper stage plane beds and the preservation of planar laminae. Sedimentology, 39(5): 737-752.

Bridge, J. S. (2003). Rivers and Floodplains: forms, processes and sedimentary record. Blackwell Science Ltd.

Bristow, C. S. (1993). Sedimentary structures exposed in bar tops in the Brahmaputra River, Bangladesh. Geological Society, London, Special Publications, 75(1): 277-289.

Chemale Jr., F. (2002). Evolução Geológica do Escudo Sul-rio-grandense. In: HoLZ, M. \& DE Ros, L. F. (EDS.), Geologia do Rio Grande do Sul (p. 13-52). CIGO/UFRGS.

Davies, N. S., \& Gibling, M. R. (2010). Paleozoic vegetation and the Siluro-Devonian rise of fluvial lateral accretion sets. Geology, 38(1): 51-54.

Davies, N. S., \& Gibling, M. R. (2011). Evolution of fixed-channel alluvial plains in response to Carboniferous vegetation. Nature Geoscience, 4(9): 629-633.

Davies, N. S., Gibling, M. R., \& Rygel, M. C. (2011). Alluvial facies evolution during the Palaeozoic greening of the continents: Case studies, conceptual models and modern analogues. Sedimentology, 58(1): 220-258.

De Ros, L. F., Morad, S., \& Paim, P. S. G. (1994). The role of detrital composition and climate on the diagenetic evolution of continental molasses: evidence from the Cambro-Ordovician Gguaritas sequence, southern Brazil. Sedimentary Geology, 92(3-4): $197-228$.

Eriksson, P. G., Schieber, J., Bouougri, E., Gerdes, G., Porada, H., Banerjee, S., ... Sarkar, S. (2007). Classification of structures left by microbial mats in their host sediments. In: Schieber, J., Bose, P. K., Eriksson, P. G., BanerJee, S., SARKar, S., Altermann, W., \& CATUNEAU, O. (EDS.), Atlas of microbial mat features preserved within the clastic rock record (p. 53-71). Elsevier.

Fielding, C. R. (1986). Fluvial channel and overbank deposits from the Westphalian of the Durham coalfield, NE England. Sedimentology, 33(1): 119-140.

Fielding, C. R. (2006). Upper flow regime sheets, lenses and scour fills: Extending the range of architectural elements for fluvial sediment bodies. Sedimentary Geology, 190(1-4): $227-240$. 
Fielding, C. R., Allen, J. P., Alexander, J., \& Gibling, M. G. (2009). Facies model for fluvial systems in the seasonal tropics and subtropics. Geology, 37(7): 623-626.

Fielding, C. R., Allen, J. P., Alexander, J., Gibling, M. R., Rygel, M. C., \& Calder, J. H. (2011). Fluvial systems and their deposits in hot, seasonal semiarid and subhumid settings: modern and ancient examples. In: DAVIDSON, S. K., LELEU, S., \& NORTH, C. P. (EDS.), From River to Rock Record: The Preservation of Fluvial Sediments and Their Subsequent Interpretation (p. 89-111). SEPM Special Publication 97.

Fragoso-Cesar, A. R. S., Fambrini, G. L., Almeida, R. P., Pelosi, A. P. M. R., Janikian, L., Riccomini, C., Machado, R., Nogueira, A. C. R., Saes, G. S. (2000). The Camaquã extensional basin: Neoproterozoic to early Cambrian sequences in southernmost Brazil. Revista Brasileira de Geociências, 30(3): 438-441.

Fralick, P., \& Zaniewski, K. (2012). Sedimentology of a wet, pre-vegetation floodplain assemblage. Sedimentology, 59(3): 1030-1049.

Freitas, B. T., Almeida, R. P., Turra, B. B., Figueiredo, F. T., Marconato, A., Galeazzi, C. P., \& Carrera, S. C. (2013). Bar-top deposits and fluvial architecture. In: 10th International Conference on Fluvial Sedimentology (ICFS).

Gibling, M. R., \& Davies, N. S. (2012). Palaeozoic landscapes shaped by plant evolution. Nature Geoscience, 5(2): 99-105.

Godinho, L. P. S., Almeida, R. P., Marconato, A., Santos, M. G. M., \& Fragoso-Cesar, A. R. S. (2013). Análise de proveniência dos arenitos conglomeráticos do Grupo Guaritas (RS): implicações para o paleoclima e a paleogeografia da sub-bacia Camaquã Central no Eocambriano. Geologia USP. Série Cientifica, 13: 123-144.

Godinho, L. P. S., Almeida, R. P., Santos, M. G. M., Marconato, A., \& Fragoso-Cesar, A. R. S. (2013). Fácies sedimentares e elementos arquitetônicos das Formações Serra do Apertado e Pedra Pintada na Região das Minas do Camaquã - RS. Geologia USP. Série Cientifica, 13: 22-48.

Hadlari, T., Rainbird, R. H., \& Donaldson, J. A. (2006). Alluvial, eolian and lacustrine sedimentology of a Paleoproterozoic half-graben, Baker Lake Basin, Nunavut, Canada. Sedimentary Geology, 190: 47-70.

Hartmann, L., Schneider, J., \& McNaughton, N. (2008). Detrital Zircon U-Pb Age Data, and Precambrian Provenance of the Paleozoic Guaritas Formation, Southern Brazilian Shield. International Geology Review, 50(4): 364-374.

Janikian, L., Almeida, R. P., Fragoso-Cesar, A. R. S., Martins, V. T. S., Dantas, E. L., Tohver, E., ... D'Agrella-Filho, M. S. (2012). Ages (U-Pb \{SHRIMP $\}$ and $\{$ LA $\}$ ICPMS) and stratigraphic evolution of the Neoproterozoic volcano-sedimentary successions from the extensional Camaquã Basin, Southern Brazil. Gondwana Research, 21(2-3): 466-482.

Janikian, L., Almeida, R. P., Trindade, R. I. F., Fragoso-cesar, A. R. S., D’Agrella-Filho, M. S., Dantas, E. L., \& Tohver, E. (2008). The continental record of Ediacaran volcano-sedimentary successions in southern Brazil and their global implications. Terra Nova, 20(4): 259-266.

Kennedy, M., Droser, M., Mayer, L. M., Pevear, D., \& Mrofka, D. (2006). Late Precambrian oxygenation; inception of the clay mineral factory. Science (New York, N.Y.), 311(5766): 1446-9.

Kennedy, M. J., \& Droser, M. L. (2011). Early Cambrian metazoans in fluvial environments, evidence of the non-marine Cambrian radiation. Geology, 39(6): 583-586. 
Knauth, L. P., \& Kennedy, M. J. (2009). The late Precambrian greening of the Earth. Nature, 460(7256): 728-732.

Long, D. G. F. (1978). Proterozoic stream deposits: some problems of recognition and interpretation of ancient sandy fluvial systems. In: MiALl, A. D. (ED.), Miall, A.D. (Ed.), Fluvial Sedimentology. Can. Soc. Petrol. Geol., Calgary, Mem., vol. 5, pp. 313-342. (Vol. 5, p. 313-342). Calgary: Canadian Society Petroleum Geology.

Long, D. G. F. (2004). Precambrian rivers. In: ERIKSson, P. G., AltermanN, W., Nelson, D. R., Mueller, W. U., \& Catuneanu, O. (Eds.), The Precambrian Earth: Tempos and Events (p. 660-663). Amsterdam: Elsevier.

Long, D. G. F. (2006). Architecture of pre-vegetation sandy-braided perennial and ephemeral river deposits in the Paleoproterozoic Athabasca Group, northern Saskatchewan, Canada as indicators of Precambrian fluvial style. Sedimentary Geology, 190(1-4): 71-95.

Long, D. G. F. (2011). Architecture and Depositional Style of Fluvial Systems before Land Plants: A Comparison of Precambrian, Early Paleozoic, and Modern River Deposits. In: DAVIDSON, S. K., S., L., \& NorTh, C. P. (EDS.), From river to rock record (Vol. 97, p. 37-62). SEPM Special Publication.

Maraschin, A. J., Mizusaki, A. M., Zwingmann, H., de Borba, A. W., \& Sbrissa, G. F. (2010). Illite authigenesis in sandstones of the Guaritas Allogroup (Early Paleozoic): Implications for the depositional age, stratigraphy and evolution of the Camaquã Basin (Southern Brazil). Journal of South American Earth Sciences, 29(2): 400-411.

Marconato, A., Almeida, R. P., Santos, M. G. M., Nóbrega, J. E. S., \& Souza, R. B. (2009). Alluvial-eolian interaction in a Cambrian rift margin: the Pedra das Torrinhas and Pedra Pintada formations (Guaritas Group, RS). Anais Da Academia Brasileira de Ciências, 81(4): 819-836.

Marconato, A., Almeida, R. P., Turra, B. B., \& Fragoso-Cesar, A. R. S. (2014). Pre-vegetation fluvial floodplains and channel-belts in the Late Neoproterozoic-Cambrian Santa Bárbara Group (Southern Brazil). Sedimentary Geology, 300: 49-61.

Miall, A. D. (1985). Architectural-element analysis: A new method of facies analysis applied to fluvial deposits. Earth-Science Reviews, 22(4): 261-308.

Mjøs, R., Walderhaug, O., \& Prestholm, E. (1993). Crevasse splay sandstone geometries in the Middle Jurassic Ravenscar Group of Yorkshire, UK. Alluvial sedimentation (p. 167-184).

Nóbrega, J. E. S., Sawakuchi, A. O., \& Almeida, R. P. (2008). Minerais pesados das porções média e superior do Grupo Guaritas (Eocambriano, RS): considerações sobre a proveniência sedimentar. Revista Brasileira de Geociências., 38(3): 554-565.

Noffke, N. (2000). Extensive microbial mats and their influences on the erosional and depositional dynamics of a siliciclastic cold water environment (Lower Arenigian, Montagne Noire, France). Sedimentary Geology, 136(3-4): 207-215.

North, C. P., \& Davidson, S. K. (2012). Unconfined alluvial flow processes: Recognition and interpretation of their deposits, and the significance for palaeogeographic reconstruction. Earth-Science Reviews, 111(1-2): 199-223.

Oliveira, C. H. E., Junior, F. C., Jelinek, A. R., Bicca, M. M., \& Philipp, R. P. (2014). U-Pb and $\mathrm{Lu}-\mathrm{Hf}$ isotopes applied to the evolution of the late to post-orogenic transtensional basins of the Dom Feliciano belt, Brazil. Precambrian Research, 246: 240-255. 
Paim, P. S. G. (1994). Depositional Systems and Paleogeographical Evolution of the Camaquã and Santa Bárbara Basins, Brazil. Oxford.

Paim, P. S. G. (1996). O sistema desértico úmido Pedra Pintada (cambro-ordoviciano do RS). In: XXXIX Congresso Brasileiro de Geologia (Vol. 2, p. 207-209). Salvador, BA.

Paim, P. S. G., \& Scherer, C. M. S. (2007). High-resolution stratigraphy and depositional model of wind- and water-laid deposits in the ordovician Guaritas rift (Southernmost Brazil). Sedimentary Geology, 202(4): 776-795.

Paola, C., Heller, P. L., \& Angevine, C. L. (1992). The large-scale dynamics of grain-size variations in alluvial basins I - Theory. Basin Research, 4: 73-90.

Paola, C. P. (2000). Quantitative models of sedimentary basin filling. Sedimentology, 47(s1): $121-178$.

Reesink, A. J. H., \& Bridge, J. S. (2007). Influence of superimposed bedforms and flow unsteadiness on formation of cross strata in dunes and unit bars. Sedimentary Geology, 202(1-2): 281-296.

Reesink, A. J. H., \& Bridge, J. S. (2009). Influence of bedform superimposition and flow unsteadiness on the formation of cross strata in dunes and unit bars - Part 2, further experiments. Sedimentary Geology, 222(3-4): 274-300.

Reesink, A. J. H., \& Bridge, J. S. (2011). Evidence of bedform superimposition and flow unsteadiness in unit-bar deposits, South Saskatchewan river, Canada. Journal of Sedimentary Research, 81(11-12): 814-840.

Retallack, G. J. (1986). Reappraisal of a 2200 Ma-old paleosol near Waterval Onder, South Africa. Precambrian Research, 32(2-3): 195-232.

Retallack, G. J. (2001). Soils of the past: an introduction to paleopedology. Blackwell Science Ltd.

Retallack, G. J. (2008). Cambrian paleosols and landscapes of South Australia. Australian Journal of Earth Sciences, 55: 1083-1106.

Retallack, G. J. (2012). Were Ediacaran siliciclastics of South Australia coastal or deep marine? Sedimentology, 59(4): 1208-1236.

Retallack, G. J., Marconato, A., Osterhout, J. T., Watts, K. E., \& Bindeman, I. N. (2014). Revised Wonoka isotopic anomaly in South Australia and Late Ediacaran mass extinction. Journal of the Geological Society.

Santos, M. G. M., Almeida, R. P., Godinho, L. P. S., Marconato, A., \& Mountney, N. P. (2014). Distinct styles of fluvial deposition in a Cambrian rift basin. Sedimentology, 61(4): 881-914.

Santos, M. G. M., Almeida, R. P., Mountney, N. P., \& Fragoso-Cesar, A. R. S. (2012). Seismites as a tool in the palaeoenvironmental reconstruction of fluvial deposits: The Cambrian Guarda Velha Formation, southern Brazil. Sedimentary Geology, 277-278: $52-60$.

Scherer, C. M. S., Paim, P. S. G., \& Melo, M. A. (2003). Estratigrafia de alta resolução em sucessões flúvio-eólicas: o exemplo do Alogrupo Guaritas (Bacia do Camaquã) na localidade da Pedra Pintada, Rio Grande do Sul, Brasil. In: I Encontro sobre a estratigrafia do Rio Grande do Sul: Escudo e Bacias (p. 99-103). Porto Alegre, RS.

Schieber, J. (2004). Microbial mats in the Siliciclastic Rock Record: a summary of diagnostic 
features. In: Eriksson, P. G., Altermann, W., Nelson, D., Mueller, W. U., Catuneanu, O., \& StRand, K. (EDS.), The Precambrian Earth: Tempos and Events (p. 663-672). Elsevier.

Schumm, S. A. (1981). Evolution and response of the fluvial system sedimentologic implications. In: ETHRIDGE, F. G. \& FlORES, R. M. (EDS.), Recent and nonmarine depositional environments: Models for exploration: Soc. Econ. Paleontologists and Mineralogists Spec. Pub. 31 (p. 19-29).

Tirsgaard, H., \& Øxnevad, I. E. I. I. (1998). Preservation of pre-vegetational mixed fluvio-aeolian deposits in a humid climatic setting: an example from the Middle Proterozoic Eriksfjord Formation, Southwest Greenland. Sedimentary Geology, 120(1-4): 295-317.

Tooth, S. (2000). Process, form and change in dryland rivers: a review of recent research. Earth-Science Reviews, 51: 67-107.

Tooth, S. (2005). Splay Formation Along the Lower Reaches of Ephemeral Rivers on the Northern Plains of Arid Central Australia. Journal of Sedimentary Research, 75(4): 636-649. 


\title{
7. Deposition and preservation of fine grained facies in a Mesoproterozoic river system: the case of the Tombador Formation, Northeastern Brazil.
}

\author{
Marconato, A.; Turra, B.B.; Almeida, R.P.; Freitas, B.T.
}

\begin{abstract}
Preservation of mud in pre-vegetation fluvial successions is poorly documented, and the prevailing model for these systems predicts dominance of bed load streams, low production of fine-grained sediments and bypass of fines to distal basins. The Mesoproterozoic Tombador Formation includes sedimentary successions deposited in a fluvial setting. This fluvial system is characterized by three different facies associations: (i) channel forms filled by up to five meters thick fluvial bars, (ii) tabular sandstones lateral to the channels and pinching out towards (iii) floodplain deposits with tabular sandstone and minor siltstone beds. The lateral and vertical relations of the three facies associations were assessed through large scale outcrops, which enabled the interpretation of a fluvial environment formed by braided bars migrating inside channel belts, that passed laterally to tabular sandstone deposited in unconfined environments, and them into sandstone and siltstone tabular deposits with evidence of occasional subaerial exposure, in distal floodbasin setting. The interpreted sedimentary environment, one of braided fluvial channels bordered by coarse grained floodplain deposits, contribute to the recognition of the variability of local environments in ancient alluvial plains.
\end{abstract}

\section{Introduction}

Floodplain deposits have historically received less attention than channel-belt deposits in the development of facies models for alluvial plains. However, since the nineties floodplains started to gather the interest of the scientific community, mainly driven by the growing interest in the study of paleosols and proxies for climate change (Miall, 1996). If by the one hand comprehensive facies models for floodplains are scarce (e.g., Fielding, 1984, 1986), on the other hand the existence of systematic descriptions for such sedimentary environments in pre-Cambrian deposits are nearly non-existent, leading to models considering fluvial systems devoid of expressive floodplains during the Precambrian (e.g., 
Schumm, 1968; Cotter, 1978; Long, 1978, 2006; Eriksson et al., 2006).

Related to the lack of systematic studies of flood-plains in Precambrian sedimentary successions is the common assumption that pre-vegetation rivers were essentially ephemeral (e.g., Schumm, 1968; Cotter, 1978; Long, 1978), and therefore that there was no long-lasting distinction between channel-belt and other parts of the alluvial system, given that all the sedimentation would take place in episodic floodouts, similarly to what happens in modern alluvial fan systems (e.g., Eriksson et al., 2006). Additionally, other assumptions, such as weak to non-existent weathering and the reduced production of clay minerals before the evolution of land plants, corroborated the idea that Precambrian continental deposits are essentially poor in fine grained deposits, thus favoring the interpretation of marine or coastal environments to most of the fine-grained deposits of pre-Silurian age. Nevertheless, there are abundant descriptions of paleosols in favor of varied weathering conditions throughout the Precambrian and early Paleozoic (e.g., Retallack \& Krinsley, 1993; Retallack \& Mindszenty, 1994; Beukes et al., 2002; Driese et al., 2007; Retallack, 2008), and the improvement of sedimentary models regarding pre-vegetation alluvial systems (Long, 2006; Davies et al., 2011; Gibling \& Davies, 2012; Santos et al., 2014) suggest the possibility that floodplains were a much more important part of alluvial plains than previously thought (Allen \& Williams, 1982; Sønderholm \& Tirsgaard, 1998; Love \& Williams, 2000; Fralick \& Zaniewski, 2012; Marconato et al., 2014)

The present work focus on the identification of the modes of deposition and preservation of fine-grained facies in Precambrian continental depositional systems, through the description and interpretation of the Mesoproterozoic Tombador Formation in Northeastern Brazil, which allows both the detailed study of sedimentary facies associationsand the large-scale mapping of geometries and architectural elements on magnificent exposures. . This gives the opportunity to identify sites of fine grained deposition not only in floodplain environments, but also inside the channel belt, which suggests a much more complex fluvial environment for Mesoproteroic rivers than usually stated for deposits of this age.

\section{Geological Setting and Stratigraphy}

The Espinhaço Range in central Brazil comprises a thousands of kilometers long, N-S trending physiographic element composed mostly by precambrian sedimentary rocks (Espinhaço Supergroup) deposited on the São Francisco Craton and weakly deformed during 


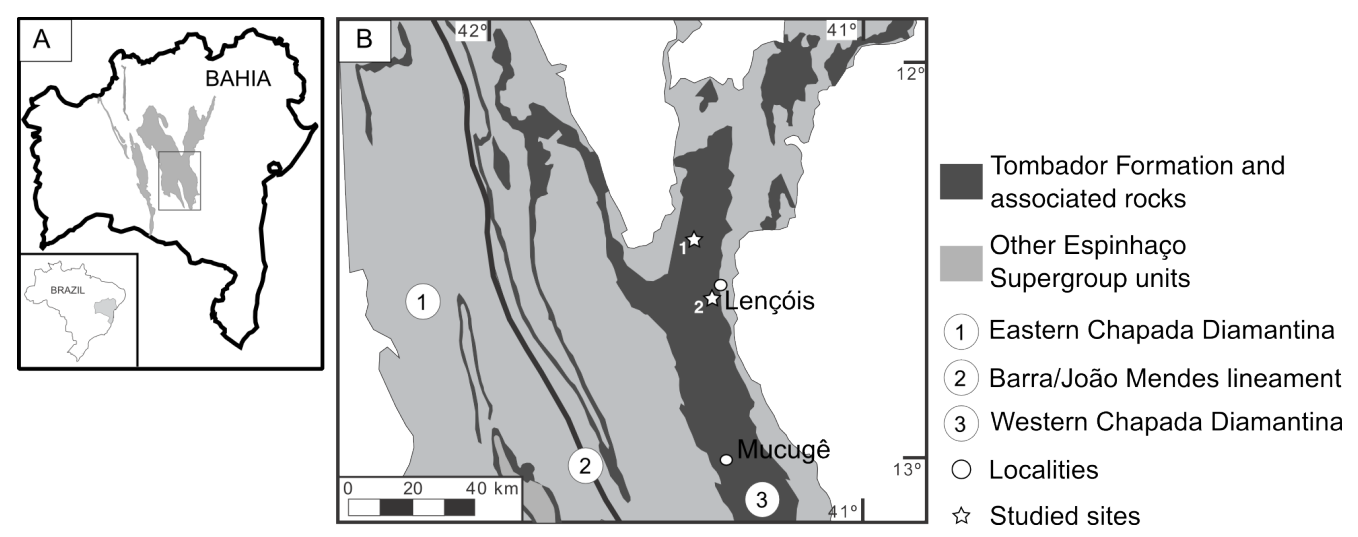

Fig. 1: Localization of the study area. (A) Bahia State with Espinhaço Range highlited (Espinhaço Supergroup); (B) Geological sketch of the Tombador Formation. The study location 1 comprises the Pai Inácio and Brejões Hill (Fig. 2, 3, and 6 ); the location 2 is south of Lençóis (see Fig. 4).

the Brasiliano Orogenic events that took place during the Neoproterozoic. This study is focused on the northern portion of the Espinhaço Range, which comprises the Chapada Diamantina Group (Fig. 01), interpreted as the record of a Mesoproterozoic intracratonic basin (e.g., Dominguez, 1993; Martins et al., 2008). The Chapada Diamantina Group is constituted, from base to top, by the Tombador (mostly continental successions), Caboclo (coastal and marine successions) and Morro do Chapéu (continental successions) formations, following Pedreira (1997). The western flank of the Chapada Diamantina range reveals the Tombador Formation deposited upon a discordance on siliciclastic rocks that comprise the record of a previous rift basin, recorded as the Rio dos Rémedios and Paraguassu groups (Martins et al., 2008), while on the eastern flank of the Chapada Diamantina ranges, the deposits of Tombador Formation rest directly on an unconformity with the Archean basement.

The characteristic mesa shaped ranges of the Chapada Diamantina physiography are sustained by the sedimentary succession of the Tombador Formation, which is up to $400 \mathrm{~m}$ thick in the study area. It has been interpreted as the product of sedimentation in continental settings, comprising eolian, fluvio-eolian, and alluvial-fan environments (e.g., Otero et al., 1989; Bomfim et al., 1990; Dominguez, 1993; Pedreira, 1997). The most common facies associations are aeolian sandstones at the base of the succession, and fluvial sandstones, interbedded with conglomeratic beds near the eastern basin border, in the middle and upper sections of the Tombador Formation. Mudstone facies are rare, and feature minor intercalation of fluvial sandstone and conglomeratic facies. Near the top of the formation, boulder sized conglomerates occur as expressive lenses.

The studied outcrops are located in the region of the Chapada Diamantina National Park, near the Lençois and Mucugê localities, and the Pai Inácio Hill, and are representative of the middle and upper successions of the Tombador Formation. 


\section{Examples from the Tombador Formation.}

The most common fluvial deposits in the Tombador Formation are characterized by stacked lenses of cross-bedded sandstones, which are decimeters to few meters thick and laterally continuous for tens to hundreds of meters, resulting in an overall architecture that can be attributed to a "sheet-braided style" (e.g., Cotter, 1978). These deposits are mostly coarse sandstones, often with sparse pebbles and pebble-rich lags. Cross-bedded conglomerate with rounded and imbricated clasts composed mainly of quartzite are restricted to exposures near the eastern basin border. These are most probably representative of the high slope gradient reaches of the system.

Three facies associations can be recognized in these particular successions (facies descriptions and interpretations are provided in the Table 01 ).

\subsection{Facies association 1}

\section{Description}

The most abundant facies association in the Tombador Formation is characterized by medium to coarse-grained sandstones without pebbles and only rarely bearing granules, with abundant tabular and trough cross-stratification of facies S1 and S2 in sets 10 to $40 \mathrm{~cm}$ thick. The surfaces limiting the sandstone sets are generally inclined at angles ranging from a few degrees up to $15^{\circ}$, oriented in directions preferably parallel to the dip of the cross-strata. These inclined cosets are part of up to $5 \mathrm{~m}$ thick compound cross-sets bounded at their bottoms by concave up surfaces, which may be tens to hundreds of meters wide, forming channel bodies. These channels are locally stacked (Fig. 02), but are often found to cut deposits of the other two facies associations, described below. These compound cross-stratified deposits show frequent lateral and upward transitions into Facies Association 2.

\section{Interpretation}

The occurrence of the cross-stratified deposits of facies S1 and S2 inside channel forms, associated to the dominance compound cross-sets, which are up to $5 \mathrm{~m}$ thick, and the unidirectional paleocurrents suggest an origin in fluvial sand bars migrating inside channels. The common coincidence of the attitude of inclined bounding surfaces and paleocurrent directions, indicated by the sedimentary structures indicates that downstream accretion was the main mechanism of bar growth and migration, suggesting a fluvial style characteristic of braided systems. 
Table 01: Descritption and interpretation of sedimentary facies identified in the studied successions.

\begin{tabular}{|l|l|l|l|}
\hline code & facies & description & interpretation \\
\hline S1 & $\begin{array}{l}\text { Trough } \\
\text { cross-stratified } \\
\text { sandstone }\end{array}$ & $\begin{array}{l}\text { Medium to coarse grained sandstone in } 10 \text { to } 40 \text { centimeter thick sets, with trough } \\
\text { cross-stratification. Locally it may have sparse granules and pebbles. }\end{array}$ & $\begin{array}{l}\text { Migration of subaqueous dunes with sinuous crests under } \\
\text { lower-stage flow. }\end{array}$ \\
\hline S2 & $\begin{array}{l}\text { Tabular } \\
\text { cross-stratified } \\
\text { sandstone }\end{array}$ & $\begin{array}{l}\text { Medium grained sandstone in sets } 10 \text { to } 30 \text { centimeter thick sets, with tabular } \\
\text { cross-stratification, slightly tangential at the base. }\end{array}$ & $\begin{array}{l}\text { Migration of subaqueous dunes with nearly straight crests } \\
\text { under lower-stage flow. }\end{array}$ \\
\hline S3 & $\begin{array}{l}\text { Planar stratified } \\
\text { sandstone }\end{array}$ & $\begin{array}{l}\text { Fine to medium grained sandstones with even, parallel bedding Parting lineation } \\
\text { can be found on bedding planes. }\end{array}$ & $\begin{array}{l}\text { Migration of low-amplitude bedforms (bedload sheets } \\
\text { sensu Bridge 2003) in upper-stage flows. }\end{array}$ \\
\hline S4 & $\begin{array}{l}\text { Sandstone with } \\
\text { climbing-ripples }\end{array}$ & $\begin{array}{l}\text { Fine to medium grained sandstones, often micaceous, with critical to supercritical } \\
\text { asymmetric climbing ripples. }\end{array}$ & $\begin{array}{l}\text { Migration of ripples due to unidirectional flow with high } \\
\text { rate of deposition from suspension. }\end{array}$ \\
\hline S5 & Massive sandstone & $\begin{array}{l}\text { Beds of structureless sandstone with variable thickness, from less than 5 cm up to } \\
30 \text { cm }\end{array}$ & $\begin{array}{l}\text { Sudden deposition of sand carried in hyper-concentrated } \\
\text { flows }\end{array}$ \\
\hline M1 & Laminated siltstone & $\begin{array}{l}\text { Reddish mudstone deposits with discontinuous lamination. Lamination is often } \\
\text { planar, but climbing-ripple cross-lamination can also be found. }\end{array}$ & $\begin{array}{l}\text { Settling of fine-grained particles in slowly moving or } \\
\text { episodically stagnant water. }\end{array}$ \\
\hline M2 & Massive siltstone & $\begin{array}{l}\text { Beds of massive mudstone with variable thickness, ranging from less than 1 cm to } \\
\text { more than } 20 \mathrm{~cm} .\end{array}$ & $\begin{array}{l}\text { Settling of fine-grained particles in water bodies with } \\
\text { negligible current. }\end{array}$ \\
\hline M3 & $\begin{array}{l}\text { Mud-cracked } \\
\text { mudstone }\end{array}$ & $\begin{array}{l}\text { Beds of massive mudstone with mudcracks filled by medium to coarse sand. } \\
\text { dessication of clay minerals and infilling of cracks by } \\
\text { airborne sand. }\end{array}$ \\
\hline
\end{tabular}




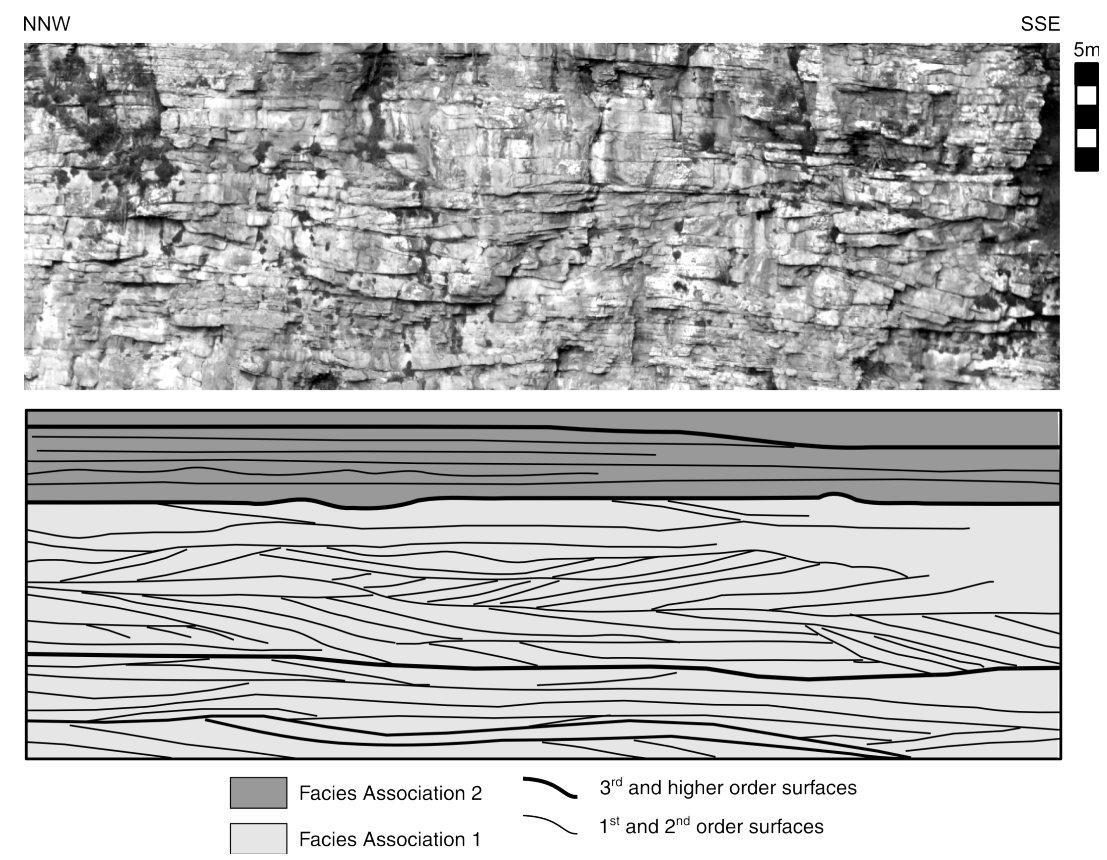

Fig. 2: Architecture of the Facies Association 1, showing stacked channels filled with compound cross-bed sets, toped by the tabular beds of Facies Association 2, as seen in the Brejões Hill.

\subsection{Facies association 2}

\section{Description}

Sandstone deposits with similar composition and grain size to those from Facies Association 1 are organized in stacked tabular beds several decimeters to a few meters thick, dominated by cross-stratified sandstone of facies S1 and S2. The bounding surfaces are planar , with much lower angles than those found in the Facies Association 1. Plane-bedded fine to medium-grained sandstones of facies S3 are rarely found. The tabular sandstone beds are stacked in successions up to $10 \mathrm{~m}$ thick, and often transition upward or laterally from the channelized deposits of Facies Association 1 (Fig. 02). In the later case, they may gently dip outward from the channels or fill broad scours, that are shallower than the channels of Facies Association 1. Besides the lateral relation with the channel bodies, the tabular sandstone beds also show a transition into Facies Association 3 (below) (Fig. 03), characterized by the pinching out of the sandstone bodies, accompanied by a gradual increase in the frequency and thickness of siltstone beds.

Apart from the absence of pebbles and granules, this association closely resembles the tabular sandstone association that dominates the Tombador Formation on its eastern occurrences, where higher slope gradients are interpreted. Nevertheless, in the studied succession this association is restricted to occurrences between the channels of Facies Association 1 and successions of Facies Association 3 (Fig. 04). 


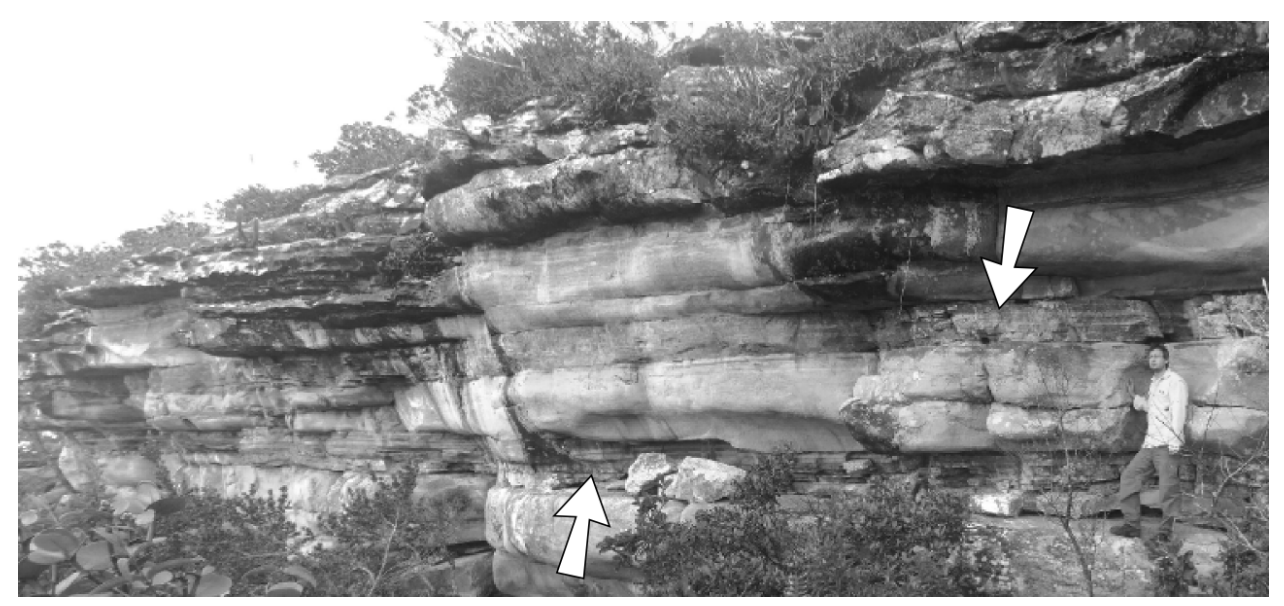

Fig. 03: Deposits of Facies Association 3, showing interbedding of continuous layers of sandstone facies S1, S3 and fine grained facies M1 and M2 (indicated by arrows). The coarser sandstone facies S1 and S2 on the top of the outcrop has affinities with Facies Association 1.

\section{Interpretations}

The tabular geometry of the sandstone beds of Facies Association 2 are remarkably similar to the sheet-like sandstone deposits frequently considered as dominant in Precambrian fluvial deposits (e.g., Cotter, 1978; Davies \& Gibling, 2011). The widespread occurrence of $\mathrm{S} 1$ and S2 facies indicates deposition by migrating dunes in subaqueous environments, however, the planar high order surfaces and tabular geometries are indicative of processes that took place on poorly channelized environments. Additionally, the rare occurrence of plane-bedded S3 facies may indicate change in flow conditions, that could be driven by the slope increments that are found close to channel bodies of Facies Association 1, in a context of formation of Froud Transcritial Sedimentary Structures (FTSS) (Fielding et al., 2011).

The lateral relation of the tabular sandstone beds of the Facies Association 2 with the channel bodies of Facies Association 1 is suggestive of formation of channel wings, with the tabular sandstone facies being product of flow over the marginal banks of the channel bodies.

\subsection{Facies association 3}

\section{Description}

Successions of interbedded fine to coarse-grained sandstones and siltstones compose tabular sediment bodies one to ten meters thick and laterally continuous for tens to a few hundreds of meters (Fig. 03). The sandstone beds show tabular geometries and are composed mainly of sandstones of facies S1 and S2, with subordinate sandstones of facies S3 and S5. The tabular sandstone beds show variable thickness, ranging from $20 \mathrm{~cm}$ to $50 \mathrm{~cm}$, being very similar to the tabular sandstone deposits that comprises the Facies Association 2. The siltstone beds generally comprise tabular layers with thickness ranging from 20 to $100 \mathrm{~cm}$, composed by climbing-ripple cross-lamination or low-angle cross lamination of facies M1, interbedded 

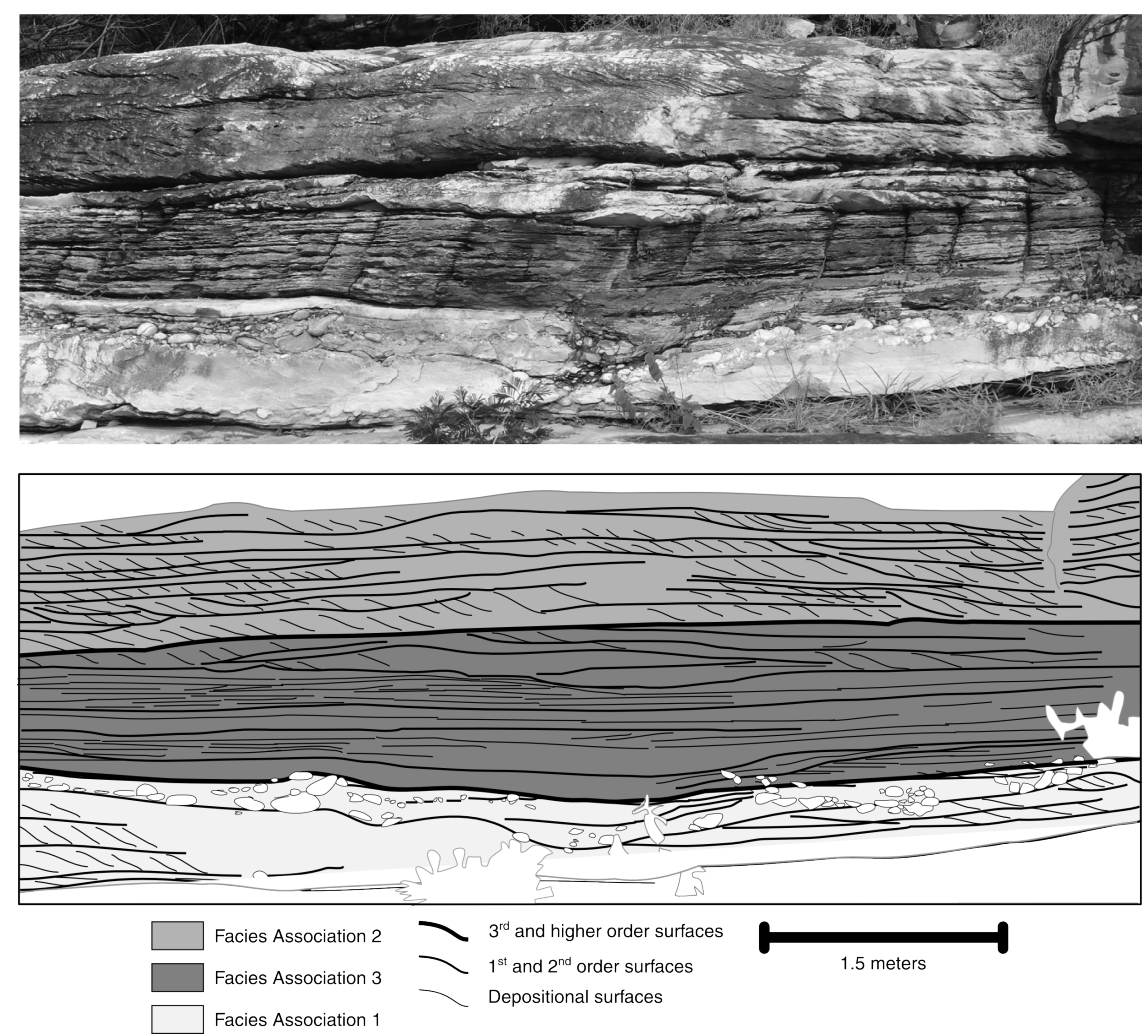

Fig. 04: Succession of coarse conglomeratic sandstone of Facies Association 1 (base of the picture and sketch), followed by deposits of Facies Association 3, with interbedding of facies S3 and M1, and Facies Association 2, with S1 and $\mathrm{S} 2$ facies.

to thin mudstone drapes on ripple marks of facies S4 (Fig. 05b), or with structureless siltstone of facies M2. Occasionally, sandy siltstone may be interbedded to sandstone with no apparent sedimentary structure (facies S5). Deposits of facies M1 and M2 locally cover and preserve bedforms in sandstone, including asymmetrical ripples and small dunes (Fig. 5a). Features indicative of sub-aerial exposure are rare, usually found on top of the siltstone beds, and comprise mudcracks and rain drop marks (facies M3) (Fig. 05c, 05d).

In some places the siltstone deposits are placed directly above imbricated pebble lags (Fig. 05e), with thicknesses equivalent to one cobble, resting on successions of Facies Association 1(Fig. 04). These successions transition laterally into Facies Association 2 and are often cut by channel bases of Facies Association 1. No laterally continuous flooding surface could be recognized in the studied succession.

\section{Interpretation}

The tabular beds of sandstone are very similar and probably formed by the same processes interpreted for Facies Association 2, being the record of sedimentation in poorly channelized overbank environments near the channel belt of Facies Association 1, probably being active only during major floods . The main difference between sand bodies of Facies Associations 2 and 3 resides in the smaller thickness of the tabular beds of sandstone in the 

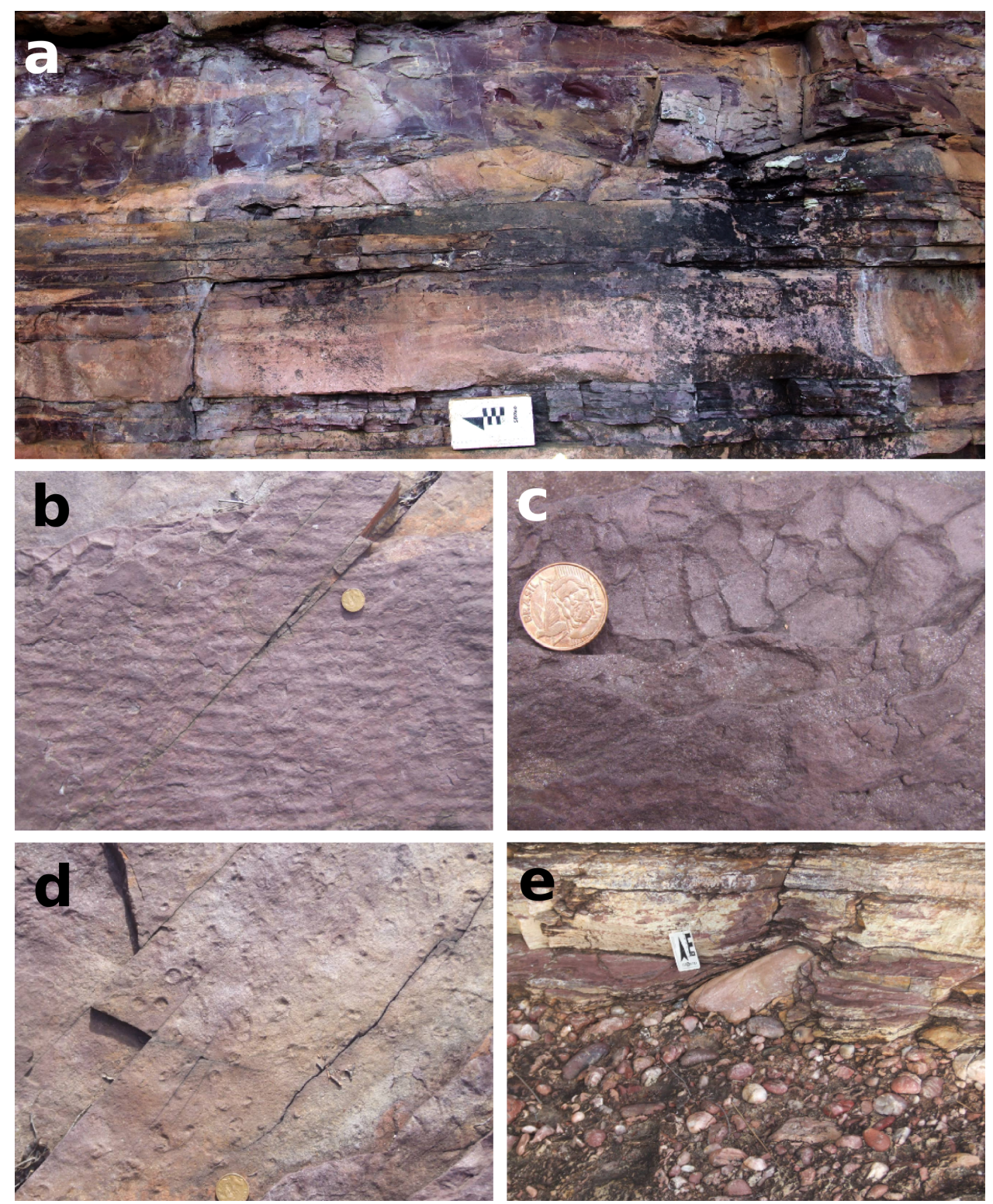

Fig. 05: a: mudcracks in fine grained the fine grained facies M3; b: ripple marks on top of facies M1; c: Plane bedded siltstone beds deposit directly above conglomeratic lag; d: rain drops marks recorded in siltstone; e: Detail of the Facies Association 3, showing interbedded purple siltstone of facies M2 and sandstone of facies S1, S3 and S4. Note preservation of subaqueous dune bedform some $40 \mathrm{~cm}$ above the scale. Scale is $19.0 \mathrm{~cm}$ long and $12.5 \mathrm{~cm}$ high.

latter, and the occasional deposition of climbing ripples or structureless sandstone, that could be the result of sudden loss of transport capacity of the flow, probably due to strong deceleration in lower reaches of the alluvial plain. This interpretation of a position near the flood basin is corroborated by the occurrence of the siltstone beds, which are the product of deposition of fine grained particles, settling from decelerating currents. . The strong reddish colors, combined with the presence of mudcracks and rain drop marks, are indicative of occasional subaerial exposure of these deposits, causing post-depositional oxidation of fine labile mineral grains..

The occurrence of siltstone beds directly on pebble lags imply in a different 
depositional setting. The imbricated conglomerate can be explained as the result of reworking and selective removal of sand graded particles of fluvial bar deposits by currents that did not have enough power to transport pebbles and cobbles, that are otherwise sparsely distributed in the fluvial facies. Thus, the pebble lags most probably developed on exposed surfaces of sand bars during lower stages. This interpretation suggests a bar top setting for deposition of the siltstones, either in small low-stage ponds or during prolonged periods of abandonment of areas of the alluvial plain due to chanel belt avulsion.

\section{Paleoenvironmental reconstruction}

The lateral correlation among the three facies associations (Fig. 06) indicates their origin in spatially related depositional environments. In Facies Association 1, erosional channel bases are covered by compound cross-strata that indicate deposition inside a few meters deep channels. The architecture of these bars suggest lateral amalgamation of up to four meters high individual bars formed mostly by downstream accretion. This succession passes upward and laterally to Facies Association 2, whose particular position between the other two associations suggests that it bordered the main active channels, representing bedform migration on shallow areas during floods. Similar deposits have been described for a Neoproterozoic succession (Marconato et al., 2014), and could represent the build-up of levees in this fluvial environment. The surfaces dipping from the channel bodies point to formation of a slope gradient from the channel banks to the floodplains, indicating the formation of alluvial ridges, although with less pronounced topography than the alluvial ridges found in modern fluvial systems (Collinson, 1996; Miall, 1996; Bridge, 2003).

The evidence of settling of fine-grained particles of Facies Association 3, with occasional subaerial exposure, and the lateral association with deposits interpreted as formed inside fluvial channels, point to an origin in distal reaches of fluvial floodplains, in floodbasin environments. The succession shows more abundant sandstones with current induced structures than most of the modern floodplain environments, possibly due to the reduction in flow velocity caused by the additional flow resistance due to the presence of vegetation on modern floodplains, as discussed in previous works regarding similar sedimentary settings (Fralick \& Zaniewski, 2012; Marconato et al., 2014).

Therefore, the interpreted model for the fluvial successions of the Tombador Formation is that of a braided river system characterized by several active individual bars that coalesced laterally inside hundreds of meters wide channel belts. These braided rivers were bordered by floodplains where sand beds intercalated minor fine-grained beds. The transition between the 


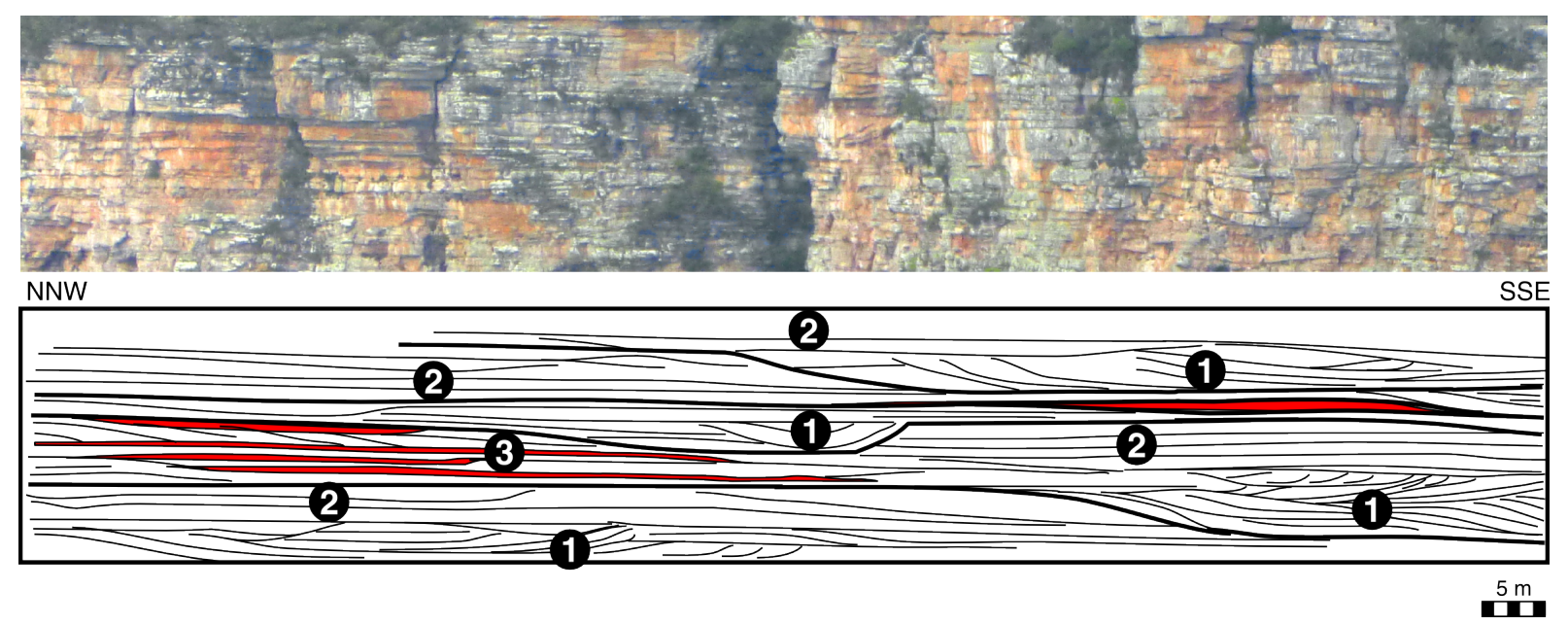

Fig. 6: The lateral relation among the three facies associations is illustrated by the western flank of the Brejões Hill, near Lençóis (BA). (1) Up to $5 \mathrm{~m}$ deep channel forms filled by sandstone in compound bars. (2) Tabular ("sheet-like") sand bodies in shallow areas lateral to the main channels. (3) Floodplain deposits with approximately $10 \%$ of fines.

channels and the floodplains is characterized by tabular beds of sandstone of Facies Association 2, which lower relief bed forms are an indication of an area of shallower flow. The few plane-bedded deposits found in this setting indicate the development of rapid currents due to the local slope gradient, inferred from the gradual thinning of the tabular sandstones towards the floodplains.

Previous interpretations of coastal depositional environments for the studied successions (Castro, 2002; Magalhães, 2002), did not recognize the channel-forms and considered the presence of mudstone and shallow water wave ripples (which are in fact very rare) as evidence of marine deposition. The alleged continuous flooding surfaces could not be recognized, being here interpreted as discontinuous floodplain deposits (Fig. 06). Additionally, minor heterolithic bedding and supposed tidal bundles, which are actually tabular cross strata with periodical dark drapes on the foresets defined by heavy minerals and not mud, were the basis for an interpretation of tidal influence. Wave ripples that are rarely found in Facies Association 3 are not necessarily evidence of coastal environments, since they can be formed in any water body with limited depth and subjected to wind action, thus, compatible with occasional ponding of water in a floodbasin setting.

\section{Discussion}

Previous units in which floodplains were recognized and described in pre-vegetation fluvial environments share a number of similarities, including the presence of fine grained facies 
interbedded to tabular sandstones. Besides the recognition of the importance of sand input to these unvegetated environments, wide spacing between outcrops or localized description of boreholes (Fralick \& Zaniewski, 2012; Marconato et al., 2014) have previously enabled only the indirect interpretation of the spatial relationships between the different facies associations identified in pre-Silurian alluvial plain successions.

In this context, the large scale exposures of the Tombador Formation enable the identification not only of the geometries of sedimentary facies associations, but also their lateral and vertical transitions and geometric relationships. The study of these exposures lead to the conclusion that, at least in the Tombador Formation, coarse grained floodplains are an important part of the tabular sandstones frequently considered as "sheet braided sandstones".

The datailed description of the exposures of the Tombador Formation also lead to the recognition of two important elements of the alluvial plain: areas of deposition of floodplain fines and multiple bars in channel fills. Despite the clear channelized geometry of the latter, their observation demands good exposure and detailed architectural analysis, and therefore the presence in other Precambrian successions cannot be discarded, notwithstanding the common assumption of poorly channelized flow (e.g., Cotter, 1978; Long, 1978; Eriksson et al., 2005). The observed features are in accordance with the recognition of a greater variability in Precambrian fluvial deposits, as recently proposed by Long (2011).

\section{Conclusions}

A fluvial environment characterized by coarse grained floodplain deposits lateral to fluvial channelized deposits is described for the Tombador Formation (Middle Proterozoic, Northeastern Brazil). This fluvial system is characterized by three different facies associations: (i) channel forms filled by up to five meters thick fluvial bars, (ii) tabular sandstones lateral to the channels and pinching out towards (iii) floodplain deposits with tabular sandstone and minor siltstone beds. The channel belt association is in fact similar to the dominant sheet-braided sandstones reported for many Precambrian successions, showing abundant meter-scale moderate to low angle inclined co-sets of cross-strata in monotonous stacked sandstone bodies, but channelized geometries are clearly observed, disfavoring the idea of poorly confined flow or rapid lateral migration of channel belts. The interpreted fluvial channel belt successions grade laterally into tabular cross-stratified sandstones and finally into sandstone and siltstone tabular deposits with evidence of occasional subaerial exposure. The later are interpreted as preserved floodplain deposits, that although poorly developed, indicate 
varied processes occurring at the alluvial plain.

The approach of interpretation of large scale exposures to constrain the lateral relations among different facies associations has a great potential to bring light to important questions regarding sedimentary processes and products in pre-vegetation fluvial environments. Accordingly, the study of facies associations other than the bed-load dominated channel belt deposits may greatly contribute to the recognition of the variability of local environments in ancient alluvial plains, thus enabling the testing of theoretical models and the improvement of the available database on continental deposits of different ages.

\section{References}

Allen, J. R. L., \& Williams, B. P. J. (1982). The Architecture of an Alluvial Suite: Rocks Between the Townsend Tuff and Pickard Bay Tuff Beds (Early Devonian), Southwest Wales Philosophical Transactions of the Royal Society of London. Series B, Biological Sciences, The Royal Society, 297(1085): 51-89.

Beukes, N. J. J., Dorland, H., Gutzmer, J., Nedachi, M., \& Ohmoto, H. (2002). Tropical laterites, life on land, and the history of atmospheric oxygen in the Paleoproterozoic. Geology, 30(6): 491-494.

Bomfim, L. F., Pedreira, A. J., \& Margalho, R. S. F. X. (1990). Geologia da Chapada Diamantina Oriental, Bahia (Folha Mucugê). In: Pedreira, A. J. \& MARGALHO, R. S. F. X. (EDS.), Programa de Levantamentos Geológicos Básicos do Brasil. Mucugê (Folha SD.24-V-C-II), Estado da Bahia; Texto Explicativo. (p. 25-73). Brasília: DNPM/CPRM.

Bridge, J. S. (2003). Rivers and Floodplains: forms, processess and sedimentary record. Blackwell Science Ltd.

Castro, M. R. (2002). Deformação Sin-deposicional em Depósitos Costeiros e Marinhos nas formações Tombador e Caboclo, Grupo Chapada Diamantina, BA. Revista Brasileira de Geociências, 32(2): 291-294.

Collinson, J. D. (1996). Alluvial Sediments. In: READING, H. G. (ED.), Sedimentary environments, processes, facies and stratigraphy (2nd ed., p. 37-82). Oxford. Blackwell Science.

Cotter, E. (1978). The evolution of fluvial style, with special reference to the central Appalachian Palaeozoic. In: MiAll, A. D. (ED.), Fluvial Sedimentology (Vol. 5, p. 361-384).

Davies, N. S., \& Gibling, M. R. (2011). Evolution of fixed-channel alluvial plains in response to Carboniferous vegetation. Nature Geoscience, 4(9): 629-633.

Davies, N. S., Gibling, M. R., \& Rygel, M. C. (2011). Alluvial facies evolution during the Palaeozoic greening of the continents: Case studies, conceptual models and modern analogues. Sedimentology, 58(1): 220-258.

Dominguez, J. M. L. (1993). O Cráton do São Francisco. In: J.M.L.DoMINGUEz \& A.MiSI (EDS.), (p. 137-159). Salvador: SBG-SGM-CNPQ.

Driese, S. G., Medaris Jr., L. G., Ren, M., Runkel, A. C., \& Langford, R. P. (2007).

Differentiating pedogenesis from diagenesis in early terrestrial paleoweathering surfaces formed on granitic composition parent materials. Journal of Geology, 115(4): 387-406. 
Eriksson, P. G., Bumby, A. J., Brümer, J. J., \& van der Neut, M. (2006). Precambrian fluvial deposits: Enigmatic palaeohydrological data from the c. 2-1.9 Ga Waterberg Group, South Africa. Sedimentary Geology, 190(1-4): 25-46.

Eriksson, P. G., Catuneanu, O., Sarkar, S., \& Tirsgaard, H. (2005). Patterns of sedimentation in the Precambrian. Sedimentary Geology, 176: 17-42.

Fielding, C. R. (1984). A coal depositional model for the Durham Coal Measures of NE England. Journal - Geological Society (London), 141(5): 919-931.

Fielding, C. R. (1986). Fluvial channel and overbank deposits from the Westphalian of the Durham coalfield, NE England. Sedimentology, 33(1): 119-140.

Fielding, C. R., Allen, J. P., Alexander, J., Gibling, M. R., Rygel, M. C., \& Calder, J. H. (2011). Fluvial systems and their deposits in hot, seasonal semiarid and subhumid settings: modern and ancient examples. In: DAVidson, S. K., Leleu, S., \& NorTH, C. P. (EDS.), From River to Rock Record: The Preservation of Fluvial Sediments and Their Subsequent Interpretation (p. 89-111). SEPM Special Publication 97.

Fralick, P., \& Zaniewski, K. (2012). Sedimentology of a wet, pre-vegetation floodplain assemblage. Sedimentology, 59(3): 1030-1049.

Gibling, M. R., \& Davies, N. S. (2012). Palaeozoic landscapes shaped by plant evolution. Nature Geoscience, 5(2): 99-105.

Long, D. G. F. (1978). Proterozoic stream deposits: some problems of recognition and interpretation of ancient sandy fluvial systems. In: MiALl, A. D. (ED.), Miall, A.D. (Ed.), Fluvial Sedimentology. Can. Soc. Petrol. Geol., Calgary, Mem., vol. 5, pp. 313-342. (Vol. 5, p. 313-342). Calgary: Canadian Society Petroleum Geology.

Long, D. G. F. (2006). Architecture of pre-vegetation sandy-braided perennial and ephemeral river deposits in the Paleoproterozoic Athabasca Group, northern Saskatchewan, Canada as indicators of Precambrian fluvial style. Sedimentary Geology, 190(1-4): 71-95.

Long, D. G. F. (2011). Architecture and Depositional Style of Fluvial Systems before Land Plants: A Comparison of Precambrian, Early Paleozoic, and Modern River Deposits. In: DAVIDSON, S. K., S., L., \& NORTH, C. P. (EDS.), From river to rock record (Vol. 97, p. 37-62). SEPM Special Publication.

Love, S. E., \& Williams, B. P. J. (2000). Sedimentology, cyclicity and floodplain architecture in the lower old red sandstone of SW wales. Geological Society Special Publication, (180): 371-388.

Magalhães, A. J. C. (2002). Estratigrafia da Formação Tombador, Mesoproterozóico, Chapada Diamantina, Bahia. In: Anais do $46^{\circ}$ Congresso Brasileiro de Geologia. Santos: Sociedade Brasileira de Geologia.

Marconato, A., Almeida, R. P., Turra, B. B., \& Fragoso-Cesar, A. R. S. (2014). Pre-vegetation fluvial floodplains and channel-belts in the Late Neoproterozoic-Cambrian Santa Bárbara Group (Southern Brazil). Sedimentary Geology, 300: 49-61.

Martins, A. A. M., Andrade Filho, E. L., Loureiro, H. S. C., Arcanjo, J. B. A., \& Guimarães, R. V. B. (2008). Geologia da Chapada Diamantina Ocidental (Projeto Ibitiara - Rio de Contas). (Série Arqu., p. 68). CBPM/CPRM.

Miall, A. D. (1996). The Geology of Fluvial Deposits: Sedimentary Facies, Basin Analysis and Petroleum Geology (p. 852). Springer. Berlin.

Otero, E. P., Dominguez, J. M. L., \& Lima, C. . (1989). Sedimentação fluvio-eólica no Proterozóico Médio, Formação Tombador, Grupo Chapada Diamantina, Estado da Bahia. In: Simpósio de Geologia 1, Belo Horizonte, Anais. (p. 212-217.). Belo Horizonte: SBG, 


\section{Boletim 10.}

Pedreira, A. . (1997). Sistemas Deposicionais da Chapada Diamantina Centro-oriental, Bahia. Revista Brasileira de Geociências, 27: 229-240.

Retallack, G. J. (2008). Cambrian paleosols and landscapes of South Australia. Australian Journal of Earth Sciences, 55: 1083-1106.

Retallack, G. J., \& Krinsley, D. H. (1993). Metamorphic alteration of a Precambrian (2.2 Ga) paleosol from South Africa revealed by backscattered electron imaging. Precambrian Research, 63(1-2): 27-41.

Retallack, G. J., \& Mindszenty, A. (1994). Well preserved late Precambrian paleosols from northwest Scotland. Journal of Sedimentary Research A: Sedimentary Petrology \& Processes, 64 A(2): 264-281.

Santos, M. G. M., Almeida, R. P., Godinho, L. P. S., Marconato, A., \& Mountney, N. P. (2014). Distinct styles of fluvial deposition in a Cambrian rift basin. Sedimentology, 61(4): 881-914.

Schumm, S. A. (1968). Speculations concerning the palaeo-hydraulic controls of terrestrial sedimentation. Geological Society of America Bulletin, 79: 1573-1588.

Sønderholm, M., \& Tirsgaard, H. (1998). Proterozoic fluvial styles: response to changes in accommodation space (Rivieradal sandstones, eastern North Greenland). Sedimentary Geology, 120(1-4): 257-274. 


\section{Discussão}

Planícies de inundação são compostas de uma gama diversa de processos e produtos sedimentares, mas ainda assim, não devem ser vistas como um sistema deposicional independente em si.Suas características, e até mesmo sua existência, são condicionadas e influenciadas pelo cinturão de canais e/ou pelos leques aluviais ao qual estão associadas. A própria definição apresentada no início deste trabalho, ao menos na forma que é apresentada, implica na dependência das planícies de inundação em relação aos sistemas de canais, pois as caracteriza como uma faixa de terreno adjacente ao canal fluvial, com relevo mais baixo e sazonalmente inundada e com depósitos formados por partículas sedimentares oriundas do canal principal (Schmnudde, 1968; Alexander \& Marriott, 1999; Bridge, 2003a), embora os autores também considerem importantes os processos autóctones. Apesar de compor uma definição bastante abrangente e adequada, ela dá margem para que se entenda a planície de inundação como uma parte passiva do sistema fluvial, como destacado por North \& Davidson (2012), ao atentar para a complexidade de processos sedimentares que podem ser encontrados em uma planície de inundação, incluindo ambientes complexos como diques marginais (Brierley et al., 1997), depósitos de rompimento de diques marginais (Bristow et al., 1999), e depósitos de bacia de inundação (Ethridge et al., 1981).

Os depósitos de planície de inundação neoproterozoicas apresentados no estudo de caso do Grupo Santa Bárbara apresentam alguns pontos em comum com o resultado de estudos semelhantes (Sønderholm \& Tirsgaard, 1998; Hadlari et al., 2006; Fralick \& Zaniewski, 2012), como a melhor preservação de estruturas sedimentares de pequena escala, como marcas onduladas, em relação a depósitos posteriores ao Siluriano, que podem ser fruto da ausência da interferência na sedimentação provocada pela presença de cobertura vegetal, assim como pela ausência de bioturbação. Outra característica em comum entre os exemplos citados são a ocorrência frequente de fácies de arenitos com estratificação cruzada de baixo-ângulo, com ocorrência um pouco mais limitada de arenitos com estratificação cruzada e com estratificação plana, além de pelitos laminados. Desta forma, os depósitos de fácies arenosas descritos pelos autores são bastante semelhantes, e mesmo a interpretação dos processos que geraram os depósitos arenosos não é muito dissimilar, sendo que em trabalhos anteriores os depósitos arenosos de planície de inundação são frequentemente interpretados como depósitos de rompimento de diques marginais (crevasse splays) (Sønderholm \& Tirsgaard, 1998; Hadlari et al., 2006; Fralick \& Zaniewski, 2012), embora pouca ou nenhuma menção seja feita à ausência ou presença de diques marginais. 
As principais diferenças entre o Grupo Santa Bárbara e os exemplos citados recaem sobre as características das fácies heterolíticas ou de granulação fina. Enquanto Fralick \& Zaniewski (2012) descrevem raras gretas de contração e intraclastos pelíticos, Sønderholm \& Tirsgaard (1998) e Hadlari et al. (2006) sequer mencionam o retrabalhamento de fácies pelíticas. Depósitos de pelitos gretados e intraclastos pelíticos são bastante comuns no Grupo Santa Bárbara. Neste aspecto reside um importante contraste entre os trabalhos publicados sobre planícies de inundação pré-vegetação e os exemplos do Grupo Santa Bárbara, uma vez que a ocorrência de fácies pelíticas, especialmente nos exemplos de Sønderholm \& Tirsgaard (1998) e Fralick \& Zaniewski (2012), são interpretados como depósitos formados em condições de clima mais úmido, com os depósitos de bacia de inundação raramento expostos a ressecamento subaéreo, ou com lençol freático próximo à superfície, enquanto que as fácies pelíticas do Grupo Santa Bárbara apresentam feições que indicam uma planície sujeita a climas mais secos, ou ao menos melhor drenada, pois não só apresentam feições que indicam ressecamento, mas também formação de paleossolos.

O estudo de caso referente à Formação Varzinha, no Grupo Guaritas, possui semelhanças com estudos de caso semelhantes na literatura (e.g., Sønderholm \& Tirsgaard, 1998; Fralick \& Zaniewski, 2012), como a boa preservação de estruturas sedimentares de pequena escala, como facies de pelitos finamente laminados, provável efeito direto da falta de cobertura vegetal, assim como a ocorrência de fácies de arenitos com estratificação cruzada de baixo-ângulo e estratificação planar, que são encontrados em todos os trabalhos anteriores, inclusive com interpretações semelhantes para os processos sedimentares. Ainda assim, a despeito da tendência de melhor preservação de estruturas sedimentares nestes exemplos de planícies pré-vegetação, Fralick \& Zaniewski (2012) descrevem processos responsáveis pela obliteração dos depósitos sedimentares, na forma de fácies convolutas, atribuídas a processos que combinam liquefação e fluidificação, devido a lençol freáticos próximo da superfície e carga sedimentar desigual na planície. Estruturas semelhantes são encontradas no Grupo Santa Bárbara, enquanto que no exemplo da Formação Varzinha não ocorrem fácies convolutas de forma expressiva. De forma diversa, a perda gradual de estruturas sedimentares, especialmente em depósitos de granulação mais fina, parece ser produto de formação de paleossolos.

O modelo de ambiente deposicional proposto para a Formação Varzinha tem implicações interessantes para o estudo de casos semelhantes, que contam com depósitos fluviais ricos em corpos sedimentares de geometria tabular e estratificação cruzadas de baixo-ângulo e estratificação plana horizontal, combinadas a depósitos de estratificação 
cruzada acanalada e tabular (i.e. sheet-like sandstone). Esse tipo de associação de fácies é aqui interpretada como parte da planície de inundação, com base nas relações espaciais destas associações de fácies com outras de interpretação mais direta, como depósitos do cinturão de canais e da bacia de inundação. A interpretação de que estes corpos de arenito seriam parte da planície de inundação, formados por fluxos não canalizados, indica que boa parte do registro da Formação Varzinha é formada por depósitos de planícies de inundação. A interpretação de ambiente deposicional contrasta com interpretações anteriores, que explicam os depósitos com leitos de lagos efêmeros (Paim, 1994) ou o registro de um sistema fluvial efêmero (Almeida, 2005; Almeida et al., 2009). Porém, nota-se um fio condutor em comum entre as propostas, que reside no caráter efêmero dos processos interpretados, especialmente se considerados os depósitos de arenito tabular.

Os depósitos estudados do Supergrupo Espinhaço, pertencentes à Formação Tombador, por outro lado, assemelham-se às sucessões arenosas pré-cambrianas consideradas como sheet-like sandstone deposits (e.g., Cotter, 1978; Long, 1978). O que chama a atenção porém, são camadas discretas de coloração avermelhada, que apresentam uma associação de fácies sugestiva de processos distintos dos responsáveis pelos depósitos arenosos, com maior abundância de facies com estratificação cruzada de baixo-ângulo, preservação de formas de leito e depósitos de decantação, além de feições indicativas de exposição subaérea. De forma distinta dos outros exemplos aqui estudados ou presentes na literatura sobre planícies de inundação pré-vegetação, parte destes depósitos de granulação mais fina são desenvolvidos sobre depósitos residuais (“lags”) conglomeráticos, o que sugerem ter se desenvolvido em topos de barras, ou de complexos de barras, como em ambientes de planícies de inundação modernos (e.g., Bridge, 2003). Embora parte destas fácies possam ser contextualizadas em topo de barras, é marcante sua semelhança com associações de fácies da mesma unidade que apresentam continuidade lateral extensa, e que em grandes cortes de afloramento são laterais a formas canalizadas. As considerações sobre deposição de estruturas de fluxos supercrítico ou transcrítico (FTSS sensu Fielding et al., 2009, 2011) na Formação Varzinha, com sua ocorrência tanto dentro de ambientes canalizados quanto em ambientes dominados por fluxo não canalizado, indica que esta associação de fácies, por si só pode não ser diagnóstica de um ambiente deposicional. Porém, a lateralidade dos depósitos ricos em FTSS em relação a corpos canalizados permite assumir a formação de ambientes não canalizados que tenham sua própria dinâmica sedimentar, e que podem ser portanto, interpretados como planícies de inundação arenosas, que embora não sejam exclusivas de sucessões pré-vegetação, ocorrendo até em ambientes modernos (e.g., Alexander \& Fielding, 2006), foram provavelmente mais 
comum antes do Siluriano. Esta hipótese pode explicar parte dos abundantes depósitos de arenitos em lençol (sheet-like sandstone) em sucessões fluviais pré-cambrianas e eopaleozoicas.

Dessa forma, os estudos apresentados nesta tese, vinculados ao mesmo objetivo de estudo das características e variedade de ambientes de planície de inundação antigas, revelam semelhanças entre as fácies sedimentares e geometria dos depósitos, também comparáveis a estudos anteriores encontrados na literatura especializada. Por outro lado, as particularidades contrastantes entre as unidades investigadas contribuem para a documentação da variedade de estilos de planície de inundação formadas anteriormente ao Siluriano, de maneira a acompanhar o recente esforço de reconhecimento da variedade de estilos deposicionais em depósitos fluviais pre-vegetação (e.g., Long, 2011).

O Grupo Santa Bárbara permite interpretações que contemplam não só as características de uma parte da planície aluvial, mas do sistema deposicional como um todo, superando possíveis dificuldades de interpretação que não poderiam ser sanadas sem que houvesse um contexto de ambiente deposicional, como enfatizado por North \& Davidson (2012). Neste contexto, foram determinados o posicionamento de associações de fácies que podem ser descritas como análogos a diques marginais, além de depósitos de canais de crevasse e de rompimento de diques marginais, que são posicionados lateralmente a depósitos de cinturão de canais, contribuindo para a construção de cristas aluviais, que se desenvolvem em proximidade aos depósitos de bacias de inundação.

O Grupo Guaritas, com exemplos da Formação Varzinha, estende as implicações do estudo Grupo Santa Bárbara, revelando em detalhe características da associação de arenitos tabulares ricos em FTSS. Nessa unidade, a paleogeografia diverge da apresentada no Grupo Santa Bárbara, uma vez que as fácies arenosas não são restritas a ambientes imediatamente vizinhos ao cinturão principal de canais, ocorrendo de maneira mais generalizada na planície de inundação. Interpretam-se mecanismos de transporte de carga de fundo que incluem pequenos canais (ribbon channels), possivelmente distributários, que adentram a planície, construindo sua própria crista aluvial, além de eventos de enchentes com capacidade de transporte suficiente para transportar e sedimentar carga de fundo em áreas distais da planície de inundação. A menor resistência ao fluxo promovida pela ausência de vegetação possivelmente contribuiu para a eficiência do segundo processo.

A Formação Tombador do Supergrupo Espinhaço, por sua vez, contém depósitos de planície de inundação mais arenosos, em um contínuo com os demais exemplos, pois embora não apresente uma associação de fácies de granulação fina, compatível com descrições de 
bacias de inundação, permite a correlação lateral de geometrias de depósitos sedimentares canalizados e não canalizados marginais aos canais.

Desta forma, os três exemplos estudados contribuem significativamente para a ampliação da escassa base de dados sedimentológicos sobre depósitos de planície de inundação pré-vegetação, e permitem a elaboração de um modelos de fácies específico para esse tipo de depósito, caracterizado por faixas, de largura variável, de depósitos arenosos de fluxo desconfinado nas margens dos cinturões de canais, que podem ser dominantes e contribuir significativamente para o caráter marcadamente arenoso das planícies de inundação. 


\section{Conclusão}

A influência da evolução das plantas terrestres nos estilos de sedimentação fluvial ao longo do tempo geológico é tema tradicional de investigação sedimentológica que tem recebido atenção renovada em anos recentes (Schumm, 1968; Cotter, 1978; Davies \& Gibling, 2010a; Long, 2011). A possibilidade de existência de um estilo particular de canais fluviais antes do Siluriano (Cotter, 1978) e a possível influência da evolução vegetal nos padrões de canais ao longo do Fanerozoico (Davies \& Gibling, 2010a) são os temas mais debatidos, revelando uma ênfase no estudo de ambientes de cinturão de canais. Apesar dessa tendência, os ambientes mais claramente afetados pela presença de vegetação em contextos modernos são as planícies de inundação, e sua ausência em sistemas anteriores ao Siluriano implica em condições hidrodinâmicas e padrões de preservação de depósitos sedimentares marcadamente diferentes das atuais. Essa constatação traz a necessidade de estudos desse tipo de depósito em unidades antigas e da elaboração de modelos de fácies específicos de forma a facilitar seu reconhecimento e interpretação. Apesar dessa clara importância, raros são os exemplos de depósitos de planícies de inundação precambrianos e eopaleozoicos descritos na bibliografia (Sønderholm \& Tirsgaard, 1998; Hadlari et al., 2006; Fralick \& Zaniewski, 2012).

A presente tese apresenta os resultados do estudo de três diferentes unidades portadoras de depósitos de planície de inundação fluvial anteriores à colonização dos ambientes continentais pela vegetação: o Grupo Santa Bárbara (Ediacarano, Bacia do Camaquã - RS), a Formação Varzinha do Grupo Guaritas (Cambriano da Bacia do Camaquã RS) e a Formação Tombador (Mesoproterozoico do Supergrupo Espinhaço - BA). As três unidades apresentam marcantes semelhanças em seus depósitos marginais aos canais fluviais, contribuindo para a elaboração de um modelo de fácies para este tipo de depósito, porém apresentando particularidades que enriquecem a documentação sobre a variabilidade de processos e produtos em sistemas fluviais pré-vegetação.

O Grupo Santa Bárbara compreende um ambiente aluvial formado por leques aluviais, cinturão de canais fluviais e planícies de inundação, que foi ativo ao longo da história de preenchimento da bacia. O cenário apresenta um cinturão de canais com arenitos conglomeráticos com fácies e geometria deposicional compatíveis com depósitos de rios com carga de fundo cascalhenta. Os depósitos de planície de inundação, formados pela intercalação de arenito e pelito, englobam depósitos interpretados como de bacia de inundação, formado pelos depósitos de granulação mais fina, e depósitos formados por fluxo trativo fora dos canais, que construíram ambientes análogos a diques marginais. As fácies 
estudadas compartilham de características com exemplos da bibliografia, como a abundância de depósitos arenosos e a preservação de estruturas sedimentares de pequena escala, embora a maior proporção de gretas de contração e intraclastos pelíticos e a formação de paleossolos contraste com os exemplos anteriormente descritos de planícies de inundação pré-vegetação. Entre as conclusões de maior importância do estudo está a proposta de um contexto específico para a associação de fácies de arenitos ricos em FTSS, em um ambiente lateral ao cinturão de canais, dominado por fluxo desconfinado dirigido às áreas rebaixadas da bacia de inundação.

Interações entre mais de um ambiente deposicional na planície aluvial, ainda que raramente documentadas em exemplos pré-silurianos, também ocorrem na bibliografia especializada, visto que ao menos em dois dos principais exemplos de depósitos reconhecidos como formados por sedimentação em planície de inundação antigas foram reconhecidos mais de um tipo de ambiente deposicional (Sønderholm \& Tirsgaard, 1998; Hadlari et al., 2006), reforçando o argumento de que associações de fácies por si só não são diagnósticas de ambientes deposicionais, sendo importante a identificação de contexto sedimentar.

O Grupo Guaritas apresenta também um registro de planície de inundação pré-vegetação, que de maneira análoga ao Grupo Santa Bárbara, ocorrem em associação com depósitos de outros ambientes da planície aluvial, notadamente cinturões de canais e leques aluviais próximos às margens da bacia. A planície aluvial interpretada é composta por sistema de canais entrelaçados, próximo da borda oeste da bacia, que eram bordejados por depósitos arenosos interpretados como análogos a diques marginais, construídos por fluxo não canalizado. Os depósitos distais da planície de inundação são interpretados como bacias de inundação, que por apresentarem feições de exposição subaérea e formação de perfis de paleossolo, podem ser entendidas como bem drenadas. Um aspecto notável deste sistema deposicional decorre do fato da carga de fundo arenosa ter alcançado porções distais da planície de inundação, transportadas por pequenos canais distributários, que construíram suas próprias cristas aluviais, aumentando assim a eficiência de transporte de carga de fundo para as partes mais distais da planície de inundação. Este ambiente deposicional, embora semelhante ao descrito no Grupo Santa Bárbara, apresenta uma proporção maior de depósitos arenosos.

Os depósitos de arenito em lençol (sheet-like sandstone) da Formação Tombador, Supergrupo Espinhaço, representam um tipo particular de planície de inundação, que de forma diversa dos depósitos mais novos do Ediacarano e Cambriano da Bacia do Camaquã, apresenta relação mais estreita com fácies identificadas como depósitos fluviais canalizados, indicando desenvolvimento de depósitos de planícies de inundação sobre barras ou complexo 
de barras aluviais inativas. Esse contexto não exclui a interpretação de planícies de inundação, porém neste caso representando um contínuo desde depósitos de topo de barras individuais até grandes áreas periodicamente inundadas, possivelmente sobre complexos de barras amalgamadas. Dessa forma, a descrição de geometria em afloramento de grande escala, que mostram ambientes canalizados e não canalizados relacionados, são fundamentais para a identificação destes ambientes sedimentares, com processos e depósitos sedimentares particulares, laterais a associação de fácies depositadas em canais fluviais. O estudo de caso da Formação Tombador, somados aos exemplos dos grupos Santa Bárbara e Guaritas, sugere a existência de um contínuo de proporção de arenitos e depósitos de granulação fina na planície de inundação, exemplificando uma variedade considerável de tipos de planícies de inundação pré-vegetação.

A combinação dos três exemplos indica que a existência de planícies de inundação em sucessões sedimentares pré-vegetação, como pode ser mais frequente do que o atualmente aceito. Planícies de inundação podem, de acordo com os exemplos estudados e exemplos da literatura, variar desde ritmitos, com ou sem feições indicativas de exposição subaérea, até depósitos formados quase que exclusivamente por arenitos. O reconhecimento desta variabilidade de estilos vai de encontro a propostas recentes (e.g., Long, 2011) que reconhecem a variabilidade de estilos fluviais em cinturões de canais desenvolvidos anteriormente a colonização do continente por plantas vasculares, e que expande a documentação da complexidade dos depósitos fluviais antigos para além dos conceitos simplistas de amplo predomínio de arenitos-em-lençól, sedimentação episódica e escassez de fácies de decantação nas planícies aluviais.

Futuros estudos sobre o tema se beneficiarão de uma abordagem que leve em conta relações espaciais entre diferentes associações de fácies, refletindo ambientes diversos da planície aluvial, em oposição às abordagens que enfatizam processos e produtos dos cinturões de canais e interpretam variações verticais como resultado exclusivo de modificações nos regimes de vazão ou controles externos, desconsiderando migrações laterais de ambientes dominados por processos diversos. O estudo de planícies de inundação e o detalhamento de seus processos e produtos, além da relação com outras partes dos sistemas aluviais, tem grande potencial para interpretações mais precisas sobre as condições climáticas durante o Precambriano a exemplo do que ocorre em depósitos fanerozoicos, e o estabelecimento de modelos de fácies para esse tipo de ambiente pode alterar significativamente nossa compreensão sobre os sistemas deposicionais continentais do Precambriano e Eopaleozoico. 


\section{Bibliografia}

Adams, P. N., Slingerland, R. L., \& Smith, N. D. (2004). Variations in natural levee morphology in anastomosed channel flood plain complexes. Geomorphology, 61(1-2): $127-142$.

Alexander, J., Fielding, C. R., \& Pocock, G. D. (1999). Flood behaviour of the Burdekin River, tropical north Queensland, Australia. Geological Society, London, Special Publications, 163(1): 27-40.

Alexander, J., \& Fielding, C. R. R. (2006). Coarse-grained floodplain deposits in the seasonal tropics: towards a better facies model. Journal of Sedimentary Research, 76(3-4): $539-556$.

Alexander, J., \& Marriott, S. B. (1999). Floodplains: Interdisciplinary Approaches. Geological Society of London Special Publications, 163: 1-13.

Allen, J. R. L. (1970). A quantitative model grain size and sedimentary structures in lateral deposits. Geological Journal, 7: 129-146.

Allen, J. R. L., \& Williams, B. P. J. (1982). The Architecture of an Alluvial Suite: Rocks Between the Townsend Tuff and Pickard Bay Tuff Beds (Early Devonian), Southwest Wales Philosophical Transactions of the Royal Society of London. Series B, Biological Sciences, The Royal Society, 297(1085): 51-89.

Allison, M. A. A., Kuehl, S. A. A., Martin, T. C. C., \& Hassan, A. (1998). Importance of flood-plain sedimentation for river sediment budgets and terrigenous input to the oceans: Insights from the Brahmaputra-Jamuna River. Geology, 26(2): 175-178.

Almeida, F. F. M. (1967). Origem e evolução da Plataforma Brasileira. Boletim Da Divisão de Geologia E Mineralogia DNPM, 241(241): 1-36.

Almeida, F. F. M. (1969). Diferenciação tectônica da Plataforma Brasileira. In: XXIII Congresso Brasileiro de Geologia, SBG, Salvador, Anais (Vol. 1, p. 29-46). Salvador.

Almeida, R. P. (2001). Evolução tectono-sedimentar da Formação Santa Bárbara na Sub-bacia Camaquã Ocidental, RS. Universidade de São Paulo, São Paulo.

Almeida, R. P. (2005). Tectônica e sedimentação do Ediacarano ao Ordoviciano: exemplos do Supergrupo Camaquã (RS) e do Grupo Caacupé (Paraguai Oriental). Universidade de São Paulo, São Paulo.

Almeida, R. P., Janikian, L., Fragoso-Cesar, A. R. S., \& Fambrini, G. L. (2010). The ediacaran to cambrian rift system of southeastern south america: Tectonic implications. Journal of Geology, 118(2): 145-161.

Almeida, R. P., Janikian, L., Fragoso-Cesar, A. R. S., \& Marconato, A. (2009). Evolution of a rift basin dominated by subaerial deposits: The Guaritas Rift, Early Cambrian, Southern Brazil. Sedimentary Geology,, 217(1-4): 30-51. 
Almeida, R. P., Santos, M. G. M., Fragoso-Cesar, A. R. S., Janikian, L., \& Fambrini, G. L. (2012). Recurring extensional and strike-slip tectonics after the Neoproterozoic collisional events in the southern Mantiqueira province. Anais Da Academia Brasileira de Ciências, 84: 347-376.

Álvaro, J. J. J., Van Vliet-Lanoë, B., Vennin, E., \& Blanc-Valleron, M. M. M.-M. (2003). Lower Cambrian paleosols from the Cantabrian Mountains (northern Spain): A comparison with Neogene-Quaternary estuarine analogues. Sedimentary Geology, 163(1-2): 67-84.

Aslan, A., \& Autin, W. J. (1999). Evolution of the Holocene Mississippi River floodplain, Ferriday, Louisiana; insights on the origin of fine-grained floodplains. Journal of Sedimentary Research, 69(4): 800-815.

Asselman, N. E. M. E. M., \& Middelkoop, H. (1995). Floodplain sedimentation: quantities, patterns and processes. Earth Surface Processes \& Landforms, 20(6): 481-499.

Babinski, M., Neves, B. B. B., \& Noce, C. M. (1994). Problemas da Metodologia U/Pb com Zircões de Vulcânicas Continentais: Caso do Grupo Rio dos Remédios Supergrupo Espinhaço, no Estado da Bahia. In: Congresso Brasileiro de Geologia 38, Balneário de Camboriú. Anais, $S B G$ (p. 409-410).

Babinski, M., Van Schmus, W. R., Chemale, F., \& Brito Neves, B. B. (1993). Idade isocrônica $\mathrm{Pb} / \mathrm{Pb}$ em rochas carbonáticas da Formação Caboclo em Morro do Chapéu, BA. In: Simpósio sobre o Cráton do São Francisco 2, Salvador, Anais. SBG/SGM BA/CNPq (p. 160-163).

Becker, R., \& Fernandes, L. A. D. (1982). Caracterização faciológica da sequência vulcano-sedimentar eo-paleozóica na Folha Passo do Tigre (RS). Acta Geologica Leopoldensia, 13(13): 287-322.

Bentham, P. A. A., Talling, P. J. J., \& Burbank, D. W. W. (1993). Braided stream and flood-plain deposition in a rapidly aggrading basin: the Escanilla Formation, Spanish Pyrenees. Braided Rivers, 75: 177-194.

Beukes, N. J. J., Dorland, H., Gutzmer, J., Nedachi, M., \& Ohmoto, H. (2002). Tropical laterites, life on land, and the history of atmospheric oxygen in the Paleoproterozoic. Geology, 30(6): 491-494.

Bomfim, L. F., Pedreira, A. J., \& Margalho, R. S. F. X. (1990). Geologia da Chapada Diamantina Oriental, Bahia (Folha Mucugê). In: Pedreira, A. J. \& Margalho, R. S. F. X. (EDS.), Programa de Levantamentos Geológicos Básicos do Brasil. Mucugê (Folha SD.24-V-C-II), Estado da Bahia; Texto Explicativo. (p. 25-73). Brasília: DNPM/CPRM.

Borba, A. W., Mizusaki, A. M. P., da Silva, D. R. A., Kawashita, K., Borba, A. W., \& Silva, D. R. A. (2003). Razões Isotópicas $87 \mathrm{Rb} / 86 \mathrm{Sr}, 87 \mathrm{Sr} / 86 \mathrm{Sr}$ e $143 \mathrm{Nd} / 144 \mathrm{Nd}$ como Traçadores de Proveniência de Rochas Sedimentares Siliciclásticas: Exemplos no Grupo Camaquã (Paleozóico inferior, RS, Brasil). Pesquisas Em Geociências, 30(2): 39-50.

Borba, A. W. W., \& Mizusaki, A. M. P. M. P. (2002). Significado tectônico dos depósitos de 
leques aluviais da Formação Santa Bárbara (Eo-Paleozóico) na região de Caçapava do Sul (RS, Brasil). Pesquisas Em Geociências, 29: 31-41.

Borba, A. W. W., \& Mizusaki, A. M. P. M. P. (2003). Santa Bárbara Formation (Caçapava do Sul, southern Brasil): depositional sequences and evolutin of an Early Paleozoic postcollisional basin. Journal of South American Earth Sciences, 16: 365-380.

Bown, T. M., \& Kraus, M. J. (1987). Integration of channel and floodplain suites. I. Developmental sequence and lateral relations of alluvial paleosols. Journal of Sedimentary Petrology, 57(4): 587-601.

Bridge, J. S. (1984). Large-scale facies sequences in alluvial overbank environments. Journal of Sedimentary Petrology, 54(2): 583-588.

Bridge, J. S. (1993). The interaction between channel geometry, water flow, sediment transport and deposition in braided rivers. Geological Society, London, Special Publications, 75(1): 13-71.

Bridge, J. S. (2003a). Rivers and Floodplains: forms, processes and sedimentary record (p. 491). Blackwell Publishing.

Bridge, J. S. (2003b). Rivers and Floodplains: forms, processess and sedimentary record. Blackwell Science Ltd.

Bridge, J. S., \& Demicco, R. V. (2008). Earth surface processes, landforms and sediment deposits (p. 832). New York: Cambridge University Press.

Brierley, G. J., Ferguson, R. J., \& Woolfe, K. J. (1997). What is a fluvial levee? Sedimentary Geology, 114(1-4): 1-9.

Bristow, C. S., Skelly, R. L., \& Ethridge, F. G. (1999). Crevasse splays from the rapidly aggrading, sand-bed, braided Niobrara River, Nebraska: Effect of base-level rise. Sedimentology, 46(6): 1029-1047.

Brito-Neves, B. B., Cordani, U. G., \& Torquato, J. R. F. (1980). Geologia e Recursos Minerais do Estado da Bahia. In: :INDA, H. A. V \& DuARTE, F. B. (EDS.), (Vol. v.1, p. p.1-101.). Secretaria de Minas do Estado da Bahia. Textos Básicos.

Carvalho, P. F. (1929). Reconhecimento geológico efectuado no munic'ipio de Caçapava, Rio Grande do Sul, Brasil. Boletim Do Serviço Geologico E Mineralogico Do Brasil, 41-55.

Carvalho, P. F. (1932). Reconhecimento Geológico no Estado do Rio Grande do Sul. Boletim Do Instituto Geológico E Mineralógico Brasileiro, 66: 1-72.

Cazanacli, D., \& Smith, N. D. (1998). A study of morphology and texture of natural leveesCumberland Marshes, Saskatchewan, Canada. Geomorphology, 25(1-2): 43-55.

Chemale Jr., F. (2002). Evolução Geológica do Escudo Sul-rio-grandense. In: Holz, M. \& DE Ros, L. F. (EDS.), Geologia do Rio Grande do Sul (p. 13-52). CIGO/UFRGS. 
Collinson, J. D. (1996). Alluvial Sediments. In: ReAdING, H. G. (ED.), Sedimentary environments, processes, facies and stratigraphy (2nd ed., p. 37-82). Oxford. Blackwell Science.

Costa, L. A. M., \& Inda, H. A. V. (1982). O Aulacógeno do Espinhaço. Ciências Da Terra, 2: $13-18$.

Cotter, E. (1978). The evolution of fluvial style, with special reference to the central Appalachian Palaeozoic. In: MiAll, A. D. (ED.), Fluvial Sedimentology (Vol. 5, p. 361-384).

Davies, N. S., \& Gibling, M. R. (2010a). Cambrian to Devonian evolution of alluvial systems: The sedimentological impact of the earliest land plants. Earth-Science Reviews, 98(3-4): 171-200.

Davies, N. S., \& Gibling, M. R. (2010b). Paleozoic vegetation and the Siluro-Devonian rise of fluvial lateral accretion sets. Geology, 38(1): 51-54.

Davies, N. S., \& Gibling, M. R. (2011). Evolution of fixed-channel alluvial plains in response to Carboniferous vegetation. Nature Geoscience, 4(9): 629-633.

Davies, N. S., Gibling, M. R., \& Rygel, M. C. (2011). Alluvial facies evolution during the Palaeozoic greening of the continents: Case studies, conceptual models and modern analogues. Sedimentology, 58(1): 220-258.

Derby, O. A. (1906). The geology of the diamond and carbonado washing of Bahia, Brazil. Econ.Geol, 1: 134-142.

De Ros, L. F., Morad, S., \& Paim, P. S. G. (1994). The role of detrital composition and climate on the diagenetic evolution of continental molasses: evidence from the Cambro--Ordovician guaritas sequence, southern Brazil. Sedimentary Geology, 92(3-4): $197-228$.

Dominguez, J. M. L. (1993). O Cráton do São Francisco. In: J.M.L.DomingUEZ \& A.MisI (EDS.), (p. 137-159). Salvador: SBG-SGM-CNPQ.

Driese, S. G., \& Foreman, J. L. (1992). Palaeopedology and palaeoclimate implications of Late Ordovician vertic paleosols, Juniata Formation, southern Appalachians. Journal of Sedimentary Petrology, 62: 71-83.

Driese, S. G., Medaris Jr., L. G., Ren, M., Runkel, A. C., \& Langford, R. P. (2007). Differentiating pedogenesis from diagenesis in early terrestrial paleoweathering surfaces formed on granitic composition parent materials. Journal of Geology, 115(4): 387-406.

Driese, S. G., Mora, C. I., Cotter, E., \& Foreman, J. L. (1992). Palaeopedology and stable isotope chemistry of Late Silurian vertic paleosols, Bloomsburg Formation, Central Pennsylvania. Journal of Sedimentary Petrology, 62: 825-841.

Eriksson, P. G., Bumby, A. J., Brümer, J. J., \& van der Neut, M. (2006). Precambrian fluvial deposits: Enigmatic palaeohydrological data from the c. 2-1.9 Ga Waterberg Group, 
South Africa. Sedimentary Geology, 190(1-4): 25-46.

Ethridge, F. G., Jackson, T. J., \& Youngberg, A. D. (1981). Floodbasin sequence of a fine grained meander belt subsystem the coal bearing lower Wasatch and upper Fort Union formations southern Powder River Basin wyoming. In: ETHRidGe, F. G. \& FLORES, R. M. (EDS.), Recent and nonmarine depositional environments: Models for exploration: Soc. Econ. Paleontologists and Mineralogists Spec. Pub. 31 (p. 191-209).

Faccini, U. F., Paim, P. S. G., \& Fragoso-Cesar, A. R. S. (1987). Análise faciológica das molassas brasilianas na região das Minas do Camaquã, Eo-paleozóico do RS. In: III Simpósio Sul-Brasileiro de Geologia (Vol. 1, p. 75-91). Curitiba, PR.

Fambrini, G. L. (1998). O Grupo Camaquã (Transição Proterozóico-Fanerozóico) na região das Minas do Camaquã, RS: análise estratigráfica de fácies, proveniência $e$ paleocorrentes. Instituto de Geociências -- Universidade de São Paulo, São Paulo, SP.

Fambrini, G. L. (2003). O Grupo Santa Bárbara (Neoproterozóico III) da Bacia do Camaquã, Rio Grande do Sul. Instituto de Geociências -- Universidade de São Paulo, São Paulo, SP.

Fambrini, G. L., Almeida, R. P., Fragoso-Cesar, A. R. S., \& Janikian, L. (2006). Estratigrafia e evolução paleogeográfica do Grupo Santa Bárbara (Ediacarano) na sub-bacia Camaquã Ocidental, Rio Grande do Sul, Brasil.No Title. Revista Brasileira de Geociências, 36(3): $550-565$.

Fambrini, G. L., Janikian, L., Almeida, R. P., \& Fragoso-Cesar, A. R. S. (2005). O Grupo Santa Bárbara (Neoproterozóico III) na sub-bacia Camaquã Central, RS: sistemas deposicionais, paleogeografia e implicações tectônicas. Revista Brasileira de Geociências, 35(227-238): 227-238.

Fambrini, G. L., Janikian, L., Almeida, R. P., \& Fragoso-Cesar, A. R. S. (2007). Evolução Estratigráfica e Paleogeográfica do Grupo Santa Bárbara na Sub-bacia Camaquã Central, RS. Geologia USP - Série Científica, 7: 1-24.

Fielding, C. R. (1986). Fluvial channel and overbank deposits from the Westphalian of the Durham coalfield, NE England. Sedimentology, 33(1): 119-140.

Fielding, C. R., Allen, J. P., Alexander, J., \& Gibling, M. G. (2009). Facies model for fluvial systems in the seasonal tropics and subtropics. Geology, 37(7): 623-626.

Fielding, C. R., Allen, J. P., Alexander, J., Gibling, M. R., Rygel, M. C., \& Calder, J. H. (2011). Fluvial systems and their deposits in hot, seasonal semiarid and subhumid settings: modern and ancient examples. In: DAVIDSON, S. K., LELEU, S., \& NORTH, C. P. (EDS.), From River to Rock Record: The Preservation of Fluvial Sediments and Their Subsequent Interpretation (p. 89-111). SEPM Special Publication 97.

Fragoso-Cesar, A. R. S. (1984). Evolução paleoambiental e tectônica da Bacia do Camaquã: uma introdução. Instituto de Geociências -- Universidade Federal do Rio Grande do Sul.

Fragoso-Cesar, A. R. S. (1991). Tectônica de Placas no Ciclo Brasiliano: as orogenias dos 
Cinturões Dom Feliciano e Ribeira no Rio Grande do Sul. Instituto de Geociências -Universidade de São Paulo, São Paulo.

Fragoso-Cesar, A. R. S., Faccini, U. F., Paim, P. S. G., Lavina, E. L., \& Altamirano, J. A. F. (1985). Revisão na estratigrafia das molassas do Ciclo Brasiliano no Rio Grande do Sul. In: II Simpósio Sul-Brasileiro de Geologia (p. 477-491). Florianópolis.

Fragoso-Cesar, A. R. S., Fambrini, G. L., Almeida, R. P., Pelosi, A. P. M. R., Janikian, L., Riccomini, C., ... Saes, G. S. (2000). The Camaquã extensional basin: Neoproterozoic to early Cambrian sequences in southernmost Brazil. Revista Brasileira de Geociências, 30(3): 438-441.

Fragoso-Cesar, A. R. S., Lavina, E. L., Paim, P. S. G., \& Faccini, U. F. (1984). A Antefossa Molássica do Cinturão Dom Feliciano no Escudo do Rio Grande do Sul. In: XXXIII Congresso Brasileiro de Geologia (Vol. 7, p. 3272-3283). Rio de Janeiro, RJ.

Fragoso-Cesar, A. R. S., Silva Filho, W. F., Fambrini, G. L., Machado, R., Riccomini, C., Almeida, R. P., ... Janikian, L. (1999). Significado tectônico do magmatismo Rodeio Velho no rift Guaritas (Eopaleozóico do Rio Grande do Sul, Brasil). In: I Simpósio sobre vulcanismo e ambientes associados (p. 16). Gramado, RS.

Fralick, P., \& Zaniewski, K. (2012). Sedimentology of a wet, pre-vegetation floodplain assemblage. Sedimentology, 59(3): 1030-1049.

Gersib, G. A., \& McCabe, P. J. (1981). Continental coal-bearing sediments of the Port Hood Formation ( Carboniferous), Cape Linzee, Nova Scotia, Canada. In: ETHRIDGE, F. G. \& FLORES, R. M. (EDS.), Recent and ancient nonmarine depositional environments: models for exploration (p. 95-108). SEPM Special Publication 31.

Godinho, L. P. S., Almeida, R. P., Marconato, A., Santos, M. G. M., \& Fragoso-Cesar, A. R. S. (2013). Análise de proveniência dos arenitos conglomeráticos do Grupo Guaritas (RS): implicações para o paleoclima e a paleogeografia da sub-bacia Camaquã Central no Eocambriano. Geologia USP. Série Cientifica, 13: 123-144.

Godinho, L. P. S., Almeida, R. P., Santos, M. G. M., Marconato, A., \& Fragoso-Cesar, A. R. S. (2013). Fácies sedimentares e elementos arquitetônicos das Formações Serra do Apertado e Pedra Pintada na Região das Minas do Camaquã - RS. Geologia USP. Série Cientifica, 13: 22-48.

Gomez, B., Mertes, L. A. K., Phillips, J. D., Magilligan, F. J., \& James, L. A. (1995). Sediment characteristics of an extreme flood: 1993 upper Mississippi River valley. Geology, 23(11): 963-966.

Goñi, J. C., Goso, H., \& Issler, R. S. (1962). Estratigrafia e Geologia Econômica do Pré-Cambriano e Eo-Paleozóico Uruguaio e Sul-Rio-Grandense. Avulso Da Escola de Geologia Da Universidade Do RGS, 3: 1-105.

Gresse, P. G., Chemale Jr., F., Silva, L. C., Walraven, F., \& Hartman, L. A. (1996). Late- to post-orogenic basins of the Pan-African-Brasiliano collision orogen in southern Africa and southern Brazil. Basin Research, 8: 157-171. 
Hadlari, T., Rainbird, R. H., \& Donaldson, J. A. (2006). Alluvial, eolian and lacustrine sedimentology of a Paleoproterozoic half-graben, Baker Lake Basin, Nunavut, Canada. Sedimentary Geology, 190: 47-70.

Hartmann, L., Schneider, J., \& McNaughton, N. (2008). Detrital Zircon U-Pb Age Data, and Precambrian Provenance of the Paleozoic Guaritas Formation, Southern Brazilian Shield. International Geology Review, 50(4): 364-374.

Hughes, D. A., \& Lewin, J. (1982). A small-scale flood plain. Sedimentology, 29(6): 891-895.

Inda, H. A. V., \& Barbosa, J. F. (1978). Texto explicativo para o Mapa Geológico do Estado da Bahia, Escala 1:1.000.000. (p. 137). Salvador, BA: CPM-SME BA/CBPM.

Janikian, L. (2004). Seqüências deposicionais e evolução paleoambiental do Grupo Bom Jardim e da Formação Acampamento Velho, Supergrupo Camaquã, Rio Grande do Sul. Instituto de Geociências - Universidade de São Paulo, São Paulo, SP.

Janikian, L., Almeida, R. P., Fragoso-Cesar, A. R. S., \& Fambrini, G. L. (2003). Redefinição do Grupo Bom Jardim (Neoproterozóico III) em sua área-tipo: litoestratigrafia, paleogeografia e significado tectônico das sucessões vulcano-sedimentares do Supergrupo Camaquã, RS. Revista Brasileira de Geociências, 33(4): 349-362.

Janikian, L., Almeida, R. P., Fragoso-Cesar, A. R. S., Martins, V. T. S., Dantas, E. L., Tohver, E., ... D'Agrella-Filho, M. S. (2012). Ages (U-Pb \{SHRIMP $\}$ and $\{$ LA $\}$ ICPMS) and stratigraphic evolution of the Neoproterozoic volcano-sedimentary successions from the extensional Camaquã Basin, Southern Brazil. Gondwana Research, 21(2-3): 466-482.

Janikian, L., Almeida, R. P., Trindade, R. I. F., Fragoso-cesar, A. R. S., D’Agrella-Filho, M. S., Dantas, E. L., \& Tohver, E. (2008). The continental record of Ediacaran volcano-sedimentary successions in southern Brazil and their global implications. Terra Nova, 20(4): 259-266.

Jardim de Sá, E. F. (1981). Chapada Diamantina e a Faixa Santo Onofre: um exemplo de tectônica intraplaca no Proterozóico Médio do Cráton São Francisco. In: INDA, H. A. V., MARINHO, M. M., \& DuARTE, F. B. (EDS.), Geologia e Recursos Minerais do Estado da Bahia: textos básicos. (4th ed., p. 111-120). Salvador, BA: SME/COM.

Jardim de Sá, E. F., Neves, B. B. B., McReath, I., \& Bartels, R. L. (1976). Geocronologia e modelo tectonomagmático da Chapada Diamantina e Espinhaço Setentrional, Bahia. In: Congresso Brasileiro de Geologia, 29, Ouro Preto, Anais (p. 205-227). Ouro Preto: Sociedade Brasileira de Geologia.

Justo, A. P. (2003). Controles tectônicos e influência do soerguimento do Alto de Caçapava do Sul na sedimentação do Grupo Santa Bárbara (Eopaleozóico, Bacia do Camaquã, $R S)$. São Paulo.

Justo, A. P., \& Almeida, R. P. (2004). Controles tectônicos e influência do soerguimento do Alto de Caçapava do Sul na sedimentação do Grupo Santa Bárbara (Eopaleozóico, Bacia do Camaquã). In: XLII Congresso Brasileiro de Geologia (Vol. CD-ROM, p. S02:348). 
Knight, D. W., \& Brown, F. A. (2001). Resistance studies of overbank flow in rivers with sediment using the flood channel facility. Journal of Hydraulic Research, 39(3): $283-301$.

Kraus, M. J. (1987). Integration of channel and floodplain suites, II. Vertical relations of alluvial paleosols. Journal of Sedimentary Petrology, 57(4): 602-612.

Lavina, E. L., Faccini, U. F., Paim, P. S. G., \& Fragoso-Cesar, A. R. S. (1985). Ambientes de sedimentação da Bacia do Camaquã, Eo-paleozóico do Rio Grande do Sul. Acta Geologica Leopoldensia, 21(9): 185-227.

Leinz, V. (1939). Problema geológico do Post-Arqueano no Rio Grande do Sul. Mineração E Metalurgia, 4: 203-206.

Leinz, V., Barbosa, A. F., \& Teixeira, G. A. (1941). Mapa Geológico Cacapava-Lavras. Boletim da Divisão de Produção Mineral da Secretaria de Agricultura, Industria e Commercio (Vol. 90, p. 1-39). Porto Alegre, RS.

Long, D. G. F. (1978). Proterozoic stream deposits: some problems of recognition and interpretation of ancient sandy fluvial systems. In: MiALl, A. D. (ED.), Miall, A.D. (Ed.), Fluvial Sedimentology. Can. Soc. Petrol. Geol., Calgary, Mem., vol. 5, pp. 313-342. (Vol. 5, p. 313-342). Calgary: Canadian Society Petroleum Geology.

Long, D. G. F. (2006). Architecture of pre-vegetation sandy-braided perennial and ephemeral river deposits in the Paleoproterozoic Athabasca Group, northern Saskatchewan, Canada as indicators of Precambrian fluvial style. Sedimentary Geology, 190(1-4): 71-95.

Long, D. G. F. (2011). Architecture and Depositional Style of Fluvial Systems before Land Plants: A Comparison of Precambrian, Early Paleozoic, and Modern River Deposits. In: DAVIDSON, S. K., S., L., \& NorTh, C. P. (EDS.), From river to rock record (Vol. 97, p. 37-62). SEPM Special Publication.

Lopes, R. C., Wildner, W., Sander, A., \& Camozzato, E. (1999). Alogrupo Guaritas: aspectos gerais e considerações sobre o posicionamento do vulcanismo Rodeio Velho (encerramento do Ciclo Brasiliano ou instalação da Bacia do Paraná?). In: I Simpósio sobre vulcanismo e ambientes associados (p. 17). Gramado -- RS.

Love, S. E., \& Williams, B. P. J. (2000). Sedimentology, cyclicity and floodplain architecture in the lower old red sandstone of SW wales. Geological Society Special Publication, (180): 371-388.

Machado, R., \& Sayeg, H. S. (1992). Aplicação da análise geométrica e cinemática nos falhamentos que condicionaram a bacia molássica do Arroio Boici, RS. In: I Workshop Sobre as Bacias Molássicas Brasilianas (p. 73-76). São Leopoldo, RS.

Marconato, A. (2010). A influência da evolução de altos estruturais em sucessões aluviais: exemplos do Ediacarano e do Cambriano da Bacia Camaquã (RS). Instituto de Geociências da Universidade de São Paulo.

Marconato, A., Almeida, R. P., Santos, M. G. M., Nóbrega, J. E. S., \& Souza, R. B. (2009). 
Alluvial-eolian interaction in a Cambrian rift margin: the Pedra das Torrinhas and Pedra Pintada formations (Guaritas Group, RS). Anais Da Academia Brasileira de Ciências, 81(4): 819-836.

Marriott, S. B., \& Wright, V. P. (2004). Mudrock deposition in an ancient dryland system: Moor Cliffs Formation, Lower Old Red Sandstone, southwest Wales, UK. Geological Journal, 39(3-4): 277-298.

Martins, A. A. M., Andrade Filho, E. L., Loureiro, H. S. C., Arcanjo, J. B. A., \& Guimarães, R. V. B. (2008). Geologia da Chapada Diamantina Ocidental (Projeto Ibitiara - Rio de Contas). (Série Arqu., p. 68). CBPM/CPRM.

Miall, A. D. (1978). Lithofacies types and vertical profile models in braided river deposits: a summary. Can.Soc.Petrol.Mem, 5: pp. 597-604.

Miall, A. D. (1990). Principles of sedimentary basin analysis (2nd ed., p. 668). Springer-Verlag, New-York.

Miall, A. D. (1996). The Geology of Fluvial Deposits: Sedimentary Facies, Basin Analysis and Petroleum Geology (p. 852). Springer. Berlin.

Miall, A. D. (2000). Principles of Sedimentary Basin Analysis (3rd ed., p. 616). New York: Springer-Verlag.

Miall, A. D. (2014). Fluvial Depositional Systems. Cham: Springer International Publishing.

Middelkoop, H., \& Asselman, N. E. M. (1998). Spatial variability of floodplain sedimentation at the event scale in the Rhine-Meuse Delta, the Netherlands. Earth Surface Processes and Landforms, 23(6): 561-573.

Mitchell, R. L., \& Sheldon, N. D. (2009). Weathering and paleosol formation in the $1.1 \mathrm{Ga}$ Keweenawan Rift. Precambrian Research, 168(3-4): 271-283.

Muller, R., Nystuen, J. P., Wright, V. P., \& Müller, R. (2004). Pedogenic Mud Aggregates and Paleosol Development in Ancient Dryland River Systems: Criteria for Interpreting Alluvial Mudrock Origin and Floodplain Dynamics. Journal of Sedimentary Research, 74(4): 537-551.

Myers, W. R. C., Lyness, J. F., \& Cassells, J. (2001). Influence of boundary roughness on velocity and discharge in compound river channels [Influence de la rugosit $\tilde{A} \subset$ des

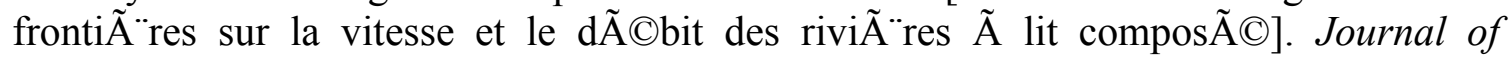
Hydraulic Research, 39(3): 311-319.

Naish, C., \& Sellin, R. H. J. (1996). Flow structure in a large-scale model of a doubly meandering compound channel. In: Ashworth, P. J., BennetT, S. J., Best, J. L., \& McLeland, S. J. (EDS.), Coherent Flow Strucutres in Open Channels. (p. 631-634). Willey.

Nanson, G. C., \& Croke, J. C. (1992). A genetic classification of floodplains. In: Brakenridge, G. R. \& Hagedorn, J. (EdS.), Floodplain Evolution (Vol. 4, p. 
459-486). Geomorphology.

Nedachi, Y., Nedachi, M., Bennett, G., \& Ohmoto, H. (2005). Geochemistry and mineralogy of the 2.45 Ga Pronto paleosols, Ontario, Canada. Chemical Geology, 214(1-2): 21-44.

Nicholas, A. P., \& Mclelland, S. J. (1999). Hydrodynamics of a floodplain recirculation zone investigated by field monitoring and numerical simulation. Geological Society Special Publication, (163): 15-26.

Nóbrega, J. E. S., Sawakuchi, A. O., \& Almeida, R. P. (2008). Minerais pesados das porções média e superior do Grupo Guaritas (Eocambriano, RS): considerações sobre a proveniência sedimentar. Revista Brasileira de Geociências., 38(3): 554-565.

North, C. P., \& Davidson, S. K. (2012). Unconfined alluvial flow processes: Recognition and interpretation of their deposits, and the significance for palaeogeographic reconstruction. Earth-Science Reviews, 111(1-2): 199-223.

O’Brien, P. E., \& Wells, A. T. (1986). A small, alluvial crevasse splay. Journal of Sedimentary Research, 56(6): 876-879.

Oliveira, C. H. E., Junior, F. C., Jelinek, A. R., Bicca, M. M., \& Philipp, R. P. (2014). U-Pb and $\mathrm{Lu}-\mathrm{Hf}$ isotopes applied to the evolution of the late to post-orogenic transtensional basins of the dom feliciano belt, Brazil. Precambrian Research, 246: 240-255.

Oliveira, J. M. M. T., \& Fernandes, L. A. D. (1991). Estágios finais da evolução do Cinturão Dom Feliciano: Tectônica e sedimentação da Formação Arroio dos Nobres. In: III Simpósio Nacional de Estudos Tectônicos (p. 58-59). Rio Claro, SP.

Oliveira, J. M. M. T., \& Fernandes, L. A. D. (1992). Bacias molássicas brasilianas, mito ou realidade? In: I Workshop Sobre as Bacias Molássicas Brasilianas (p. 97-105). São Leopoldo, RS.

Orton, G. J., \& Reading, H. G. (1993). Variability of deltaic processes in terms of sediment supply, with particular emphasis on grain size. Sedimentology, 40(3): 475-512.

Otero, E. P., Dominguez, J. M. L., \& Lima, C. . (1989). Sedimentação fluvio-eólica no Proterozóico Médio, Formação Tombador, Grupo Chapada Diamantina, Estado da Bahia. In: Simpósio de Geologia 1, Belo Horizonte, Anais. (p. 212-217.). Belo Horizonte: SBG, Boletim 10.

Paim, P. S. G. (1994). Depositional Systems and Paleogeographical Evolution of the Camaquã and Santa Bárbara Basins, Brazil. Oxford.

Paim, P. S. G. (1995). Fluvial palaeogeography of the Guaritas depositional sequence of southern Brazil. In: Plint, A. G. (ED.), Sedimentary Facies Analysis (Vol. 22, p. 3-16).

Paim, P. S. G. (1996). O sistema desértico úmido Pedra Pintada (cambro-ordoviciano do RS). In: XXXIX Congresso Brasileiro de Geologia (Vol. 2, p. 207-209). Salvador, BA.

Paim, P. S. G., Chemale Jr., F., \& Lopes, R. C. (2002). A Bacia do Camaquã. In: HolTZ, M. \& 
DeRos, L. F. (EDS.), Geologia do Rio Grande do Sul (p. 231-274). CIGO/UFRGS.

Paim, P. S. G., Faccini, U. F., Netto, R. G., \& Nowatzki, C. H. (1992). Estratigrafia de seqüências e sistemas deposicionais das bacias do Camaquã e Santa Bárbara, Eopaleozóico do RS (Brasil). Serie Correlación Geologica - Universidad Nacional de Tucumán, 9: 41-45.

Paim, P. S. G., Lopes, R. C., \& Chemale Jr., F. (1995). Aloestratigrafia, sistemas deposicionais e evolução paleogeográfica da Bacia do Camaquã -Vendiano Superior \Ordoviciano Inferior do RS. In: VI Simpósio Sul-Brasileiro de Geologia \I Encontro Geologia do Cone Sul (p. 39-50). Porto Alegre, RS.

Paim, P. S. G., \& Scherer, C. M. S. (2003). Arquitetura estratigráfica de sucessões flúvio-eólicas: o exemplo do Alogrupo Guaritas na região da Pedra Pintada, Rio Grande do Sul, Brasil. In: PAim, P. S. G., FAccini, U. F., \& NetTo, R. G. (EDS.), Geometria, arquitetura e heterogeneidades de corpos sedimentares -- Estudo de casos (p. 38-58). Unisinos.

Paim, P. S. G., \& Scherer, C. M. S. (2007). High-resolution stratigraphy and depositional model of wind- and water-laid deposits in the ordovician Guaritas rift (Southernmost Brazil). Sedimentary Geology, 202(4): 776-795.

Pedreira, A. . (1997). Sistemas Deposicionais da Chapada Diamantina Centro-oriental, Bahia. Revista Brasileira de Geociências, 27: 229-240.

Pedreira, A. J. (1988). Sequências deposicionais no Precambriano: Exemplo da Chapada Diamantina Oriental. In: Congresso Brasileiro de Geologia 35 (p. 648-659). Belém: Anais. SBG, 2.

Pedreira, A. J., \& Margalho, R. S. F. X. (1990). Geologia da Chapada Diamantina Oriental, Bahia (Folha Mucuge). In: Pedreira, A. J. \& Margalho, R. S. F. X. (EdS.), Programa de Levantamentos Geológicos Básicos do Brasil. Mucuge (Folha SD.24-V-C-II) Estado da Bahia, Texto Explicativo. (p. 19-68). Brasília: DNPM/CPRM.

Reading, H. G. (1986). Facies. In: READING, H. G. (ED.), Sedimentary Environments and Facies (2nd ed., p. 4-19).

Retallack, G. J. (1986). Fossil soils as grounds for interpreting long-term controls on ancient rivers. Journal of Sedimentary Research, 56(1): 1-18.

Retallack, G. J. (1992). How to find a Precambrian paleosol. In: SCHIDLOWSKI, M., GolubiC, S., Kimberley, M. M., McKirdy, D. M., \& Trudinger, P. A. (EdS.), Early Organic Evolution and Mineral and Energy Resources (p. 16-30). Springer Verlag.

Retallack, G. J. (2001). Soils of the past: an introduction to paleopedology. Blackwell Science Ltd.

Retallack, G. J. (2008). Cambrian paleosols and landscapes of South Australia. Australian Journal of Earth Sciences, 55: 1083-1106. 
Retallack, G. J. (2009). Cambrian, Ordovician and Silurian pedostratigraphy and global events in Australia. Australian Journal of Earth Sciences, 56(4): 571-586.

Retallack, G. J. (2011). Neoproterozoic loess and limits to snowball earth. Journal of the Geological Society, 168(2): 289-307.

Retallack, G. J. (2012). Were Ediacaran siliciclastics of South Australia coastal or deep marine? Sedimentology, 59(4): 1208-1236.

Retallack, G. J., \& Krinsley, D. H. (1993). Metamorphic alteration of a Precambrian (2.2 Ga) paleosol from South Africa revealed by backscattered electron imaging. Precambrian Research, 63(1-2): 27-41.

Retallack, G. J., \& Mindszenty, A. (1994). Well preserved late Precambrian paleosols from northwest Scotland. Journal of Sedimentary Research A: Sedimentary Petrology \& Processes, 64 A(2): 264-281.

Ribeiro, M. (1970). Geologia da Folha de Bom Jardim, Rio Grande do Sul, Brasil. Boletim Da Divisão de Geologia E Mineralogia - DNPM, 247: 1-142.

Ribeiro, M., Bocchi, P. R., Figueiredo Filho, P. M., \& Tessari, R. I. (1966). Geologia da Quadrícula de Caçapava do Sul, Rio Grande do Sul. Rio de Janeiro, RJ.

Ribeiro, M., \& Fantinel, L. M. (1978). Associações petrotectônicas do Escudo Sul-Riograndense: I Tabulação e distribuição das associações petrotectônicas do Escudo do Rio Grande do Sul. Ihner' $\{i\} n g i a$, Série Geologia, 5: 19-54.

Ribeiro, M., \& Lichtenberg, E. (1978). Síntese da Geologia do Rio Grande do Sul. In: XXX Congresso Brasileiro de Geologia (Vol. 6, p. 2451-2463). Recife, PE.

Robertson, J. F. (1966). Revision of Stratigraphy and nomenclature of rock units in Caçapava-Lavras Region. Notas E Estudos, IG-UFRGS, 1(2): 41-54.

Santos, M. G. M., Almeida, R. P., Godinho, L. P. S., Marconato, A., \& Mountney, N. P. (2014). Distinct styles of fluvial deposition in a Cambrian rift basin. Sedimentology, 61(4): 881-914.

Santos, M. G. M., Almeida, R. P., Mountney, N. P., \& Fragoso-Cesar, A. R. S. (2012). Seismites as a tool in the palaeoenvironmental reconstruction of fluvial deposits: The Cambrian Guarda Velha Formation, southern Brazil. Sedimentary Geology, 277-278: $52-60$.

Scherer, C. M. S., Paim, P. S. G., \& Melo, M. A. (2003). Estratigrafia de alta resolução em sucessões flúvio-eólicas: o exemplo do Alogrupo Guaritas (Bacia do Camaquã) na localidade da Pedra Pintada, Rio Grande do Sul, Brasil. In: I Encontro sobre a estratigrafia do Rio Grande do Sul: Escudo e Bacias (p. 99-103). Porto Alegre, RS.

Schmnudde, T. H. (1968). Floodplains. In: FAIRBRIDGE, R. W. (ED.), The Encylopedia of GeomorphoIogy. (p. 359-362). New York: Reinhold Book Corporation. 
Schobbenhaus, C. (1996). As tafrogêneses superpostas Espinhaço e Santo Onofre, Estado da Bahia: revisão e novas propostas. Revista Brasileira de Geociências, 26: 265-276.

Schobbenhaus, C., Hoppe, A., \& Baumann, A. (1994). Idade U/Pb do vulcanismo Rio dos Remédios, Chapada Diamantina, Bahia. In: Congresso Brasileiro de Geologia, 38. (p. 397-398). Balneário Camboriú.: Boletim de Resumos Expandidos, 2.

Schobbenhaus, C., \& Kaul, P. F. T. (1971). Contribuição à estratigrafia da Chapada Diamantina, Bahia Central. Mineração E Metalurgia, 53(315): 116-120.

Schumm, S. A. (1968). Speculations concerning the palaeo-hydraulic controls of terrestrial sedimentation. Geological Society of America Bulletin, 79: 1573-1588.

Smith, N. D., Cross, T. A., Dufficy, J. P., \& Clough, S. R. (1989). Anatomy of an avulsion. Sedimentology, 36(1): 1-23.

Smith, N. D., \& Perez-Arlucea, M. (1994). Fine-grained splay deposition in the avulsion belt of the lower Saskatchewan River, Canada. Journal of Sedimentary Research B: Stratigraphy \& Global Studies, 64(2): 159-168.

Sønderholm, M., \& Tirsgaard, H. (1998). Proterozoic fluvial styles: response to changes in accommodation space (Rivieradal sandstones, eastern North Greenland). Sedimentary Geology, 120(1-4): 257-274.

Teixeira, A. L., Gaucher, C., Paim, P. S. G., Fonseca, M. M., Parente, C. V, Silva Filho, W. F., \& Almeida, A. R. (2004). Bacias do Estágio da Transição da Plataforma Sul-Americana. In: Mantesso Neto, V., Bartorelli, A., Carneiro, C. D. R., \& Brito Neves, B. B. (EDS.), Geologia do Continente Sul-Americano: Evolução da Obra de Fernando Flávio Marques de Almeida (p. 487-537). Beca.

Tessari, R. I., \& Picada, R. (1966). Geologia da Quadrícula Encruzilhada do Sul, RS. Boletim Da Divisão de Fomento E Produção Mineral, 124: 1-122.

Tooth, S. (2000). Process, form and change in dryland rivers: a review of recent research. Earth-Science Reviews, 51: 67-107.

Tooth, S., Jansen, J. D., Nanson, G. C., Coulthard, T. J., \& Pietsch, T. (2008). Riparian vegetation and the late Holocene development of an anabranching river: Magela Creek, northern Australia. Bulletin of the Geological Society of America, 120(7-8): 1021-1035.

Tornqvist, T. E. (1993). Holocene alternation of meandering and anastomosing fluvial systems in the Rhine-Meuse Delta (central Netherlands) controlled by sea- level rise and subsoil erodibility. Journal of Sedimentary Petrology, 63(4): 683-693.

Valentine, E. M., Benson, I. A., Nalluri, C., \& Bathurst, J. C. (2001). Regime theory and the stability of straight channels with bankfull and overbank flow [La th $\tilde{A} \odot$ orie de rÃ@gime et la stabilit $\tilde{A} \subseteq$ des chenaux droits sous les conditions des $\tilde{A} @$ coulements $\tilde{A}$ ras bord et dÃ@bordÃ̄os]. Journal of Hydraulic Research, 39(3): 259-268. 
R. G. \& James, N. P. (EDS.), Facies Models and Response to Sea-level Change (p. 1-14). Geological Association of Canada.

Walker, R. G. (2006). Introduction. In: Posamantier, H. W. \& Walker, H. G. (Eds.), Facies Models Revisited. (p. 5-22). SEPM Special Publication 84.

Walling, D. E., \& He, Q. (1998). The spatial variability of overbank sedimentation on river floodplains. Geomorphology, 24(2-3): 209-223.

Wilson, A., Flint, S., Payenberg, T., Tohver, E., \& Lanci, L. (2014). Architectural Styles and Sedimentology of the Fluvial Lower Beaufort Group, Karoo Basin, South Africa. Journal of Sedimentary Research, 84(4): 326-348.

Wormleaton, P. R. (1996). Floodplain secondary circulation as a mechanism for flow and shear stress redistribution in straight compound channels. In: ASHWORTH, P. J., Bennett, S. J., Best, J. L., \& McLeland, S. J. (EDS.), Coherent Flow Strucutres in Open Channels. (p. 581-608.). Willey.

Wright, V. P., \& Marriott, S. B. (2007). The dangers of taking mud for granted: Lessons from Lower Old Red Sandstone dryland river systems of South Wales. Sedimentary Geology, 195(1-2): 91-100. 